University of Nebraska - Lincoln DigitalCommons@University of Nebraska - Lincoln

JFSP Synthesis Reports

U.S. Joint Fire Science Program

2009

\title{
A Synthesis of Post-Fire Road Treatments for BAER Teams: Methods, Treatment Effectiveness, and Decisionmaking Tools for Rehabilitation
}

Randy B. Foltz

Rocky Mountain Research Station's Soil

Peter R. Robiohaud

Rocky Mountain Research Station's Soil

Hakjun Rhee

Washington State University

Follow this and additional works at: http://digitalcommons.unl.edu/jfspsynthesis

Part of the Forest Management Commons, Other Forestry and Forest Sciences Commons, and the Wood Science and Pulp, Paper Technology Commons

Foltz, Randy B.; Robiohaud, Peter R.; and Rhee, Hakjun, "A Synthesis of Post-Fire Road Treatments for BAER Teams: Methods, Treatment Effectiveness, and Decisionmaking Tools for Rehabilitation" (2009). JFSP Synthesis Reports. 15.

http://digitalcommons.unl.edu/jfspsynthesis/15

This Article is brought to you for free and open access by the U.S. Joint Fire Science Program at DigitalCommons@University of Nebraska - Lincoln. It has been accepted for inclusion in JFSP Synthesis Reports by an authorized administrator of DigitalCommons@University of Nebraska - Lincoln. 
United States

Department of

Agriculture

Forest Service

(4is)

Rocky Mountain

Research Station

General Technical

Report RMRS-GTR-228
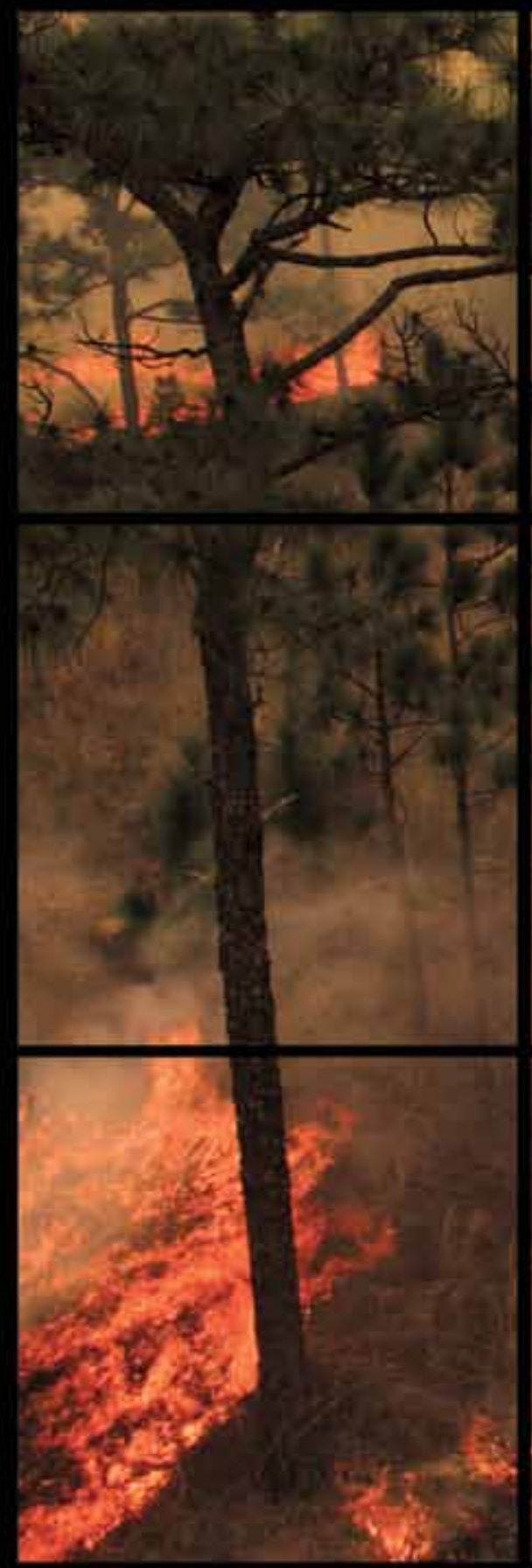

Randy B. Foltz, Peter R. Robichaud, and Hakjun Rhee
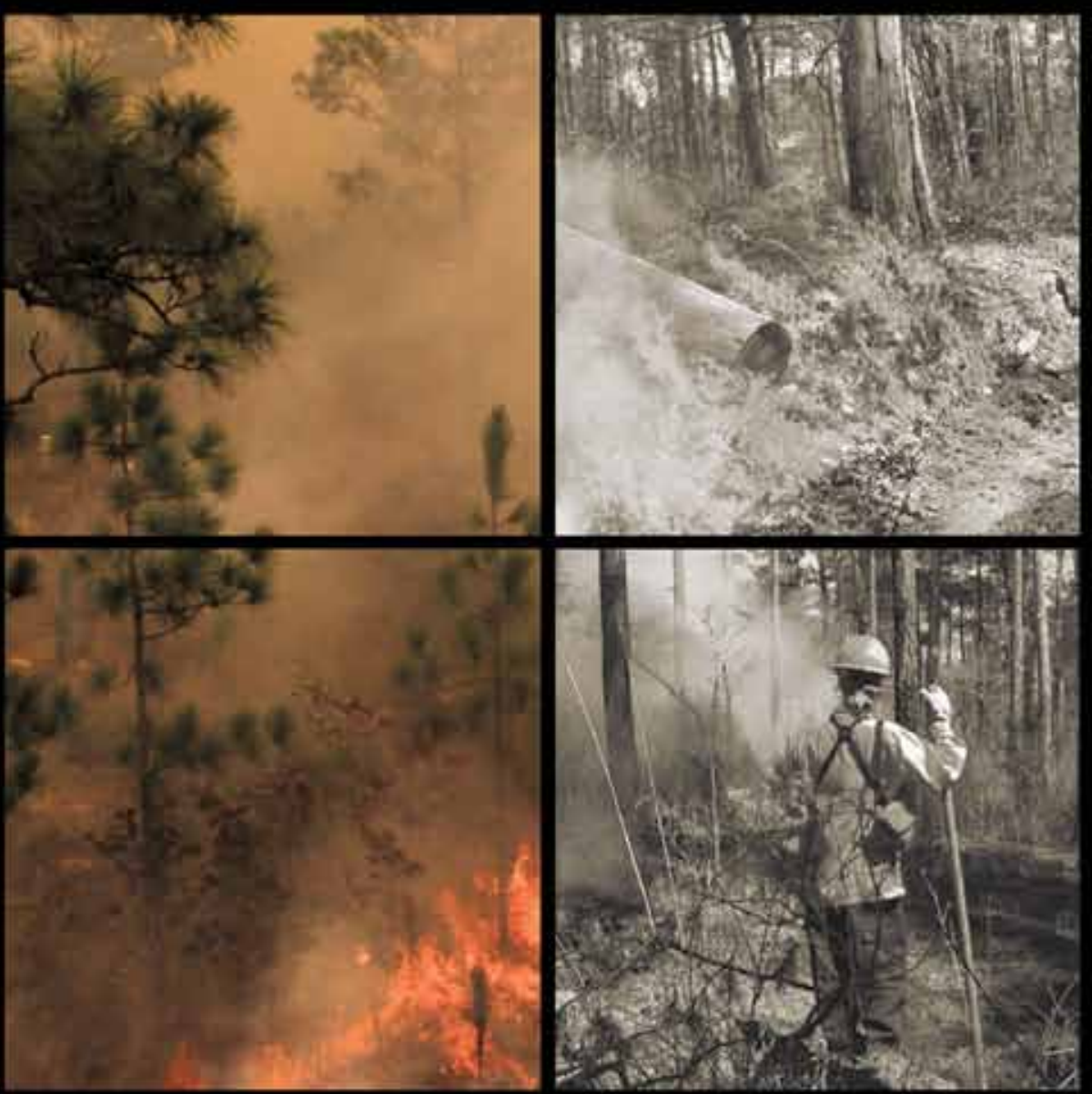

A SUMMARY OF

KNOWLEDGE FROM THE loint

Fire Science Prograili

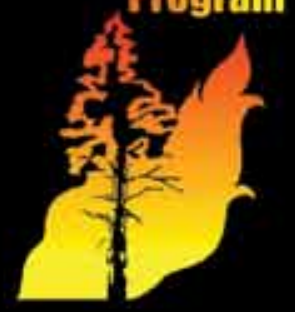


Foltz, Randy B.; Robichaud, Peter R.; Rhee, Hakjun. 2009. A synthesis of postfire road treatments for BAER teams: methods, treatment effectiveness, and decisionmaking tools for rehabilitation. Gen. Tech. Rep. RMRS-GTR-228 Fort Collins, CO: U.S. Department of Agriculture, Forest Service, Rocky Mountain Research Station. 152 p.

\section{AbStract}

We synthesized post-fire road treatment information to assist BAER specialists in making road rehabilitation decisions. We developed a questionnaire; conducted 30 interviews of BAER team engineers and hydrologists; acquired and analyzed gray literature and other relevant publications; and reviewed road rehabilitation procedures and analysis tools. Post-fire road treatments are implemented if the values at risk warrant the treatment and based on regional characteristics, including the timing of first damaging storm and window of implementation. Post-fire peak flow estimation is important when selecting road treatments. Interview results indicate that USGS methods are used for larger watersheds $\left(>5 \mathrm{mi}^{2}\right)$ and NRCS Curve Number methods are used for smaller watersheds $\left(<5 \mathrm{mi}^{2}\right)$. These methods are not parameterized and validated for post-fire conditions. Many BAER team members used their own rules to determine parameter values for USGS regression and NRCS CN methods; therefore, there is no consistent way to estimate postfire peak flow. Many BAER road treatments for individual stream crossings were prescribed based on road/culvert surveys, without considering capacities of existing road structure and increased post-fire peak flow. For all regions, rolling dips/water bars, culvert upgrading, and ditch cleaning/armoring are the most frequently used road treatments. For Forest Service Regions 1 and 4, culvert upgrading is preferred, especially for fish-bearing streams. For Forest Service Region 3, culvert removal with temporary road closure and warning signs is preferred. Except for culverts, insufficient data is available on other road treatments to estimate their capacity and to evaluate their effectiveness.

Keywords: wildfire, BEAR, burned area, emergency response, peak flow, roads

\section{The Authors}

Randy B. Foltz is a Research Engineer with the Rocky Mountain Research Station's Soil and Water Engineering Research Work Unit and is stationed at the Forestry Sciences Laboratory, Moscow, ID.

Peter R. Robichaud is a Research Engineer with the Rocky Mountain Research Station's Soil and Water Engineering Research Work Unit and is stationed at the Forestry Sciences Laboratory, Moscow, ID.

Hakjun Rhee is a Post-Doctoral Research Associate with the Biological Systems Engineering at Washington State University, Pullman, WA.

You may order additional copies of this publication by sending your mailing information in label form through one of the following media.

Please specify the publication title and series number.

\section{Fort Collins Service Center}

Telephone (970) 498-1392

FAX (970) 498-1122

E-mailrschneider@fs.fed.us

Web site http://www.fs.fed.us/rm/publications

Mailing address Publications Distribution

Rocky Mountain Research Station

240 West Prospect Road

Fort Collins, CO 80526

Rocky Mountain Research Station

240 W. Prospect Road

Fort Collins, Colorado 80526 


\section{ACKNOWLEDGMENTS}

Funding for the project was provided by the Joint Fire Science Program (project number 06-3-4-03). We gratefully acknowledge the contributions of the following Forest Service BAER team members for their interviews: Norman Ambos, Melvin Bennett, Greg Bevenger, Mike Bradshaw, Thomas Clifford, Mike Dixon, Thomas Durston, Richard Edwards, Robert Faust, Nick Gerhardt, Terry Hardy, Ben Hipple, Alex Janicki, Richard Jones, Greg Kuyumjian, John Lane, Rusty LeBlanc, Robert Lefevre, Grant Loomis, Gary Miller, Carolyn Napper, Gregory Napper, Kathy Nelson, Mark Nienow, Mike Parenti, Rick Patten, Dean Sirucek, Mark Story, Bo Stuart, and John Thornton. We also acknowledge the contributions of the following personnel for their review of this report: Greg Bevenger, Nick Gerhardt, Richard Hawkins, Greg Kuyumjian, and Bruce Sims. 


\section{Contents}

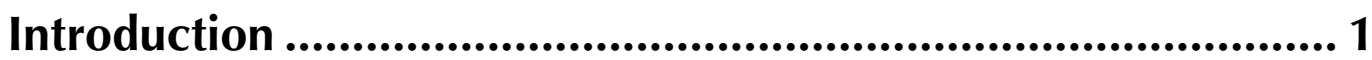

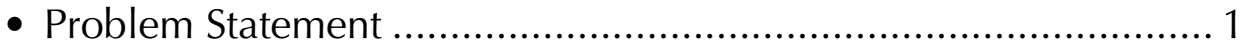

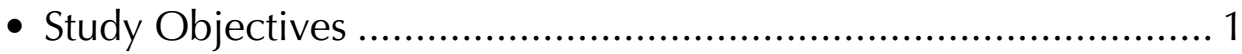

Methods ............................................................................... 3

- Burned Area Report Data............................................................. 3

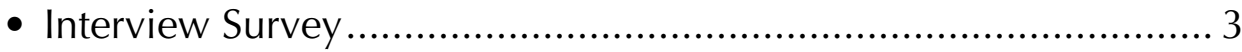

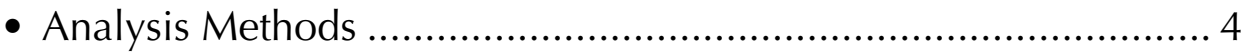

Results and Discussion .................................................... 5

- Overview of Data Collected ........................................................ 5

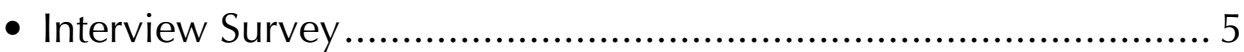

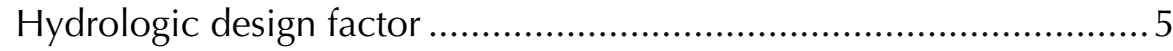

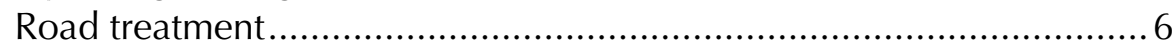

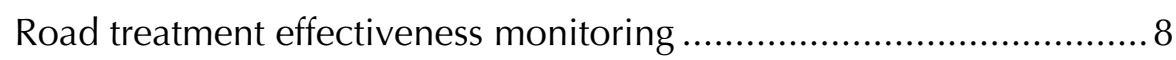

- Post-Fire Road Rehabilitation Procedures ..................................... 8

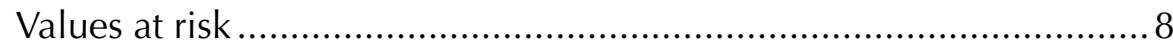

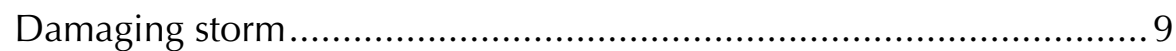

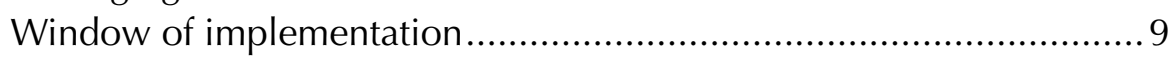

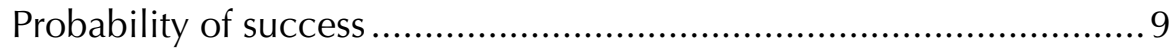

Post-fire runoff increase................................................................. 10

Capacity of existing road structures ................................................. 10

Choosing a road treatment ........................................................... 11

- Post-Fire Runoff and Erosion Estimation ....................................... 11

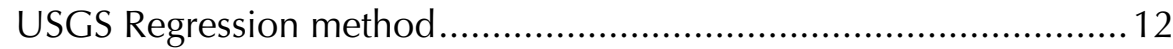

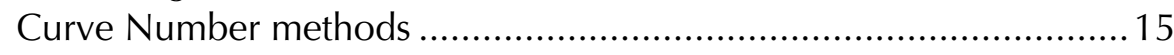

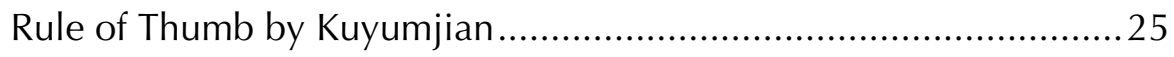

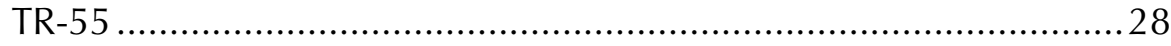

Water Erosion Prediction Project (WEPP) Model: Erosion Risk

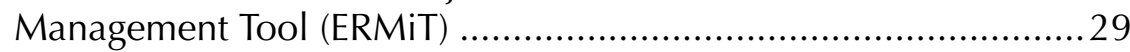

Fire-Enhanced Runoff and Gully Initiation (FERGI) model .................34

Watershed Response Model for Forest Management (WATBAL) .........37

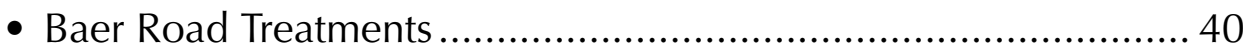

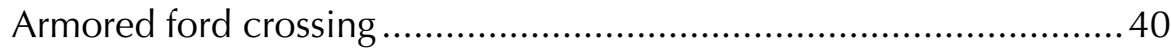

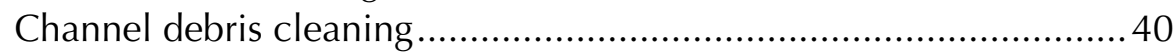

Culvert inlet/outlet armoring/modification ........................................40

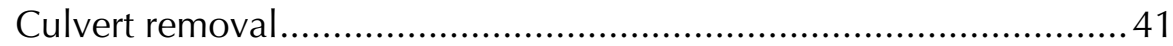

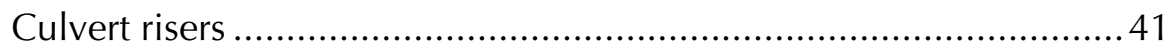

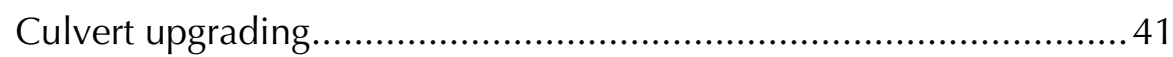

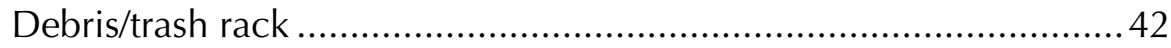

Ditch cleaning/armoring................................................................. 42

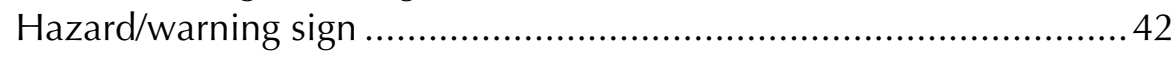

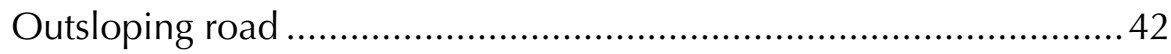




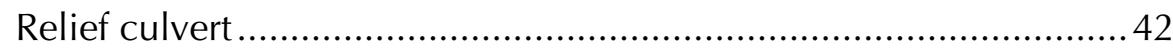

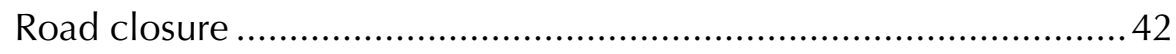

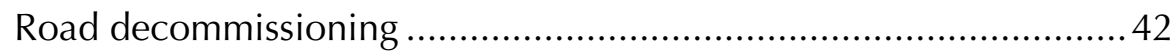

Rolling dip/water bar.............................................................. 43

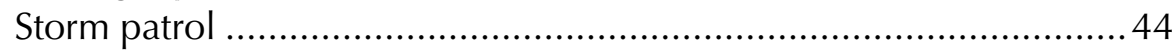

- Gray Literature From BAER Interviews .................................... 44

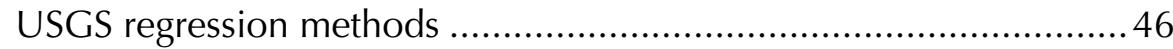

Curve Number methods .......................................................... 53

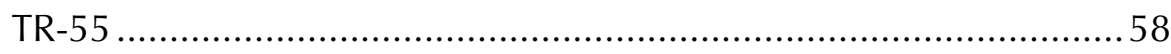

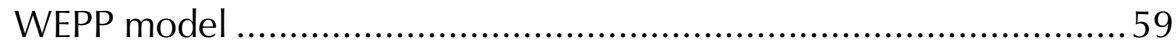

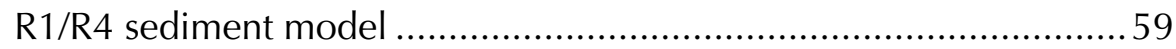

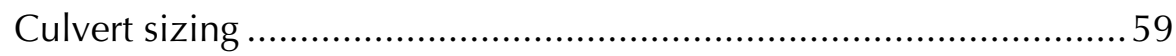

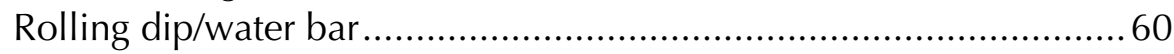

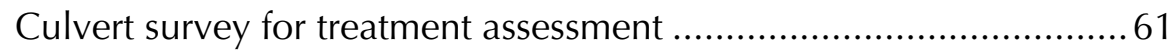

Evaluation of road treatment implementation ..................................62

- Summary of Gray Literature on BAER Road Treatments.............. 65

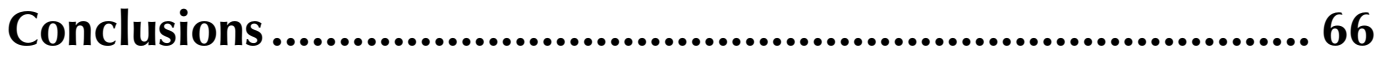

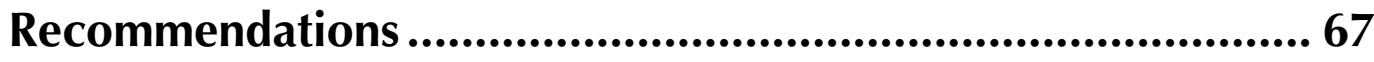

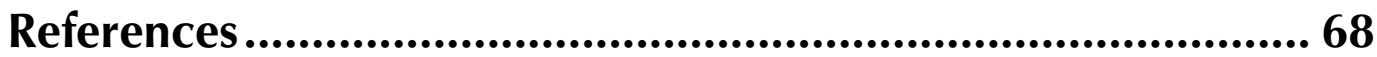

Appendix A-Example Data and Interview Forms.................... 75

Appendix B-List of Gray Literature from BAER Interviews .... 79

Appendix C-USGS Regression Methods .................................. 84

Appendix D—NRCS Curve Number Method ............................ 142 



\section{Introduction}

Wildland fires can cause extreme changes in the landscape that can drastically influence surface runoff and sediment transportation. Removal of the forest duff layer causes increased runoff and subsequent increases in peak flow and sediment transport. These increased flows can impact forest resources and infrastructures. Roads are one of the most impacted forest infrastructures. They are designed to divert water to desired locations and prevent washouts. Post-fire flows often exceed design capacity, requiring that many structures be treated following fires. For example, culverts sized for unburned forest conditions are often unable to pass the new, higher flows and are replaced with larger ones. Nationwide road structure replacement costs in the 1990s were about 20 percent of the total post-fire rehabilitation expense (Robichaud and others 2000).

\section{Problem Statement}

Watersheds with satisfactory hydrologic conditions (greater than $75 \%$ of the ground covered with vegetation and litter) and adequate rainfall sustain stream baseflow conditions for much or all of the year and produce little sediment and erosion. Fire consumes accumulated forest floor material and vegetation, altering infiltration by exposing soils to raindrop impact or creating water repellent soil conditions, thus reducing soil moisture content. Runoff plot studies show that, when severe fire produces hydrologic conditions that are poor (less than $10 \%$ of the ground surface covered with plants and litter), surface runoff can increase more than $70 \%$ and erosion can increase by three orders of magnitude (DeBano and others 1998; Robichaud 2005).

In the post-fire environment, road drainage features must accommodate flows under these changed and variable conditions to prevent failure. Road structures designed for the unburned forest condition are often unable to accommodate increased runoff, sediment, and debris following fire. BAER teams estimate post-fire increases in stream flows and make judgments on the ability of existing road structures to accommodate these new flow regimes. If necessary, treatments are prescribed to address user safety and road infrastructure investment, as well as to prevent disruption of use or unacceptable degradation of critical natural and cultural resources.

BAER team members use a variety of tools to estimate the post-fire increase in runoff and sediment. These vary from local expertise to computer models. This synthesis of commonly used post-fire assessment tools and road treatments will aid BAER team members in responding to the tight time frames allotted for rehabilitation decisions.

\section{Study Objectives}

The overall goal of this study was to develop a resource for BAER teams to assist them in making post-fire road rehabilitation decisions. We synthesized the most useful post-fire analysis tools for use in determining the required capacity of road structures and guidelines and procedures for prescribing road treatments after wildfire. Our specific objectives were to: (1) develop a questionnaire to 
acquire qualitative and quantitative information on post-fire road rehabilitation; (2) conduct interviews of BAER team engineers and hydrologists to define specific needs of BAER specialists with respect to post-fire road rehabilitation; (3) analyze gray literature and conduct additional literature review of relevant publications based on needs identified from interview results; (4) review and synthesize road rehabilitation procedures and analysis tools that would be most useful to BAER teams (specific tools of interest include those that estimate post-fire runoff and sediment flows and road structure capacities); (5) design an easily navigable post-fire road guide to access during rehabilitation responses (this included both on-line and hard copy resources); and (6) transfer information through workshops and presentations to agencies involved in post-fire road rehabilitation. This report summarizes our accomplishment of the study objectives. 


\section{Methods}

This study includes U.S. Forest Service BAER projects in the Western continental United States (Regions 1 through 6). We began by requesting Burned Area Report (FS-2500-8) forms and monitoring reports from the Regional headquarters and Forest Supervisors' offices. We developed interview questionnaires and interviewed BAER specialists regarding their experiences with post-fire rehabilitation. We also analyzed gray and peer-reviewed literature acquired from the interviews and literature search. We then reviewed and synthesized quantitative and qualitative information on procedures for prescribing road treatments after wildfire, estimating post-fire runoff and sediment, and determining road treatments.

\section{Burned Area Report Data}

The U.S. Forest Service Burned Area Report form contains the fire name and watershed location and the size, suppression cost, vegetation, soils, geology, length of stream channels, and roads and trails affected by the fire. The watershed description includes areas in low, moderate, and high burn severity categories and the area of water repellent soil. Erosion hazard ratings and estimates of erosion and sediment potential are included. Additionally, hydrologic design factors are included, such as estimated vegetation recovery, design chance of success, design storm recurrence interval, storm duration, storm magnitude, design flow, reduction in infiltration, and post-fire runoff flow. Values at risk are described and the probability of success for hillslope, channel, and road treatments are estimated. Cost estimates of no action (loss) versus cost of selected alternatives are identified, as well as BAER funds requested and other matching funds.

\section{Interview Survey}

We developed interview forms (Appendix A) after modification of the survey form from a previous study (Robichaud and others 2000). We used the forms to record information during interviews with BAER team members. Questions were designed to elicit opinions regarding the interviewees' experiences with the treatments used on their forests and other fires. The interview survey was comprised of three parts: (1) hydrologic design factor questions of Burned Area reports (e.g., how they estimated post-fire runoff and sediment); (2) road treatment questions (e.g., frequent-used road treatments); and (3) aftermath road treatment questions (e.g., success and failure of the prescribed treatments). Prior to conducting interviews, we requested information such as Burned Area Report forms and post-fire monitoring reports to familiarize the interviewer with the various fires and treatments used. We conducted onsite interviews because much of the supporting data were located in the interviewees' offices and could be retrieved during the interviews. We attempted to ask questions that would allow for ranking results because much of the information was qualitative. 


\section{Analysis Methods}

We analyzed interview survey results using Microsoft Excel ${ }^{\mathrm{TM}}$. We gave ranked information results a value from one to three with the first ranking receiving three points; the second two points; and the third one point. We evaluated runoff, peak flow, and sediment yield estimation methods used by BAER teams and described their benefits/drawbacks based on the comments of BAER interviewees, scientific literature, and the judgment of the proposal's PI and Co-PI as suggested by the JFSP (Joint Fire Sciences Program). Examples of the different estimation methods from BAER reports were provided and we grouped qualitative answers and comments so as to draw meaningful inferences. 


\section{Results and Discussion}

\section{Overview of Data Collected}

We categorized collected data into the following: (1) Burned Area Reports (FS 2500-8) acquired from Regional BAER coordinators, (2) published literature from a literature review/search, (3) interview results from BAER specialists, and (4) gray literature and unpublished data from interviewed BAER specialists. The published literature can be found in the references. A list of gray literature and unpublished data can be found in Appendix B.

\section{Interview Survey}

We interviewed a total of 30 BAER specialists. We visited a total of 28 BAER specialist offices to conduct interviews face-to-face and acquire any gray literature and monitoring reports while interviewing them. Two BAER specialists were interviewed by phone due to schedule conflicts. Interviewed BAER specialists were mostly hydrologists (45\%), engineers (22\%), and soil scientists $(20 \%)$ (table 1). Thus, we had a representative sample of specialists involved in post-fire runoff and sediment estimation methods and road treatment recommendations. The experience of the interviewed BAER specialists ranged from 6 to over 30 years.

Table 1-Background of interviewed BAER specialists by Regions.

\begin{tabular}{|c|c|c|c|c|c|c|c|}
\hline \multirow[b]{2}{*}{ Background } & \multirow[b]{2}{*}{ Overall } & \multicolumn{5}{|c|}{ Region } & \multirow[b]{2}{*}{6} \\
\hline & & 1 & 2 & 3 & 4 & 5 & \\
\hline Hydrology & 45 & 67 & 100 & 33 & 43 & 25 & 75 \\
\hline Engineering & 22 & & & 17 & 29 & 38 & 25 \\
\hline Soil & 20 & 33 & & 17 & 14 & 25 & \\
\hline Natural resource & 7 & & & 17 & 14 & & \\
\hline Forestry & 3 & & & 17 & & & \\
\hline Road management & 3 & & & & & 13 & \\
\hline No. of BAER interviewee responses & 30 & 6 & 1 & 6 & 7 & 8 & 2 \\
\hline
\end{tabular}

\section{Hydrologic design factor}

The Burned Area Report contains a section titled "Hydrologic Design Factors," which lists the factors used to estimate the need for post-fire treatments. The following section summarizes the interviewee's methodology used to complete this section. For each of the factors, we will discuss the most popular methods, comprising $80 \%$ of the responses. All responses are listed in each table.

For estimated vegetation recovery period, most of interviewed BAER specialists used "professional judgment" $(42 \%)$ or consulted with local botanists, 
ecologists, soil scientists, or hydrologists (39\%) (table 2). It was unclear what method the consulted specialists used. Research results $(8 \%)$ and " 2 to 3 years" $(8 \%)$ were the next popular responses.

For design chance of success, most BAER specialists (78\%) used professional judgment (table 3). The interviewed BAER specialists without hydrology or engineering backgrounds consulted with hydrologists (13\%). It was unclear what method the consulted hydrologists used.

For equivalent design recurrence interval, there was no clear preference and the most frequent answer was "consult w/hydrologist" (36\%). It was unclear what method the consulted hydrologist used. Fixed values of 10 years $(14 \%)$ and 25 years (14\%) were the next most common replies (table 4).

For design storm duration, there was no clear preference and the most frequent answer was "consult w/hydrologist" (44\%). It was unclear what method the consulted hydrologist used. One-hour duration (17\%), various duration depending on damaging storm (13\%), and 30-minute duration (12\%) were the next most common replies (table 5). Damaging storm is further discussed in the Damaging Storm section.

For design storm magnitude, a majority of the interviewees with a hydrology background used NOAA Atlas (46\%), and those without a hydrology background consulted with hydrologists (40\%) (table 6). It was unclear what method the consulted hydrologist used. A small number of BAER specialists used other methods, such as Parameter-Elevation Regressions on Independent Slopes Model (PRISM; Daly 2007) and CLIGEN (USDA ARS and Forest Service 2008). Also, one interviewee specifically identified that, for watershed less than $5 \mathrm{mi}^{2}$, the damaging storm is a 5-minute duration, 6-inch/hour intensity, convective storm in Regions 2 and 3. In Colorado, the damaging storm is a 2-year return period, 24-hour duration, 0.1 -inch/hour intensity convective storm in July or August.

Estimated reduction in infiltration was mostly estimated from soil burn severity (USDA Forest Service 2007) maps (46\%) or measured in the field (29\%) (table 7).

To estimate design flow (pre-fire peak flow), most of the interviewed BAER specialists used the USGS Regression (50\%), Curve Number (18\%), or consulted with a hydrologist (18\%) (table 8). It was unclear what method the consulted hydrologist used. To estimate adjusted design flow (post-fire peak flow), most of interviewed BAER specialists used the USGS Regression (43\%), Curve Number (28\%), Rule of Thumb by Kuyumjian (pers. comm., 2007 USDA Forest Service; 7\%) and TR55 (USDA NRCSb 2005; 7\%) (table 8). Detailed information about each method is discussed in the Post-fire Runoff and Erosion Estimation section.

\section{Road treatment}

The BAER FS-2500-8 form contains a section that describes the BAER team's road treatment recommendations. The following section summarizes the interviewees' preferred road treatments.

Rolling dips/water bars/cross drain, culvert upgrading, ditch cleaning, armoring, culvert removal, and trash racks constituted $80 \%$ of the most frequently used road treatments. All responses are shown in table 9 . The rolling dips/water bars/cross drain treatment was used most frequently throughout the Regions. Culvert upgrading was used mainly in Regions 1, 4, and 6 where fish habitat protection is a high priority. Culvert removal was used often in Region 3 where flash flooding is common. Trash racks were used in Regions 3 and 5, and culvert riser was used only in Region 5. 
Table 2-Estimated vegetation recovery period used by BAER specialists.

\begin{tabular}{lr}
\hline Estimated vegetation recovery period & $\%$ \\
\hline Professional judgment & 42 \\
Consult w/botanist, ecologist, soil & \\
$\quad$ scientist, and hydrologist & 39 \\
Research results & 8 \\
2-3 years & 8 \\
3-5 years & 3 \\
No. of BAER interviewee responses & 19 \\
\hline
\end{tabular}

Table 3-Design chance of success used by BAER specialists.

\begin{tabular}{lr}
\hline Design chance of success & $\%$ \\
\hline Professional judgment & 78 \\
Consult w/hydrologist & 13 \\
$80 \%$ & 4 \\
Risk table & 4 \\
No. of BAER interviewee responses & 23 \\
\hline
\end{tabular}

a Schmidt (1987) as shown in table 10.

Table 4-Equivalent design recurrence interval used by BAER specialists.

\begin{tabular}{lr}
\hline Equivalent design recurrence interval & $\%$ \\
\hline Consult w/hydrologist & 36 \\
10 years & 14 \\
25 years & 14 \\
5 years & 9 \\
100 years & 9 \\
Values at risk & 9 \\
Professional judgment & 9 \\
No. of BAER interviewee responses & 22 \\
\hline
\end{tabular}

Table 5-Design storm duration used by BAER specialists.

\begin{tabular}{lc}
\hline Design storm duration & $\%$ \\
\hline Consult w/hydrologist & 44 \\
1 hour & 17 \\
Depend on damaging storm & 13 \\
30 minutes & 12 \\
15 minutes & 6 \\
Less than 6 hours & 4 \\
Professional judgment & 4 \\
No. of BAER interviewee responses & 23 \\
\hline
\end{tabular}

Table 6-Design storm magnitude used by BAER specialists.

\begin{tabular}{lr}
\hline Design storm magnitude & $\%$ \\
\hline NOAA Atlas & 46 \\
Consult w/hydrologist & 40 \\
PRISM & 8 \\
Past experience & 4 \\
CLIGEN $^{\text {b }}$ & 2 \\
No. of BAER interviewee responses & 25 \\
\hline
\end{tabular}

a Daly (2007).

${ }^{\mathrm{b}}$ USDA Agricultural Research Service and Forest Service (2008).

Table 7-Estimated reduction in infiltration used by BAER specialists.

\begin{tabular}{lc}
\hline Estimated reduction in infiltration & $\%$ \\
\hline Soil burned severity maps & 46 \\
Field measurement $^{\mathrm{a}}$ & 29 \\
Consult w/soil scientist $^{-}$ & 10 \\
Previous studies & 6 \\
Back-calculation & 5 \\
Professional judgment & 3 \\
40\% for high/moderate burned area & 2 \\
No. of BAER interviewee responses & 22 \\
\hline a Infiltrometers were used. & \\
${ }^{b}$ Back-calculate from design flow and adjusted design flow.
\end{tabular}

Table 8-Pre- and post-fire peak flow estimation methods used by BAER specialists.

\begin{tabular}{lclr}
\hline Pre-fire peak flow estimation method & $\%$ & Post-fire peak flow estimation method & $\%$ \\
\hline USGS Regression & 50 & USGS Regression & 43 \\
Curve Number & 18 & Curve Number & 28 \\
Consult w/hydrologist & 18 & Rule of Thumb & 7 \\
TR55 & 7 & TR55 & 7 \\
No runoff/flow & 4 & Consult w/hydrologist & 7 \\
Professional judgment & 4 & WEPP & 5 \\
& & FERGI & 2 \\
No. of BAER interviewee responses & 28 & WATBAL & 2 \\
\hline
\end{tabular}


Table 9-Frequently recommended road treatments by BAER specialists by Region.

\begin{tabular}{|c|c|c|c|c|c|c|c|}
\hline \multirow[b]{2}{*}{ Method } & \multicolumn{7}{|c|}{ Region } \\
\hline & Overall & 1 & 2 & 3 & 4 & 5 & 6 \\
\hline & \multicolumn{7}{|c|}{ - - - - - - - - - - - - - - - - - - - - } \\
\hline Rolling dip/water bar/cross drain & 29 & 29 & & 27 & 30 & 19 & 42 \\
\hline Culvert upgrading & 20 & 33 & & & 48 & & 17 \\
\hline Ditch—cleaning, armoring & 16 & 25 & & 14 & 13 & 17 & \\
\hline Culvert removal & 10 & 6 & & 36 & & & 25 \\
\hline Debris/trash rack & 6 & & & 9 & & 19 & \\
\hline Armored ford crossing & 5 & & 33 & 5 & 4 & 6 & 8 \\
\hline Culvert riser & 5 & & & & & 19 & \\
\hline Storm patrol & 3 & & 50 & 9 & & & \\
\hline Culvert overflow bypass & 2 & & & & 4 & 6 & \\
\hline Hazard/warning sign & 1 & 2 & 17 & & & & \\
\hline Flared inlet & 1 & & & & & 6 & \\
\hline Channel debris cleaning & 1 & & & & & 6 & \\
\hline Culvert inlet/outlet armoring & 1 & 2 & & & & & \\
\hline Additional relief culvert & 1 & 2 & & & 3 & & \\
\hline Outsloping road & 1 & & & & & 3 & \\
\hline Fillslope armoring & 1 & & & & & & 8 \\
\hline No. of BAER interviewee responses & 30 & 8 & 1 & 6 & 5 & 8 & 2 \\
\hline
\end{tabular}

To calculate the treatment cost, BAER specialists consulted with engineers, followed regional cost guides, and modified and used the cost of previous years. Often, 3\% yearly interest was applied to the cost from the previous year. Some BAER specialists added a 20 to $25 \%$ emergency factor and a $35 \%$ overhead fee. Indefinite Delivery Indefinite Quantity (IDIQ) contracts were favored by some BAER specialists. IDIQs are contracts that provide for an indefinite quantity of supplies or services during a fixed period of time (Office of Federal Procurement Policy 2008).

\section{Road treatment effectiveness monitoring}

To evaluate the prescribed road treatments, monitoring reports and any follow up records are needed; however, most interviewed BAER specialists did not have these reports or records. A limited number of monitoring reports were acquired during the interviews. Most monitoring reports contained pictures and a description of the BAER treatments; however, they did not provide enough information to evaluate whether road treatments achieved their desired post-fire erosion mitigation.

\section{Post-Fire Road Rehabilitation Procedures}

When prescribing post-fire rehabilitation treatments, most BAER specialists followed similar procedures. Many BAER interviewees highlighted important aspects of these BAER procedures. The most notable comment was that prescribing road treatments differed among Regions because climates differed. The following is a list of post-fire road rehabilitation procedures identified by BAER specialists as useful in determining road recommendations.

\section{Values at risk}

BAER treatments are prescribed, prioritized, and implemented, depending on the values (e.g., life, safety, property) and/or resources (natural or cultural) 
that are at risk due to the burned condition of the forest. If there are no values or resources at risk, no BAER treatment is needed. A recent publication (Calkin and others 2007) provides a reliable and repeatable method to access values at risk.

\section{Damaging storm}

A damaging storm is a precipitation event that will likely threaten human lives or cause damage to property or road structures within the burned-over watershed or downstream values. A damaging storm can be a convective storm, summer thunderstorm, or rain-on-snow event, depending on the Region. A damaging storm is a (1) rain-on-snow event during spring snowmelt for mid- to high-elevation areas; (2) convective storm from May to September for the majority of other areas; and (3) winter frontal storm for portions of Regions 5 and 6.

Our interviews with the BAER team members indicated that while they had a clear understanding of what constituted a damaging storm, the term "design storm" was often used interchangeably with "damaging storm." A design storm is a storm event associated with a specified return period and is used as the basis for the design of stormwater-management systems. Both terms appear to be useful in BAER work, but we suggest a clear distinction be made between the two terms.

\section{Window of implementation}

The window of implementation should be carefully considered during the BAER assessment. The amount of time the BAER implementation team has before a damaging storm will most likely affect the burned watersheds. Therefore, the assessment team should determine the number of treatments that can be implemented, then prioritize the treatments based on values at risk. This is especially important for the southwestern United States, where fire season is usually from May to July and convective storms follow shortly thereafter. Ideally, the BAER treatments would be implemented within 3 to 4 weeks after the treatments are approved by the Washington Office. Any administrative help to speed up the BAER implementation is useful, such as:

- pre-ordering and stockpiling the necessary materials (such as warning signs);

- contracting implementation equipment and associated personnel using Indefinite Delivery/Indefinite Quantity (IDIQ) contracts; or

- developing close communication between assessment and implementation teams.

\section{Probability of success}

The probability of treatment success is closely related to the values at risk. If the values at risk are high, high probability of treatment success should be considered. The BAER treatment choice is determined by post-fire runoff, which is generated by precipitation events after wildland fires. Therefore, predicted precipitation events are crucial to the successful treatment selection. Future precipitation events can be estimated by using previous weather data, such as NOAA Atlas (NOAA 2008) or PRISM (Daly 2007). The probability of treatment success should consider the design storm (i.e., future precipitation events), design life of the treatments, and the recovery period following the fire. To calculate the chance of success of the treatment, Table 10 can be used. 
Table 10-Calculated risk table (recurrence interval in years) (Schmidt 1987).

\begin{tabular}{|c|c|c|c|c|c|c|c|c|c|c|c|c|c|c|c|c|c|c|c|c|}
\hline & & \multicolumn{19}{|c|}{ Risk - Percent chance } \\
\hline \multicolumn{2}{|c|}{ Success } & 95 & 90 & 85 & 80 & 75 & 70 & 65 & 60 & 55 & 50 & 45 & 40 & 35 & 30 & 25 & 20 & 15 & 10 & 5 \\
\hline \multicolumn{2}{|c|}{ Failure } & 5 & 10 & 15 & 20 & 25 & 30 & 35 & 40 & 45 & 50 & 55 & 60 & 65 & 70 & 75 & 80 & 85 & 90 & 95 \\
\hline \multirow{31}{*}{ 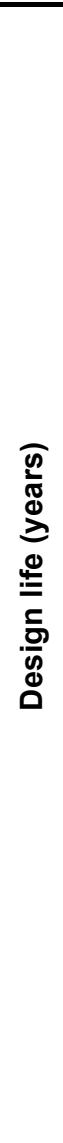 } & 1 & 20 & 10 & 7 & 5 & 4 & 4 & 3 & 3 & 3 & 2 & 2 & 2 & 2 & 2 & 2 & 2 & 2 & 2 & 2 \\
\hline & 2 & 40 & 20 & 13 & 10 & 8 & 6 & 5 & 5 & 4 & 4 & 4 & 3 & 3 & 2 & 2 & 2 & 2 & 2 & 2 \\
\hline & 3 & 59 & 29 & 19 & 14 & 11 & 9 & 8 & 7 & 6 & 5 & 4 & 4 & 3 & 3 & 3 & 2 & 2 & 2 & 2 \\
\hline & 4 & 78 & 39 & 25 & 19 & 15 & 12 & 10 & 8 & 7 & 7 & 6 & 5 & 4 & 4 & 4 & 3 & 3 & 2 & 2 \\
\hline & 5 & 98 & 48 & 32 & 23 & 18 & 15 & 13 & 10 & 9 & 8 & 7 & 6 & 6 & 5 & 4 & 4 & 3 & 3 & 2 \\
\hline & 6 & 117 & 58 & 38 & 28 & 22 & 17 & 15 & 12 & 11 & 10 & 8 & 7 & 7 & 6 & 5 & 4 & 4 & 3 & 2 \\
\hline & 7 & 136 & 67 & 44 & 32 & 25 & 20 & 17 & 14 & 12 & 11 & 9 & 8 & 7 & 6 & 6 & 5 & 5 & 4 & 3 \\
\hline & 8 & 156 & 77 & 50 & 37 & 28 & 23 & 20 & 16 & 14 & 12 & 11 & 9 & 8 & 7 & 7 & 5 & 5 & 4 & 3 \\
\hline & 9 & 175 & 86 & 56 & 41 & 32 & 26 & 22 & 18 & 16 & 13 & 12 & 10 & 9 & 8 & 7 & 6 & 5 & 4 & 4 \\
\hline & 10 & 195 & 96 & 63 & 46 & 35 & 29 & 24 & 20 & 17 & 15 & 13 & 11 & 10 & 9 & 8 & 7 & 6 & 5 & 4 \\
\hline & 11 & 214 & 104 & 69 & 50 & 39 & 31 & 27 & 22 & 19 & 16 & 14 & 13 & 11 & 10 & 9 & 7 & 6 & 5 & 4 \\
\hline & 12 & 234 & 114 & 75 & 55 & 42 & 34 & 29 & 24 & 21 & 18 & 16 & 14 & 12 & 10 & 9 & 8 & 7 & 6 & 5 \\
\hline & 13 & 254 & 124 & 81 & 59 & 46 & 37 & 31 & 26 & 22 & 19 & 17 & 15 & 13 & 11 & 10 & 9 & 7 & 6 & 5 \\
\hline & 14 & 273 & 133 & 86 & 64 & 49 & 40 & 34 & 28 & 24 & 21 & 18 & 16 & 14 & 12 & 11 & 9 & 8 & 7 & 5 \\
\hline & 15 & 293 & 143 & 93 & 68 & 53 & 43 & 36 & 30 & 26 & 22 & 19 & 17 & 15 & 13 & 12 & 10 & 8 & 7 & 6 \\
\hline & 16 & 312 & 152 & 99 & 73 & 56 & 45 & 38 & 32 & 27 & 24 & 20 & 18 & 16 & 14 & 12 & 10 & 9 & 8 & 6 \\
\hline & 17 & 332 & 162 & 105 & 77 & 60 & 48 & 40 & 34 & 29 & 25 & 22 & 19 & 17 & 15 & 13 & 11 & 9 & 8 & 6 \\
\hline & 18 & 351 & 171 & 111 & 82 & 63 & 51 & 43 & 36 & 31 & 26 & 23 & 20 & 18 & 15 & 14 & 12 & 10 & 8 & 7 \\
\hline & 19 & 371 & 181 & 117 & 86 & 67 & 54 & 45 & 38 & 32 & 28 & 24 & 21 & 19 & 16 & 14 & 12 & 11 & 9 & 7 \\
\hline & 20 & 390 & 190 & 123 & 91 & 70 & 57 & 47 & 40 & 34 & 29 & 26 & 22 & 20 & 17 & 15 & 13 & 11 & 9 & 8 \\
\hline & 25 & 488 & 238 & 154 & 113 & 88 & 71 & 59 & 50 & 42 & 36 & 32 & 28 & 25 & 22 & 19 & 16 & 14 & 11 & 9 \\
\hline & 30 & 585 & 285 & 185 & 135 & 105 & 85 & 71 & 60 & 51 & 44 & 38 & 33 & 29 & 25 & 22 & 19 & 16 & 14 & 11 \\
\hline & 35 & 683 & 333 & 216 & 157 & 122 & 99 & 82 & 70 & 59 & 51 & 45 & 39 & 34 & 30 & 26 & 23 & 19 & 16 & 12 \\
\hline & 40 & 780 & 380 & 247 & 180 & 140 & 113 & 94 & 79 & 68 & 58 & 51 & 44 & 39 & 34 & 29 & 25 & 22 & 18 & 14 \\
\hline & 45 & 878 & 428 & 277 & 202 & 157 & 127 & 105 & 89 & 76 & 66 & 57 & 50 & 43 & 38 & 33 & 28 & 24 & 20 & 15 \\
\hline & 50 & 975 & 475 & 308 & 225 & 174 & 141 & 117 & 99 & 85 & 73 & 63 & 55 & 48 & 43 & 37 & 32 & 27 & 22 & 17 \\
\hline & 60 & 1170 & 570 & 370 & 269 & 209 & 169 & 140 & 118 & 101 & 87 & 76 & 66 & 58 & 50 & 44 & 38 & 32 & 27 & 20 \\
\hline & 70 & 1365 & 665 & 431 & 314 & 244 & 197 & 163 & 138 & 118 & 101 & 89 & 77 & 67 & 59 & 51 & 44 & 37 & 31 & 24 \\
\hline & 80 & 1560 & 760 & 493 & 359 & 279 & 225 & 186 & 157 & 134 & 116 & 101 & 88 & 77 & 67 & 58 & 51 & 43 & 35 & 27 \\
\hline & 90 & 1755 & 855 & 554 & 404 & 313 & 253 & 209 & 177 & 151 & 130 & 113 & 99 & 86 & 75 & 66 & 57 & 48 & 40 & 31 \\
\hline & 100 & 1950 & 950 & 616 & 449 & 348 & 281 & 233 & 196 & 168 & 145 & 126 & 110 & 96 & 84 & 73 & 63 & 53 & 44 & 34 \\
\hline
\end{tabular}

Example 1: If a culvert through a road is to last for 20 years with a $25 \%$ chance of failure (or $75 \%$ chance of success), the culvert should be designed for the 70-year flood recurrence event. Failure in this context means that the recurrence interval flood is equaled or exceeded at least once during the specific design life. The culvert may or may not physically fail or be washed out.

Example 2: The same culvert above is used for post-fire condition in which 7-year post-fire flood is equal to 70-year pre-fire flood. Postfire condition will last for only 3 years; therefore, the design life will be 3 years. Then percent chance of success decreased from $75 \%$ to $60 \%$ if the existing culvert is used for post-fire condition.

\section{Post-fire runoff increase}

Post-fire runoff increase is estimated based on the design storm. Each BAER team used their preferred method. The interview survey showed that a majority of BAER specialists use the following methods, ranked from high to low (table 8): (1) USGS Regression, (2) Curve Number, (3) Rule of Thumb by Kuyumjian, (4) Water Erosion Prediction Project (WEPP) Model, and (5) FireEnhanced Runoff and Gully Initiation (FERGI) Model. Detailed information on each method is found in the Post-fire Runoff and Sediment Estimation section.

\section{Capacity of existing road structures}

If existing road structures can handle the increased post-fire peak flow, no further treatment is needed. However, in some cases, the existing road structures can not handle the increased flow, and they should be removed or upgraded if the values at risk warrant the expected expense. Also, many BAER specialists recommended considering a bulking factor to account for the debris and 
sediment delivered with increased runoff from the burned upland area. Typical bulking factors range from 0.1 to 0.25 . Limited information exists on road structure capacities, and estimates must be made using on-site measurements and calculations. Road structures, such as culverts and rolling dips/water bars, are further discussed in the BAER Road Treatments, Culvert Sizing, and Rolling Dip/Water Bar sections.

\section{Choosing a road treatment}

Post-fire road treatments should be implemented after considering the factors discussed previously. The interview survey showed that BAER specialists use the following treatments, ranked from high to low (table 9): (1) rolling dips/ water bars/cross drain, (2) culvert upgrading, (3) ditch cleaning and armoring, and (4) culvert removal.

\section{Post-Fire Runoff and Erosion Estimation}

To prescribe road treatments, it is essential to determine whether the existing drainage structure can handle the post-fire runoff increase. Extensive literature indicates that streamflow increases after fires through a combination of the hydrologic processes summarized in table 11.

There is a general consensus that post-fire streamflow can increase, often with orders of magnitude larger than pre-fire events, especially for watersheds of high and moderate burn severity. Burned watersheds can yield runoff that quickly produces flash floods. The largest post-fire peak flow often occurs in smaller watersheds. Bigio and Cannon (2001) reported that specific discharges were the greatest from relatively smaller watersheds $\left(<0.4 \mathrm{mi}^{2}\right)$ with an average

Table 11—Changes in hydrologic processes caused by wildfires (Neary and others 2005).

\begin{tabular}{|c|c|c|}
\hline Hydrologic process & Type of change & Specific effect \\
\hline Interception & Reduced & $\begin{array}{l}\text { Moisture storage smaller } \\
\text { Greater runoff in small storms } \\
\text { Increased water yield }\end{array}$ \\
\hline Litter and duff storage of water & Reduced & $\begin{array}{l}\text { Less water stored } \\
\text { Overland flow increased }\end{array}$ \\
\hline Transpiration & Temporary elimination & $\begin{array}{l}\text { Streamflow increased } \\
\text { Soil moisture increased }\end{array}$ \\
\hline Infiltration & Reduced & $\begin{array}{l}\text { Overland flow increased } \\
\text { Stormflow increased }\end{array}$ \\
\hline Stream flow & Changed & $\begin{array}{l}\text { Increased in most ecosystems } \\
\text { Decreased in snow systems } \\
\text { Decreased on fog-drip systems }\end{array}$ \\
\hline Baseflow & Changed & $\begin{array}{l}\text { Decreased (less infiltration) } \\
\text { Increased (less evaporation) } \\
\text { Summer low flows (+ and -) }\end{array}$ \\
\hline Stormflow & Increased & $\begin{array}{l}\text { Volume greater } \\
\text { Peakflows larger } \\
\text { Time to peakflow shorter } \\
\text { Flashflood frequency greater } \\
\text { Flood levels higher } \\
\text { Stream erosive power increased }\end{array}$ \\
\hline Snow accumulation & Changed & $\begin{array}{l}\text { Fires }<10 \text { ac, increased snowpack } \\
\text { Fires }>10 \text { ac, decreased snowpack } \\
\text { Snowmelt rates increased } \\
\text { Evaporation and sublimation greater }\end{array}$ \\
\hline
\end{tabular}


discharge of $17,700 \mathrm{cfsm}\left(\mathrm{cfs} \mathrm{mi}^{-2}\right)$ or $28 \mathrm{cfs} \mathrm{acre}^{-1}$, while discharges from the next larger sized watersheds $\left(0.4 \mathrm{mi}^{2}\right.$ to $\left.4 \mathrm{mi}^{2}\right)$ averaged $2,100 \mathrm{cfsm}$. Increased post-fire flow may transport debris that was produced by the fire. Often, the post-fire peak flow is a combination of water flow and debris, called bulking. Road treatments should be prescribed and implemented if existing drainage structures can not handle the post-fire runoff increase.

BAER specialists have been using several methods to estimate post-fire runoff: USGS Regression, Curve Number, Rule of Thumb by Kuyumjian, ERMiT, FERGI, and WATBAL. The following is a discussion of each of these methods.

\section{USGS Regression method}

The USGS Regression method is the most commonly used post-fire runoff estimation method by BAER team members ( $43 \%$; table 8$)$.

The Department of Interior U.S. Geological Survey (USGS) has developed a method to estimate magnitude and frequency of floods of both gaged and ungaged streams. The flood-frequency relations at gaged and ungaged sites were developed for various hydrologic regions based on their stream gage records, basin characteristics, and numerous studies throughout the United States. These flood-frequency relations are often called and expressed as a form of "USGS regression equations," since a regression analysis was used to develop the flood frequency relations.

\section{Input Requirements}

To use the USGS Regression method, the following information is required:

- USGS Regression equations for the areas of interests (burned sites);

- gauged data from the watersheds of interests (if any);

- basin characteristics, such as the drainage area, elevation, precipitation, free water-surface evaporation, latitude, longitude, forest and herbaceous cover, high elevation area, channel slope, soil storage capacity and permeability, and minimum and maximum January temperatures (the actual required basin characteristics vary depending on the hydrologic regions. Fortunately, not all of these characteristics are required for a single region.);

- design storm intensity, duration, and recurrence interval;

- size of high soil burn severity areas; and

- water repellency and surface runoff increase of high/moderate soil burn severity area, which should be determined by users.

\section{Program Availability}

USGS Regression equation methods have been incorporated into StreamStats (USGS 2007), which is a web-based tool used to obtain streamflow information. StreamStats are available for many states and are being implemented for the others (fig. 1). Users can access StreamStat online (http://water.usgs.gov/osw/ streamstats/index.html) and estimate peak flow at a given location.

\section{How to Use}

The following steps are used to apply the USGS Regression method for estimation of post-fire peak flow:

1. Find the USGS Regression equations for the area of interest

2. Collect the basin characteristics of burned areas 
Figure 1-Availability of StreamStats for the U.S. (USGS 2007).
Fully implemented

Delineation and basin characteristics implemented Implemented and testing internally

Undergoing implemented

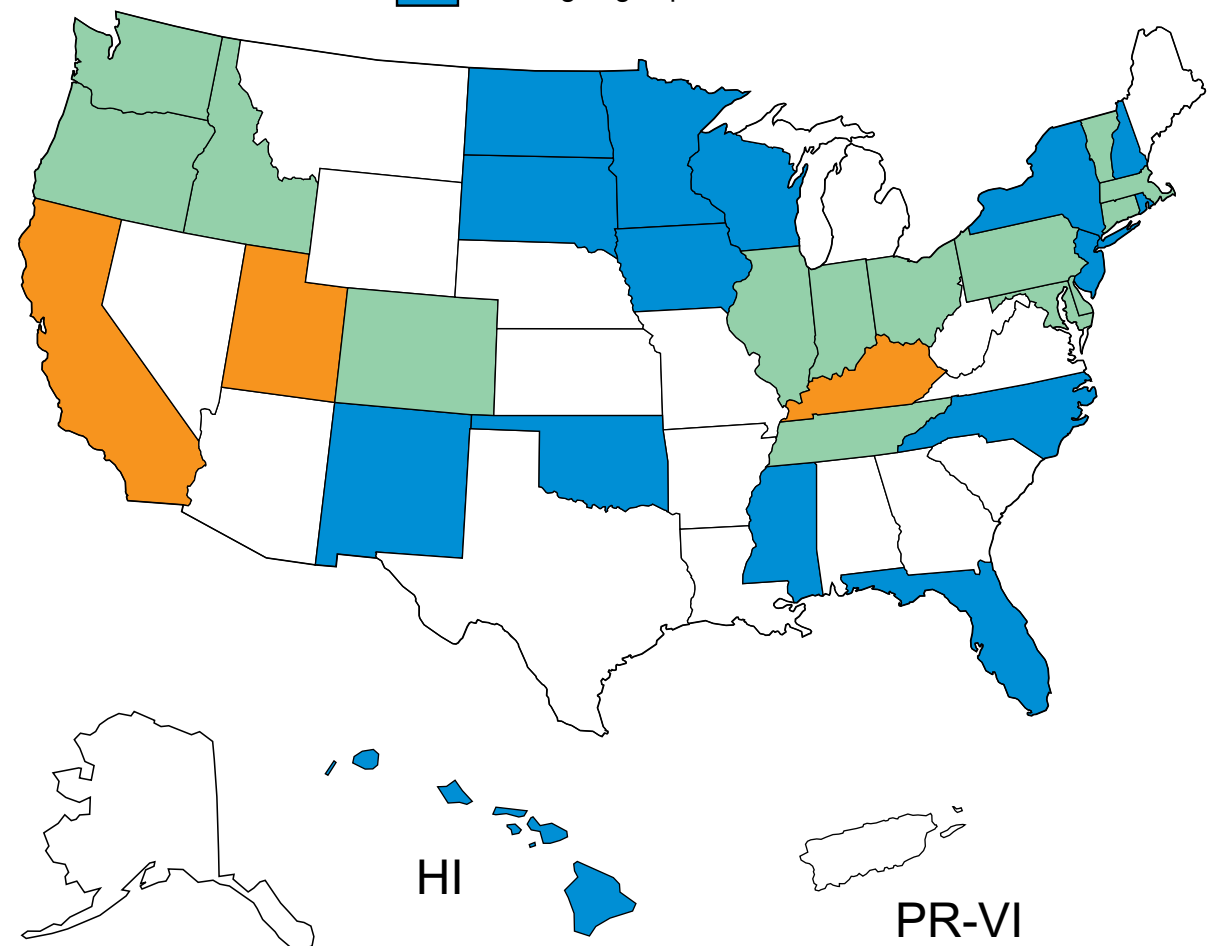

AK

3. Collect information about the burned area, such as percentage of high and moderate soil burn severity areas

4. Determine design/damaging storm, including storm intensity, duration, and recurrence interval

5. Estimate pre-fire runoff assuming no fires and unburned area for the area of interest

6. Determine the percent runoff increase for high and moderate soil burn severity area compared to pre-fire runoff (a difficult step, as described below)

7. Determine modifier that is defined as a ratio of post-fire to pre-fire runoff and calculated as follows:

$$
\text { modifier }=1+\frac{\text { Percent runoff increase }}{100 \%} \times \frac{\left(A_{H}+A_{M}\right)}{A_{T}}
$$

where

$A_{H}=$ high burn severity area within the watershed (acre or $\mathrm{mi}^{2}$ );

$A_{M}=$ moderate burn severity area within the watershed (acre or $\mathrm{mi}^{2}$ ), and;

$A_{T}=$ total watershed area (acre or $\mathrm{mi}^{2}$ ).

8. Estimate post-fire runoff by multiplying the modifier and pre-fire runoff 


\section{Discussion}

Since there are very limited studies and guidelines to determine the modifier or the percent runoff increase for high and moderate burn severity, BAER team members often rely on simple rules of their own. For example, some Region 1 BAER specialists used 100\% runoff increase (double the runoff amount) for high/moderate soil burn severity areas in the first year of the fire, such as the 2006 Derby Fire (Story and others 2006). Also, they assumed 1/3 and 1/6 soil water repellency with a 10 -fold surface runoff increase for high soil burn severity areas for the same year and for 1 year after the 2000 Skalkaho/Valley Complex Fires in Montana (2007 USDA Forest Service).

Some BAER team members in Region 1 skipped steps 6 through 8 and used a USGS Water-Resources Investigations Report (Parrett and others 2004) to estimate post-fire peak flow for their burned areas. This report provided post-fire runoff responses 1 year after a fire in three burned areas in Montana (Canyon Ferry, Ashland, and Bitterroot fires). Once the BAER team members chose a design storm and a station with a drainage area similar in size to their burned area, they could determine the matching post-fire peak flow for their burned areas. However, the report by Parrett and others (2004) did not provide information about the size of burned areas and burn intensities within watersheds. Care should be taken when using a USGS report to estimate post-fire peak flow for burned areas when more detailed burned area conditions are unavailable.

\section{Advantages}

The following were advantages to applying the USGS regression method for post-fire runoff and erosion estimation. The USGS Regression method:

- is applicable for estimating both pre- and post-fire peak flow;

- estimates peak flow, regardless of the storm duration and intensity;

- is appropriate for larger watersheds, which are greater than $5 \mathrm{mi}^{2}$;

- does not usually require detailed watershed information, such as soil and topography;

- is more accurate if gaged data is used from the watershed of interest;

- is applicable to longer duration events, and snowmelt runoff events.

\section{Disadvantages}

The following were disadvantages to applying the USGS regression method for post-fire runoff and erosion estimation.

- It does not estimate erosion.

- It does not consider post-fire debris flow/torrent.

- The user must find the appropriate USGS Regression equations for the watershed in the pre-fire condition.

- The user must find the appropriate USGS Regression equations for the watershed in the post-fire condition (if any).

- The user must determine the modifier, or the soil water repellency and postfire runoff increase, for high and moderate burn severity areas.

- It uses only English units.

\section{Example}

The Bitterroot National Forest had Skalkaho/Valley Complex Fires in 2000, and had a 10-yr, 24-hour storm event on 1 September 2001. It was 
Table 12-Comparison of observed and estimated peak flows using USGS regression method from 10year, 24-hour storm event 1 year after the 2000 Skalkaho/Valley Complex Fires in the Bitterroot National Forest, Montana (2002 USDA Forest Service).

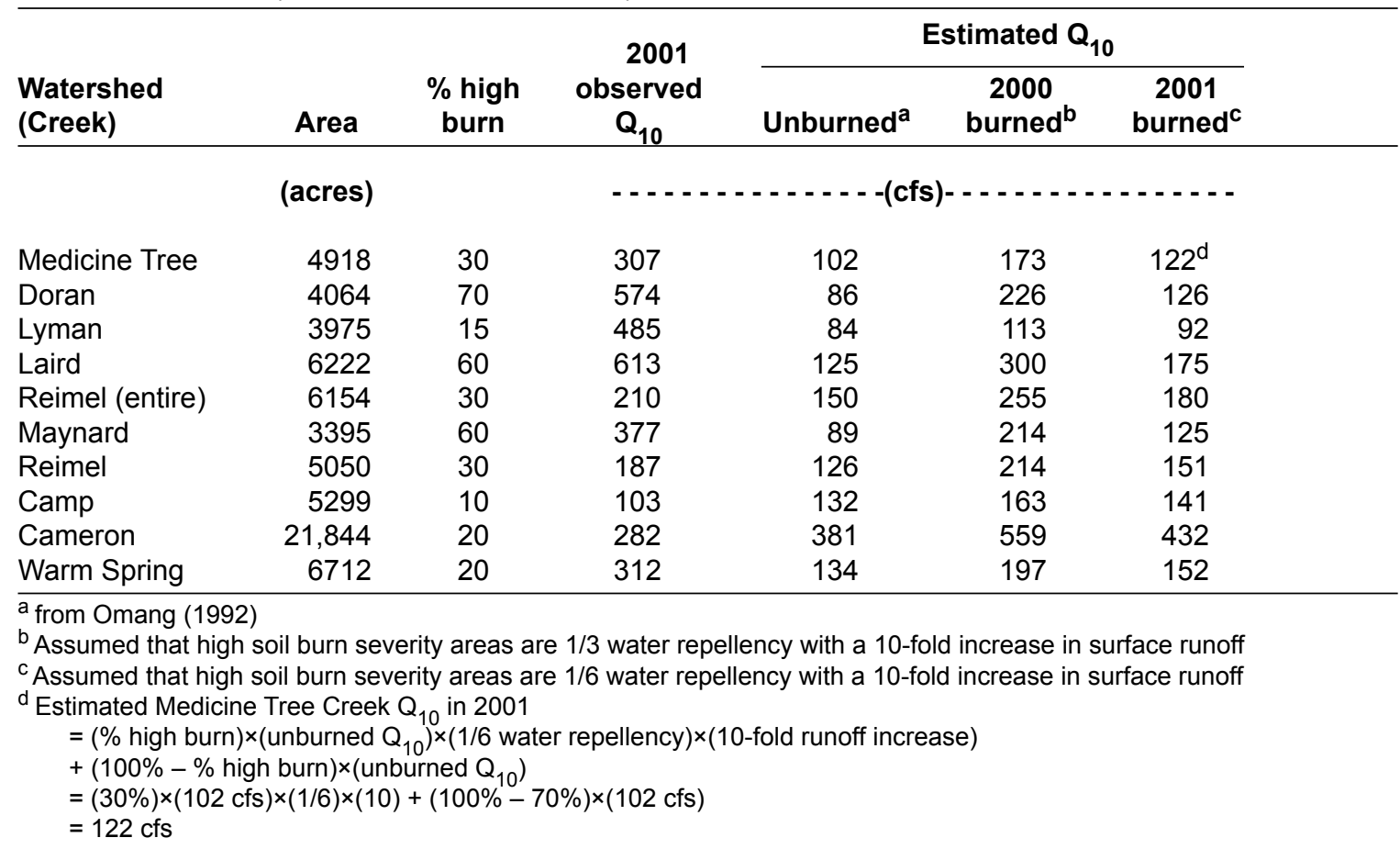

assumed that $1 / 3$ of the high soil burn severity areas had soil water repellency and a 10-fold increase in surface runoff. USGS Regression method (Omang 1992) was used to calculate peak flows in the unburned condition. Observed and estimated peak flows are provided in table 12.

Plotting percent of high soil burn severity area and observed post-fire peak flow showed that they are somewhat related $\left(r^{2}=0.47\right)$ (fig. 2). Figure 3 shows that observed post-fire peak flow does not match estimated post-fire peak flow, assuming 1/6 soil water repellency with a 10-fold increase in surface runoff for high soil burn severity areas. Better soil water repellency effects should be developed and moderate soil burn severity areas should be considered for inclusion in the estimation.

Detailed information about how to use the USGS Regression methods can be found in Appendix C.

\section{Curve Number methods}

The NRCS Curve Number methods are the second most commonly used post-fire runoff estimation method by BAER team members (30\%; table 8$)$.

The Curve Number method was developed by the U.S. Department of Agriculture Natural Resources Conservation Service (NRCS), formerly the Soil Conservation Service (SCS), to estimate runoff depth. It considers rainfall, soils, cover type, treatment/conservation practices, hydrologic conditions, and topography (slope steepness). Users have to choose a Curve Number (CN) based on cover type, treatment, hydrologic conditions, and Hydrologic Soil Group to estimate runoff and peak flow; therefore, the Curve Number is the single most important parameter in this method. 
Figure 2-High burn severity area and observed post-fire peak flow (10-year, 24-hour) from the 2000 Skalkaho/Valley Complex Fires in the Bitterroot National Forest, Montana (2002 USDA Forest Service).
Figure 3-Observed and estimated post-fire peak flow (10-year, 24-hour) from the 2000 Skalkaho/Valley Complex Fires in the Bitterroot National Forest, Montana (2002 USDA Forest Service). Estimated post-fire peak flow does not match observed flow.
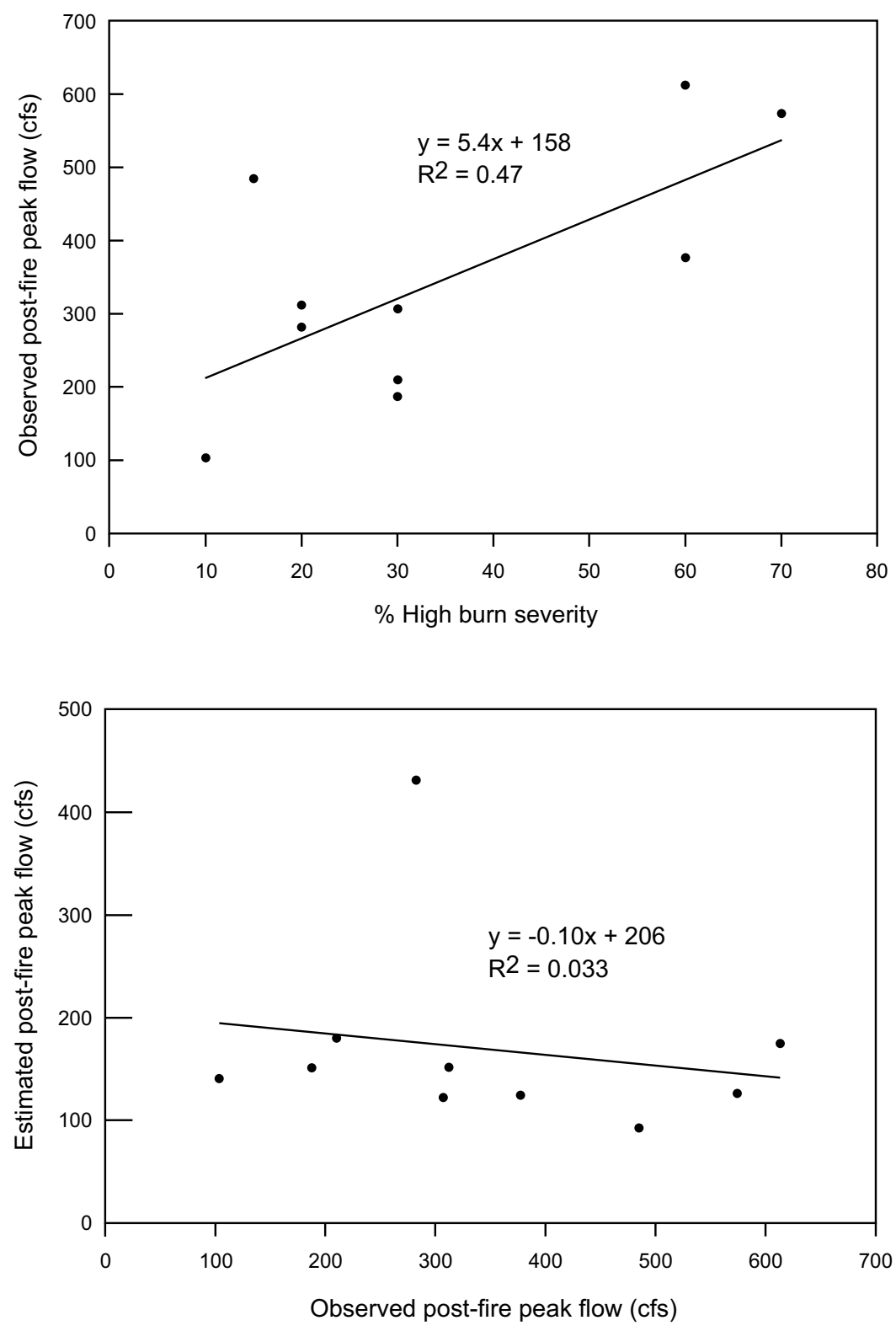

\section{Input Requirements}

To use NRCS Curve Number methods, the following information is required (USDA SCS 1991):

- drainage area in $\mathrm{ft}^{2}, \mathrm{mi}^{2}$, or acres;

- rainfall amount for a storm duration of 24 hours, with a given recurrence interval;

- Hydrologic Soil Groups (table 13) in which the watershed soil is classified;

- average watershed slope in percent;

- flow length the longest flow path, from the watershed divide to the outlet, in feet; and

- pre-fire and post-fire runoff Curve Numbers. 


\begin{tabular}{|c|c|c|}
\hline Group & Description & Minimum infiltration rate \\
\hline & & $\left(\right.$ inch $\mathrm{h}^{-1}$ ) \\
\hline A & $\begin{array}{l}\text { Low runoff potential and high infiltration rates, } \\
\text { and consists chiefly of sands and gravels. }\end{array}$ & Greater than 0.30 \\
\hline B & $\begin{array}{l}\text { Moderate infiltration rates, and have } \\
\text { moderately fine to moderately coarse texture. }\end{array}$ & 0.15 to 0.30 \\
\hline C & $\begin{array}{l}\text { Low infiltration rates, and consists chiefly of } \\
\text { soils having a layer that impedes downward } \\
\text { movement of water and soils of moderately } \\
\text { fine to fine texture. }\end{array}$ & 0.05 to 0.15 \\
\hline $\mathrm{D}$ & $\begin{array}{l}\text { High runoff potential and very low infiltration } \\
\text { rates, and consists mainly of clay soils, soils } \\
\text { with a permanent high water table, or shallow } \\
\text { soils over nearly impervious material. }\end{array}$ & Less than 0.05 \\
\hline
\end{tabular}

\section{Program Availability}

There are two Curve Number methods that BAER teams frequently useWILDCAT4, (Hawkins and Greenberg 1990) an MS DOS program, and FIRE HYDRO (Cerrelli 2005), an EXCEL spreadsheet. The WILDCAT4 is a storm runoff/hydrograph model that uses triangular unit hydrographs. The WILDCAT4 model requires the following information:

- name of the watershed;

- average land slope (\%) and the length of the longest channel (ft) or time of concentration (hr);

- area (acre) of Hydrologic Response Unit (HRU), which is an area having a consistent hydrologic response;

- CN of HRU;

- storm duration (hrs);

- storm rainfall depth (inches); and

- storm distribution type, either SCS Type II (fig. 4), Farmer-Fletcher (for central and north-central Utah; Farmer and Fletcher 1972), uniform, custom, or generic.

If a 'Generic' distribution is chosen, the following information is needed:

- the minimum and maximum storm intensities (as a percent of the mean storm intensity) and

- the timing of the peak flow intensity (as a percent of the storm duration).

The WILDCAT4 should be applied to watersheds of $5 \mathrm{mi}^{2}$ or less. The WILDCAT4 main menu, watershed data, storm data, and summary output screens are shown in figures 5 through 8.

WILDCAT4 is easy to use. However, the user has to specify the CN of preand post-fire conditions and the program runs in DOS. WILDCAT5, a Windows version of the WILDCAT program, is in development and will be released in the near future (Hawkins, pers. comm. 2008 Univ. of AZ). 


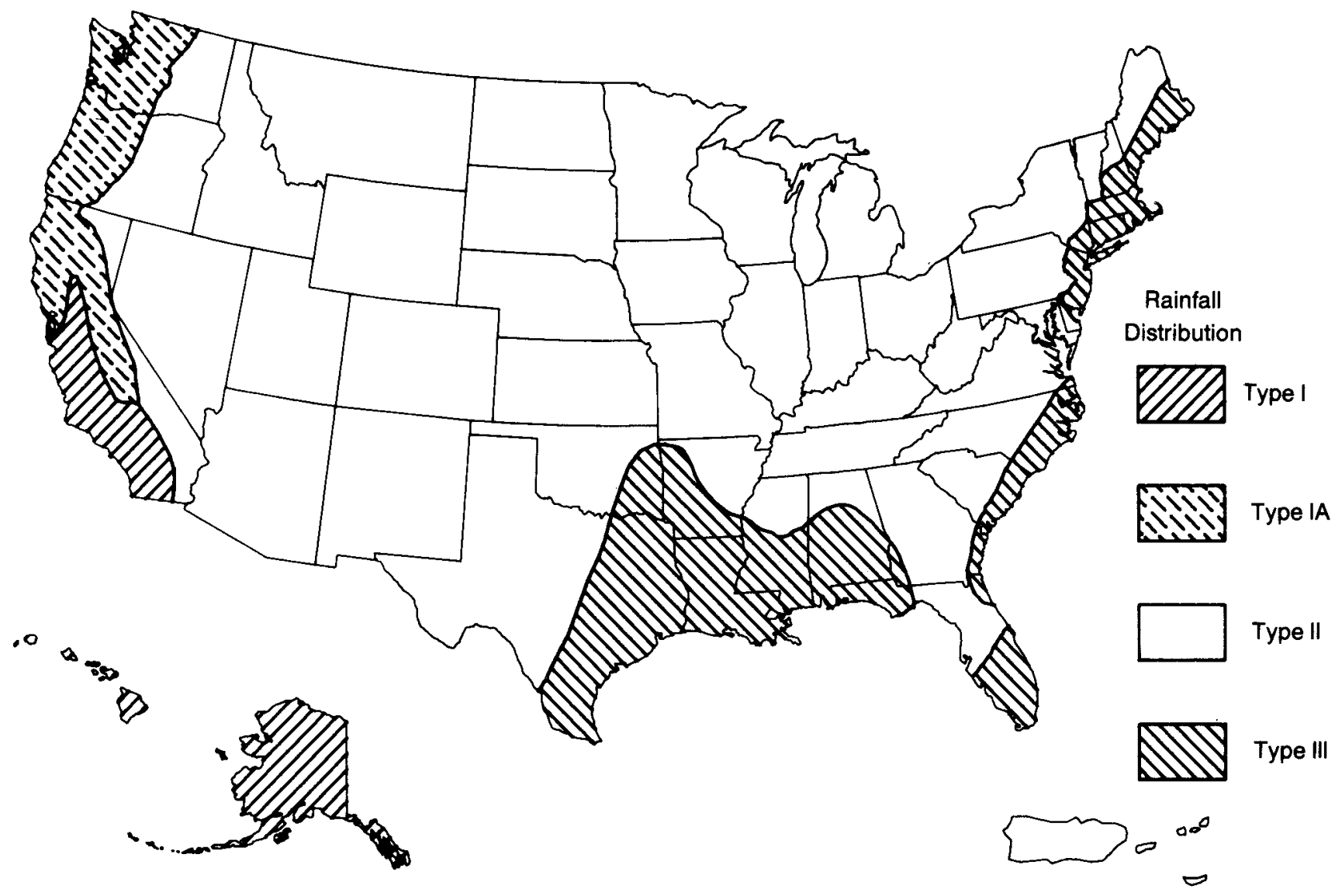

Figure 4-Approximate geographic boundaries for SCS rainfall distributions (USDA SCS 1991).

Figure 5-WILDCAT4 main menu screen.

Figure 6-WILDCAT4 watershed data screen.
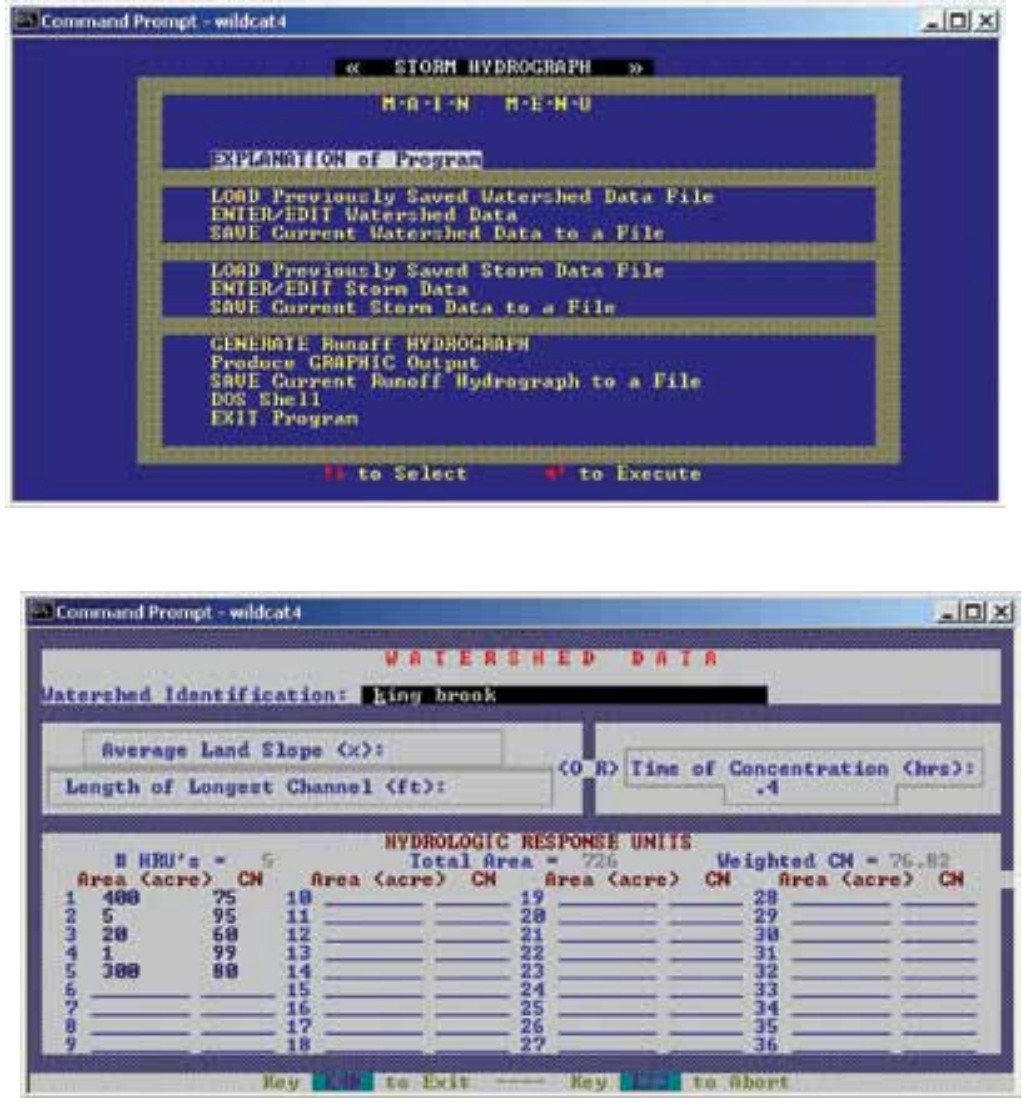
Figure 7-WILDCAT4 storm data screen.

Figure 8-WILDCAT 4 summary output screen.
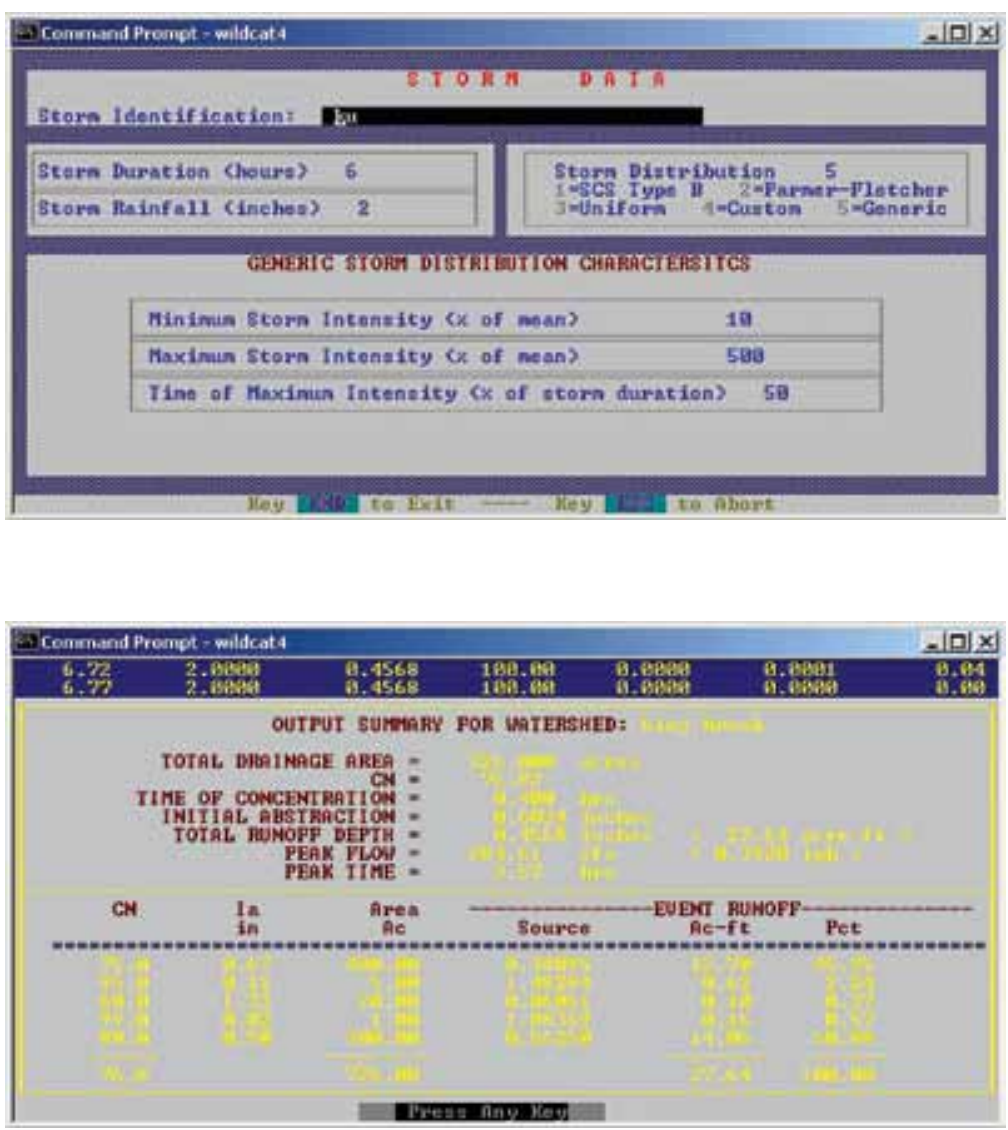

Cerrelli (2005) developed a spreadsheet, called FIRE HYDRO, to assist NRCS and Forest Service personnel in estimating design peak flows for the burned areas of Montana. The FIRE HYDRO is a peak flow analysis tool for the 2-, 5-, 10-, 25-, 50-, and 100-year, 24-hour rainfall runoff events for the pre- and post-fire conditions. The required input data includes the following: drainage area (acre); average watershed slope (\%); CN; and 2- to 100-year, 6and 24-hour rainfall depths that are available from the NOAA web site (2008). The 6- and 24-hour rainfall depths are required to determine the SCS rainfall distribution type (Type I, IA, II, or III) (fig. 4). Most of Region 1, including Montana, has Type II, which produce the highest peak flow among the SCS rainfall distribution types. The FIRE HYDRO spreadsheets are shown in figures 9 through 11. Cerrelli (2005) assumed that the runoff Curve Numbers of bare soil cover type or poor hydrologic condition were used for post-fire conditions. However, there is no clear guideline to choose post-fire runoff Curve Numbers. The FIRE HYDRO is applicable for 24-hour rainfall events only, and is not applicable for short duration rainfall events such as a 1-hour storm or less. 
Figure 9-Explanatory section of FIRE HYDRO (Cerrelli 2005), an EXCEL spreadsheet to assist to estimate peak flows for the burned areas of Montana.
Figure 10-Runoff Curve Number $(\mathrm{CN})$ section of FIRE HYDRO (Cerrelli 2005), an EXCEL spreadsheet to assist to estimate peak flows for the burned areas of Montana.

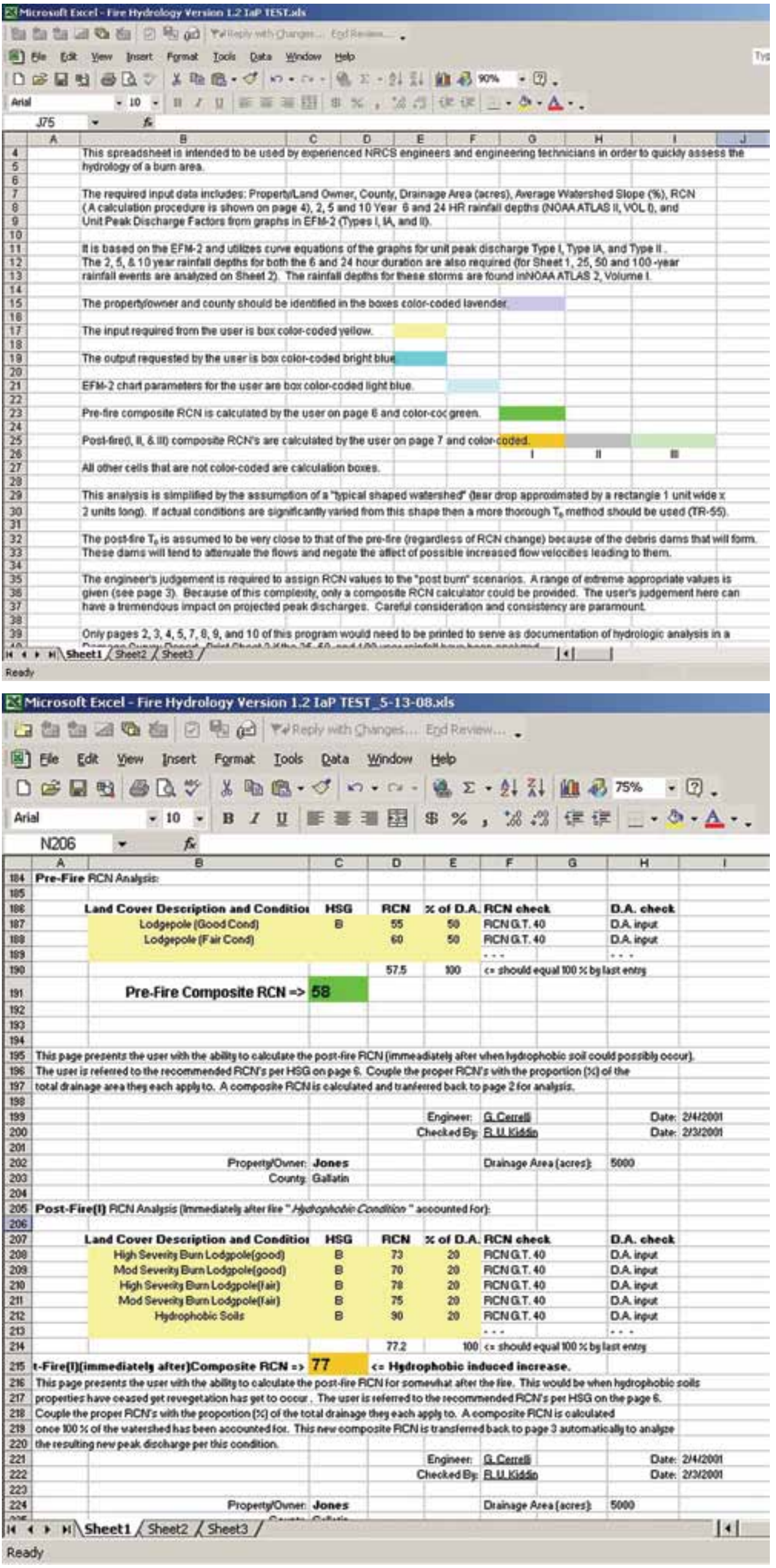


Figure 11-Input and output section showing prefire and post-fire peak flow of FIRE HYDRO (Cerrelli 2005), an EXCEL spreadsheet to assist to estimate peak flows for the burned areas of Montana. The 5,000 acre drainage area had a prefire 25-year peak flow of 186 cfs with a CN of 58 and post-fire peak flow of $1,088 \mathrm{cfs}$ with a $\mathrm{CN}$ of 77 , calculated from figure 9 .

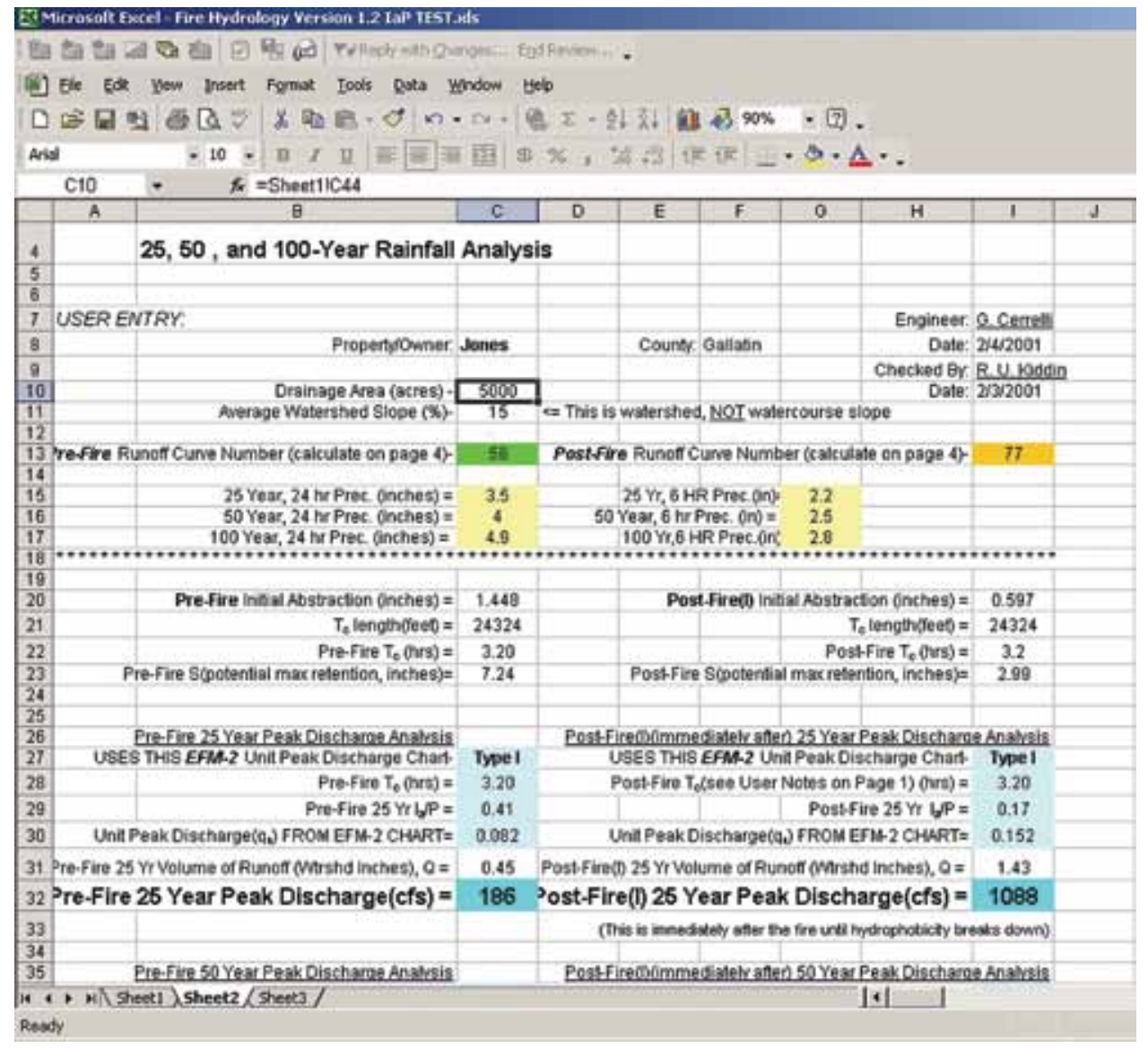

\section{Discussion}

There are limited numbers of studies that provide post-fire runoff Curve Numbers. Springer and Hawkins (2005) attempted to provide a guideline to choosing post-fire runoff Curve Numbers based on the 2000 Cerro Grande Fire in New Mexico, and concluded that "the post-fire trends in CN and peak flows are not readily explained and will be a topic of future research."

Livingston and others (2005) provided a guideline to choose the post-fire runoff numbers with a range of values as seen in table 14. They used computed $\mathrm{CNs}$ and compared pre-and post-fire CNs for 31 small $\left(0.12\right.$ to $\left.2.5 \mathrm{mi}^{2}\right)$ subbasins in the Los Alamos area, New Mexico, and 24 small $\left(0.11\right.$ to $\left.2.3 \mathrm{mi}^{2}\right)$ subbasins affected by the 2002 Long Mesa Fire at Mesa Verde National Park, Colorado. To classify the soil burn severity of the whole watershed/basin, they used Wildfire Hydrologic Impact (WHI), based on the percentage of high and moderate soil burn severity (table 15 and fig. 12) and a general relation between pre- and post-fire $\mathrm{CN}$ ratio (fig. 13). Post-fire runoff $\mathrm{CN}$ can be estimated using

Table 14-Post-fire curve numbers (CNs) for various burn severities (Livingston and others 2005).

\begin{tabular}{lc} 
Soil burn severity & Estimated CN \\
\hline Unburned & 55 to 75 \\
Low & 80 to 83 \\
Moderate, without water repellent soils & 87 \\
Moderate, with water repellent soils & 89 \\
High, without water repellent soils & 92 \\
High, with water repellent soils & 95 \\
\hline
\end{tabular}


Table 15-Variations in Wildfire Hydrologic Impact (WHI) classification due to high soil burn severity (Livingston and others 2005).

\begin{tabular}{cc}
$\begin{array}{c}\text { Percentage of subbasins with } \\
\text { a high soil burn severity }\end{array}$ & $\begin{array}{c}\text { Wildfire Hydrologic Impact } \\
\text { classification }\end{array}$ \\
\hline $0-6$ & Low \\
$7-48$ & Moderate \\
$49-80$ & Severe \\
\hline
\end{tabular}

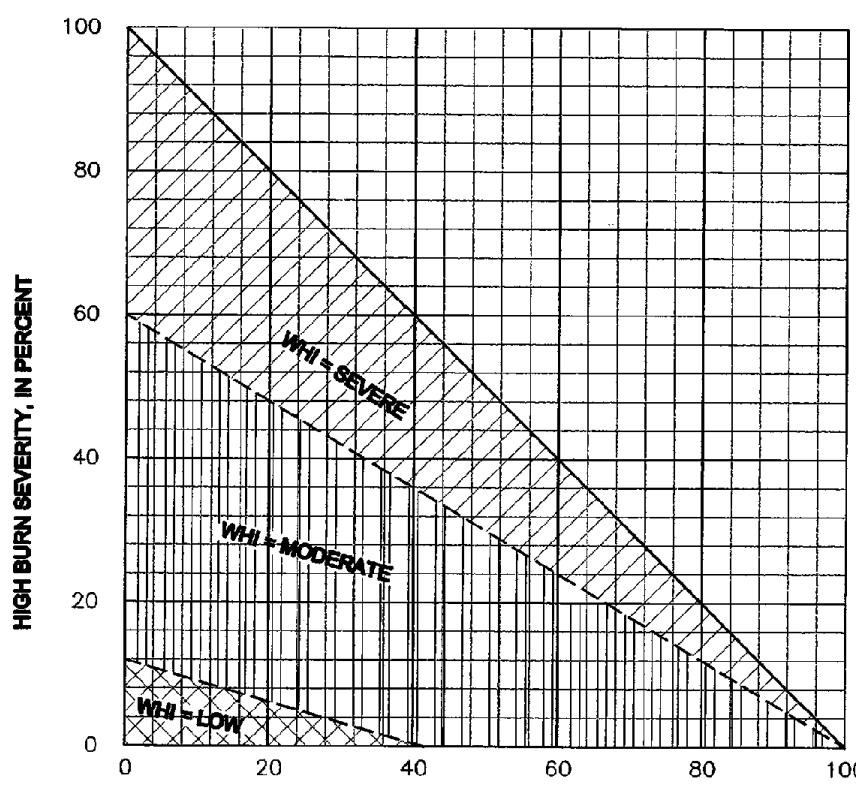

Figure 12-Wildfire Hydrologic Impact (WHI) for small burned subbasins as a function of soil burn severity (Livingston and others 2005).

Figure 13-General relation between pre- and initial post-fire curve number $(\mathrm{CN})$ ratio for indicated Wildfire Hydrologic Impact (Livingston and others 2005).

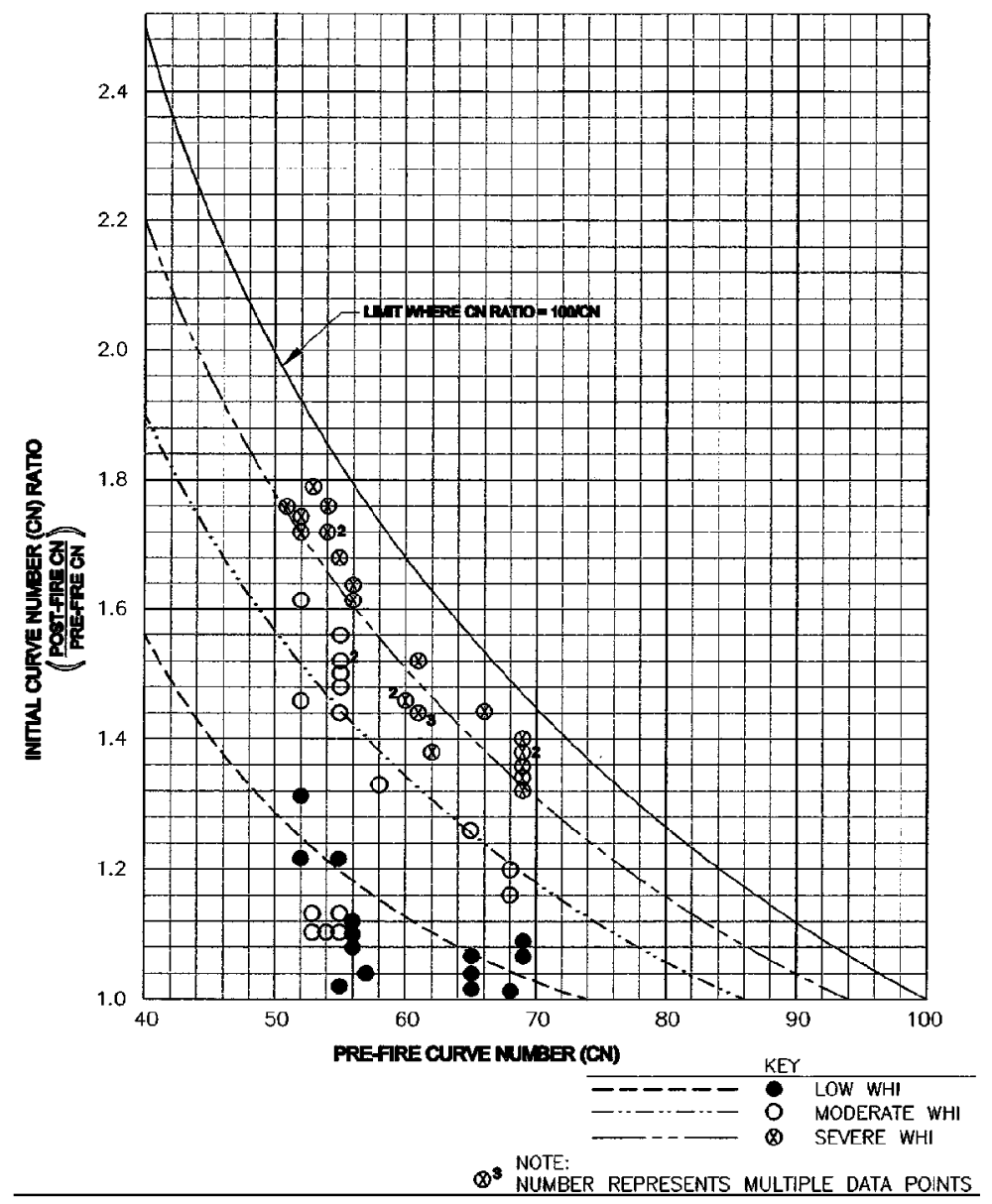


Table 16-Post-fire Curve Numbers (CNs) for various burn severities based on the Bitterroot National Forest, Montana (Cerrelli 2005).

\begin{tabular}{|c|c|c|}
\hline Soil burn severity & Sub-category & Estimated CN \\
\hline \multirow[t]{4}{*}{$\mathrm{High}^{\mathrm{a}}$} & $\mathrm{HSG}^{\mathrm{b}} \mathrm{A}$ & 64 \\
\hline & HSG B & 78 \\
\hline & HSG C & 85 \\
\hline & HSG D & 88 \\
\hline Moderate & & Use cover type ${ }^{C}$ in Fair condition \\
\hline \multirow[t]{2}{*}{ Low and Unburned } & North and East facing slopes & Use cover type in Good condition \\
\hline & South and West facing slopes & Use cover type between Fair and Good conditions \\
\hline Any & Water repellent soils & $94^{\mathrm{d}}$ \\
\hline $\begin{array}{l}{ }^{a} \text { High burn severity aree } \\
\text { debris by June of the } \\
\text { evaluation experienc } \\
{ }^{b} \text { Hydrologic Soil Group } \\
{ }^{c} \text { From table D. } 2 \text { and D. } 3 \\
{ }^{d} \text { Rule of thumb by Mont }\end{array}$ & $\begin{array}{l}\text { assumed to have attained at least } \\
\text { g year after the fire, and the } \mathrm{CN} \text { va } \\
\text { 13. } \\
\text { ndix D. } \\
\text { SS. }\end{array}$ & $\begin{array}{l}\text { und cover consisting of vegetation, duff, thick ash, or wood } \\
\text { re from three Montana NRCS engineers with hydrologic }\end{array}$ \\
\hline
\end{tabular}

figure 13 if pre-fire $\mathrm{CN}$ is known. Pre-fire $\mathrm{CN}$ should be determined by users using various sources such as table D.2 and D.3 in Appendix D. Their study results are applicable to the Los Alamos area and other areas in the southwest with similar pre-fire $\mathrm{CN}$ values and hydrology; however, they are less applicable to areas with different pre-fire rainfall and runoff characteristics.

An experienced BAER team member in Region 1 suggested using a $\mathrm{CN}$ of 90 to 95 for high soil burn severity without water repellent soils and 93 to 98 for high soil burn severity with water repellent soils (2003 USDA Forest Service). The Livingston $\mathrm{CN}$ values are within the range suggested by Story.

Cerrelli (2005) provided a guideline to select post-fire $\mathrm{CN}$ based on burn severity and hydrologic soil grouping specific to the Bitterroot National Forest wildfires (table 16). He did not find appropriate CNs in his initial search of the literature for $\mathrm{CN}$ values for burned areas in southwestern Montana. Consequently, Montana NRCS engineers created a guideline based on the existing NRCS CN/ land use table (e.g., table D.2 and D.3). However, no gaging or calibrating took place to verify or improve this guideline. The 2-year to 5-year, 24-hour storm events occurred in the following spring and summer. Runoff from these storm events did not cause failure of the BAER treatments assessed and implemented using this CN guideline (Cerrelli 2005).

Since there are very limited studies and guidelines for choosing CNs for post-fire conditions, BAER team members often use simple rules of their own. Details on these rules are found in the NRCS CN Methods section. For example, in the Salt Creek BAER Hydrology Special Report (Higginson and Jarnecke 2007), they used the following rules to determine post-fire CNs.

- High burn severity $\mathrm{CN}=$ pre-fire $\mathrm{CN}+15$

- Moderate burn severity $\mathrm{CN}=$ pre-fire $\mathrm{CN}+10$

- Low burn severity $\mathrm{CN}=$ pre-fire $\mathrm{CN}+5$

- Maximum $\mathrm{CN}$ value is 100

Once the user has determined CNs for each HRU within a watershed, the problem arises of how to combine them. CNs and runoff depth are not linearly related (Grove and others 1998). A weighted average of all CNs in a watershed is commonly used to reduce the number of calculations, which is an assumption that $\mathrm{CNs}$ and runoff are linearly related. The underestimation of runoff 
using weighted average $\mathrm{CNs}$ is most severe for wide $\mathrm{CN}$ ranges, as would occur in watersheds containing low and high severity burns. Low $\mathrm{CN}$ values and low precipitation depths, as would occur in unburned southwestern watersheds, would result in underestimation of runoff. Therefore, care should be exercised when applying weighted average CNs.

Another approach is to use distributed CNs in a GIS application. However, White (1988) and Stuebe and Johnson (1990) reported that using distributed CNs resulted in as much as 100 percent higher runoff than using weighted average CNs.

The preferred method to estimate runoff from watersheds with different CNs is to combine runoff amounts from each HRU.

\section{Advantages}

The following were advantages to applying the NRCS CN methods for postfire runoff and erosion estimation.

- NRCS CN methods are applicable for input to methods that calculate peak flow.

- Two CN methods and models (WILDCAT4 and FIRE HYDRO) are available for post-fire application.

- WILDCAT4 considers shorter-duration storms (e.g., 15-minute) to 24-hour storm duration, which is adequate for the regions where the damaging storm is short duration, such as 15 or 30 minutes.

\section{Disadvantages}

The following were disadvantages to applying the NRCS CN methods for post-fire runoff and erosion estimation.

- NRCS CN methods do not estimate erosion.

- NRCS CN methods do not consider post-fire debris flow/torrent.

- NRCS CN methods are applicable to smaller watersheds, which are less than $5 \mathrm{mi}^{2}$.

- The FIRE HYDRO method only considers 24-hour storm duration.

- The user must determine pre-fire and post-fire $\mathrm{CN}$ that is a sensitive parameter; therefore, the estimated peak flow is subjective to users.

- There are no guidelines to determine post-fire CN except in Regions 1 and 3.

- There is difficulty in combining runoff from areas of different CNs within a watershed. Instead, users interchangeably use a weighted average of all CNs in a watershed.

- The NRCS CN methods will likely underestimate runoff when applying weighted average of CNs for high burn severity area in arid weather conditions.

- The NRCS CN methods use English units only.

\section{Example}

The Blackerby Fire on the Nez Perce National Forest near Grangeville, Idaho, occurred in August 2005. On 19 May 2006 a 0.79-inch precipitation event with a 30-minute duration occurred over a portion of the burned area. The precipitation event was equivalent to a 25-year, 30-minute storm event as determined from the NOAA Atlas 2 (Miller and others 1973b). 
The NRCS CN flood flow model results used in the BAER analysis (using FIRE HYDRO) were for a 25-year return event and based on the assumption of limited soil and vegetation regeneration during the first year after the fire. The observed flood discharge value was $71 \mathrm{cfs}$, or $56 \mathrm{cfsm}\left(\mathrm{cfs} \mathrm{mi}^{-2}\right)$. This observed flood discharge was half that of predicted flow. Additionally, the observed debris flow discharge was $620 \mathrm{cfs}$, or $492 \mathrm{cfsm}$, indicating that debris flow discharge was nearly an order of magnitude greater than the flood discharge. Details of the results can be found in the NRCS CN Methods section.

Detailed information on how to use the NRCS Curve Number methods can be found in Appendix D.

\section{Rule of Thumb by Kuyumjian}

The Rule of Thumb by Kuyumjian has been used by Region 3 BAER team members, or about $7 \%$ of BAER interviewees (table 8 ).

Experienced BAER team members often use their own rule of thumb, which they developed based on their experience and post-fire monitoring/observation and works well within certain regions. An experienced BAER hydrologist (Kuyumjian, pers. comm. 2007 USDA Forest Service) suggested using the following rule of thumb, which requires a minimal amount of input information.

\section{Input Requirements}

To use the Rule of Thumb by Kuyumjian, the following information is required:

- area of high and moderate soil burn severity and

- anticipated precipitation amount from a damaging storm.

\section{How to Use}

There are two steps to apply the Rule of Thumb by Kuyumjian for estimating post-fire peak flow:

1. Determine the design/damaging storm, including storm intensity, duration, and recurrence interval.

2. Estimate the post-fire peak flow $\left(\mathrm{Q}_{\mathrm{p}}\right)$ using the following relationship:

$$
Q_{p}=300 \times A_{s} \times I \times 1.25
$$

where

$$
\begin{aligned}
Q_{p} & =\text { peak flow in cfs; } \\
I & =\text { precipitation intensity in inch/hour; } \\
A_{s} & =\text { size of high and moderate burn severity area in } \mathrm{mi}^{2} ; \text { and } \\
1.25 & =\text { bulking factor. }
\end{aligned}
$$

\section{Discussion}

The Rule of Thumb by Kuyumjian is similar to the rainfall-discharge relation that was determined for 31 data pairs in 2001 and 17 data pairs in 2002 from seven sub-watersheds in the Rendija Canyon watershed after the 2000 Cerro Grande Fire (Moody and others 2007). About $82 \%$ of the Rendija Canyon watershed was severely burned. Their analysis was based on the change in the normalized burn ratio ( $\triangle$ NBR; Key and Benson 2006), which incorporates reflectance measurements from Landsat imagery and was designed to measure the fire effects on vegetation and soil characteristics. Watersheds with $581 \pm 5 \%$ can 
be categorized as high or moderate-high burn severity (Cocke and others 2005; Key and Benson 2006). The rainfall-discharge relation was:

$$
Q_{u}^{\text {peak }}=b \cdot\left(I_{30}-I_{30}^{\text {thresh }}\right)
$$

where

$$
\begin{aligned}
Q_{u}^{\text {peak }} & =\text { peak flow per unit area }\left(\text { inch }^{-1}\right) ; \\
b & =\text { unit-less constant; } \\
I_{30}= & 30 \text { minutes rainfall intensity }\left(\text { inch }^{-1}\right) ; \text { and } \\
I_{30}^{\text {thresh }}= & \text { the largest value of } I_{30} \text { below which no surface } \\
& \text { flow occurs }\left(\text { inch } \mathrm{h}^{-1}\right) .
\end{aligned}
$$

Moody and others (2007) reported $b$ and $I_{30}^{\text {thresh }}$ values as shown in table 17 . The rainfall-discharge relation can be used to compare the Rule of Thumb by Kuyumjian. Using combined b and $I_{30}^{\text {thresh }}$ values from table 17, assuming $I_{30}$ » $8.5 \mathrm{~mm} \mathrm{~h}^{-1}\left(0.33 \mathrm{inch} \mathrm{h}^{-1}\right)$ and the entire drainage area was high severity burn area, equation 3 can be reduced to:

$$
Q^{\text {peak }}=303 \times A_{\mathrm{s}} \times I_{30}
$$

\begin{tabular}{|c|c|c|c|c|}
\hline Year & b & $I_{30}^{\text {thresh }}$ & $r^{2}$ & $\mathbf{p}$ \\
\hline \multicolumn{5}{|c|}{$\left(\mathrm{mm} \mathrm{h}^{-1}\right)$} \\
\hline 2001 & 0.50 & 7.6 & 0.73 & $<0.001$ \\
\hline 2002 & 0.43 & 11.1 & 0.52 & 0.001 \\
\hline 2001 and $2002^{a}$ & 0.47 & 8.5 & 0.63 & $<0.001$ \\
\hline
\end{tabular}

This is very close to the rule of thumb by Kuyumjian without the bulking factor of 1.25 .

Table 17- $b$ and $I_{30}^{\text {thresh }}$ values in the rainfall-discharge relation from the Rendija Canyon watershed after the 2000 Cerro Grande Fire, New Mexico (Moody and others 2007).

\section{Advantages}

The following were advantages to applying the Rule of Thumb by Kuyumjian for post-fire runoff and erosion estimation. The Rule of Thumb by Kuyumjian:

- is applicable for estimating post-fire peak flow;

- is a simple and quick approximation;

- does not need to determine parameter values; and

- considers bulking factor for post-fire debris flow/torrent. 


\section{Disadvantages}

The following were disadvantages to applying the rule of thumb by Kuyumjian for post-fire runoff and erosion estimation. The Rule of Thumb by Kuyumjian:

- does not estimate erosion;

- is only applicable for short-duration (1 hour or less) high intensity (greater than 0.5 inches) storms;

- is not applicable for estimating peak flow from snowmelt or rain-on-snow or frozen ground;

- currently evaluated only for Region 3; and

- uses English units only.

\section{Example}

Approximately $4.8 \mathrm{mi}^{2}$ of the Rendija Canyon watershed was burned by the 2000 Cerro Grande Fire: $82 \%$ at high severity, $10 \%$ at moderate severity, $6 \%$ at low severity, and $2 \%$ was unburned (Gallaher and Koch 2004). Seven subwatersheds were monitored for rainfall intensity and discharge in 2001 and 2002 (Moody and others 2007). Four subwatersheds had $581 \pm 5 \%$ of $\triangle \mathrm{NBR}$ value that was considered high or moderate-high burn severity (Cocke and others 2005; Key and Benson 2006).

Assuming the entire drainage area was high severity burn area, peak flow per unit drainage area $\left(\mathrm{cfs} \mathrm{mi}^{-2}\right)$ can be calculated based on rainfall intensity that is greater than 0.5 inches. The Rule of Thumb by Kuyumjian estimated less than half $(47 \%)$ of the peak flows were within $\pm 50 \%$ of observed values (table 18$)$, which can be from uncertainty associated with discharge and rainfall intensity measurements or natural variation that the rule of thumb cannot consider.

Table 18-Comparison of observed and estimated peak flow using the Rule of Thumb by Kuyumjian from various rainfall intensities $\left(>0.5\right.$ inch $\left.^{-1}\right)$ for 2001 in four high severity burn subwatersheds of Rendija Canyon after the 2000 Cerro Grande Fire, New Mexico (Moody and others 2007).

\begin{tabular}{|c|c|c|c|c|}
\hline \multirow[b]{2}{*}{ Watershed } & \multirow[b]{2}{*}{ Date } & \multirow[b]{2}{*}{$\begin{array}{c}\text { Rainfall } \\
\text { intensity } I_{30}\end{array}$} & \multicolumn{2}{|c|}{ Peak flow per unit drainage area } \\
\hline & & & Observed & $\begin{array}{c}\text { Estimated by } \\
\text { Rule of Thumb }\end{array}$ \\
\hline & & $\left(\right.$ inch $\mathrm{h}^{-1}$ ) & \multicolumn{2}{|c|}{ - - - - (cfs mi-2)- - . } \\
\hline 3 & 2 Jul & 2.07 & 686 & 622 \\
\hline 3 & $13 \mathrm{Jul}$ & 0.88 & 151 & 263 \\
\hline 3 & 9 Aug & 1.50 & 405 & 449 \\
\hline 9 & 2 Jul & 0.90 & 41 & 269 \\
\hline 9 & $26 \mathrm{Jul}$ & 1.45 & 777 & 435 \\
\hline 9 & 9 Aug & 0.59 & 28 & 177 \\
\hline 9 & 11 Aug & 0.90 & 154 & 270 \\
\hline 11 & 2 Jul & 1.69 & 461 & 508 \\
\hline 11 & $26 \mathrm{Jul}$ & 1.30 & 333 & 389 \\
\hline 11 & 11 Aug & 1.28 & 333 & 384 \\
\hline 13 & 2 Jul & 0.65 & 65 & 195 \\
\hline 13 & 2 Jul & 1.13 & 182 & 339 \\
\hline 13 & $2 \mathrm{Jul}$ & 1.10 & 43 & 331 \\
\hline 13 & $11 \mathrm{Jul}$ & 0.73 & 39 & 219 \\
\hline 13 & 11 Aug & 1.28 & 264 & 384 \\
\hline
\end{tabular}

\footnotetext{
${ }^{a}$ Bulking factor is not considered only to compare observed peak flow.
} 
Seven of the BAER team members used TR-55 to calculate post-fire runoff increase (table 8).

The TR-55 requires the runoff Curve Number $(\mathrm{CN})$ as an input parameter; therefore, it can be considered as a Curve Number method. The TR-55 was released as a simplified procedure to calculate the storm runoff volume, peakflow rate, hydrograph, and storage volume for storm water management structures in small watersheds in urban areas, assuming the NRCS Type II rainfall distribution for all calculations (USDA SCS 1975). Later, a major revision was made to improve the model by adding three more rainfall distributions (Type I, IA, and III; fig. 4), programming the computations, and estimating time of concentration using split separate flow phases (USDA SCS 1986).

\section{Input Requirements}

Required input data is as follows (USDA NRCS 2005b):

- identification data;

- dimensionless unit hydrograph;

- storm data;

- rainfall distribution;

- area;

- Runoff Curve Number (CN); and

- time of concentration details.

\section{Program Availability}

The current version of TR-55 computer model is WinTR-55, which was revised and completely rewritten. It uses the TR-20 model (USDA NRCS 2005a), a NRCS storm event surface water hydrologic model applied at a watershed scale, as the driving engine for all the hydrograph procedures (USDA NRCS 2005b).

WinTR-55 is a single-event, rainfall-runoff hydrologic model for small watersheds with multiple sub-areas that are homogeneous. It generates hydrographs from urban and agricultural areas and the generated hydrographs are routed downstream through channels or reservoirs.

\section{Discussion}

WinTR-55 model can be run in either English or Metric units. The WINTR-55 model and related documents are available at the NRCS web site http://www. wsi.nrcs.usda.gov/products/W2Q/H\&H/Tools_Models/WinTR55.html.

WinTR-55 model requires input data shown in table 19. For its applications on the BAER road treatments, the TR-55 should be run once for pre-fire watershed conditions and again for post-fire conditions.

\section{Advantages}

The following were advantages to applying the WinTR-55 for post-fire runoff and erosion estimation. WinTR55:

- is applicable for estimating peak flow;

- estimates time to peak;

- is applicable to larger watersheds, which are less than $25 \mathrm{mi}^{2}$; and

- uses both English and metric units. 
Table 19-WinTR-55 variables and their ranges (USDA NRCSb 2005).

\begin{tabular}{ll} 
Variable & \multicolumn{1}{c}{ Range } \\
\hline Minimum area & $\begin{array}{l}\text { No absolute minimum area. The user should carefully examine results } \\
\text { from sub-area less than } 1 \text { acre. }\end{array}$ \\
$\begin{array}{l}25 \mathrm{mi}^{2}(6,500 \text { ha }) \\
\text { Maximum area }\end{array}$ & $\begin{array}{l}1 \text { to } 10 \\
\text { Number of sub-watersheds }\end{array}$ \\
Time of concentration for any sub-area & 0.1 hour $\leq \mathrm{T}_{\mathrm{C}} \leq 10$ hour \\
Number of reaches & 0 to 10 \\
Type of reaches & Channel or structure \\
Reach routing & Muskingum-Cunge \\
Structure routing & Storage-indication \\
Structure types & Pipe or weir \\
Structural trial sizes & 1 to 3 \\
Rainfall depth & Default or user-defined \\
& 0 to 50 inches (0 to 1,270 mm) \\
Rainfall distributions & NRCS Type I, IA, II, III (fig. 4), NM60, NM65, NM70, NM75, \\
& or user-defined \\
Rainfall duration & 24 -hour \\
Dimensionless unit hydrograph & Standard peak rate factor 484, or user-defined
\end{tabular}

\section{Disadvantages}

The following were disadvantages to applying the WinTR-55 for post-fire runoff and erosion estimation. WinTR55:

- does not estimate erosion;

- does not consider post-fire debris flow/torrent;

- only considers 24-hour storm duration, so it is not applicable to the regions where the damaging storm duration is much shorter, such as 15 or 30 minutes;

- requires the user to determine pre-fire and post-fire $\mathrm{CN}$ that is a sensitive parameter, so the estimated peak flow is subjective to users; and

- does not provide guidelines to determine post-fire $\mathrm{CN}$, except for Regions 1 and 3.

\section{Example}

The TR-55 model was used to estimate post-fire peak flows on the 2002 Bullock fire. Table 20 shows the analysis that was conducted. The "2-year postfire equivalent" displays the corresponding flood level expected from a typical 2-year storm event.

\section{Water Erosion Prediction Project (WEPP) Model: Erosion Risk Management Tool (ERMiT)}

The ERMiT (Robichaud and others 2006, 2007), a FS WEPP Interface, has been used by the BAER team members (5\%; table 8$)$, primarily from Region 4.

The WEPP model was developed by an interagency group of scientists from the U.S. Department of Agriculture's Agricultural Research Service, Forest Service, and Soil Conservation Service (currently Natural Resources Conservation Service); U.S. Department of Interior Bureau of Land Management; U.S. Geological Survey; and several university cooperators. The WEPP model predicts soil erosion and sediment delivery by water using stochastic weather 
Table 20-Hydrological analysis 2-year, post-fire equivalent flood level using TR-55 for the 2002 Bullock Fire in the Coronado National Forest, Arizona (Lefevre and others 2002).

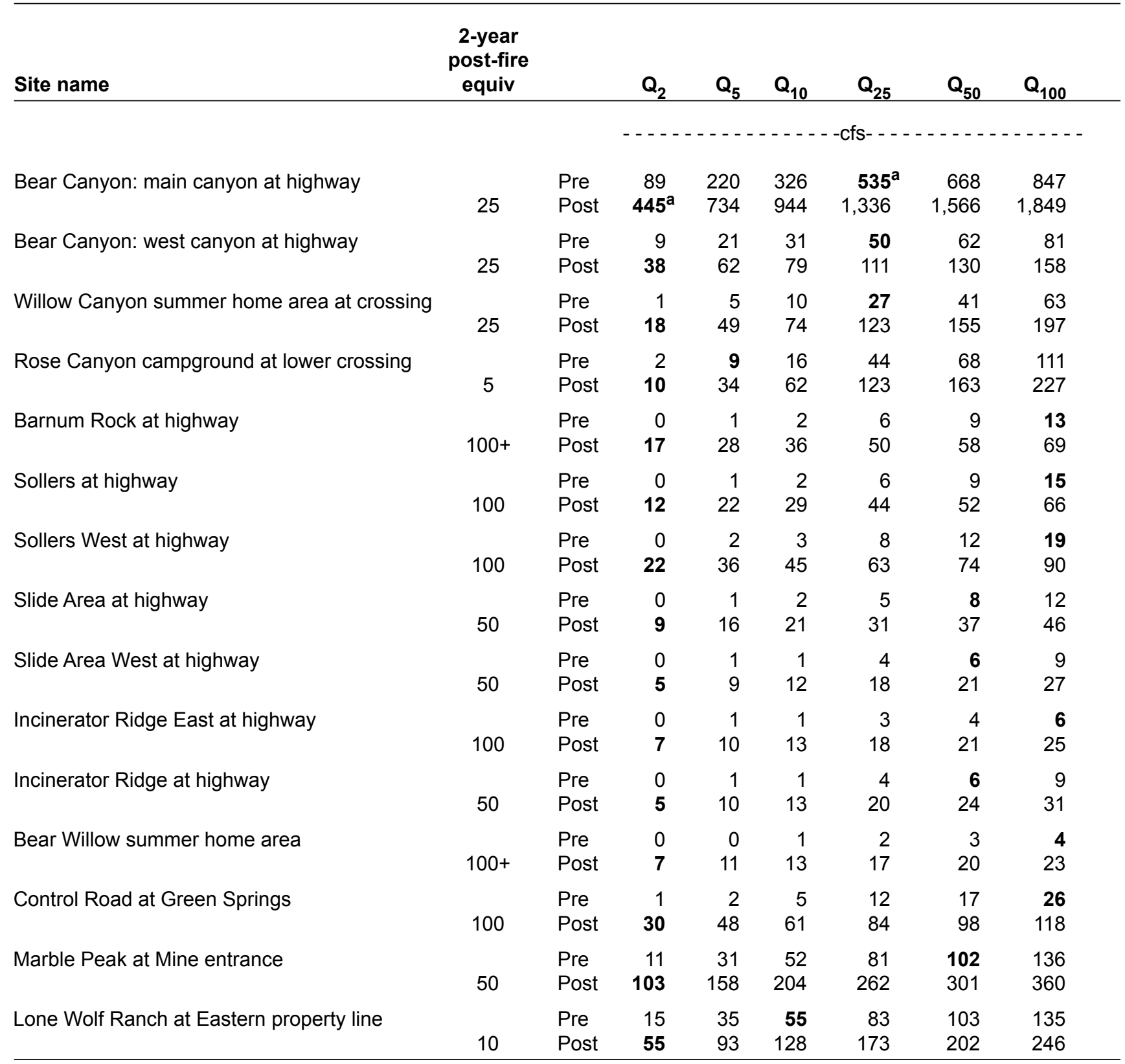

${ }^{a}$ Bold numbers represent similar peakflows. For example, a 2-year post-fire, peakflow (445 cfs) is equivalent to a 25 -year, pre-fire peakflow (535 cfs).

generation, infiltration theory, hydrology, soil physics, plant science, hydraulics, and erosion mechanics (Flanagan and Livingston 1995). The Forest Service WEPP (FS WEPP) Interfaces were developed by the U.S. Forest Service's Rocky Mountain Research Station, Soil and Water Engineering Research Work Unit, Moscow, Idaho (Elliot 2007). They are user-friendly, online tools for various forest applications, and consist of the following individual interfaces:

- Cross Drain: Predicts sediment yield from a road segment across a buffer.

- Rock:Clime: Creates and downloads a WEPP climate file.

- WEPP:Road: Predicts erosion from insloped or outsloped forest roads. 
- WEPP:Road Batch: Predicts erosion from multiple insloped or outsloped forest roads.

- Disturbed WEPP: Predicts erosion from rangeland, forestland, and forest skid trails.

- Erosion Risk Management Tool (ERMiT): Predicts the probability associated with a given amount of soil erosion in each of 5 years following wildfire, and estimates effectiveness of various hillslope treatments.

- WEPP FuME (Fuel Management): Predicts soil erosion associated with fuel management practices, including prescribed fire, thinning, and a road network, and compares that prediction with erosion from wildfire.

\section{Input Requirements}

To use the ERMiT, the following information is required (fig. 14):

- climate

- soil texture, chosen among clay loam, silt loam, sandy loam, and loam

- rock content

- vegetation type, chosen among forest, range, and chaparral

- range/chaparral pre-fire community description, which can be defined by users if "range" or "chaparral" is selected for vegetation type

- hillslope gradient, which consists of top gradient, middle gradient, and toe gradient (the top and toe gradients each represent $10 \%$ of the hillslope length and the middle gradient represents $80 \%$ of the hillslope length)

- hillslope horizontal length

- soil burn severity, chosen among high, moderate, and low.

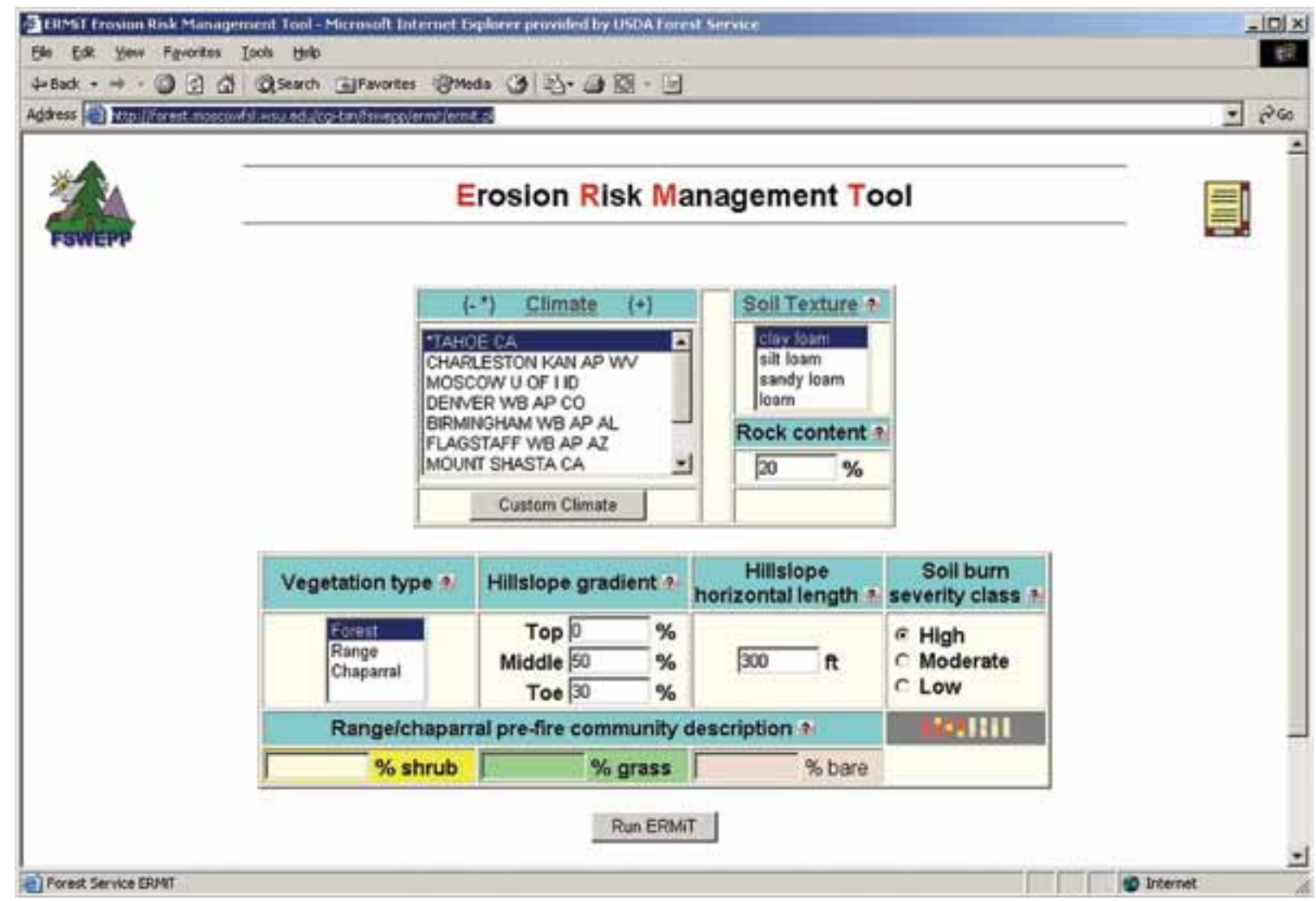

Figure 14-ERMiT input screen (http://forest.moscowfsl.wsu.edu/cgi-bin/fswepp/ermit/ermit.pl). 


\section{Program Availability}

The ERMiT is run from the web site (http://forest.moscowfsl.wsu.edu/ fswepp/). Users can type and choose input information, and run ERMiT. The ERMiT reports rainfall event rankings and characteristics (including runoff), the exceedance probability associated with sediment delivery, and mitigation treatment comparisons (e.g., untreated, seeding, mulching with application rate of $0.5,1,1.5$, and 2 ton/acre, erosion barriers, and contour-felled logs/straw wattles) (fig. 15).

\section{Advantages}

The following were advantages to applying the ERMiT for post-fire runoff and erosion estimation. ERMIT:

- is applicable for estimating post-fire erosion up to 5 years after the fire;

- identifies the damaging storm, which is often a short duration (less than 1 hour), high intensity storm;

- provides various outputs, such as the exceedance probability;

- is suitable for evaluating the effectiveness of various hillslope treatments (e.g., seeding, mulching, erosion barriers, and contour-felled logs/straw wattles);

- is user-friendly, easy to use, and on-line accessible;

- is process-based (i.e., applicable to any part of the United States and to other countries as long as the required climate information is available); and

- uses both English and metric units.

\section{Disadvantages}

The following were disadvantages to applying the ERMiT for post-fire runoff and erosion estimation. ERMIT does not:

- estimate post-fire peak flow, so it is not adequate for prescribing post-fire road treatments;

- provide pre-fire runoff and erosion information, so it cannot compare preand post-fire changes;

- consider post-fire debris flow/torrent; and

- consider watershed shapes and assumes a rectangular hillslope, so ERMiT is difficult to apply for post-fire conditions at a watershed scale $\left(>2 \mathrm{mi}^{2}\right)$.

Recent developments now allow WEPP simulations using digital sources of information with Geographic Information Systems (GIS). This GIS wizard is called GeoWEPP (http://www.geog.buffalo.edu/ rensch/geowepp/), and it has been under development for forest conditions since about 2002 with funding from the Joint Fire Science Program (Renschler 2003; Renschler 2008). GeoWEPP will allow BEAR team members to model pre- and post-fire conditions at a watershed scale. See the GeoWEPP web site for current status of the program.

\section{Example}

The WEPP model was run to estimate 20 years of the pre- and post-fire runoff and erosion potential for the Red Eagle Fire in 2006. The results show more runoff events with greater risks of flood and erosion (table 21). The WEPP model predicted a dramatic increase in the number of rainfall and snowmelt runoff events from 2 and 0 for pre-fire conditions to 79 and 14 for post-fire conditions. 


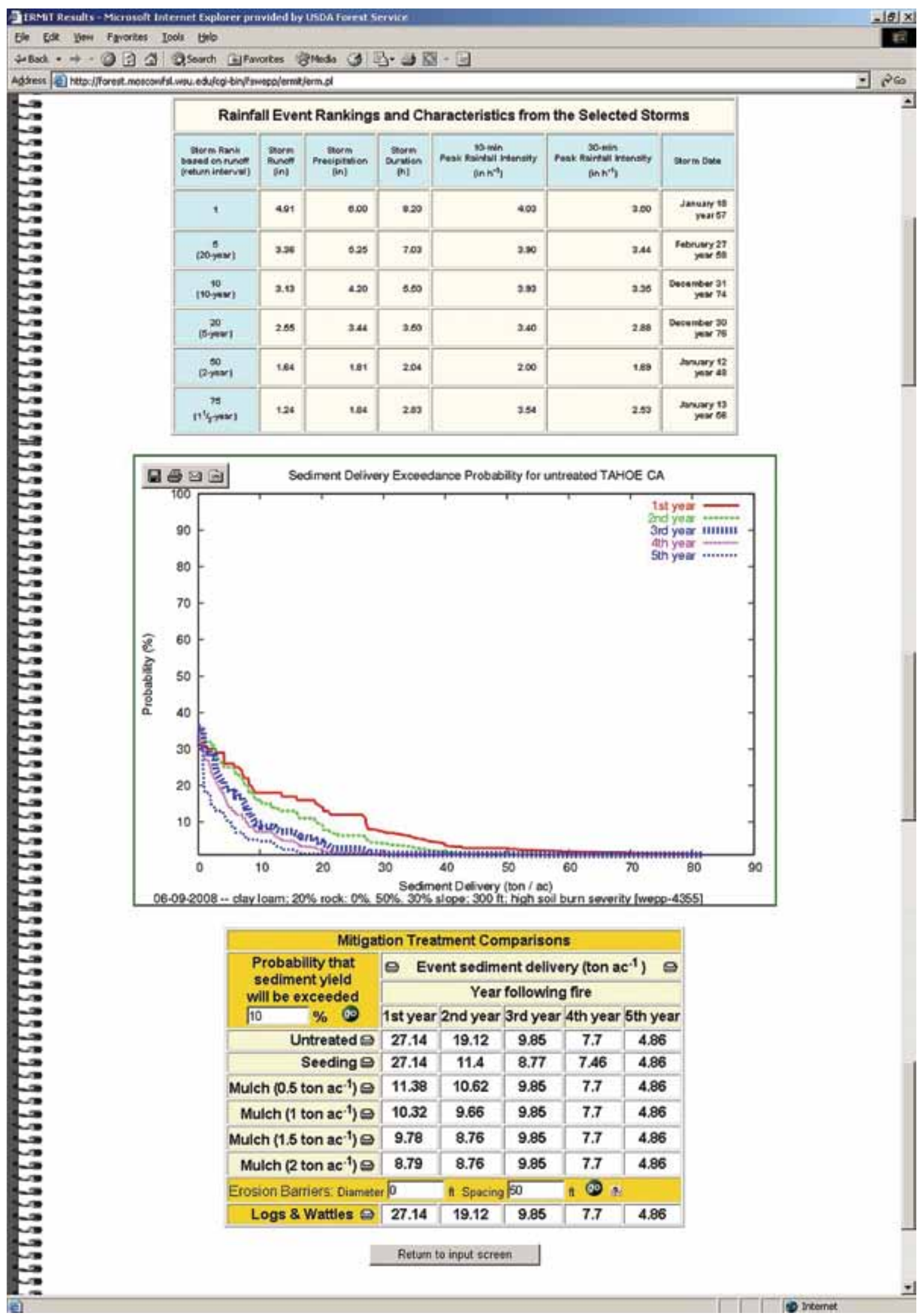

Figure 15-ERMiT output screen. It reports rainfall event rankings and characteristics (including runoff), the exceedance probability associated with sediment delivery, and mitigation treatment comparisons. 
Table 21-Runoff and erosion estimation using the WEPP model for the 2006 Red Eagle Fire, Montana (Sirucek and others 2006).

\begin{tabular}{lcccc}
\hline & Runoff & Soil erosion & Number of rainfall events & Number of snowmelt events \\
\hline & (inch) & $\left(\right.$ tons ac ${ }^{-1}$ ) & & \\
Pre-fire conditions & 0.18 & 0.04 & 2 & 0 \\
Post-fire conditions & 3.08 & 127 & 79 & 14 \\
\hline
\end{tabular}

\section{Fire-Enhanced Runoff and Gully Initiation (FERGI) model}

The FERGI model is used by $2 \%$ of the BAER team members in Region 4 (table 8).

The FERGI model was developed by the U.S. Forest Service, Rocky Mountain Research Station, Boise Aquatic Science Lab and is based on several scientific research papers (Istanbulluoglu and others 2002; Istanbulluoglu and others 2003; Istanbulluoglu and others 2004; Luce 2005; Luce and others 2005; Rajagopalan and Lall 1999; Rhodes 2005; Shakesby and others 2000). The FERGI model is a physically based mathematical description of hillslope hydrologic and geomorphic response to a set of weather events, and the model is applicable to any part of the western United States. FERGI estimates the probability of post-fire rainfall excess ( $\mathrm{mm})$, runoff generation amount $\left(\mathrm{m}^{3} \mathrm{~s}^{-1} \mathrm{~m}^{-1}\right)$, and gully initiation positions $(\mathrm{m})$ on hillslopes with and without mitigations using contour felled logs/log barriers.

\section{Input Requirements}

To use the FERGI model, the following information is required:

- location of three nearest weather stations selected from the FERGI input screen

- depth to water repellent layer, the proportion of the area that is underlain by water repellent soils after a fire

- fractional water repellency

- saturated hydraulic conductivity

- slope

- hillslope length, average length of hillslope before flow begins to accumulate into channels

- $\mathrm{D}_{50}$ of soil surface

- storage capacity of barriers, the amount of precipitation that can be stored by the barriers (i.e., the volume of water storage behind barriers divided by the total area over which the measured barriers are applied)

- fraction of area trenched, the total length of scalping times the width of scalped area divided by the total area of the site

\section{Program Availability}

The FERGI model is accessible from the Forest Service intranet (http:// frames.nbii.gov/fergi/) and run online. Users follow three steps to run the FERGI model: (1) zoom to the area of interest, (2) select each of the three weather stations (fig. 16), and (3) enter soil and hillslope parameters (fig. 17). 


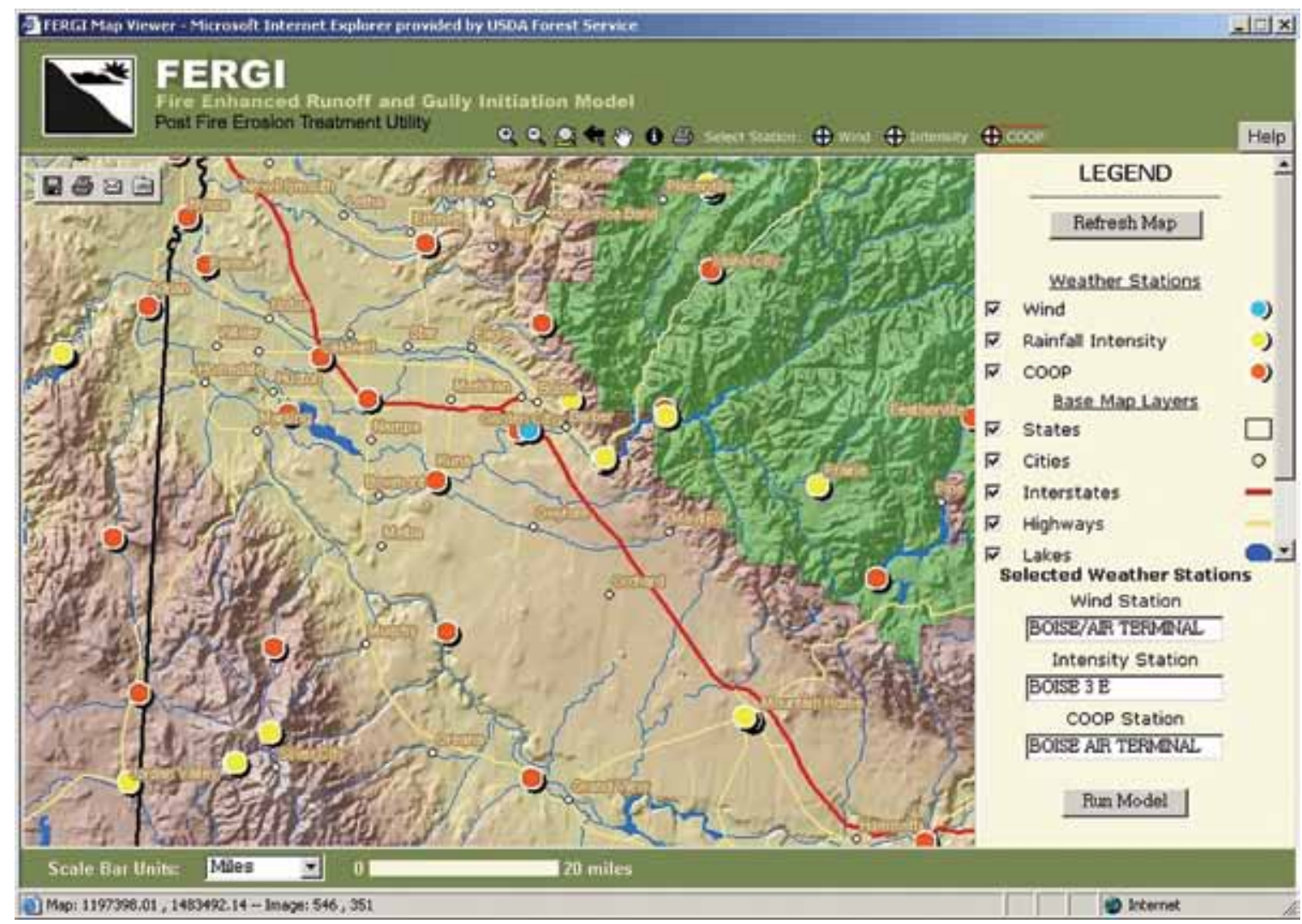

Figure 16-FERGI weather input screen.

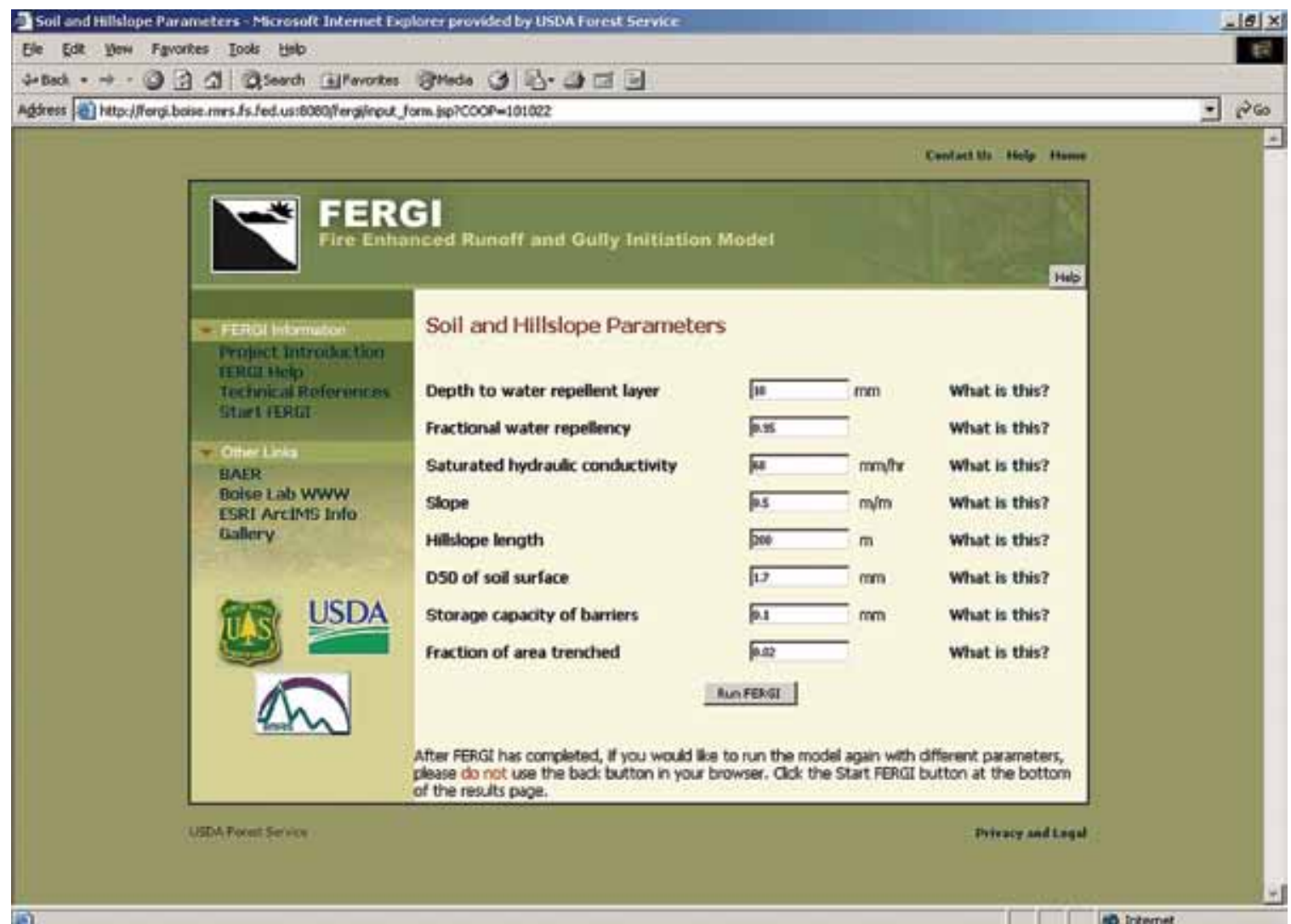

Figure 17-FERGI soil and hillslope input screen. 
The FERGI model reports the following (fig. 18):

- return interval (yrs; from 1 to 100 years)

- rainfall excess no treatment (mm)

- rainfall excess treatment (mm)

- rainfall excess reduction (\%)

- hillslope runoff no treatment $\left(\mathrm{m}^{3} \mathrm{~s}^{-1} \mathrm{~m}^{-1}\right)$

- hillslope runoff treatment $\left(\mathrm{m}^{3} \mathrm{~s}^{-1} \mathrm{~m}^{-1}\right)$

- hillslope runoff reduction (\%)

- gully head no treatment (m)

- gully head treatment (m)

- gully head reduction (\%)

This output is provided as graphs (\% reduction of rainfall excess, hillslope runoff, and gully length) (fig. 18) and tables of text file.

\section{Advantages}

The following were advantages to applying the FERGI for post-fire runoff and erosion estimation. FERGI:

- estimates rainfall excess, post-fire runoff, and gully length of a rectangular strip;

- provides an estimate of the effectiveness of contour felled logs/log barriers as a function of storm return periods;

- is on-line accessible; and

- is process-based, and applicable to the western United States.

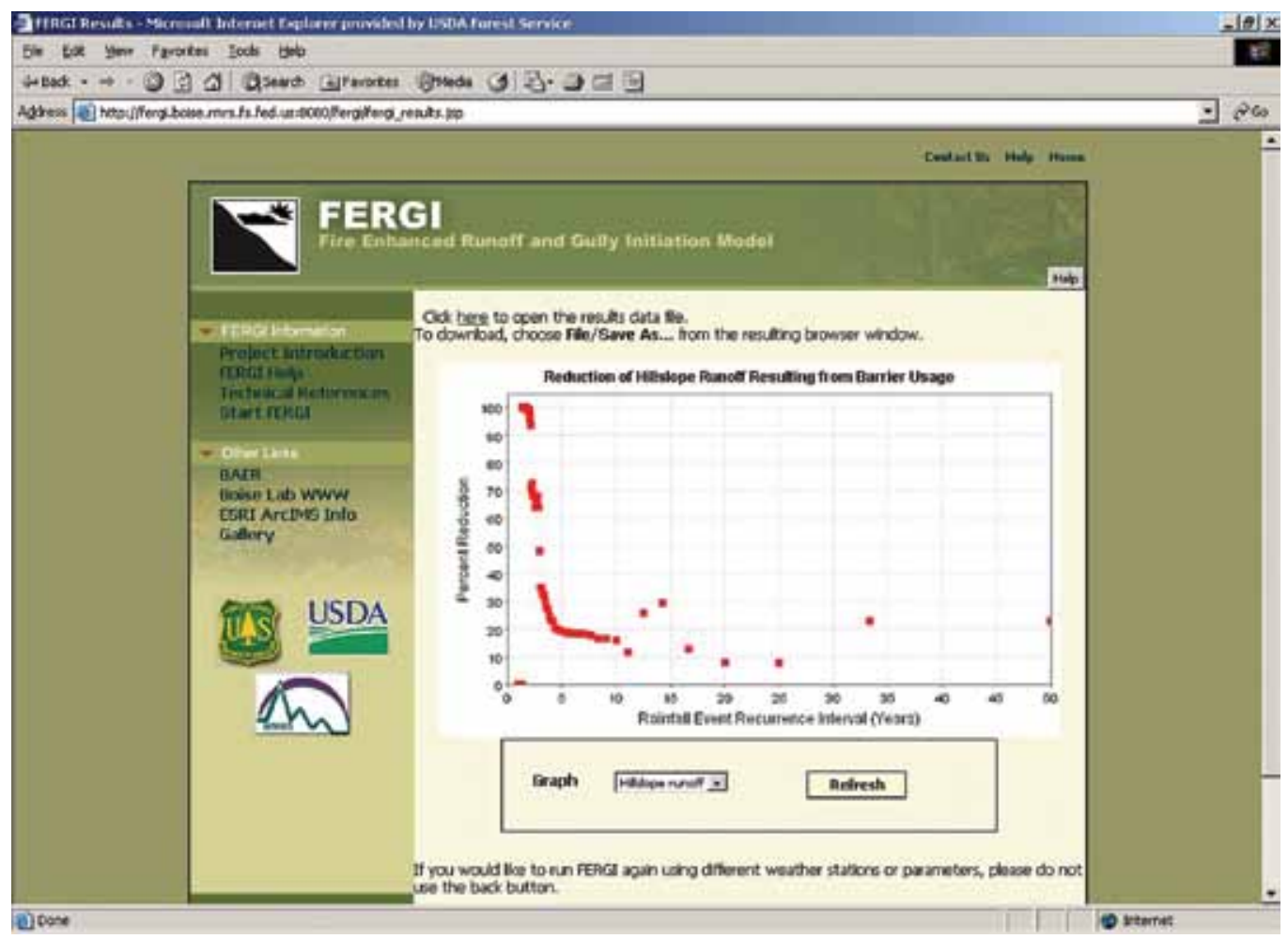

Figure 18-FERGI output as hillslope runoff graph. Usage of contour felled logs/log barriers is mostly effective for small rainfall recurrence interval (less than 5 years). 


\section{Disadvantages}

The following were disadvantages to applying the FERGI for post-fire runoff and erosion estimation. FERGI:

- does not provide pre-fire rainfall excess, runoff amount, and gully initiation positions so users cannot compare pre- and post-fire changes;

- does not estimate erosion;

- does not consider post-fire debris flow/torrent;

- is available only for Forest Service intranet;

- requires detailed soil parameter information;

- does not consider watershed shapes and assumes a rectangular hillslope;

- considers only 24-hour storm duration, so it is not applicable to the regions where the damaging storm duration is much shorter, such as 15 or 30 minutes; and

- uses metric units only.

\section{Watershed Response Model for Forest Management (WATBAL)}

The WATBAL program has been used by $2 \%$ of the BAER team members in Region 1 (table 8).

WATBAL originated from the Northern Region's Water Yield Guidelines, also known as R1/R4 Guidelines (Haupt and others 1976), to establish water yields in response to cumulative watershed development and vegetation manipulation and recovery over time. WATBAL was written in FORTRAN and has evolved using up-to-date methodologies, research findings, and locally derived water/sediment data. WATBAL is currently designed to simulate the potential and most likely effects of primary forest management practices (e.g., timber harvest, road development, and fire) on the responses of watershed and water resources systems with regard to stream flow and sediment regimes (Jones 2005). There are three functional elements in the program:

- a water yield model that uses response functions correlated to land characteristics and forest practices that were taken from the Hydrologic Simulation Model of the Colorado Subalpine Forest (Leaf and Brink 1973) and calibrated for the Northern Rocky Mountains;

- a sediment yield procedure based on surface erosion that incorporates the concepts and methodologies for the Idaho Batholith physiographic regions and associated lands (Cline and others 1981); and

- a sediment yield procedure based on mass erosional processes that was developed on the Clearwater National Forest (Jones 2005).

A typical WATBAL watershed input data file and watershed output response summary report is shown in figures 19 and 20.

\section{Advantages}

The following were advantages to applying the WATBAL for post-fire runoff and erosion estimation.

- WATBAL is applicable for estimating stream flow (e.g., annual and peak runoff and time to peak) and sediment regime effects of forest management practices, including timber harvest, road development, and fire on watersheds. 
d2.efk_big_bear

corralled bear gis query, photo ra dates

east fork big bear down to schwartz

$\begin{array}{rlllllll}22007 \text { A } 19225 & 5.7 & 4840 & 2760 & 3320 & 2800 & 50\end{array}$

$11-\mathrm{A} 47 \quad 25 \quad 614$

11-A47 $30 \quad 145$ EF Big Bear Creek

11-A47 $40 \quad 20$ EF Big Bear Creek

22-A00 25 174 EF Big Bear Creek

22-A00 $30 \quad 246$ EF Big Bear Creek

22-A00 $40 \quad 17$ EF Big Bear Creek

22-A06 25 1023 EF Big Bear Creek

22-A06 $30 \quad 671$ EF Big Bear Creek

22-A06 $40 \quad 45$ EF Big Bear Creek

22-GOI $30 \quad 25$ EF Big Bear Creek

22-GOI 40266 EF Big Bear Creek

$22-00140 \quad 0 \quad$ EF Big Bear Creek

22-U25 $30 \quad 226$ EF Big Bear Creek

22-U25 $40 \quad 60$ EF Big Bear Creek

24-G10 $30 \quad 65$ EF Big Bear Creek

24-G10 40 0 EF Big Bear Creek

24-G20 30193 EF Big Bear Creek

24-G20 40 162 EF Big Bear Creek

24-S10 $40 \quad 40$ EF Big Bear Creek

24-S20 $30 \quad 1$ EF Big Bear Creek

24-S20 40 256 EF Big Bear Creek

$24-S 2530 \quad 1$ EF Big Bear Creek

$24-\mathrm{S} 2540 \quad 219$ EF Big Bear Creek

24-T11 $30 \quad 50$ EF Big Bear Creek

24-T25 25 18 EF Big Bear Creek

24-T25 $30 \quad 508$ EF Big Bear Creek

31-K10 40 95 EF Big Bear Creek

$31-K 2040208$ EF Big Bear Creek

$31-Q 2025 \quad 0$ EF Big Bear Creek

31-Q20 30 O EF Big Bear Creek
84

061218 megfoltz

$17-06-03-06-05-15-40$

50

Figure 19-Typical WATBAL watershed input data file format (Foltz, 2008 USDA Forest Service). Adding input data requires understanding of the program and the natural hydrologic and erosional processes.

- The Clearwater National Forest continues to monitor watersheds. Based on the monitoring data, the model is continuously calibrated, validated, and calibrated again and is believed to be relatively accurate.

\section{Disadvantages}

The following were disadvantages to applying WATBAL for post-fire runoff and erosion estimation. WATBAL:

- is only applicable to Central and Northern Rocky Mountains for water yield (annual and peak runoff), the Idaho Batholith physiographic region for sediment yield from surface erosion, and Clearwater National Forest in the southern Idaho Batholith for sediment yield from landslides;

- does not consider post-fire debris flow/torrent;

- works best in watersheds of 4 to $40 \mathrm{mi}^{2}$, tends to over predict sediment in watersheds smaller than $4 \mathrm{mi}^{2}$ and under-predicts sediment in watersheds greater than $40 \mathrm{mi}^{2}$ (Jones 2005).

- is not user-friendly; and

- uses English units only. 


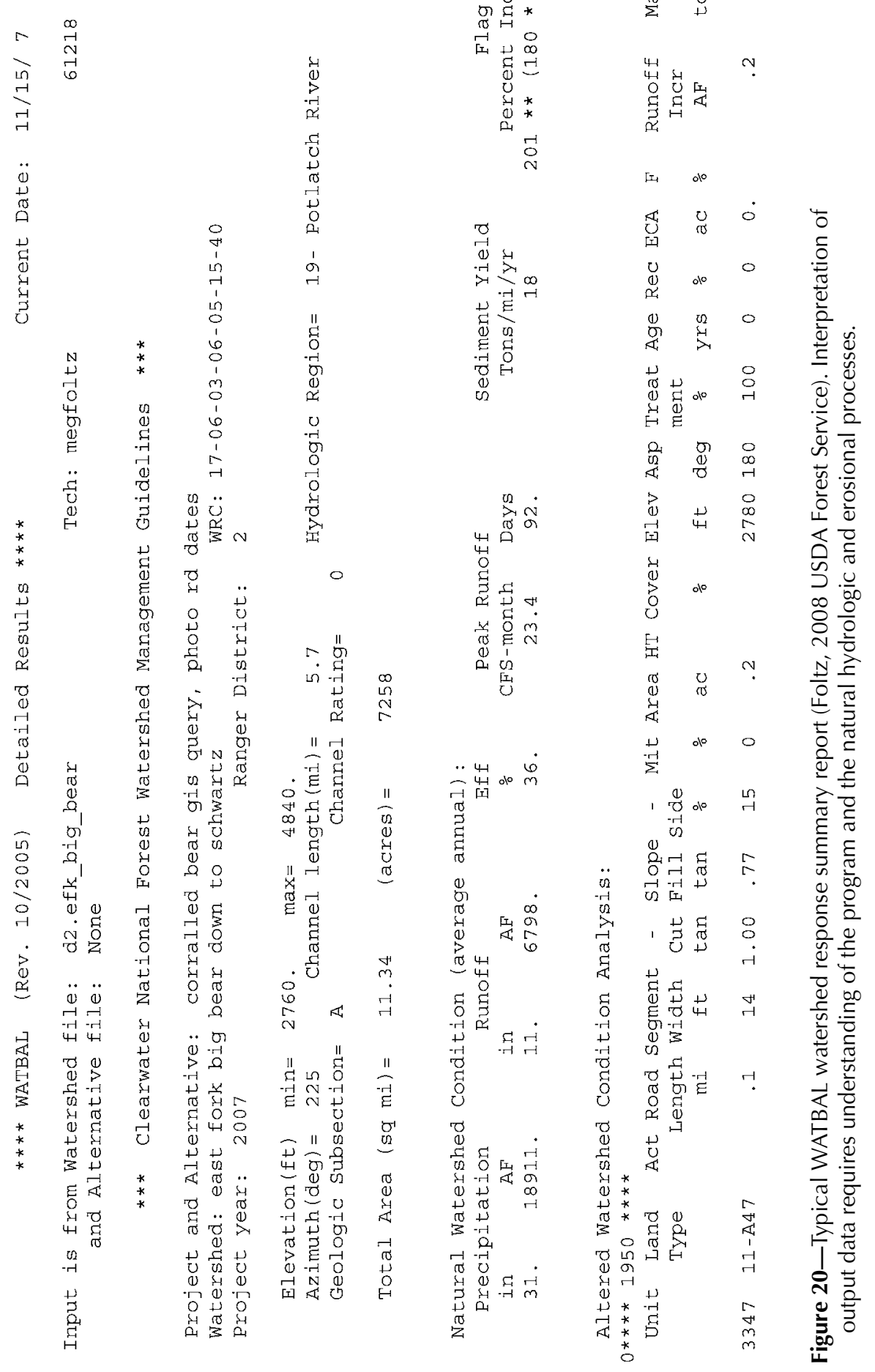


Table 22-Pre- and post-fire WATBAL comparison for the 2000 Crooked Fire in the Clearwater National Forest, Idaho, based on fire perimeter as of August 28, 2000. All values are percent increase over baseline condition (Jones 2000).

\begin{tabular}{|c|c|c|c|c|c|c|c|c|}
\hline \multirow[b]{2}{*}{ Watershed } & \multicolumn{4}{|c|}{ Pre-fire } & \multicolumn{4}{|c|}{ Post-fire } \\
\hline & Sed $^{a}$ & $\mathbf{Q}_{\mathrm{aa}}{ }^{\mathbf{b}}$ & $Q_{p k}{ }^{c}$ & $T_{p k}{ }^{d}$ & Seda & $\mathbf{Q}_{\mathrm{aa}}{ }^{\mathbf{b}}$ & $Q_{p k}{ }^{c}$ & $T_{p k}{ }^{d}$ \\
\hline & \multicolumn{4}{|c|}{ - - - - - - - - - - - - - - - - } & \multicolumn{4}{|c|}{ - - - - - - - - - - - - - - - } \\
\hline Haskell & $48^{\mathrm{e}}$ & 8 & 8 & 9 & 104 & 15 & 16 & 17 \\
\hline Rock & 31 & 5 & 5 & 5 & 295 & 18 & 20 & 19 \\
\hline Pack & 9 & 9 & 9 & 10 & 9 & 9 & 9 & 10 \\
\hline Lower Crooked & 14 & 5 & 5 & 6 & 109 & 15 & 16 & 17 \\
\hline Crooked@ mouth & 7 & 2 & 2 & 3 & 22 & 3 & 3 & 4 \\
\hline 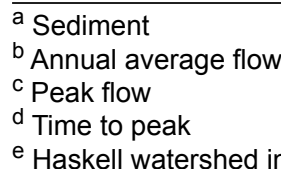 & re con & arodt & s $48 \%$ & & & & & \\
\hline
\end{tabular}

\section{Example}

The Crooked Fire occurred on the Clearwater National Forest in July 28, 2000. WATBAL was used to estimate post-fire sediment and peak flow increases. The pre- and post-fire WATBAL comparison is shown in table 22.

\section{Baer Road Treatments}

BAER specialists have been using various road treatments to increase flow and debris flow capacity of road drainage structures due to wildland fires. Depending on regional climate and fire regimes, different road treatments were preferred. Napper (2006) describes implementation details of most of these treatments, including primary use, description, purpose, suitable sites, cost, and construction specifications. The most commonly used road treatments and their popularity by BAER specialists are shown in table 9. A description and discussion of these treatments follow.

\section{Armored ford crossing}

An armored ford crossing prevents stream diversion and keeps water in its natural channel; prevents erosion of the road fill and reduces adverse effects to water quality; and maintains access to areas once storm runoff rates diminish. Only a small fraction of BAER specialists recommended armored ford crossing.

\section{Channel debris cleaning}

Channel debris cleaning involves removing organic debris and sediment deposits from above the culvert to prevent them from becoming mobilized in debris flows or flood events. Channel debris cleaning is not frequently recommended by BAER specialists.

\section{Culvert inlet/outlet armoring/modification}

The culvert inlet/outlet is often armored to protect the culvert inlet and fillslope. Culverts are modified to increase the flow and debris passage capacity to prevent road damage. Flared/winged metal end sections are often attached for these purposes, especially in California. Only a very small fraction of BAER specialists recommended these treatments. Culvert modification is not commonly recommended by the BAER specialists in the other areas. 


\section{Culvert removal}

Culvert removal uses each Forest's guidelines for culvert hydraulic capacity to determine if a replacement is necessary in the post-fire environment. If vehicle access is not needed, temporary culvert removal is often an option until the area stabilizes. Culvert removal is frequently recommended by Regions 3 and 6 BAER specialists.

\section{Culvert risers}

Culvert risers help prevent the culvert from plugging with sediment and floating debris. The risers allow sediment to accumulate while allowing the water to flow through the culvert. This storage of water and sediment also reduces the peak flows. Only Region 5 BAER specialists recommended culvert risers on a small number of occasions.

\section{Culvert upgrading}

Culvert upgrading relies on each Forest's guidelines for both hydraulic capacity and aquatic species passage to determine if a culvert should be replaced with one of a larger size. Given the values at risk, the culvert upgrading must be designed and implemented to maintain vehicle access and protect aquatic resources. Culvert upgrading is the second most frequently recommended BAER road treatment. Flow capacity of typical culverts in forestlands is shown in table 23 .

Table 23-Flow capacity for circular and pipe-arch culverts (Robison and others 1999).

\begin{tabular}{|c|c|c|c|c|c|}
\hline \multicolumn{3}{|c|}{ Circular culverts $^{a}$} & \multicolumn{3}{|c|}{ Pipe-arch culverts $^{a}$} \\
\hline Diameter & $\begin{array}{l}\text { Cross-section } \\
\text { area culvert }\end{array}$ & $\begin{array}{l}\text { Maximum flow } \\
\text { in culvert }\end{array}$ & Span $\times$ Rise & $\begin{array}{c}\text { Cross-section } \\
\text { area culvert }\end{array}$ & $\begin{array}{c}\text { Maximum flow } \\
\text { in culvert }\end{array}$ \\
\hline (inches) & $\left(\mathrm{ft}^{2}\right)$ & (cfs) & (ft and/or inches) & $\left(\mathrm{ft}^{2}\right)$ & (cfs) \\
\hline 15 & 1.2 & 3.5 & $22 " \times 13^{\prime \prime}$ & 1.6 & 4.5 \\
\hline 18 & 1.8 & 5 & $25^{\prime \prime} \times 16^{\prime \prime}$ & 2.2 & 7 \\
\hline 21 & 2.4 & 8 & $29^{\prime \prime} \times 18^{\prime \prime}$ & 2.9 & 10 \\
\hline 24 & 3.1 & 11 & $36^{\prime \prime} \times 22^{\prime \prime}$ & 4.3 & 16 \\
\hline 27 & 4 & 15 & $43^{\prime \prime} \times 27^{\prime \prime}$ & 6.4 & 26 \\
\hline 30 & 4.9 & 20 & $50 " \times 31 "$ & 8.5 & 37 \\
\hline 33 & 5.9 & 25 & $58 "$ × 36" & 11.4 & 55 \\
\hline 36 & 7.1 & 31 & $65^{\prime \prime} \times 40^{\prime \prime}$ & 14.2 & 70 \\
\hline 42 & 9.6 & 46 & $72^{\prime \prime} \times 44^{\prime \prime}$ & 17.3 & 90 \\
\hline 48 & 12.6 & 64 & $6^{\prime}-1^{\prime \prime} \times 4^{\prime}-7^{\prime \prime}$ & 22 & 130 \\
\hline 54 & 15.9 & 87 & $7^{\prime}-0^{\prime \prime} \times 5^{\prime}-1^{\prime \prime}$ & 28 & 170 \\
\hline 60 & 19.6 & 113 & $8^{\prime}-2^{\prime \prime} \times 5^{\prime}-9^{\prime \prime}$ & 38 & 240 \\
\hline 66 & 23.8 & 145 & $9^{\prime}-6^{\prime \prime} \times 6^{\prime}-5^{\prime \prime}$ & 48 & 340 \\
\hline 72 & 28.3 & 178 & $11^{\prime}-5^{\prime \prime} \times 7^{\prime}-3^{\prime \prime}$ & 63 & 470 \\
\hline 78 & 33.2 & 219 & $12^{\prime}-10^{\prime \prime} \times 8^{\prime}-4^{\prime \prime}$ & 85 & 650 \\
\hline 84 & 38.5 & 262 & $15^{\prime}-4^{\prime \prime} \times 9^{\prime}-3^{\prime \prime}$ & 107 & 930 \\
\hline 90 & 44.2 & 313 & & & \\
\hline 96 & 50.3 & 367 & & & \\
\hline 102 & 56.7 & 427 & & & \\
\hline 108 & 63.6 & 491 & & & \\
\hline 114 & 70.9 & 556 & & & \\
\hline 120 & 78.5 & 645 & & & \\
\hline 132 & 95 & 840 & & & \\
\hline 144 & 113.1 & 1,000 & & & \\
\hline
\end{tabular}

\footnotetext{
a Typical case of ditch relief culvert on forest lands was assumed, which is that the culvert is inlet-controlled, and projecting inlet and headwater depth is equal to diameter or height of culvert.
} 


\section{Debris/trash rack}

A debris/trash rack is a barrier across the stream channel that is used to stop debris too large to pass through a culvert. Debris/trash racks are designed for small and medium floating debris. The storage area upstream from the debris/ trash rack should be large enough to accumulate the anticipated size and quantity of debris, and be accessible for clean-out equipment. Only Regions 3 and 5 BAER specialists recommended debris/trash racks frequently, whereas other Regions only occasionally recommended them.

\section{Ditch cleaning/armoring}

Ditches are cleaned to prevent culvert plugging and armored to prevent erosion from the ditch bed. Many BAER specialists considered ditch cleaning/ armoring as an efficient road treatment and, consequently, frequently recommended it.

\section{Hazard/warning sign}

Hazard/warning signs inform the public of potential hazards created by the fire, including flooding, falling rock, and debris. Stocking hazard/warning signs for immediate use in advance of the fire season is useful.

\section{Outsloping road}

An outsloped road design disperses water along the fillslope and can reduce erosion. Outsloping is often combined with other road treatments such as rolling dip and armored ford crossing. Outsloping is not frequently recommended by BAER specialists.

\section{Relief culvert}

An additional relief culvert is sometimes used to increase the flow capacity of water and debris for an existing culvert. A relief culvert is not frequently recommended by BAER specialists.

\section{Road closure}

A road closure is intended to prevent unacceptable degradation of critical natural or cultural resources or downstream values. Region 3 BEAR specialists considered a road closure as an alternative to other road treatments to protect road users in the event of flash flooding. However, road closure is generally not liked by the public. A road closure is seldom recommended.

\section{Road decommissioning}

Road decommissioning is intended to restore natural hillslope and reduce degradation of natural resources and downstream values. It is seldom recommended; however, it is a viable treatment in cases where roads are either not part of the classified road system or have gone through a process (usually including public involvement) that clears restrictions for decommissioning. Classified roads are not eligible for road decommissioning using BAER funds. There are five levels of treatments for road decommissioning: (1) block entrance, (2) revegetation and waterbarring, (3) remove fill and culverts, (4) establish drainage ways and remove unstable road shoulders, and (5) full obliteration, recontouring, and restoring natural slopes (USDA Forest Service 2003). If road decommissioning is prescribed in BAER, it is usually at the level of full recontouring. 


\section{Rolling dip/water bar}

A rolling dip/water bar is used to drain water effectively from the road surface and reduce the concentration of flow. A rolling dip/water bar also provides a relief valve when a culvert is plugged. Often, a rolling dip/water bar is armored and it is used instead of a culvert upgrade because of its relatively low cost. Rolling dip/water bar is the most frequently recommended road treatment by BAER specialists.

However, a rolling dip/water bar may erode away with strong currents in high discharge. Tables 24 and 25 show the permissible velocity (1) in a bare channel and (2) in a vegetated channel to withstand erosion. The dipped road surface must be able to withstand these flow velocities.

The overflow discharge over an embankment, such as a drain dip located in the fill over a culvert, can be estimated using the weir formula in equation 5 .

$$
Q=C b H^{3 / 2}
$$

Where:

$$
\begin{aligned}
& Q=\text { discharge over an embankment, in } \mathrm{m}^{3} \mathrm{~s}^{-1} \\
& C=\text { sill coefficient, in } \mathrm{m}^{1 / 2} \mathrm{~s}^{-1} \\
& b=\text { length of the flow section in } \mathrm{m} \\
& H=\text { total head upstream of the sill in } \mathrm{m}
\end{aligned}
$$

The coefficient of $C$ is a function of $h / L$ ( $h$ is the head over a sill of width $L$ ) for free flow conditions, whereas a correction factor, $f$, as a function of $h_{d / s} / H$ ( $h_{d / s}$ is the head drop of a sill to downstream), may be incorporated in equation 5 for submerged flow conditions (Novak and others 2001).

Table 24-Permissible velocity to withstand erosion (Watkins and Fiddes 1984; Novak and others 2001).

\begin{tabular}{lcc}
\hline Surface type & $\mathbf{5 0}$ percentile size & Permissible velocity \\
\hline & $(\mathrm{mm})$ & $\left(\mathrm{m} \mathrm{s}^{-1}\right)$ \\
Fine silt & - & 0.25 to 0.8 \\
Sandy clay of low density & - & 0.4 \\
Coarse silt, fine sand & 0.05 & \\
Fine sand (non-colloidal) & 0.25 & 0.6 \\
Sandy loam (non-colloidal) & - & 0.7 \\
Sandy clay of medium density & - & 0.8 \\
Silt loam & - & \\
Medium sand & 1.0 & 1.0 \\
Dense clay & - & \\
Volcanic ash & - & 1.5 \\
Coarse sand & 2.5 & \\
Stiff clay & - & 1.6 \\
Graded loam to cobbles & - & 1.1 \\
Alluvial silt (colloidal) & - & 1.4 \\
Graded silt to cobbles (colloidal) & - & 1.9 \\
Gravel (medium to fine) & 5.0 & 2.4 \\
Gravel (coarse to medium) & 10 & 3.6 \\
Coarse gravel and cobbles & 25 & 6.0 \\
Cobbles & 40 & 7.0 \\
Cobbles & 100 & - \\
Bitumen-bound macadam & - & \\
Asphalt & & \\
\hline a Type of road construction. It consists of three layers of stones that interlock each other. &
\end{tabular}


Table 25—Permissible velocities in vegetated channels (Watkins and Fiddes 1984).

\begin{tabular}{lccc}
\hline & & \multicolumn{2}{c}{ Permissible velocities } \\
\cline { 3 - 4 } Vegetation & \% slope of drain & In stable soils & In erodible soils \\
\hline & & $-2 .-1.4$ & 1.8 \\
Bermuda grass & 0 to 5 & 2.4 & 1.5 \\
(Cynodon dactylon) & 5 to 10 & 2.1 & 1.5 \\
Buffalo grass & 0 to 5 & 1.8 & 1.2 \\
(Buchloe dactyloides) & 5 to 10 &
\end{tabular}

Table 26-Range of values of $C$ for free flow or modular flow over the embankment (Novak and others 2001).

\begin{tabular}{lcc}
\hline Surface type & Range of $\mathbf{h} / \mathbf{L}$ & Range of $\mathbf{C}$ \\
\hline Paved surface & 0.15 & 1.68 \\
& 0.20 & 1.69 \\
Gravel surface & $>0.25$ & 1.70 \\
& 0.15 & 1.63 \\
& 0.20 & 1.66 \\
& 0.25 & 1.69 \\
\hline
\end{tabular}

Table 27-Correction factor, $f$, for submerged flow or non-modular flow (Novak and others 2001).

\begin{tabular}{lcc}
\hline Surface type & Range of $\boldsymbol{h}_{\boldsymbol{d l s} \mathbf{s}} \mathbf{l}$ & $\boldsymbol{f}$ \\
\hline Paved surface & $\leq 0.80$ & 1.00 \\
& 0.90 & 0.93 \\
& 0.95 & 0.80 \\
Gravel surface & 0.99 & 0.50 \\
& $\leq 0.75$ & 1.00 \\
& 0.80 & 0.98 \\
& 0.90 & 0.88 \\
& 0.95 & 0.68 \\
& 0.98 & 0.50
\end{tabular}

Free flow occurs where a man-made structure creates a drop in water level over the structure resulting in the major part of the total upstream energy head being converted into kinetic energy to obtain critical flow at the control section. Under this condition, the upstream head is independent of downstream conditions.

The opposite of free flow is submerged flow. With submerged flow, the drop in water level over the structure is small and the flow above it remains subcritical. Therefore, the upstream head is affected by downstream conditions (Boiten 2002). Either of these flow conditions is possible in forest conditions. The range of values for $C$ and $f$ are shown in tables 26 and 27.

\section{Storm patrol}

A storm patrol keeps culvert and drainage structures functional by cleaning sediment and debris from the inlet between or during storm events. It is an efficient measure to protect the transport infrastructure after a wildfire and provides needed road access throughout the designated storm season by ensuring road drainage function.

\section{Gray Literature From BAER Interviews}

From BAER interviews, we obtained various gray literature (i.e., unpublished reports, file reports, or hard to find proceeding papers). Table 28 lists and categorizes the gray literature. This section contains a summary of beneficial information related to post-fire runoff and erosion estimation methods, road treatments, and post-fire monitoring reports. The opinions and values in the following summaries are those of the gray literature authors and not necessarily those of this report's authors. In a few instances, italicized comments reflect what we believed necessary to clarify or correct comments in the gray literature. 


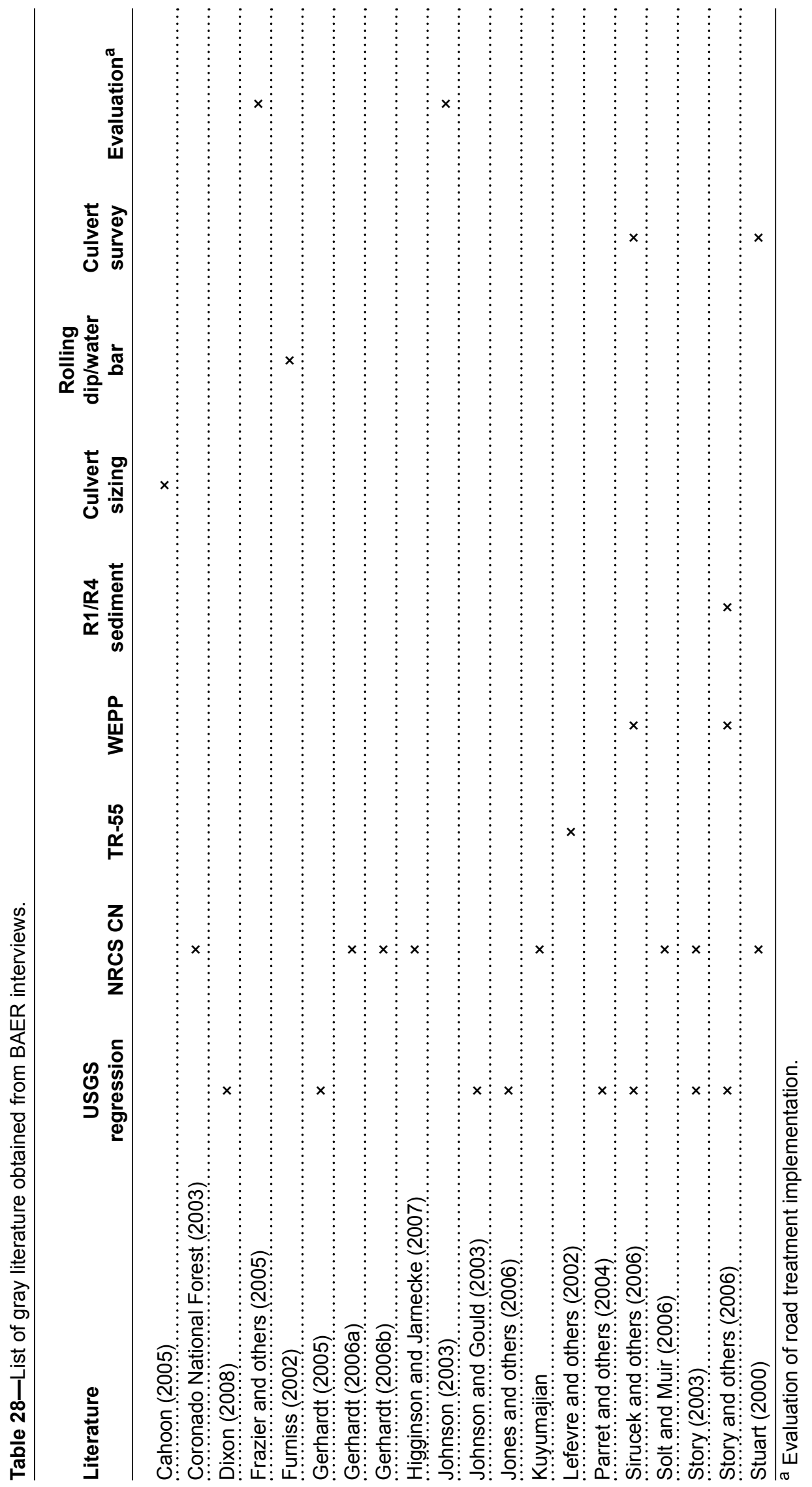




\section{USGS regression methods}

Parrett, Charles; Cannon, Susan H.; Pierce, Kenneth L. 2004. Wildfire-related floods and debris flows in Montana in 2000 and 2001. Water-Resources Investigations Report 03-4319. Denver, CO: U.S. Geological Survey. 22 p.

Following extensive wildfires in summer 2000, flooding and debris flow occurred in three different burned areas in Montana on the Canyon Ferry, Ashland, and Bitterroot Fires (fig. 21).

Approximately 40,000 acres were burned through September in the Canyon Ferry area. Fires included Canyon Ferry Complex and Boulder Complex (Montana Department of Commerce 2003). A U.S. Geological Survey rain gage recorded a 5- to 10-year return period, 15-minute duration event on July 17 on Crittenden Gulch. The resulting measured flow had a pre-fire 200-year return interval. Details of precipitation and peak streamflow discharges are shown in tables 29 and 30 .

Approximately 60,000 acres were burned in the Ashland area. Fires included Pease Fire (Montana Department of Commerce 2003). The U.S. Geological Survey rain gage recorded a 100- to 500-year return period, 5-minute duration event on June 30 at a site (site 33) near the center of the Ashland area (table 31). Recurrence intervals for calculated peak stream discharges, based on unburned conditions, were 50 to 100 years at three sites and greater than 500 at five sites (table 32).

The Bitterroot area was the most active of the 2000 fire season and included six different fire complexes, including Valley Complex, Mussigbrod Complex, Skalkaho Complex, Wilderness Complex, Middle Fork Complex, and Blodgett Trailhead. More than 400,000 acres were burned in the Bitterroot area (Montana Department of Commerce 2003). A series of thunderstorms in July 2000 caused flooding and debris flows on small streams. The U.S. Geological Survey rain gage recorded multiple 10- to 25- year return period, 5- to 30-minute duration events on June 15, 20, and 21 . The resulting flows had an estimated pre-fire recurrence interval of 200 to 500 years. Details of precipitation and peak streamflow discharges are shown in tables 33 to 35 .

Figure 21-Location of three burned areas in Montana: A. Canyon Ferry, B. Ashland, and C. Bitterroot (Parrett and others 2004).
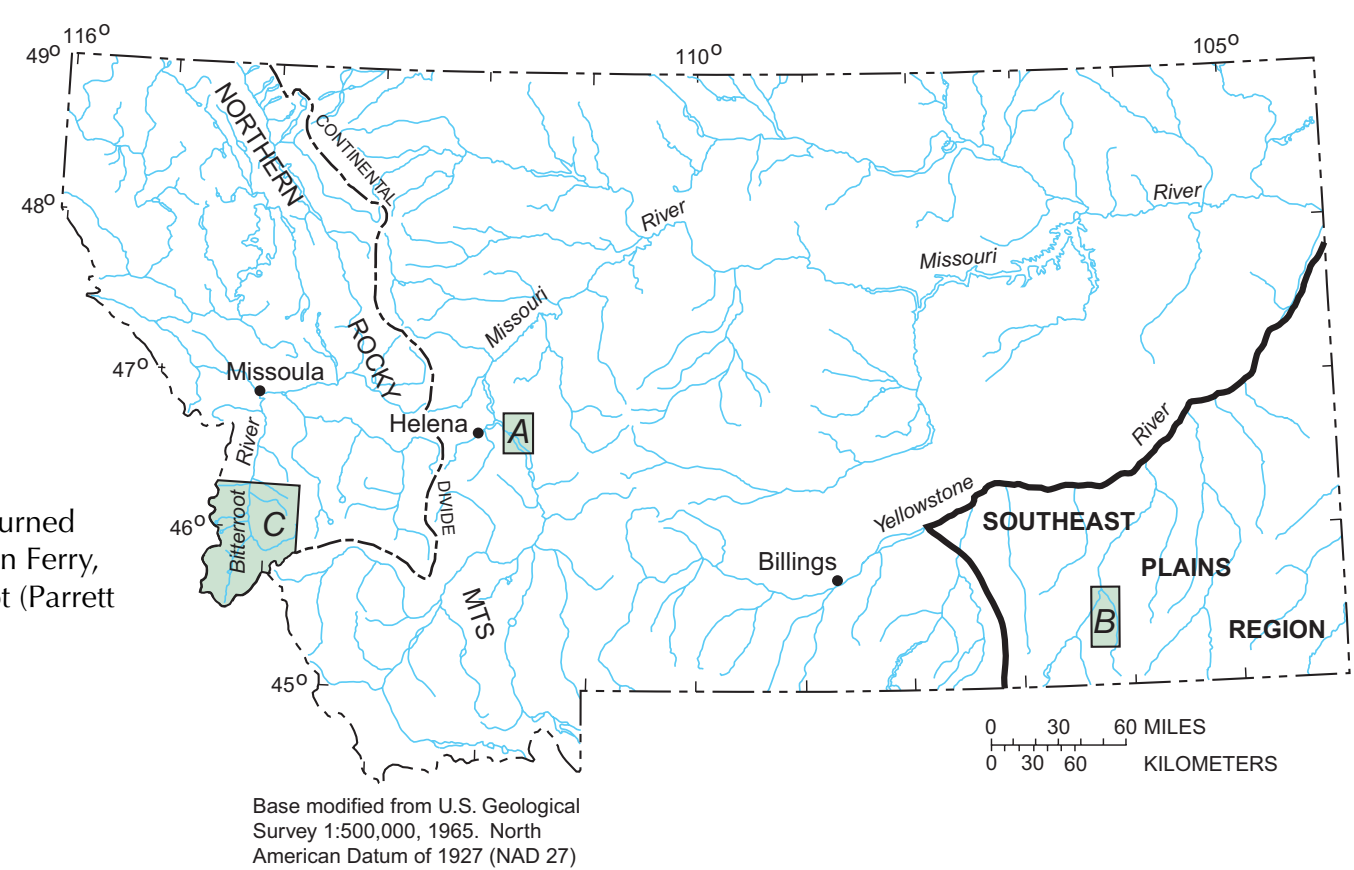
Table 29_Data from significant precipitation storm events during 2001 at U.S. Geological Survey precipitation stations in Canyon Ferry area, Montana (Parrett and others 2004).

\begin{tabular}{|c|c|c|c|c|c|}
\hline \multicolumn{6}{|c|}{$\begin{array}{l}\text { Crittenden Gulch } \\
\text { (site 27) }\end{array}$} \\
\hline \multicolumn{3}{|c|}{$7 / 17$} & \multicolumn{3}{|c|}{$7 / 30$} \\
\hline $\begin{array}{c}\text { Storm } \\
\text { duration }\end{array}$ & $\begin{array}{l}\text { Maximum } \\
\text { rain depth }\end{array}$ & $\begin{array}{l}\text { Recur. } \\
\text { interval }\end{array}$ & $\begin{array}{c}\text { Storm } \\
\text { duration }\end{array}$ & $\begin{array}{l}\text { Maximum } \\
\text { rain depth }\end{array}$ & $\begin{array}{l}\text { Recur. } \\
\text { interval }\end{array}$ \\
\hline (minute) & (inch) & (year) & (minute) & (inch) & (year) \\
\hline 5 & 0.17 & 5 & 5 & 0.02 & $<2$ \\
\hline 10 & 0.27 & 5 & 10 & 0.04 & $<2$ \\
\hline 15 & 0.36 & 5 to 10 & 15 & 0.06 & $<2$ \\
\hline 30 & 0.41 & 2 to 5 & 30 & 0.12 & $<\overline{2}$ \\
\hline 60 & 0.43 & 2 to 5 & 60 & 0.15 & $<2$ \\
\hline Daily total & 0.70 & $<2$ & Daily total & 0.28 & $<2$ \\
\hline \multicolumn{3}{|c|}{$\begin{array}{c}\text { Upper Magpie Creek } \\
\text { (site 29) } \\
7 / 17\end{array}$} & \multicolumn{3}{|c|}{$\begin{array}{c}\text { Lower Magpie Creek } \\
\text { (site 30) } \\
7 / 17\end{array}$} \\
\hline $\begin{array}{c}\text { Storm } \\
\text { duration }\end{array}$ & $\begin{array}{l}\text { Maximum } \\
\text { rain depth }\end{array}$ & $\begin{array}{l}\text { Recur. } \\
\text { interval }\end{array}$ & $\begin{array}{c}\text { Storm } \\
\text { duration }\end{array}$ & $\begin{array}{l}\text { Maximum } \\
\text { rain depth }\end{array}$ & $\begin{array}{c}\text { Recur. } \\
\text { interval }\end{array}$ \\
\hline (minute) & (inch) & (year) & (minute) & (inch) & (year) \\
\hline 5 & 0.13 & 2 & 5 & 0.07 & $<2$ \\
\hline 10 & 0.18 & $<2$ & 10 & 0.10 & $<2$ \\
\hline 15 & 0.21 & $<2$ & 15 & 0.12 & $<2$ \\
\hline 30 & 0.30 & $<2$ & 30 & 0.19 & $<2$ \\
\hline 60 & 0.35 & $<2$ & 60 & 0.23 & $<2$ \\
\hline Daily total & 0.58 & $<2$ & Daily total & 0.39 & $<2$ \\
\hline
\end{tabular}

Table 30-Peak streamflow discharges and estimated recurrence interval during 2001 at U.S. Geological Survey streamflow-gaging stations in Canyon Ferry area, Montana (Parrett and others 2004).

\begin{tabular}{|c|c|c|c|c|c|}
\hline $\begin{array}{l}\text { Station or } \\
\text { stream name }\end{array}$ & $\begin{array}{l}\text { Drainage } \\
\text { area }\end{array}$ & $\begin{array}{c}\text { Precip. } \\
\text { station } \\
\text { site number }\end{array}$ & $\begin{array}{c}\text { Date of } \\
\text { peak } \\
\text { discharge }\end{array}$ & $\begin{array}{c}\text { Peak } \\
\text { discharge }\end{array}$ & $\begin{array}{c}\text { Estimated } \\
\text { recur. } \\
\text { interval }^{\mathrm{a}}\end{array}$ \\
\hline & $\left(\mathrm{mi}^{2}\right)$ & & & (cfs) & (year) \\
\hline \multirow{2}{*}{$\begin{array}{l}\text { Crittenden Gulch at mouth, } \\
\text { near Helena }\end{array}$} & 2.3 & 27 & $7 / 17$ & $1,020^{b}$ & 200 \\
\hline & 2.3 & 27 & $7 / 31$ & $60^{\mathrm{b}, \mathrm{c}}$ & 5 to 10 \\
\hline $\begin{array}{l}\text { Magpie Creek above Bar Gulch, } \\
\text { near Helena }\end{array}$ & 17.4 & $29 / 30^{d}$ & $7 / 17$ & 405 & 50 to 100 \\
\hline $\begin{array}{l}\text { Hellgate Gulch at Forest Service } \\
\text { boundary, near Helena }\end{array}$ & 9.2 & 30 & $7 / 17$ & $310^{c}$ & 100 to 200 \\
\hline
\end{tabular}

Table 31-Data from significant precipitation storm events during 2001 at U.S. Geological Survey precipitation stations in Ashland area, Montana (Parrett and others 2004).

\begin{tabular}{cccccc}
\hline \multicolumn{3}{c}{$\begin{array}{c}\text { Upper Paget Creek } \\
\text { (site 33) } \\
\text { 6/30 }\end{array}$} & & & \multicolumn{3}{c}{$\begin{array}{c}\text { Coal Bank Creek } \\
\text { (site 34) } \\
\mathbf{6 / 3 0}\end{array}$} \\
\cline { 1 - 2 } $\begin{array}{c}\text { Storm } \\
\text { duration }\end{array}$ & $\begin{array}{c}\text { Maximum } \\
\text { rain depth }\end{array}$ & $\begin{array}{c}\text { Recur. } \\
\text { interval }\end{array}$ & $\begin{array}{c}\text { Storm } \\
\text { duration }\end{array}$ & $\begin{array}{c}\text { Maximum } \\
\text { rain depth }\end{array}$ & $\begin{array}{c}\text { Recur. } \\
\text { interval }\end{array}$ \\
\hline (minute) & (inch) & (year) & (minute) & (inch) & (year) \\
5 & 0.56 & 100 to 500 & 5 & 0.14 & $<2$ \\
10 & 0.75 & 25 to 50 & 10 & 0.28 & $<2$ \\
15 & 086 & 25 & 15 & 0.29 & $<2$ \\
30 & 0.95 & 10 & 30 & 0.29 & $<2$ \\
60 & 0.96 & 5 & 60 & 0.29 & $<2$ \\
Daily total & 0.96 & $<2$ & Daily total & 0.29 & $<2$ \\
\hline
\end{tabular}


Table 32-Peak streamflow discharges and estimated recurrence interval during 2001 at U.S. Geological Survey streamflow-gaging stations in Ashland area, Montana (Parrett and others 2004).

\begin{tabular}{|c|c|c|c|c|c|}
\hline $\begin{array}{l}\text { Station or } \\
\text { stream name }\end{array}$ & $\begin{array}{l}\text { Drainage } \\
\text { area }\end{array}$ & $\begin{array}{l}\text { Precip. } \\
\text { station site } \\
\text { number }\end{array}$ & $\begin{array}{c}\text { Date of } \\
\text { peak } \\
\text { discharge }\end{array}$ & $\begin{array}{c}\text { Peak } \\
\text { discharge }\end{array}$ & $\begin{array}{c}\text { Estimated } \\
\text { recur. } \\
\text { interval }^{\mathrm{a}}\end{array}$ \\
\hline & $\left(m i^{2}\right)$ & & & (cfs) & (year) \\
\hline Home Creek near Ashland & 35.4 & 33 & $6 / 30$ & $1,000^{b}$ & 50 to 100 \\
\hline Newell Creek near Ashland & 4.3 & 33 & $6 / 30$ & 400 & 50 to 100 \\
\hline Chromo Creek near Ashland & 5.2 & 33 & $6 / 30$ & 1,220 & $>500$ \\
\hline Brain Creek near Ashland & 8.0 & 33 & $6 / 30$ & 3,200 & $>500$ \\
\hline $\begin{array}{c}\text { Paget Creek near Fort Howes } \\
\text { Ranger Station, near Otter }\end{array}$ & 14.0 & 33 & $6 / 30$ & 3,500 & $>500$ \\
\hline Hole-in-the-Wall Creek near Ashland & 1.5 & 34 & $6 / 30$ & 310 & 50 to 100 \\
\hline Dry Creek near Ashland & 4.5 & 33 & $6 / 30$ & 2,460 & $>500$ \\
\hline King Creek near Ashland & 12.4 & 33 & $6 / 30$ & 1,920 & $>500$ \\
\hline
\end{tabular}

a Based on equations developed for ungaged sites in unburned areas by Parrett and Johnson (2004).

b Estimated discharge

Gerhardt, Nick. 2005. [Personal notes]. September 2. China 10-Flow calculations using USGS regression method.

- assume that peak flow occurs in spring runoff, not fall storm flow

- 10-year, 24-hour storm = 2.8 inches (Miller and others 1973b)

- use 10-year peak flow for Peasley Creek from Kjelstorm and Moffat (1981) $=11.9 \mathrm{cfsm}$ for pre-fire condition

- assume a two-fold 1st year post-fire runoff increase for moderate/high burn severity from Robichaud (2000)

- calculate the area of different burn severities as follows:

Area of burn $\quad=122$ acres for high burn

$$
\text { \} } 714 \text { acres }=1.12 \mathrm{mi}^{2}=41 \%
$$

$=592$ acres moderate burn

$=254$ acres for low burn

\} 1050 acres $=1.64 \mathrm{mi}^{2}=59 \%$

$=796$ acres unburned

$$
2.76 \mathrm{mi}^{2}
$$

- Calculate post-fire peak flow based on a 10-year, 24-hour storm as follows:

Peak flow from high $/$ moderate burn severity $=23.8 \mathrm{cfsm} \times 41 \%=9.76 \mathrm{cfsm}$

Peak flow from low burn severity/unburned $\quad=11.9 \mathrm{cfsm} \times 59 \% \quad=7.02 \mathrm{cfsm}$

$16.78 \mathrm{cfsm}$

Jones, Richard; Mital, Jim. 2003. Burned area report, Beaver Lakes Complex. 11 p.

Jones, Richards [and others]. 2006. Burned area report, Gash Creek Incident. 13 p.

For design storm analysis, a 15-minute, 25-year storm was used that occurred in Sleeping Child Creek on July 15, 2001 (Parrett and others 2004; table 33). The storm produced $200 \mathrm{cfs}$ over a $1.8 \mathrm{mi}^{2}$ burned watershed, resulting in 110 cfsm, which was greater than a 500-year runoff event (Parrett and others 2004; table 34). This watershed was selected for the design storm since the runoff 
Table 33-Data from significant precipitation storm events during 2001 at U.S. Geological Survey precipitation stations in Bitterroot area, Montana (Parrett and others 2004).

\section{Laird Creek at mouth}

(site 3)

$7 / 20$

\begin{tabular}{ccc}
\hline $\begin{array}{c}\text { Storm } \\
\text { duration }\end{array}$ & $\begin{array}{c}\text { Maximum } \\
\text { rain depth }\end{array}$ & $\begin{array}{c}\text { Recur. } \\
\text { interval }\end{array}$ \\
\hline (minute) & (inch) & (year) \\
5 & 0.12 & 2 \\
10 & 0.24 & 5 \\
15 & 0.31 & 5 \\
30 & 0.42 & 2 to 5 \\
60 & 0.43 & 2 to 5 \\
Daily total & 0.44 & $<2$ \\
\hline
\end{tabular}

$7 / 21$

\begin{tabular}{ccc}
\hline $\begin{array}{c}\text { Storm } \\
\text { duration }\end{array}$ & $\begin{array}{c}\text { Maximum } \\
\text { rain depth }\end{array}$ & $\begin{array}{c}\text { Recur. } \\
\text { interval }\end{array}$ \\
\hline $\begin{array}{c}\text { (minute) } \\
5\end{array}$ & (inch) & (year) \\
10 & 0.16 & 5 \\
15 & 0.31 & 10 \\
30 & 0.47 & 10 to 25 \\
60 & 0.54 & 10 \\
Daily total & 0.58 & 5 to 10 \\
\end{tabular}

Laird Creek above Gilbert Creek

(site 5)

$7 / 20$

\begin{tabular}{|c|c|c|c|c|c|c|}
\hline $\begin{array}{c}\text { Storm } \\
\text { duration }\end{array}$ & $\begin{array}{l}\text { Maximum } \\
\text { rain depth }\end{array}$ & $\begin{array}{l}\text { Recur. } \\
\text { interval }\end{array}$ & & $\begin{array}{c}\text { Storm } \\
\text { duration }\end{array}$ & $\begin{array}{l}\text { Maximum } \\
\text { rain depth }\end{array}$ & $\begin{array}{l}\text { Recur. } \\
\text { interval }\end{array}$ \\
\hline (minute) & (inch) & (year) & & (minute) & (inch) & (year) \\
\hline 5 & 0.21 & 10 to 25 & & 5 & 0.15 & 5 \\
\hline 10 & 0.35 & 10 to 25 & & 10 & 0.22 & 2 to 5 \\
\hline 15 & 0.38 & 10 & & 15 & 0.30 & 5 \\
\hline 30 & 0.42 & 2 to 5 & & 30 & 0.35 & 2 to 5 \\
\hline 60 & 0.43 & $<2$ & & 60 & 0.47 & 2 to 5 \\
\hline Daily total & 0.43 & $<2$ & & Daily total & 0.61 & $<2$ \\
\hline \multicolumn{3}{|c|}{$\begin{array}{c}\text { North Rye Creek } \\
\text { (site 7) } \\
7 / 15\end{array}$} & & \multicolumn{3}{|c|}{$\begin{array}{c}\text { Burke Gulch } \\
\text { (site 12) } \\
7 / 30\end{array}$} \\
\hline $\begin{array}{c}\text { Storm } \\
\text { duration }\end{array}$ & $\begin{array}{l}\text { Maximum } \\
\text { rain depth }\end{array}$ & $\begin{array}{l}\text { Recur. } \\
\text { interval }\end{array}$ & & $\begin{array}{c}\text { Storm } \\
\text { duration }\end{array}$ & $\begin{array}{l}\text { Maximum } \\
\text { rain depth }\end{array}$ & $\begin{array}{l}\text { Recur. } \\
\text { interval }\end{array}$ \\
\hline (minute) & (inch) & (year) & & (minute) & (inch) & (year) \\
\hline 5 & 0.22 & 10 & & 5 & 0.04 & $<2$ \\
\hline 10 & 0.35 & 10 to 25 & & 10 & 0.06 & $<2$ \\
\hline 15 & 0.44 & 10 to 25 & & 15 & 0.07 & $<2$ \\
\hline 30 & 0.54 & 10 & & 30 & 0.09 & $<2$ \\
\hline 60 & 0.62 & 5 to 10 & & 60 & 0.12 & $<2$ \\
\hline \multirow[t]{10}{*}{ Daily total } & 0.64 & $<2$ & & Daily total & 0.78 & $<2$ \\
\hline & \multicolumn{4}{|c|}{$\begin{array}{c}\text { Sleeping Child Creek } \\
\text { (site 14) } \\
7 / 15 \\
\end{array}$} & & \\
\hline & & ion & $\begin{array}{l}\text { Maximum } \\
\text { rain depth }\end{array}$ & $\begin{array}{l}\text { Recur. } \\
\text { interval }\end{array}$ & & \\
\hline & & te) & (inch) & (year) & & \\
\hline & & & 0.21 & 5 & & \\
\hline & & & 0.38 & 10 to 25 & & \\
\hline & & & 0.53 & 25 & & \\
\hline & & & 0.66 & 10 to 25 & & \\
\hline & & & 0.76 & 10 & & \\
\hline & & otal & 0.83 & $<2$ & & \\
\hline
\end{tabular}


Table 34-Peak streamflow discharges and estimated recurrence interval during 2001 at U.S. Geological Survey streamflow-gaging stations in Bitterroot area, Montana (Parrett and others 2004).

\begin{tabular}{|c|c|c|c|c|c|}
\hline Station or stream name & $\begin{array}{l}\text { Drainage } \\
\text { area }\end{array}$ & \begin{tabular}{|c|} 
Precip. \\
station \\
site number
\end{tabular} & $\begin{array}{c}\text { Date of } \\
\text { peak } \\
\text { discharge }\end{array}$ & $\begin{array}{c}\text { Peak } \\
\text { discharge }\end{array}$ & $\begin{array}{c}\text { Estimated } \\
\text { recur. } \\
\text { interval }^{\text {a }}\end{array}$ \\
\hline & $\left(m i^{2}\right)$ & & & (cfs) & (year) \\
\hline $\begin{array}{l}\text { Little Sleeping Child Creek above } \\
\text { Spring Gulch, near Hamilton }\end{array}$ & 9.3 & 12 & $7 / 30$ & $35^{\mathrm{b}}$ & 2 \\
\hline \multirow{2}{*}{ Laird Creek near Sula } & \multirow{2}{*}{9.3} & \multirow[b]{2}{*}{3} & $7 / 20$ & $210^{C}$ & 200 to 500 \\
\hline & & & $7 / 21$ & $220^{C}$ & 200 to 500 \\
\hline \multirow{2}{*}{$\begin{array}{l}\text { Laird Creek above Gilbert Creek, near } \\
\text { Sula }\end{array}$} & \multirow{2}{*}{5.1} & \multirow{2}{*}{5} & $7 / 20$ & $160^{\mathrm{C}}$ & 200 to 500 \\
\hline & & & $7 / 21$ & $160^{\mathrm{C}}$ & 200 to 500 \\
\hline North Rye Creek near Conner & 17.5 & 7 & $7 / 15$ & 260 & 100 \\
\hline Burke Gulch near Darby & 6.5 & 12 & $7 / 30$ & 3.3 & $<2$ \\
\hline Sleeping Child Creek near Hamilton & 37.0 & 14 & $7 / 15$ & 150 & $<2$ \\
\hline $\begin{array}{l}\text { Unnamed tributary to Sleeping Child } \\
\text { Creek at Hot Springs, near Hamilton }\end{array}$ & 3.6 & 14 & $7 / 15$ & 10 & 2 \\
\hline $\begin{array}{l}\text { Unnamed tributary No. } 7 \text { to Sleeping } \\
\text { Child Creek near Hamilton }\end{array}$ & 1.8 & 14 & $7 / 15$ & $200^{d}$ & $>500$ \\
\hline
\end{tabular}

${ }^{a}$ Based on equations developed for ungaged sites in unburned areas by Parrett and Johnson (2004).

${ }^{b}$ Peak discharge from storm of September 30 to October 1, 2000, was 190 cfs with recurrence interval of 100 years.

${ }^{\mathrm{c}}$ Multiple peak flows from thunderstorms

${ }^{\mathrm{d}}$ Estimated discharge

Table 35-Peak debris-flow discharges on July 15, 2001, at selected tributary sites in the Sleeping Child Creek drainage in Bitterroot area, Montana (Parrett and others 2004).

\begin{tabular}{cccc}
$\begin{array}{l}\text { Unnamed tributary to } \\
\text { Sleeping Child Creek }\end{array}$ & Drainage area & Average channel slope & Estimated peak flow \\
\hline & $\left(\mathrm{mi}^{2}\right)$ & $\left(\mathrm{ft} \mathrm{ft}^{-1}\right)$ & $(\mathrm{cfs})$ \\
No. 2 & 0.07 & 0.43 & 1,740 \\
No. 3 & 0.09 & 0.47 & 1,860 \\
No. 4 & 0.10 & 0.46 & 1,930 \\
No. 5 & 0.28 & 0.31 & 7,860 \\
No. 6 & 0.08 & 0.43 & 3,500 \\
No. 8 & 0.41 & 0.16 & 2,730 \\
\hline
\end{tabular}

did not include debris and the watershed size was small $\left(<2 \mathrm{mi}^{2}\right)$. The burned watershed by the 2003 Beaver Lakes Fire, Idaho, could receive a similar storm and respond similar to Sleeping Child Creek, where burn intensities were high. Storm runoff should be adjusted where burn intensities are less than high. Road drainage structures for a drainage area less than $2 \mathrm{mi}^{2}$ should be designed to handle these flows (110 cfsm or less). For watersheds of 5 to $20 \mathrm{mi}^{2}$, the design storm should be approximately $23 \mathrm{cfsm}$ (Arkell and Richards 1986).

Johnson, Steve; Gould, Jessica. 2003. Burned area emergency stabilization and rehab plan, Blackfoot Complex Fires, Flathead NF, watershed resource assessment. Libby, MT: U.S. Department of Agriculture, Forest Service, Northern Region, Kootenai National Forest. 10 p.

Table 36 shows the burned area acreages by fire severity for selected watersheds associated with Blackfoot Complex as of September 20, 2003. A USGS method based on Omang (1992) was used to estimate 100-year discharges for selected drainages (table 37). To estimate the potential watershed response from these areas, a modifier (flow increase factor) was applied to the USGS predicted pre-fire flow values. The percent of the basin that had either high or moderate 
Table 36-The burned acreages by fire severity associated with the 2003 Blackfoot Complex, Montana as of September 20, 2003 (Johnson and Gould 2003).

\begin{tabular}{|c|c|c|c|c|}
\hline \multirow[b]{2}{*}{ Site name } & \multicolumn{3}{|c|}{ Burn severity area } & \multirow[b]{2}{*}{ Total watershed size } \\
\hline & High & Moderate & Low and unburned & \\
\hline & $\ldots$ & - - - - - - & - - - -acres- - - - - - & $\ldots$ \\
\hline Sullivan & 28,936 & 1,721 & 274 & 30,931 \\
\hline Sullivan below Conner ${ }^{a}$ & 10,131 & 1,695 & 274 & 12,100 \\
\hline Goldie at HH Reservoir ${ }^{b}$ & 1,519 & 835 & 56 & 2,410 \\
\hline Goldie Creek at FR $9838^{C}$ & 935 & 479 & 0 & 1,114 \\
\hline Clayton & 3,840 & 447 & 0 & 4,287 \\
\hline
\end{tabular}

${ }^{a}$ This basin is not enclosed, but analyzed as a unit since this is only part of the Sullivan Creek watershed that was burned.

${ }^{\mathrm{b}}$ Goldie at Hungry Horse reservoir

${ }^{c}$ Goldie Creek at Forest Road 9383

Table 37-Predicted pre- and post-fire, 100 year flows based on Omang (1992) for the 2003 Blackfoot Complex, Montana (Johnson and Gould 2003).

\begin{tabular}{|c|c|c|c|c|}
\hline Site name & Watershed area & $\begin{array}{c}\text { Pre-fire } \\
\text { predicted flow }\end{array}$ & $\begin{array}{c}\text { Flow increase } \\
\text { factor }^{a}\end{array}$ & $\begin{array}{c}\text { Post-fire } \\
\text { predicted flow }\end{array}$ \\
\hline & (acre) & (cfs) & & (cfs) \\
\hline Sullivan & 30,931 & 1,758 & 1.06 & 1,871 \\
\hline Sullivan below Conner ${ }^{b}$ & 12,100 & 716 & 1.16 & 832 \\
\hline Goldie at HH Reservoir ${ }^{\mathrm{C}}$ & 2,410 & 187 & 1.37 & 256 \\
\hline Goldie Creek at FR $9838^{d}$ & 1,114 & 104 & 1.43 & 149 \\
\hline Clayton & 4,287 & 340 & 1.10 & 375 \\
\hline
\end{tabular}

${ }^{a}$ Assuming $1 \%$ increase in flow for every $1 \%$ of the contributing watershed area with high and moderate burn severity

$\mathrm{b}$ This basin is not enclosed, but analyzed as a unit since this is only part of the Sullivan Creek watershed that was burned.

${ }^{\mathrm{c}}$ Goldie at Hungry Horse reservoir

d Goldie Creek at Forest Road 9383

burn severity was used as the modifier (e.g., $37 \%$ of high and moderate burn severity $=1.37$ for modifier).

Sirucek, Dean; Olson, Dennis; Butterfly, Henry; Johnson, Steve. 2006.

Interagency burned area emergency stabilization \& rehabilitation plan, Red Eagle Fire, watershed resource assessment, hydrology and soils. 24 p.

A USGS method based on Parrett and Johnson (2004) was used to estimate design discharges for selected drainages (table 38). To estimate the potential watershed response from these areas, a modifier (flow increase factor) was applied to the USGS predicted pre-fire flow values. The percent of the basin that had either high or moderate burn severity was used as the modifier (e.g., 48.6\% of high and moderate burn severity $=1.486$ for modifier). The modifier was applied to events with return intervals of 25 years or less.

Story, Mark. 2003. [E-mail circulation]. September. Stormflow methods.

For larger watersheds (greater than 5 to $10 \mathrm{mi}^{2}$ ), $\mathrm{CN}$ methods are not appropriate since uniform rainfall distribution within the entire watershed usually results in overestimation of the peak flow. For larger watersheds, the USGS regression equations by Omang (1992) can be used to estimate the pre-fire peak flow. The post-fire peak flow is then approximated by assumptions about postfire water yield increase. On the Skalkaho/Valley Complex Fires in the Bitterroot 
Table 38-Predicted pre- and post-fire flows based on Parrett and Johnson (2004) for the 2006 Red Eagle Fire, Montana (Sirucek and others 2006).

\begin{tabular}{lcccc}
\hline Watershed name & Return interval & $\begin{array}{c}\text { Pre-fire } \\
\text { predicted flow }\end{array}$ & $\begin{array}{c}\text { Flow increase } \\
\text { factor }\end{array}$ & $\begin{array}{c}\text { Post-fire } \\
\text { predicted flow }^{\mathbf{b}}\end{array}$ \\
\hline Divide Creek & (year) & $(\mathrm{cfs})$ & & $(\mathrm{cfs})$ \\
& 2 & 284 & 1.486 & 422 \\
& 5 & 495 & & 914 \\
& 10 & 615 & - & 1,366 \\
Red Eagle Creek & 25 & 919 & - & Same \\
& 50 & 1,308 & 1.253 & Same \\
& 100 & 1,885 & & 1,042 \\
2 & 832 & & 1,619 \\
& 5 & 1,292 & - & 1,882 \\
& 10 & 1,502 & - & 2,616 \\
\end{tabular}

${ }^{a}$ Assuming $1 \%$ increase in flow for every $1 \%$ of the contributing watershed area with high and moderate burn severity

${ }^{b}$ Post-fire flow $=$ Pre-fire flow $\times$ Flow increase factor

National Forest in 2000, it was assumed that high burn severity areas had $1 / 3$ and $1 / 6$ soil water repellencies with a 10 -fold increase in surface runoff at the same year and 1 year after the fire. This procedure can be much more accurate if burned sites are located near gaged sites on the same stream and gaged data is used to estimate pre-fire peak flow. This procedure is also most applicable to longer duration precipitation events and snowmelt runoff events.

Story, Mark; Johnson, Steve; Stuart, Bo; Hickenbottom, Jennifer; Thatcher, Ron; Swartz, Scott. 2006. BAER specialist report, hydrology and roads, Derby Fire. Bozeman, MT: U.S. Department of Agriculture, Forest Service, Northern Region, Gallatin National Forest. 17 p.

The Derby Fire burned 223,570 acres on both the Gallatin and the Custer National Forests in Montana in 2006. Stormflow response recovery is related to the reestablishment of grass/shrubs and, on the Gallatin NF, typically takes 1 to 5 years depending on the burn severity. On the Gallatin NF, most of post-fire peak flow increase was observed up to 2 years after the wildfires (Thompson Creek Fire, 2000; Fridley Fire, 2002). The USGS regression equations from Parrett and Johnson (2004) were adjusted to analyze the potential post-fire flooding caused by the Derby Fires for watersheds greater than 5,000 acres. Pre-fire runoff was modified to estimate post-fire runoff using modifier that was defined as a ratio of post-fire to pre-fire runoff. Since a $100 \%$ peak flow increase was assumed for high and moderate burn severity area, the modifier was $100 \%$ plus the percent of the watershed that was categorized into high and moderate burn severity area. For example, if high and moderate burn severity was $45 \%$, then the modifier was 1.45 . Table 39 shows how to calculate post-fire peak flow using modifier.

Dixon, Mike. 2008. [Personal note on file with author]. March 17. 100 year flood flow culvert analysis. 
Table 39-USGS regression method to calculate post-fire peak flow for large watersheds (>5,000 ac) burned by the 2006 Derby Fire, Montana (Story and others 2006).

\begin{tabular}{|c|c|c|c|c|c|c|c|c|}
\hline \multirow[t]{2}{*}{ Watershed } & $\begin{array}{l}\text { Total } \\
\text { area }\end{array}$ & \multicolumn{2}{|c|}{$\begin{array}{l}\text { High + moderate } \\
\text { burn severity }\end{array}$} & \multirow[t]{2}{*}{ Modifier } & \multirow[t]{2}{*}{ Pre Q10 } & Pre Q25 & Post Q10 & Post Q25 \\
\hline & $-\ldots$ & - - - - & $(\%)$ & & & - . - . & s) $-\ldots$ & - . - . \\
\hline Bad Canyon & 12,239 & 2,685 & 21.9 & 1.219 & 411 & 677 & 501 & 826 \\
\hline Trout Creek & 16,866 & 5,801 & 34.4 & 1.344 & 516 & 877 & 693 & 1179 \\
\hline
\end{tabular}

Table 40-Culvert analysis for 100-year flood flow for Payette National Forest, Idaho using USGS regression method (Dixon 2008).

\begin{tabular}{|c|c|c|c|c|c|c|}
\hline \multirow[b]{2}{*}{ Road number } & \multirow{2}{*}{$\begin{array}{c}\text { Drainage } \\
\text { area }\end{array}$} & \multirow{2}{*}{$\begin{array}{l}\text { Forest } \\
\text { cover }^{a}\end{array}$} & \multicolumn{3}{|c|}{ Thomas and others $^{b}$} & \multirow{2}{*}{$\begin{array}{c}Q \text { and } H^{c} \\
Q_{100}\end{array}$} \\
\hline & & & $\mathbf{Q}_{10}$ & $\mathbf{Q}_{50}$ & $\mathbf{Q}_{100}$ & \\
\hline & $\left(m i^{2}\right)$ & $(\%)$ & \multicolumn{4}{|c|}{ 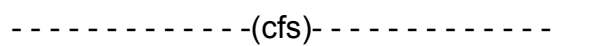 } \\
\hline 50004 & 0.46 & 20 & 24.4 & 36.7 & 43.7 & 42.2 \\
\hline 50004 & 0.56 & 65 & 22.5 & 33.8 & 40.2 & 49.1 \\
\hline 51823 & 0.45 & 65 & 18.6 & 27.9 & 33.2 & 41.5 \\
\hline 51822 & 0.29 & 65 & 12.7 & 19.0 & 22.6 & 29.5 \\
\hline
\end{tabular}

astimated from aerial photo

${ }^{b}$ Thomas and others (1997)

c Quillian and Harenberg (1982)

\section{Curve Number methods}

Gerhardt, Nick. 2006a. [Unpublished report]. June 26. NRCS post-fire stormflow model, step-by-step.

FIRE HYDRO (figs. 9 to 11), an Excel spreadsheet, was developed in 2001 by NRCS in Montana for use in post-fire stormflow runoff precipitation (Cerrelli 2005) using CN methods (USDA SCS 1972; USDA SCS 1991). The following steps were suggested when using FIRE HYDRO.

1. Determine if this is an appropriate model to use.

2. Calculate watershed area (acres).

3. Calculate mean watershed slope.

4. Calculate pre-fire composite runoff Curve Number.

5. Calculate post-fire composite runoff Curve Numbers (year 1, 2, and 3).

6. Look up precipitation input values from NOAA Atlas 2 (Miller and others 1973a).

7. Determine storm type and unit peak flow (from nomographs).

8. Compare results to unit area measured values (Parrett and others 2004).

9. Rerun if necessary.

10. Interpret results. 
Gerhardt, Nick. 2006b. [Unpublished report]. December 18.

Characterization of a post-fire debris flow and flood, Blackerby Fire,

Idaho.

The Blackerby Fire on the Nez Perce National Forest near Grangeville, Idaho, occurred in August, 2005. On 19 May 2006, a 0.79-inch precipitation event with a 30-minute duration occurred over a portion of the burned area. The precipitation event was equivalent to a 25-year, 30-minute storm event as determined from NOAA Atlas 2 (table 41).

The NRCS CN flood flow model results used in the BAER analysis (using FIRE HYDRO) were for a 25-year return event and based on the assumption of limited soil and vegetation regeneration during the first year after the fire (table 42). The observed flood discharge value was $71 \mathrm{cfs}$ or $56 \mathrm{cfsm}\left(\mathrm{cfs} \mathrm{mi}^{-2}\right)$. This observed flood discharge was half that of predicted flow. Additionally, the observed debris flow discharge was $620 \mathrm{cfs}$ or $492 \mathrm{cfsm}$, indicating that debris flow discharge was nearly an order of magnitude greater than the flood discharge (table 43).

Table 41-Local precipitation-frequency values from NOAAAtlas 2 for the 2005 Blackerby Fire, Idaho (Miller and others 1973b; Gerhardt 2006).

\begin{tabular}{|c|c|c|c|}
\hline \multirow[b]{2}{*}{ Return interval } & \multicolumn{3}{|c|}{ Rainfall duration } \\
\hline & 30-minute & 6-hour & 24-hour \\
\hline & \multicolumn{3}{|c|}{ - - - - - - - -inches- - - - - - } \\
\hline 2-year & 0.32 & 0.9 & 1.6 \\
\hline 5-year & 0.47 & 1.1 & 2.0 \\
\hline 10-year & 0.63 & 1.3 & 2.4 \\
\hline 25-year & 0.79 & 1.5 & 2.9 \\
\hline
\end{tabular}

Table 42-NRCS peak flow discharge model output in the second post-fire period, 1 year after the 2005 Blackerby Fire, Idaho (Gerhardt 2006).

\begin{tabular}{ccc}
\hline Return interval & \multicolumn{2}{c}{ Peak flow rate } \\
\hline & $\mathrm{ft}^{3} \mathrm{sec}^{-1}$ & $\mathrm{cfs} \mathrm{mi}^{-2}$ \\
2-year & 23 & 18 \\
5-year & 50 & 40 \\
10-year & 85 & 67 \\
25-year & 138 & 109 \\
\hline
\end{tabular}

Table 43-Observed flood and debris flow on May 19, 2006, 1 year after the 2005 Blackerby Fire, Idaho (Gerhardt 2006).

\begin{tabular}{lcc}
\hline Observed discharge & \multicolumn{2}{c}{ Peak flow rate } \\
\hline & $\mathrm{ft}^{3} \mathrm{sec}^{-1}$ & $\mathrm{cfs} \mathrm{mi}^{-2}$ \\
Flood flow & 71 & 56 \\
Debris flow & 620 & 492 \\
\hline
\end{tabular}

Story, Mark. 2003. [E-mail circulation]. September. Stormflow methods.

For small watersheds (less than $5 \mathrm{mi}^{2}$ ), a simple DOS model developed by Hawkins and Greenberg (1990), WILDCAT4, is useful to estimate post-fire peak flow. The WILDCAT4 is a NRCS CN method program that allows the user to chose from a 15 -minute to a 24-hour storm. A CN of 90 to 95 is appropriate for a high severity burn without water repellent soils and a CN of 93 to 98 is appropriate for a high severity burn and with water repellent soils.

The WILDCAT4 uses a weighted average $\mathrm{CN}$ for a watershed (e-mail circulation, Story 2003) [Author's note: Hawkins (pers. comm. 2008 Univ. of AZ) commented that the WILDCAT4 uses weighted runoffs.]. The WILDCAT4 
tends to have a long time of concentrations $\left(T_{c}\right)$. If a shorter $T_{c}$ is preferred, the user can substitute $T_{c}$ from equation 5 (Dunne and Leopold 1978; US SCS 1972), which will generate a higher peak flow due to a quicker watershed response to the storm events.

$$
T_{c}=\frac{L^{1.15}}{7700 \cdot H^{0.38}}
$$

Where:

$T_{c}=$ time of concentration (hr)

$L=$ length of the catchment along the mainstream from the basin outlet to the most distant ridge (ft)

$H=$ difference in elevation between the basin outlet and the most distant ridge $(\mathrm{ft})$

Storm distributions can be customized into WILDCAT4 program using Arkell and Richards (1986).

For watersheds up to $5 \mathrm{mi}^{2}$ (often $10 \mathrm{mi}^{2}$ ), an NRCS CN method using an Excel spreadsheet, FIRE HYDRO (Cerrelli 2005), is useful for estimating postfire peak flow in Montana. The FIRE HYDRO is applicable for 24-hour rainfall events only and not applicable for short duration rainfall events such as a 1-hour storm or less. Use of FIRE HYDRO for short duration events may result in underestimation of the peak flow.

Stuart, Bo. 2000. Maudlow Fire, Burned Area Emergency Rehabilitation

(BAER) plan. Townsend, MT: U.S. Department of Agriculture, Forest

Service, Northern Region, Helena National Forest.

Snowmelt runoff does not provide peak flow events in the fire area. During June to early September, convective rainstorms have moderate intensity over the fire area. Monsoon type rainfall events in spring and summer pose greatest risk to the watersheds of concern. The NOAA Atlas 2 (Miller and others 1973a) indicated 1.6, 2.0, and 2.4 inches of rainfall for 2-, 5-, and 10-year, 24-hour storms for the Maudlow Fire area. In order to estimate storm event peak flow, an NRCS CN method, FIRE HYDRO (Cerrelli 2005), was used. The SCS Type I rainfall distribution curve (fig. 4) was assumed for unit peak flows. GIS was used to generate watershed acreage, burn severity acres by watershed, and watershed slopes for FIRE HYDRO. Based on observations of unburned conditions, land type/cover type, burn intensity, and water repellency conditions, the $\mathrm{CN}$ ranged from 60 to 64 for unburned areas, 70 to 72 for low burn severity, and 80 for moderate burn severity. There was no high burn severity area in the Maudlow Fire area. Potential peak flow reduction with BAER treatments was modeled by assuming the combination of seeding, contour-felling, fencing, and road drainage would reduce the $\mathrm{CN}$ of a moderate burn severity area to $\mathrm{CN} 75$ and reduce the $\mathrm{CN}$ of a low burn severity area to CN 66. Table 44 shows the results from NRCS, FIRE HYDRO, ranging from $66 \mathrm{cfs}$ in Timber Gulch to $532 \mathrm{cfs}$ in Dry Creek.

Higginson, Brad; Jarnecke, Jeremy. 2007. Salt Creek BAER-2007 Burned

Area Emergency Response. Provo, UT: Unita National Forest; hydrology specialist report. $11 \mathrm{p}$.

The WILDCAT4 (Hawkins and Greenberg 1990) was used to estimate preand post-fire runoff on the 2007 Salt Creek Fire, Utah. Approximately 21,996 acres $\left(34.4 \mathrm{mi}^{2}\right)$ were burned within the fire parameters, whereas 2,663 acres $\left(4.2 \mathrm{mi}^{2}\right)$ were unburned. Approximately $22 \%$ and $64 \%$ of the burned area had 
Table 44-Estimated post-fire time of concentration $\left(T_{c}\right)$ and peak flows for 10-year, 24-hour storm $\left(Q_{10}\right)$ using FIRE HYDRO (Cerrelli 2005) for the 2000 Maudlow Fire, Montana (Stuart 2000).

\begin{tabular}{lcc}
\hline Watershed & $\boldsymbol{T}_{\boldsymbol{c}}$ & $\boldsymbol{Q}_{\mathbf{1 0}}$ \\
\hline & (hour) & (cfs) \\
Sulphur Bar & 1.8 & 172 \\
Tributary to Sulphur Bar & 0.8 & 70 \\
Dry Creek & 2.6 & 532 \\
Timber Gulch & 1.0 & 66 \\
\hline
\end{tabular}

high and moderate severity burn. The selected watersheds $\left(0.7\right.$ to $\left.4.0 \mathrm{mi}^{2}\right)$ were modeled for pre- and post-fire peak flow.

Annual precipitation consists mainly of winter snowfall and spring rainfall; however, short-duration, high-intensity summer/fall thunderstorms often produce flash flooding in the area. Thunderstorms during the fire caused flooding within the area on 25 July 2007 and 27 July 2007. To estimate pre- and post-fire peak flow, the 10-year and 25-year, 30-minute storms were used: 0.77 inch and 1.0 inch from NOAA Atlas 14 (Bonnin and others 2006). To estimate pre- and post-fire peak flow, the following assumptions were made:

- The storm was distributed over the entire watershed.

- There is a SCS Type II rainfall distribution (fig. 4).

- The pre-fire CNs were obtained from soil surveys. Otherwise, CNs were based on a vegetation type with (1) hydrologic soil group D (table 13), (2) hydrologic condition between good and fair, and (3) tables in US SCS (1991).

Post-fire CNs were based on pre-fire CNs and burn severities:

- High burn severity $\mathrm{CN}=$ pre-fire $\mathrm{CN}+15$

- Moderate burn severity $\quad \mathrm{CN}=$ pre-fire $\mathrm{CN}+10$

- Low burn severity $\quad \mathrm{CN}=$ pre-fire $\mathrm{CN}+5$

- Maximum $\mathrm{CN}$ value is 100

The time of concentration was based on equation 5 (US SCS 1972; Dunne and Leopold 1978).

Tables 45 and 46 show a dramatic increase in the calculated peak flows in drainages with moderate and high burn severities for the five selected watersheds. Use of the 25-year storm produced a very high peak flow that was beyond the treatable range; therefore, a 10 -year storm was chosen for design storm.

Approximately 0.5 inches of rainfall was received during the fire on 25 July 2007. The storm caused flooding in the Serviceberry Hollow and Water Hollow drainages. Observed flows were estimated as follow:

- Serviceberry Hollow-flow was approximately $25 \mathrm{ft}$ wide by average depth of $2.5 \mathrm{ft}$. Assuming a conservative velocity of $5 \mathrm{ft} \mathrm{s}^{-1}$, the estimated discharged was $313 \mathrm{cfs}$.

- Water Hollow - flow was approximately $11 \mathrm{ft}$ wide by average depth of $3 \mathrm{ft}$. Assuming a conservative velocity of $5 \mathrm{ft} \mathrm{s}^{-1}$, the estimated discharged was 165 cfs.

These estimated values correlated well with the modeling results. 
Table 45-Pre- and post-fire modeling results for the selected watersheds for 10-year, 30-minute storm (0.77 inch) on the 2007 Salt Creek Fire, Utah, using the WILDCAT4 (Hawkins and Greenberg 1990) (Higginson and Jarnecke 2007).

\begin{tabular}{|c|c|c|c|c|c|c|c|}
\hline \multirow[b]{2}{*}{ Watershed } & \multirow[b]{2}{*}{ Area } & \multicolumn{3}{|c|}{ Pre-fire modeling } & \multicolumn{3}{|c|}{ Post-fire modeling } \\
\hline & & $\begin{array}{c}\text { Total } \\
\text { runoff }\end{array}$ & $T_{c}^{a}$ & $\begin{array}{l}\text { Peak } \\
\text { flow }\end{array}$ & $\begin{array}{l}\text { Total } \\
\text { runoff }\end{array}$ & $T_{c}^{a}$ & $\begin{array}{c}\text { Peak } \\
\text { flow }\end{array}$ \\
\hline & $\left(m i^{2}\right)$ & (ac-ft) & (hr) & (cfs) & $(\mathrm{ac}-\mathrm{ft})$ & (hr) & (cfs) \\
\hline Rolley Canyon & 1.2 & 6.0 & 0.76 & 107 & 29.9 & 0.67 & 522 \\
\hline Serviceberry Hollow & 4.0 & 10.4 & 1.01 & 147 & 32.9 & 0.90 & 458 \\
\hline Water Hollow Tributary \#1 & 0.7 & 2.9 & 0.59 & 82 & 9.6 & 0.45 & 270 \\
\hline Water Hollow Tributary \#2 & 1.8 & 6.9 & 0.73 & 153 & 20.7 & 0.67 & 440 \\
\hline Rocky Ridge Creek & 1.2 & 1.3 & 0.64 & 35 & 5.1 & 0.54 & 132 \\
\hline
\end{tabular}

a Time of concentration

Table 46-Pre- and post-fire modeling results for the selected watersheds for 25-year, 30-minute storm (1.0 inch) on the 2007 Salt Creek Fire, Utah, using the WILDCAT4 (Hawkins and Greenberg 1990) (Higginson and Jarnecke 2007).

\begin{tabular}{|c|c|c|c|c|c|c|c|}
\hline \multirow[b]{2}{*}{ Watershed } & \multirow[b]{2}{*}{ Area } & \multicolumn{3}{|c|}{ Pre-fire modeling } & \multicolumn{3}{|c|}{ Post-fire modeling } \\
\hline & & $\begin{array}{c}\text { Total } \\
\text { runoff }\end{array}$ & $T_{c}^{a}$ & $\begin{array}{l}\text { Peak } \\
\text { flow }\end{array}$ & $\begin{array}{c}\text { Total } \\
\text { runoff }\end{array}$ & $T_{c}^{a}$ & $\begin{array}{c}\text { Peak } \\
\text { flow }\end{array}$ \\
\hline & $\left(m i^{2}\right)$ & $(\mathrm{ac}-\mathrm{ft})$ & (hr) & (cfs) & $(\mathrm{ac}-\mathrm{ft})$ & (hr) & (cfs) \\
\hline Rolley Canyon & 1.2 & 11.2 & 0.76 & 201 & 39.7 & 0.67 & 716 \\
\hline Serviceberry Hollow & 4.0 & 20.8 & 1.01 & 290 & 49.2 & 0.90 & 687 \\
\hline Water Hollow Tributary \#1 & 0.7 & 5.0 & 0.54 & 143 & 12.6 & 0.45 & 354 \\
\hline Water Hollow Tributary \#2 & 1.8 & 14.3 & 0.73 & 312 & 31.8 & 0.67 & 680 \\
\hline Rocky Ridge Creek & 1.2 & 3.0 & 0.64 & 81 & 8.1 & 0.54 & 209 \\
\hline
\end{tabular}

Kuyumajian, Greg. [Personal note]. Greg's Curve Number thoughts.

- High burn severity w/water repellent soils $\quad \mathrm{CN}=95$

- High burn severity w/o water repellent soils $\quad \mathrm{CN}=90$ to 91

- Moderate burn severity w/water repellent soils $\quad \mathrm{CN}=90$

- Moderate burn severity w/o water repellent soils $\mathrm{CN}=85$

- Low burn severity $\quad \mathrm{CN}=$ pre-fire $\mathrm{CN}+5$

- Straw mulch with good coverage $\mathrm{CN}=60$

- Seeding w/log erosion barriers 1 year after fire $\quad \mathrm{CN}=75$

- Log erosion barriers w/o water repellent soils $\mathrm{CN}=85$

U.S. Forest Service Coronado National Forest. 2003. Aspen Fire, Coronado National Forest, BAER hydrology report. Tucson, AZ: U.S. Department of Agriculture, Forest Service, Southwestern Region, Coronado National Forest: 24-30.

The WILDCAT4 (Hawkins and Greenberg 1990) was used to estimate peak flow runoff in key watersheds under pre- and post-fire conditions on the 2003 Aspen Fire, Arizona. Limited sampling of water repellency conditions indicated moderate water repellency occurred on severely burned soils. Therefore, all severely burned soils had moderate water repellency (table 47). 
Table 47-Pre- and post-fire Curve Number for the 2003 Aspen Fire, Arizona (U.S. Forest Service Coronado National Forest 2003).

\begin{tabular}{ccccc}
\hline & & \multicolumn{3}{c}{ Post-fire CN } \\
\cline { 3 - 5 } $\begin{array}{c}\text { Hydrologic } \\
\text { Soil Group }\end{array}$ & Pre-fire CN & $\begin{array}{c}\text { High burn } \\
\text { severity }\end{array}$ & $\begin{array}{c}\text { Moderate burn } \\
\text { severity }\end{array}$ & $\begin{array}{c}\text { Low burn } \\
\text { severity }\end{array}$ \\
\hline B & 56 & 65 & - & - \\
C & 67 & 70 to 75 & 80 & 90 \\
D & 77 & 80 to 85 & 90 & 95 \\
\hline
\end{tabular}

Solt, Adam; Muir, Mark. 2006. Warm Fire-hydrology and watershed report. Richfield, UT: U.S. Department of Agriculture, Forest Service, Intermountain Region, Fishlake National Forest. 9 p.

The WILDCAT4 (Hawkins and Greenberg 1990) was used to estimate pre- and post-fire runoff on the 2006 Warm Fire, Utah. The short duration, high intensity monsoonal storms can cause flash flooding and erosional events that were of greatest concern within and downstream of the burned area. The vegetation recovery for the Warm Fire was estimated at 3 years. The 10-year recurrence interval was selected for a design storm, which has a $10 \%$ chance of occurring in any given year and $27 \%$ chance of occurring in the next 3 years and was calculated using equation 7 (Gilman 1964). Also, 30-minute duration was selected to reflect the short duration, high intensity precipitation events that were common in the area.

$$
P=1-\left[1-\left(\frac{1}{T}\right)\right]^{N}
$$

Where:

$P=$ the probability of a rainfall having a given return period $(T)$ occurring at least once in $N$ years

Pre- and post-fire CNs were determined from a combination of sources, including Cerrelli (2005) and Dunne and Leopold (1978). The limestone derived soils of the burned area were determined to be in hydrologic soil group D (low infiltration) and in the ponderosa pine/juniper vegetation type (table D3). The following CNs were selected for the 2006 Warm Fire, Utah:
- Pre-fire
$\mathrm{CN}=80$
- High burn severity
$\mathrm{CN}=90$
- Moderate burn severity
$\mathrm{CN}=85$
- Low burn severity and unburned
$\mathrm{CN}=80$

\section{TR-55}

Lefevre, Robert [and others]. 2002. BAER report, Bullock Fire, Coronado National Forest, Arizona. Tucson, AZ: U.S. Department of Agriculture, Forest Service, Southwestern Region, Coronado National Forest. 14 p.

The TR-55 model was used to estimate post-fire peak flows. Table 20 shows the analysis that was conducted. The "2-year post-fire equivalent" displays the 
corresponding flood level expected from a typical 2-year storm event. In other words, there is a $50 \%$ chance of a storm event that might happen in any given year.

WEPP model

Sirucek, Dean; Olson, Dennis; Butterfly, Henry; Johnson, Steve. 2006. Interagency burned area emergency stabilization \& rehabilitation plan, Red Eagle Fire, watershed resource assessment, hydrology and soils. 24 p.

The WEPP model was used to estimate 20 years of pre- and post-fire runoff and erosion potential. The results showed more runoff events with greater risks of flood and erosion (table 21). The WEPP model predicted dramatic increases of rainfall and snowmelt runoff events from 2 and 0 for pre-fire conditions to 79 and 14 for post-fire conditions.

\section{R1/R4 sediment model}

Story, Mark; Johnson, Steve; Stuart, Bo; Hickenbottom, Jennifer; Thatcher, Ron; Swartz, Scott. 2006. BAER specialist report, hydrology and roads, Derby Fire. 17 p.

Potential sediment increase from the 2006 Derby Fire, Montana, was modeled using the R1/R4 sediment model (Cline and others 1981). The sediment coefficient was adjusted based on existing road, timber harvest, and burn unit conditions. The R1/R4 model estimated the sediment increase much less than the WEPP model, because the R1/R4 model used sediment delivery and routing coefficients to estimate sediment levels at accounting points at or near the Gallatin NF.

\section{Culvert sizing}

Cahoon, Joel. (2005, August 11-last update). Circular culvert design spreadsheet [Online]. Available: http://www.wti.montana.edu/ Documents/Reports/PDF/CMP_Hydraulics.xls [2008, July 8].

A quick and useful Excel template was developed for culvert sizing. The spreadsheet can be downloaded from the website. The spreadsheet displays a culvert rating curve based on inlet, outlet, and head variable, and automatically adjusts flow type to entrance and exit conditions. The spreadsheet can generate rating tables and display them by adjusting the variables, including culvert diameter, length, and slope. The following comments should be noted:

1. The spreadsheet was developed for corrugated metal pipe culverts.

2. Prior to opening the file in Excel, go to the Tools/Add-Ins menu and select (1) Analysis ToolPak, (2) Analysis ToolPak-VBA, and (3) Solver Add-in then update Add-Ins link. Quit Excel, re-load Excel, enable macros, and open the file.

3. The spreadsheet numbers that the user adjusts are displayed in blue.

4. Simply change the blue numbers, and select "Run" to generate a new rating curve. 


\section{Rolling dip/water bar}

Furniss, Michael J. (2002-last update). The six-D system for effective waterbars [Online]. Available: http://www.fs.fed.us/r5/baer/six-d.html [2008, July 13].

Waterbars control erosion on roads, skid trails, trails, and firelines. Waterbars should break up larger drainage areas into smaller drainages that can handle runoff during heavy rainfall resulting in little or no erosion. Waterbars should also break up runoff so it reduces the energy available to erode the road surface. There are six D's to make effective waterbars.

1. Drainage area. When deciding where to put waterbars, estimate the drainage area. If the road or trail width is 12 feet or less, table 48 can be used. If the road or trail is wider than 12 feet, or runoff is contributed from cutslope (e.g., seepage or leaking), then adjustments should be made as discussed in 2 .

2. Distance. Distance is the spacing between waterbars on a road or trail. If there is runoff contribution from a cutslope or small stream crossing, place a waterbar at that location so that water can keep flowing downhill without disturbing that road or trail surface much. If the road or trail is wider than 12 feet, modify the distance in table 48 by the proportion of that wider road width to 12 feet. For example, if a road is 15 feet wide, the drainage area is one quarter greater. Therefore, the distance should be one quarter less than indicated in table 48.

3. Diagonal. Do not oppose the flow energy. Waterbars built diagonal to the road lead the water away and are more efficient. Also, a diagonal waterbar has a gentle slope along its base; therefore, it is smoother and easier to drive over. A simple rule is to add " 5 " to the road gradient and build the waterbar that number of degrees off the road centerline.

4. Divert. A good waterbar should convey the water off the road or trail. It should be deep enough to handle the flow, and at the same time, durable to last as long as needed. Excavation is much more effective than fill-in for creating durable and effective waterbars.

5. Discharge. A good waterbar should discharge the flow. If it blocks the flow, or is a dam, the waterbar will likely fail. It should have an open outlet.

6. Dissipate. A good waterbar should dissipate the flow below the outlet to exhaust its erosive energy and let the water infiltrate into the soil. Slash, rock, or debris are often placed below the outlet. Enough buffer distance is also considered.

Table 48-Recommended maximum spacing for waterbars on temporary roads, trails, skid trails, and fire lines (Furniss 2002).

\begin{tabular}{|c|c|c|c|c|}
\hline \multirow[b]{2}{*}{ Gradient } & \multicolumn{4}{|c|}{ Erosion hazard rating for area } \\
\hline & $\begin{array}{c}4 \text { to } 5 \\
\text { Low }\end{array}$ & $\begin{array}{c}6 \text { to } 8 \\
\text { Medium }\end{array}$ & $\begin{array}{c}9 \text { to } 10 \\
\text { High }\end{array}$ & $\begin{array}{c}11 \text { to } 13 \\
\text { Very high }\end{array}$ \\
\hline$(\%)$ & \multicolumn{4}{|c|}{ 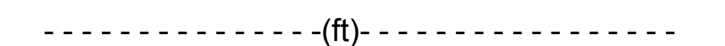 } \\
\hline 1 to 6 & 400 & 350 & 300 & 250 \\
\hline 7 to 9 & 300 & 250 & 200 & 150 \\
\hline 10 to 14 & 200 & 175 & 150 & 125 \\
\hline 15 to 20 & 150 & 120 & 90 & 60 \\
\hline
\end{tabular}




\section{Culvert survey for treatment assessment}

Sirucek, Dean; Olson, Dennis; Butterfly, Henry; Johnson, Steve. 2006.

Interagency burned area emergency stabilization \& rehabilitation plan,

Red Eagle Fire, watershed resource assessment, hydrology and soils. 24 p.

A field review of stream crossing/culverts was conducted on the roads within the 2006 Red Eagle Fire, Montana. The existing conditions were described for each culvert installation to assess the potential impact of post-fire peak flow to each site. Table 49 shows culvert survey information and road treatment recommendations.

Table 49-Summary information for culverts affected by the 2006 Red Eagle Fire, Montana (Sirucek and others 2006).

\begin{tabular}{|c|c|c|c|c|c|c|}
\hline Stream & Road name & $\begin{array}{l}\text { Culvert } \\
\text { size }\end{array}$ & $\begin{array}{c}\text { Height of } \\
\text { culvert } \\
\text { rust-line }\end{array}$ & $\begin{array}{c}\text { Stream } \\
\text { bank-full } \\
\text { width }\end{array}$ & $\begin{array}{c}\text { Basin burned } \\
\text { above } \\
\text { culvert }^{\mathrm{a}}\end{array}$ & Recommendation \\
\hline & & $-\ldots$ & - - - - -inches or ft- - - & 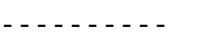 & & \\
\hline Fox Creek & Truck trail road & $18 ”$ & 9" depth & $18 "$ to $24 "$ & $\mathrm{H}$ & Clean out \\
\hline Livermore & A road & $18 "$ & $10 "$ to $11 "$ & $36 "$ to $38 "$ & $\mathrm{H}$ & $\begin{array}{l}\text { Replace w/24" } \\
\text { squash }^{\mathrm{b}} \mathrm{CMP}^{\mathrm{C}}\end{array}$ \\
\hline Livermore & A road & $\begin{array}{l}\text { Native wood } \\
\text { (collapsed) }\end{array}$ & NA & $24 "$ to $28 "$ & $\mathrm{H}$ & $\begin{array}{l}\text { Replace w/36" } \\
\text { squash CMPc }\end{array}$ \\
\hline Livermore & A road & $24 "$ & $13^{\prime \prime}$ & $24 "$ to $28 "$ & $\mathrm{H}$ & $\begin{array}{l}\text { Replace } w / 36^{\prime \prime} \\
\text { squash } \mathrm{CMP}^{\mathrm{C}}\end{array}$ \\
\hline Livermore & A road & $30 "$ & $5 "$ & $40 "$ to $48 "$ & $\mathrm{H}$ & Clean out \\
\hline Livermore & A road & $36 "$ & $20 "$ & $44 "$ to $48 "$ & $L$ & Clean out \\
\hline Livermore & A road & $24 "$ & $7 "$ & $44 "$ to $48 "$ & $L$ & Clean out \\
\hline South Fork Milk & Milk road spur & $\begin{array}{l}26 " \text { by } 40 " \\
\text { (squashed) }\end{array}$ & $\begin{array}{l}\text { New, no rustline, } \\
12 \text { " flow depth } \\
\text { at examination }\end{array}$ & $55^{\prime \prime}$ to $65^{\prime \prime}$ & $\mathrm{H}$ & Clean out \\
\hline South Fork Milk & Milk road spur & $24 "$ & $14 "$ & $36 "$ to $40 "$ & $\mathrm{H}$ & $\begin{array}{l}\text { Replace w/36" } \\
\text { squash CMPC }\end{array}$ \\
\hline Fox Creek & A road & $36 "$ & $\begin{array}{l}\text { 24" newly constructed } \\
\text { beaver exposure }\end{array}$ & $10 \mathrm{ft}$ & $\mathrm{H}$ & $\begin{array}{l}\text { Replace w/48" } \\
\text { squash CMPC }\end{array}$ \\
\hline Fox Creek & A road & $18^{\prime \prime}$ & $6 "$ & $24 "$ & $\mathrm{H}$ & Clean out \\
\hline Fox Creek & A road & $18 "$ & $\begin{array}{l}\text { Nearly filled } \\
\text { w/sediment }\end{array}$ & $48 "$ & $\mathrm{H}$ & Clean out \\
\hline Fox Creek & D road & $36 "$ & $\begin{array}{l}\text { 18" nearly blocked } \\
\text { by old beaver fill, } \\
\text { and compressed }\end{array}$ & $6 \mathrm{ft}$ & $\mathrm{H}$ & $\begin{array}{l}\text { Replace w/48" } \\
\text { squash CMPC }\end{array}$ \\
\hline Fox Creek & B road & $18 "$ & $2 "$ & Draw & $\mathrm{H}$ & Upsize \\
\hline Fox Creek & B road & $18 "$ & $2 "$ & Draw & $\mathrm{H}$ & Clean out \\
\hline Fox Creek & B road & $36 "$ & $10 "$ & $\begin{array}{l}10 \mathrm{ft} \text { w/beaver } \\
\text { complex }\end{array}$ & $\mathrm{H}$ & $\begin{array}{l}\text { Upsize culvert } \\
\text { (72" squash) }\end{array}$ \\
\hline Fox Creek & B road & $18 "$ & Unknown & Draw & L & Clean out \\
\hline
\end{tabular}


Stuart, Bo. 2000. Maudlow Fire, Burned Area Emergency Rehabilitation (BAER) plan. Townsend, MT: U.S. Department of Agriculture, Forest Service, Northern Region, Helena National Forest.

A culvert survey was completed for the burned areas of Dry Creek and three affected tributaries to Deep Creek, Sulphur Bar Creek, Blacktail Creek, and Cedar Bar Creek. The purpose of this survey was to qualitatively assess erosion hazard and culvert plugging that might compound the degradation of the aquatic resources from damaging heavy storm/runoff events. Table 50 shows the culvert survey to assess road and drainage hazard for the Maudlow Fire, Montana, in 2000 .

\section{Evaluation of road treatment implementation}

Johnson, Ada Suzanne. 2003. Aspen Fire 2003 treatment success monitoring report. Tucson, AZ: U.S. Department of Agriculture, Forest Service, Southwest Region, Coronado National Forest. 21 p.

The Aspen Fire burned 84,750 acres in the Coronado National Forest, Arizona, in June and July, 2003. Emergency road treatments were applied to 6 miles of road, and road treatments were evaluated during and upon completion by visual observation (table 51). The road treatments were successful in protecting roads and maintaining access to residences and critical communication sites, and continue to perform as expected, with the single exception of Turkey Run Road where a culvert was removed and a rolling dip was constructed.

The rolling dip failed under base-flow conditions. The natural gradient of stream bed drops 2.5 to $3 \mathrm{ft}(0.8$ to $0.9 \mathrm{~m})$ over the width of the road crossing. The downstream side of the dip eroded and the road was very close to impassible for long wheel-base vehicles. The drainage showed little or no evidence of increased flows since the fire. Also, a culvert at the mouth of the canyon was damaged. Runoff from heavy rains pushed boulders and debris across the roadway and significantly damaged the shoulder and integrity of the roadway downstream. Boulders and debris should be considered when assessing road treatments.

Frazier, Jim; [and others]. 2005. BAER report, Cedar Fire, Cleveland National Forest, California. San Diego, CA: U.S. Department of Agriculture, Forest Service, Pacific Southwest Region, Cleveland National Forest. 12 p.

Road treatments were implemented after the 2003 Cedar Fire, California, including restoring drainage function, installing drainage features and gates, conducting storm patrols, and posting warning signs. Significant rainfall events occurred the week of October 18, 2004, and the following January and February, resulting in the $3^{\text {rd }}$ wettest seasons on record. A road survey was conducted in February and March of 2005 to assess road conditions and review the effectiveness of treatments installed in spring 2004. Loss of upslope vegetation and large precipitation events produced larger than expected runoff, resulting in culvert capacities being exceeded, erosion occurring at structures, and headcuts and culverts being severely undercut. Table 52 shows a summary of road treatments initially implemented and those implemented after the 2005 wet winter season. 
Table 50-Culvert survey results to assess road and drainage hazard for the 2000 Maudlow Fire, Montana (Stuart 2000).

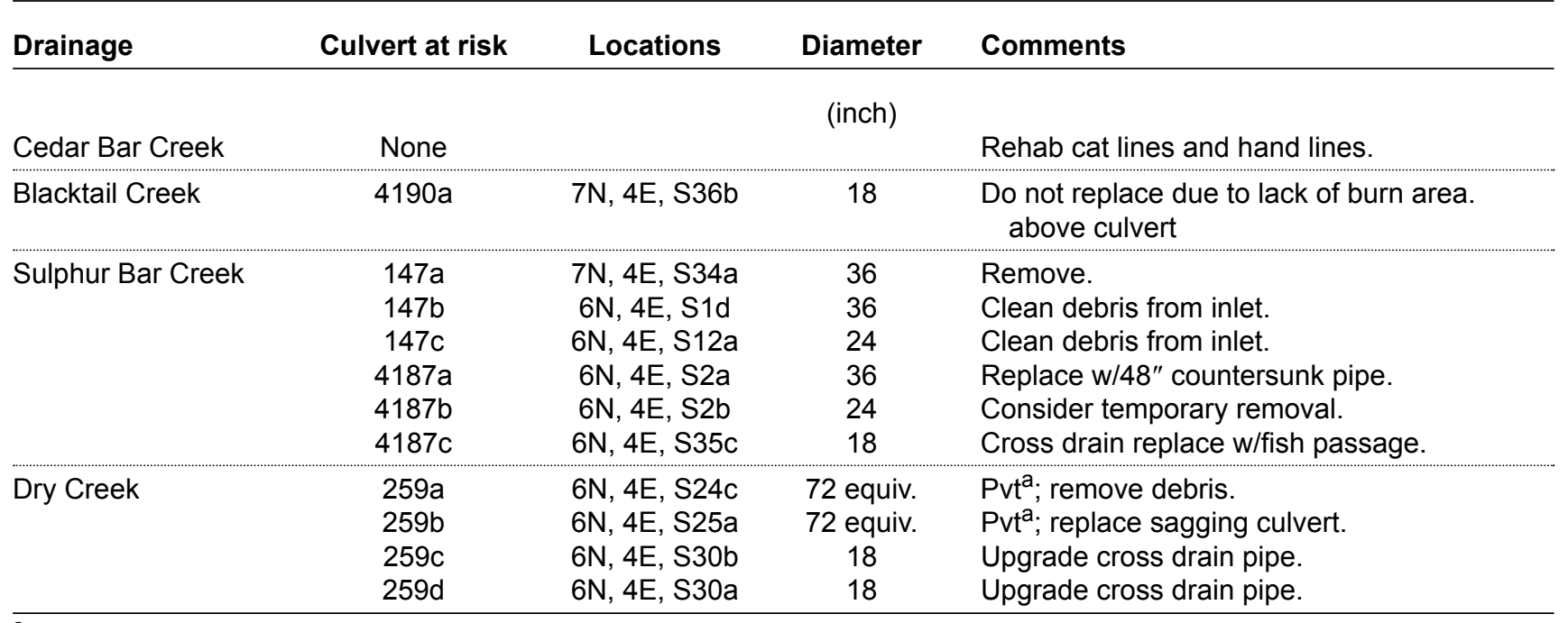

a Pavement

Table 51-Evaluation of road treatment implementation for the 2003 Aspen Fire, Arizona (Johnson 2003).

\begin{tabular}{|c|c|c|c|}
\hline Road name & Treatment & $\begin{array}{l}\text { Evaluation } \\
\text { relative to goals }\end{array}$ & Evaluation method \\
\hline Fern Ridge Road & Remove culverts & $\begin{array}{l}\text { Culverts removed, } \\
\text { road passable }\end{array}$ & Visual observation by forest engineer \\
\hline Sykes Knob Road & Remove culverts & $\begin{array}{l}\text { Culverts removed, } \\
\text { road passable }\end{array}$ & Visual observation by forest engineer \\
\hline Turkey Run Road & Remove culvert & $\begin{array}{l}\text { Culvert removed, } \\
\text { road passable }\end{array}$ & Visual observation by forest engineer \\
\hline Marshall Gulch Road & $\begin{array}{l}\text { Place trash rack at } \\
\text { inlet to deflect } \\
\text { material over road }\end{array}$ & $\begin{array}{l}\text { Goal accomplished, } \\
\text { trash rack placed }\end{array}$ & Trash rack observed in place \\
\hline Summerhaven main road & $\begin{array}{l}\text { Place trash racks at } \\
\text { two culvert inlets to } \\
\text { deflect material } \\
\text { over road }\end{array}$ & Trash rack placed & Visual observation by hydrologists \\
\hline Mt Lemmon Lookout & Remove culverts & $\begin{array}{l}\text { Culverts removed, } \\
\text { road passable }\end{array}$ & Visual observation by forest engineer \\
\hline Road into Willow Creek & $\begin{array}{l}\text { Armor and buttress } \\
\text { three crossings }\end{array}$ & $\begin{array}{l}\text { Culvert removed, } \\
\text { road passable }\end{array}$ & Visual observation by forest engineer \\
\hline Sabino Canyon Rec. Road & $\begin{array}{l}\text { Install concrete } \\
\text { aprons on bridge } \\
\text { approaches }\end{array}$ & Apron installed & Visual observation by forest engineer \\
\hline
\end{tabular}


Table 52_Summary of road treatments initially implemented and after the 2005 wet winter season for the 2003 Cedar Fire, California (Frazier and others 2005).

\begin{tabular}{|c|c|}
\hline $\begin{array}{l}\text { Road } \\
\text { number }\end{array}$ & Road name \\
\hline 13509 & Dye Canyon \\
\hline $13 S 10$ & Westside \\
\hline $13 S 11$ & Cedar Creek \\
\hline $14 S 03$ & Garnet Peak \\
\hline $14 S 04$ & Deer Park \\
\hline $14 S 05$ & Pine Creek \\
\hline $14 S 07$ & Tule Springs \\
\hline $14 S 08$ & Conejos Valley \\
\hline $14 S 08$ & Dubois \\
\hline
\end{tabular}

$15 S 21 \quad$ Miners

15 S24 Goude

$15 S 30 \quad$ Anderson Truck Trail

\section{Recommended treatments}

\begin{tabular}{ll}
\hline \multicolumn{1}{c}{ Initially implemented } & \multicolumn{1}{c}{ After the $\mathbf{2 0 0 5}$ wet season } \\
$\begin{array}{l}\text { Further assessment needed } \\
\begin{array}{l}\text { Restore drainage function, construct/ } \\
\text { reconstruct dips and overside drains, } \\
\text { riprap fill slopes, storm patrol, and BAER }\end{array}\end{array}$ & $\begin{array}{l}\text { Restore drainage function, reconstruct dips, } \\
\text { repair/replace damaged overside drains, } \\
\text { warning signs. }\end{array}$ \\
$\begin{array}{l}\text { re-install riprap (9.5 mi). } \\
\text { Restore drainage function, construct/ } \\
\text { reconstruct dips and overside drains, } \\
\text { riprap fill slopes, storm patrol, and BAER }\end{array}$ & $\begin{array}{l}\text { Restore drainage function, reconstruct dips, } \\
\text { repair/replace damaged overside drains, } \\
\text { re-install riprap (3.8 mi). }\end{array}$
\end{tabular}
warning signs.

No treatments recommended

Restore drainage function and storm patrol.

Restore drainage function, reconstruct dips, repair/replace damaged overside drains, re-install riprap (3.3 mi).

Restore drainage function and place riprap for fillslope protection.

Restore drainage function, repair/replace damaged overside drains, re-install riprap (7.0 mi).

Restore drainage function, reconstruct dips, repair/replace damaged overside drains, re-install riprap (4.0 mi).

Restore drainage function, reconstruct dips, repair/replace overside drains, re-install riprap (1.2 mi w/approx $50 \%$ on Capitan Grande Indian Reservation).

Restore drainage function and storm patrol.

Restore drainage function, construct dips and overside drains, place riprap at the end of existing overside drain flumes, storm patrol, and BAER warning signs.

Restore drainage function, reconstruct dips, repair/replace damaged overside drains, re-install riprap, replace two $30^{\prime \prime} \times 60^{\prime \prime} \mathrm{CMP}^{a}$ culverts, replace lost aggregate surfacing (1.6 mi plus $0.9 \mathrm{mi}$ on private lands).

\footnotetext{
${ }^{\text {a } C o r r u g a t e d ~ M e t a l ~ P i p e ~}$
} 


\section{Summary of Gray Literature on BAER Road Treatments}

From the various gray literature discussed, we summarized the following information for BAER road treatments:

- USGS regression and NRCS Curve Number methods were mostly used to estimate post-fire peak flow. However, these methods are not well established for post-fire conditions. Many BAER team members used their own rules to use USGS regression and NRCS CN methods; therefore, there is no consistent way to estimate post-fire peak flow.

- Design tools, as well as information on culverts and rolling dips/water bars, were available. Little information was found for the other road treatments.

- Many BAER road treatments for individual stream crossings were prescribed based on road/culvert survey, without considering capacities of existing road structure and increased post-fire peak flow. A road/culvert survey can give the current road/culvert conditions after the fire to help managers prescribe road treatments. However, a road/culvert survey alone might not provide enough information to prescribe road treatments for individual stream crossings.

- Most monitoring efforts were made on hillslope treatments, and little information was available to evaluate road treatment effectiveness. The most commonly used monitoring method was visual observation. 


\section{Conclusions}

Our analysis of Burned Area Reports, the literature, interview comments, and gray literature lead us to the following conclusions:

- Post-fire road conditions should be evaluated and road treatments implemented only if the values at risk warrant the treatment.

- Road treatment implementation should be based on regional characteristics, including the timing of the first damaging storm and window of implementation.

- Post-fire peak flow estimation is important for selecting appropriate road treatments. USGS regression and NRCS Curve Number methods are mostly used.

- USGS regression and NRCS Curve Number methods are not well established for post-fire conditions. Several BAER team members use simple rules of their own.

- Rolling dip/water bar, culvert upgrading, and ditch cleaning/armoring are the most frequently used road treatments.

- Rolling dip/water bar and ditch cleaning/armoring are preferred by all Regions. For Regions 1 and 4, culvert upgrading is preferred, especially for fish-bearing streams. For Region 3, culvert removal with road closure and warning signs are preferred.

- Little information is available on estimating flood and debris flow capacities of road treatments other than culverts and rolling dip/water bar.

- No data is available on estimating and evaluating other road treatment capacities (e.g., rolling dips and water bars).

- Many BAER road treatments were recommended for individual stream crossings based on road/culvert surveys, without considering the capacities of existing road structures and increased post-fire peak flows.

- Relatively little monitoring of BAER road treatments has been conducted. Treatment effectiveness has focused mainly on hillslope treatments such as seeding, contour-felled logs, and mulch, with little information available on road treatments. 


\section{Recommendations}

Based on the findings of this study, we recommend the following to further expand our knowledge and understanding of road treatment effects in the postfire environment:

- Post-fire peak flow estimation methods vary. Further research is needed to ensure that the BAER specialists can easily compare pre- to post-fire peak flow changes.

- There exists insufficient knowledge of the capacity of BAER road treatments to pass estimated flood and debris flows. Design tools should be developed to estimate flood and debris flow capacity of BAER road treatments (e.g., ford crossings, and ditch cleaning) so that the BAER specialists can select road treatments based on post-fire peak flow changes and the road treatment capacities.

- Insufficient data is available to evaluate road treatment effectiveness. More systematic monitoring and further research are recommended to evaluate road treatment effectiveness. 


\section{References}

Arkell, Richard E.; Richards, Frank. 1986. Short duration rainfall relations for the western United States. Conference on climate and water management - a critical era and conference on the human consequences of 1985's climate; 1986 August 4-7; Asheville, NC. Boston, MA: American Metrological Society: 136-141.

Berenbrock, Charles. 2002. Estimating the magnitude of peak flows at selected recurrence intervals for streams in Idaho. Water-Resources Investigations Report 02-4170. Denver, CO: U.S. Geological Survey. 59 p.

Bigio, Erica R.; Cannon, Susan H. 2001. Compilation of post-wildfire runoff data from the western United States. Open-File Report 2001-474. Denver, CO: U.S. Geological Survey. 24 p.

Boiten, Wubbo. 2002. Flow measurement structures. Flow Measurement and Instrumentation. 13(5-6): 203-207.

Bonnin, Geoffrey M.; Martin, Deborah; Lin, Bingzhang; Parzybok, Tye; Yekta, Michael; Riley, David. 2006. NOAA Atlas 14. Precipitation-frequency atlas of the United States. Volume I version 4.0: semiarid southwest (Arizona, Southeast California, Nevada, New Mexico, Utah). Silver Spring, MD: NOAA.

Calkin, Dave E.; Hyde, Kevin D.; Robichaud, Peter R.; Jones, J. Greg; Ashmun, Louise E.; Loeffler, Dan. 2007. Assessing post-fire values-at-risk with a new calculation tool. Gen. Tech. Rep. RMRS-GTR-205. Fort Collins, CO: U.S. Department of Agriculture, Forest Service, Rocky Mountain Research Station. 32 p.

Cerrelli, G. A. 2005. FIRE HYDRO, a simplified method for predicting peak discharges to assist in the design of flood protection measures for western wildfires. In: Moglen, Glenn E., eds. Proceedings: 2005 watershed management conferencemanaging watersheds for human and natural impacts: engineering, ecological, and economic challenges; 2005 July 19-22; Williamsburg, VA. Alexandria, VA: American Society of Civil Engineers: 935-941.

Chin, David A. 2000. Surface-water hydrology. In: Chin, David A. Water-resources engineering. Upper Saddle River, NJ: Prentice Hall: chapter 6.

Cline, R.; Cole, G.; Megahan, W.; Patten, R.; Potyondy, J. 1981. Guide for predicting sediment yields from forested watersheds (the R1/R4 sediment guidelines). Missoula, MT: U.S. Department of Agriculture, Forest Service, Northern and Intermountain Regions.

Cocke, Allison E.; Fulé, Peter Z.; Crouse, Joseph E. 2005. Comparison of burn severity assessments using Differenced Normalized Burn Ratio and ground data. International Journal of Wildland Fire. 14(2): 189-198.

Cooper, Richard M. 2005. Estimation of peak discharges for rural, unregulated streams in western Oregon. Scientific Investigations Report 2005-5116. Reston, VA: U.S. Geological Survey. 134 p.

Daly, Christoper. 2007 (October 24 - last update). PRISM Group [Homepage of Prism Group], [Online]. Available: http://www.prism.oregonstate.edu/ [2007, November 6].

DeBano, L. F.; Neary, D. G.; Ffolliott, P. F. 1998. Fire's effects on ecosystems. New York, NY: John Wiley \& Sons. 333 p.

Dunne, Thomas; Leopold, Luna B. 1978. Water in environmental planning. New York, NY: W. H. Freeman and Company. 818 p.

Elliot, William J. 2007 (January 22—last update). Forest Service WEPP Interfaces [Homepage of Forest Service WEPP Interfaces], [Online]. Available: http://forest. moscowfsl.wsu.edu/fswepp/ [2008, January 3]. 
Farmer, E. E.; Fletcher, J. E. 1972. Rainfall intensity-duration-frequency relations for the Wasatch Mountains of northern Utah. Water Resources Research. 8(1): 266-271.

Farnsworth, R. K.; Thompson, E. S.; Peck, E. L. 1982. Evaporation altas for the contiguous 48 United States. NOAA Technical Report NWS 33. Silver Spring, MD: National Oceanic and Atmospheric Administration. 26 p.

Fenneman, N. M. 1946. Physical divisions of the United States: U.S. Geological Survey map prepared in cooperation with the Physiographic Committee of the Geological Survey, scale 1:7,000,000 (reprinted 1964). Reston, VA: U.S. Geological Survey.

Flanagan, D. C.; Livingston, S. J., eds. 1995. WEPP user summary. NSERL Report No.11. West Lafayette, IN: U.S. Department of Agriculture, Agricultural Research Service, National Soil Erosion Research Laboratory. 131 p.

Flint, R. F. 1955. Pleistocene geology of eastern South Dakota. Professional Paper 262. Reston, VA: U.S. Geological Survey. 173 p.

Foltz, Meg. 2008. A WATBAL watershed program input data and summary report for U.S. Department of Agriculture, Forest Service, Clearwater National Forest. Unpublished data supplied to author by M. Foltz, a Clearwater National Forest hydrologist.

Gallaher, B. M.; Koch, R. J. 2004. Cerro Grande Fire impacts to water quality and stream flow near Los Alamos National Laboratory: Results of four years of monitoring. LA-14177. Springfield, VA: U.S. Department of Commerce, National Technical Information Service. $195 \mathrm{p}$.

Gilman, Charles S. 1964. Rainfall. In: Chow, Ven Te. Handbook of applied hydrology. New York, NY: McGraw-Hill: section 9.

Grove, Matt; Harbor, Jon; Engel, Bernard. 1998. Composite vs. distributed curve numbers: effects on estimates of storm runoff depths. Journal of the American Water Resources Association. 34(5): 1015-1023.

Harris, D. D.; Hubbard, Larry L.; Hubbard, Lawrence E. 1979. Magnitude and frequency of floods in western Oregon. Open-File Report 79-553. Portland, OR: U.S. Geological Survey. 35 p.

Harris, D. D.; Hubbard, Lawrence E. 1983. Magnitude and frequency of floods in eastern Oregon. Water-Resources Investigations Report 82-4078. Denver, CO: U.S. Geological Survey. 39 p.

Haupt, H. F. [and others]. 1976. Forest hydrology, part II, hydrologic effects of vegetation manipulation. Missoula, MT: U.S. Department of Agriculture, Forest Service, Northern Region.

Hawkins, R. H.; Greenberg, R. J. 1990. WILDCAT4 Flow Model. [This edition further enhances Moore's version] School of Renewable Natural Resources, University of Arizona, Tucson, AZ. BLM contact: Dan Muller, Denver, CO.

Hawkins, R. H. 2008. Personal communication with the model developer of WILDCAT4 at U.S. Department of Agriculture, Forest Service, Rocky Mountain Research Station, Moscow Forest Science Laboratory.

Higginson, Brad; Jarnecke, Jeremy. 2007. Salt Creek BAER-2007 Burned Area Emergency Response. Provo, UT: Unita National Forest; Hydrology Specialist Report. $11 \mathrm{p}$.

Istanbulluoglu, Erkan; Tarboton, David G.; Pack, Robert T.; Luce, Charles. 2003. A sediment transport model for incision of gullies on steep topography. Water Resources Research. 39(4): 1103.

Istanbulluoglu, Erkan; Tarboton, David G.; Pack, Robert T.; Luce, Charles. 2002. A probablistic approach for channel initiation. Water Resources Research. 38(12): 1325. 
Istanbulluoglu, Erkan; Tarboton, David G.; Pack, Robert T.; Luce, Charles. 2004. Modeling of the interactions between forest vegetation, disturbances, and sediment yields. Journal of Geophysical Research. 109: F01009.

Jennings, Marshall E.; Thomas, Wilbert O., Jr.; Riggs, H. C. 1994. Nationwide summary of U.S. Geological Survey regional regression equations for estimating magnitude and frequency of floods for ungaged sites, 1993. Water-Resources Investigations Report 94-4002. Denver, CO: U.S. Geological Survey. 196 p.

Johnson, Ada Suzanne. 2003. Aspen fire 2003 treatment success monitoring report. Tucson, AZ: U.S. Department of Agriculture, Forest Service, Southwest Region, Coronado National Forest. $21 \mathrm{p}$

Johnson, Steve; Gould, Jessica. 2003. Burned area emergency stabilization and rehab plan, Blackfoot Complex Fires, Flathead NF, watershed resource assessment. Libby, MT: U.S. Department of Agriculture, Forest Service, Northern Region, Kootenai National Forest. $10 \mathrm{p}$.

Jones, Richard. 2000. BAER report, Crooked Fire, Clearwater National Forest, Idaho. Orofino, ID: U.S. Department of Agriculture, Forest Service, Northern Region, Clearwater National Forest. $15 \mathrm{p}$.

Jones, Richard. 2005. Watershed response model for forest management: WATBAL technical users guide, revised. Orofino, ID: U.S. Department of Agriculture, Forest Service, Northern Region, Clearwater National Forest. 36 p.

Kenney, Terry A.; Wilkowske, Chris D.; Wright, Shane J. 2007. Methods for estimating magnitude and frequency of peak flows for natural streams in Utah. Scientific Investigations Report 2007-5158. Reston, VA: U.S. Geological Survey. $28 \mathrm{p}$.

Key, Carl H.; Benson, Nathan C. 2006. Landscape assessment: Sampling and analysis methods. In: Lutes, Duncan C., eds. FIREMON: Fire Effects Monitoring and Inventory System. Gen. Tech. Rep. RMRS-GTR-164-CD. Fort Collins, CO: U.S. Department of Agriculture, Forest Service, Rocky Mountain Research Station. $1 \mathrm{CD}$.

Kjelstorm, L. C.; Moffat, R. L. 1981. A method for estimating flood-frequency parameters for streams in Idaho. Open-File Report 81-909. Boise, ID: U.S. Geological Survey. 101 p.

Knowles, Scott M.; Sumioka, Steve S. 2001. The national flood-frequency programmethods for estimating flood magnitude and frequency in Washington, 2001. USGS Fact Sheet 016-01. Reston, VA: U.S. Geological Survey. 4 p.

Kuyumjian, Gregory A. 2007. Personal communication with a Santa Fe National Forest hydrologist at U.S. Department of Agriculture, Forest Service, Santa Fe National Forest.

Leaf, C. F.; Brink, G. E. 1973. Hydrologic simulation model of the Colorado subalpine forest. Research Paper RM-107. Fort Collins, CO: U.S. Department of Agriculture, Forest Service, Rocky Mountain Forest and Range Experiment Station. 22 p.

Lefevre, Robert [and others]. 2002. BAER report, Bullock Fire, Coronado National Forest, Arizona. Tucson, AZ: U.S. Department of Agriculture, Forest Service, Southwestern Region, Coronado National Forest. 14 p.

Livingston, Russell K.; Earles, T. Andrew; Wright, Kenneth R. 2005. Los Alamos post-fire watershed recovery: a curve-number-based evaluation. In: Moglen, Glenn E., eds. Proceedings: 2005 watershed management conference-managing watersheds for human and natural impacts: engineering, ecological, and economic challenges; 2005 July 19-22; Williamsburg, VA. Alexandria, VA: American Society of Civil Engineers: 471-481.

Luce, Charles H.; Tarboton, David G.; Istanbulluoglu, Erkan; Pack, Robert T. 2005. Reply to comment by Johnathan J. Rhodes on "Modeling of the interactions between forest vegetation, disturbances, and sediment yields." Journal of Geophysical Research. 110: F01013. 
Luce, Charles. 2005. Land use and land cover effects on runoff processes: fire. Encyclopedia of Hydrological Sciences. 13: 1831-1837.

Mann, Michael P.; Rizzardo, Julé; Satkowski, Richard. 2004. Evaluation of methods used for estimating selected streamflow statistics, and flood frequency and magnitude, for small basins in north coastal California. Scientific Investigations Report 2004-5068. Reston, VA: U.S. Geological Survey. 92 p.

Mason, Robert R., Jr.; Fuste, Luis A.; King, Jeffrey N.; Thomas, Wilbert O., Jr. 2000. The national flood-frequency program - methods for estimating flood magnitude and frequency in rural areas in New Mexico. USGS Fact Sheet 050-00. Reston, VA: U.S. Geological Survey. 4 p.

Miller, J. F.; Frederick, R. H.; Tracey, R. J. 1973a. NOAA Atlas 2. Precipitationfrequency atlas of the western United States. Volume I-Montana. Silver Spring, MD: NOAA.

Miller, J. F.; Frederick, R. H.; Tracey, R. J. 1973b. NOAA Atlas 2. Precipitationfrequency atlas of the western United States. Volume V-Idaho. Silver Spring, MD: NOAA.

Miller, Kirk A. 2003. Peak-flow characteristics of Wyoming streams. Water-Resources Investigations Report 03-4107. Denver, CO: U.S. Geological Survey. 79 p.

Montana Department of Commerce. (2003 - last update). Montana Fire Facts, Fires of 2000 [Homepage of Montana Fires of 2000], [Online]. Available: http://visitmt. com/fire/2000fires/fires2k.htm [2008, July 11].

Moody, John A.; Martin, Deborah A. 2001. Hydrologic and sedimentologic response of two burned watersheds in Colorado. Water-Resources Investigations Report 014122. Denver, CO: U.S. Geological Survey. 142 p.

Moody, John A.; Martin, Deborah A.; Haire, Sandra L.; Kinner, David A. 2007. Linking runoff response to burn severity after a wildfire. Hydrological Processes. 22(13): 2063-2074. DOI: 10.1002/hyp.6806.

Napper, Carolyn. 2006. Burned Area Emergency Response treatment catalog. Watershed, Soil, Air Management 0625 1801-SDTDC. San Dimas, CA: U.S. Department of Agriculture, Forest Service, San Dimas Technology \& Development Center. $254 \mathrm{p}$.

National Oceanic and Atmospheric Administration. 2008 (March 19-last update). NOAA's National Weather Service Hydrometeorological Design Studies Center [Hompage of HDSC], [Online]. Available: http://www.nws.noaa.gov/oh/hdsc/index. html [2008, May 6].

Neary, Daniel G.; Ffolliott, Peter F.; Landsberg, Johanna D. 2005. Fire and streamflow regimes. In: Neary, Daniel G.; Ryan, Kevin C.; DeBano, Leonard F., eds. Wildland fire in ecosystems-effects of fire on soil and water. Gen. Tech. Rep. RMRS-GTR42-volume 4. Fort Collins, CO: U.S. Department of Agriculture, Forest Service, Rocky Mountain Research Station: chapter 5.

Novak, P.; Moffat, A. I. B.; Nalluri, C.; Narayanan, R. 2001. Hydraulic structures (3rd ed.). London, UK: Taylor \& Francis Group. 666 p.

Office of Federal Procurement Policy. 2008. Federal Acquisition Regulation (FAR). 48 CFR Part 16.5.

Omang, R. J. 1992. Analysis of the magnitude and frequency of floods and the peakflow gaging network in Montana. Water-Resources Investigations Report 92-4048. Denver, CO: U.S. Geological Survey. 70 p.

Parrett, Charles; Cannon, Susan H.; Pierce, Kenneth L. 2004. Wildfire-related floods and debris flows in Montana in 2000 and 2001. Water-Resources Investigations Report 03-4319. Denver, CO: U.S. Geological Survey. 22 p.

Parrett, Charles; Johnson, D. R. 2004. Methods for estimating flood frequency in Montana based on data through water year 1998. Water-Resources Investigations Report 03-4308. Denver, CO: U.S. Geological Survey. 101 p. 
Quillian, E. W.; Harenberg, W. A. 1982. An evaluation of Idaho stream gaging networks. Open-Fire Report 82-865. Boise, ID: U.S. Geological Survey. 61 p.

Rajagopalan, B.; Lall, U. 1999. A k-nearest-neighbor simulator for daily precipitation and other weather variables. Water Resources Research. 35(10): 3089-3101.

Renschler, C. S. 2003. Designing geo-spatial interfaces to scale process models: the GeoWEPP approach. Hydrological Processes. 17(5): 1005-1017.

Renschler, Chris S. 2008 (March 28-last update). GeoWEPP: the Geo-spatial interface for the Water Erosion Prediction Project [Homepage of GeoWEPP], [Online]. Available: http://www.geog.buffalo.edu/ rensch/geowepp/ [2008, May 6].

Rhodes, Jonathan J. 2005. Comment on "Modeling of the interactions between forest vegetation, disturbances, and sediment yields" by Erkan Istanbulluoglu and others Journal of Geophysical Research. 110: F01012.

Robichaud, P. R. 2000. Fire effects on infiltration rates after prescribed fire in Northern Rocky Mountain forests, USA. Journal of Hydrology: 231-232; 220-229.

Robichaud, P. R. 2005. Measurement of post-fire hillslope erosion to evaluate and model rehabilitation treatment effectiveness and recovery. International Journal of Wildland Fire. 14(4): 475-485.

Robichaud, P. R.; Beyers, J. L.; Neary, D. G. 2000. Evaluating the effectiveness of postfire rehabilitation treatments. Gen. Tech. Rep. RMRS-GTR-63. Fort Collins, CO: U.S. Department of Agriculture, Forest Service, Rocky Mountain Research Station. 85 p.

Robichaud, Peter R.; Elliot, William J.; Pierson, Fredrick B.; Hall, David E.; Moffet, Corey A. 2006 (January 18-last update). Erosion Risk Management Tool (ERMiT) Ver. 2006.01.18. [Homepage of ERMiT Erosion Risk Management Tool], [Online]. Available: http://forest.moscowfsl.wsu.edu/cgi-bin/fswepp/ermit/ermit.pl [2008, March 3].

Robichaud, Peter R.; Elliot, William J.; Pierson, Fredrick B.; Hall, David E.; Moffet, Corey A.; Ashmun, Louise E. 2007. Erosion Risk Management Tool (ERMiT) user manual (version 2006.01.18). Gen. Tech. Rep. RMRS-GTR-188. Fort Collins, CO: U.S. Department of Agriculture, Forest Service, Rocky Mountain Research Station. $24 \mathrm{p}$.

Robison, E. George; Mirati, Albert; Allen, Marganne. 1999. Oregon road/stream crossing restoration guide: spring 1999. Salem, OR: Oregon Department of Forestry. $79 \mathrm{p}$.

Sando, Steven K. 1998. Techniques for estimating peak-flow magnitudue and frequency relations for South Dakota streams. Water-Resources Investigations Report 98-4055. Denver, CO: U.S. Geological Survey. 48 p.

Sauer, V. B. 1974. Flood characteristics of Oklahoma streams. Water-Resources Investigations Report 52-73. Denver, CO: U.S. Geological Survey. 301 p.

Schmidt, Larry J. 1987. Calculated risk: a tool for improving design decisions. In: 18th International Erosion Control Association Conference; 1987 February 26-27; Reno, NV. Proc. Steamboat Springs, CO: International Erosion Control Association: 279-283.

Seaber, P. R.; Kapinos, F. P.; Knapp, G. L. 1987. Hydrologic unit maps. Water-Supply Paper 2294. Denver, CO: U.S. Geological Survey. 63 p.

Shakesby, R. A.; Doerr, S. H.; Walsh, R. P. D. 2000. The erosional impact of soil hydrophobicity: current problems and future research directions. Journal of Hydrology. 231-232: 178-191.

Sirucek, Dean; Olson, Dennis; Butterfly, Henry; Johnson, Steve. 2006. Interagency burned area emergency stabilization \& rehabilitation plan, Red Eagle Fire, watershed resource assessment, hydrology and soils. $24 \mathrm{p}$. 
Springer, Everett P.; Hawkins, Richard H. 2005. Curve number and peakflow responses following the Cerro Grande Fire on a small watershed. In: Moglen, Glenn E., eds. Proceedings: 2005 watershed management conference-managing watersheds for human and natural impacts: engineering, ecological, and economic challenges; 2005 July 19-22; Williamsburg, VA. Alexandria, VA: American Society of Civil Engineers: 459-470.

Story, Mark. 2002. A Excel spreadsheet to calculate peakflows from the 2000 Skalkaho/Valley Complex Fires in Montana. Unpublished draft supplied to author by M. Story.

Story, Mark. 2003. Stormflow Methods. E-mail circulation among Forest Service Region 1 hydrologists. Unpublished note supplied by D. Sirucek, a Flathead Nation Forest hydrologist. On file with author.

Story, Mark; Johnson, Steve; Stuart, Bo; Hickenbottom, Jennifer; Thatcher, Ron; Swartz, Scott. 2006. BAER specialist report, hydrology and roads, Derby Fire. Bozeman, MT: U.S. Department of Agriculture, Forest Service, Northern Region, Gallatin National Forest. 17 p.

Stuart, Bo. 2000. Maudlow Fire, Burned Area Emergency Rehabilitation (BAER) plan. Townsend, MT: U.S. Department of Agriculture, Forest Service, Northern Region, Helena National Forest.

Stuebe, M. M.; Johnston, D. M. 1990. Runoff volume estimation using GIS techniques. Water Resources Bulletin. 26(4): 611-620.

Sumioka, S. S.; Kresch, D. L.; Kasnick, K. D. 1998. Magnitude and frequency of floods in Washington. Water-Resources Investigations Report 97-4277. Denver, CO: Geological Survey. 91 p.

Thomas, Blakemore E.; Hjalmarson, H. W.; Waltemeyer, S. D. 1997. Methods for estimating magnitude and frequency of floods in the southwestern United States. Water-Supply Paper 2433. Denver, CO: Geological Survey. 195 p.

U.S. Department of Agriculture, Agricultural Research Service and Forest Service. 2008 (January 23-last update). Cligen Weather Generator, expanded and improved [Homepage of Cligen], [Online]. Available: http://topsoil.nserl.purdue.edu/ nserlweb/weppmain/cligen/ [2008, February 7].

U.S. Department of Agriculture, Forest Service. 2003. Forest Service Manual 7712.11, Exhibit 01. Available at: www.fs.fed.us/im/directives/dughtml/fsm.html [2007, May 28].

U.S. Department of Agriculture, Forest Service. 2007 (January 1-last update). Remote Sensing Applications Center: What is a BARC? [Homepage of BARC], [Online]. Available: http://www.fs.fed.us/eng/rsac/baer/barc.html [2008, February 7].

U.S. Department of Agriculture, Geological Survey 2007 (March 14-last update). Welcome to StreamStat [Homepage of StreamStat], [Online]. Available at: http:// water.usgs.gov/osw/streamstats/index.html [2008, May 11].

U.S. Department of Agriculture, Natural Resources Conservation Service. 2005a (January 1-last update). Hydraulics and Hydrology: Tools and ModelsWinTR-20 [Homepage of WinTR-20], [Online]. Available: http://www.wsi.nres. usda.gov/products/W2Q/H\&H/Tools_Models/WinTR20.html [2008, October 24].

U.S. Department of Agriculture, Natural Resources Conservation Service. 2005 (January 1-last update). Hydraulics and Hydrology: Tools and ModelsWinTR-55 [Homepage of WinTR-55], [Online]. Available: http://www.wsi.nrcs. usda.gov/products/W2Q/H\&H/Tools_Models/WinTR55.html [2008, February 7].

U.S. Department of Agriculture, Soil Conservation Service. 1972. Hydrology. In: National engineering handbook. Washington, DC: U.S. Department of Agriculture, Soil Conservation Service: section 4. 
U.S. Department of Agriculture, Soil Conservation Service. 1975. Urban hydrology for small watersheds. Technical Release 55. Chester, PA: U.S. Department of Agriculture, Soil Conservation Service. $91 \mathrm{p}$.

U.S. Department of Agriculture, Soil Conservation Service. 1986. Urban hydrology for small watersheds. Technical Release 55. Chester, PA: U.S. Department of Agriculture, Soil Conservation Service. $156 \mathrm{p}$.

U.S. Department of Agriculture, Soil Conservation Service. 1991. Engineering field handbook: chapter 2 - estimating runoff. In: National engineering handbook. Washington, DC: U.S. Department of Agriculture, Soil Conservation Service: part 650 .

U.S. Weather Bureau. 1961. Rainfall frequency atlas of the United States. Technical Paper 40. Silver Spring, MD: National Oceanic and Atmospheric Administration. $115 \mathrm{p}$.

Vaill, J. E. 2000. Analysis of the magnitude and frequency of floods in Colorado. Water-Resources Investigations Report 99-4190. Denver, CO: Geological Survey. $35 \mathrm{p}$.

Waananen, A. O.; Crippen, J. R. 1977. Magnitude and frequency of floods in California. Water-Resources Investigations Report 77-21. Denver, CO: Geological Survey. 96 p.

Waltemeyer, S. D. 1996. Analysis of the magnitude and frequency of peak discharge and maximum observed peak discharge in New Mexico. Water-Resources Investigations Report 96-4112. Denver, CO: Geological Survey. 79 p.

Watkins, L. H.; Fiddes, D. 1984. Highway and urban hydrology in the tropics. London, UK: Pentech Press Limited. 206 p.

White, D. 1988. Grid-based application of runoff curve numbers. Journal of Water Resources Planning and Management. 114(6): 601-612. 


\section{Appendix A-Example Data and Interview Forms}

Interview questionnaire for BAER teams

Survey date: 14 Mar 07

Survey location: Grangeville, ID

Interviewee name:

Address: Nez Perce National Forest, Grangeville, ID

Telephone number:

E-mail:

Please provide the information of BAER activities that you participated in as much as you can remember, starting from the most recent BAER activity to year 1999.

\begin{tabular}{|l|l|c|l|}
\hline Year & \multicolumn{1}{|c|}{ Fire name } & Region & \multicolumn{1}{c|}{ National Forest } \\
\hline 2000 & Three Bears, Wilderness Cx & 1 & Bitterroot and Nez Perce \\
\hline 2000 & Burnt Flats & 1 & Nez Perce (Clearwater) \\
\hline 2000 & Valley Cx & 1 & Bitterroot \\
\hline 2001 & Taco & 1 & Nez Perce (Salmon River) \\
\hline 2002 & Kelly Creek & 1 & Nez Perce (Salmon River) \\
\hline 2003 & Berg 3 & 1 & Nez Perce (Salmon River) \\
\hline 2003 & Fiddle & 1 & Nez Perce (Malmon River) \\
\hline 2003 & Wilderness Cx & 1 & $\begin{array}{l}\text { Nez Perce (Red River, Moose } \\
\text { Creek) }\end{array}$ \\
\hline 2003 & Slims Cx & 1 & Nez Perce (Clearwater) \\
\hline 2005 & Blackerby & 1 & Nez Perce (Clearwater) \\
\hline 2005 & China 10 & 1 & Nez Perce (Moose Creek) \\
\hline 2005 & Upper Meadow & 1 & Nez Perce (Salmon River) \\
\hline 2005 & West Fork & 1,6 & $\begin{array}{l}\text { Nez Perce (Salmon River), } \\
\text { Wallowa-Whitman (Hells } \\
\text { Canyon NRA) }\end{array}$ \\
\hline 2006 & Heavens Gate & 1 & Nez Perce (Moose Creek) \\
\hline 2006 & Meadow & 1,6 & $\begin{array}{l}\text { Nez Perce (Salmon River), } \\
\text { Wallowa-Whitman (Hells } \\
\text { Canyon NRA) }\end{array}$ \\
\hline 2007 & Poe Cabin & 1 & $\begin{array}{l}\text { Nez Perce (Red River, Salmon } \\
\text { River) }\end{array}$ \\
\hline 2007 & Rattlesnake & & \\
\hline
\end{tabular}

Please let us know if you have ANY BAER reports (FS-2500-8) including initial, interim, and final reports and any BAER related information (gray literature). 


\section{BAER Report Questionnaire}

What kind of method did you use to calculate/estimate the values in the following section in a BAER report? For example, if you came up with that value from your experience, write "Personal Experience." If you have the reference publication that you used for that method, please let us know.

Part IV - Hydrologic Design Factors

A. Estimated vegetation Recovery Period, (years): Personal experience, forest ecologist

B. Design Chance of Success, (percent): Professional judgment

C. Equivalent Design Recurrence Interval, (years): Usually 10 years

D. Design Storm Duration, (hours): For snowmelt, 24 hours; for low elevation storm flow, 6 hours; sometimes 30 min

E. Design Storm Magnitude, (inches): NOAA Atlas

F. Design Flow, $\left(\mathrm{cfs} / \mathrm{mi}^{2}\right)$ : For low elevation storm flow, NRCS CN method; for mid, high elevation, spring snowmelt RO, USGS StreamStats

G. Estimated Reduction in Infiltration, (percent): Actual infiltration tests on burned/unburned area

H: Adjusted Design Flow, (cfs/mi $\left.{ }^{2}\right)$ : For low elevation storm flow, NRCS CN method; for mid, high elevation, spring snowmelt RO, USGS StreamStats; modify moderate and high severity burn area $R O \times 2(100 \%$ increase $)$ and estimate peak flow for 1st year after fire 


\section{Road Treatment Questionnaire}

Please answer following questions based on your general experience.

What are the three most frequently used road treatments?

The most: Culvert upsize

Second most: Rolling/armored dips

Third most: Additional relief culvert

Reason to choose the treatment: Values at risk

Was there an alternative road treatment available?

What do you think are the three most effective road treatments?

The most: Culvert upsize

Second most: Culvert removal

Third most: Rolling/armored dips

Reason to choose the treatment:

How do you calculate road treatment cost (be careful to ask this; i.e., was there a standard/guideline to estimate road treatment cost?)?

Engineer's suggestion; regional cost guide

Any comment on BAER road treatments: NRCS CN method is highly subjective to $C N$ input by user; Nez Perce not using WATBAL; check upstream to include debris to estimate RO; too much debris expected, trash rack and outburst (winged) inlet is recommended; hydromulch culslopes; usually BAER team members have BAER case or bag 


\section{Aftermath Road Treatment Questionnaire}

Please answer the following questions using the table below. If you have any written report or documentation related to the following questions, please let us know. (This questions best to ask to local district hydrologists).

Was there a large (or damaging) storm/runoff event in BAER road treatment areas?

If so, please let us know the following information.

(1) Name and (2) Year of BAER treated fires, and (3) Location of BAER road treatment areas.

(4) When the large (or damaging) storm/runoff events occurred (after the road treatments).

(5) Magnitude of storm and (6) Magnitude of runoff, such as precipitation and runoff amount.

(7) Did the road treatment fail or hold?

(8) If failed, what do you think is the primary reason for this road treatment to fail?

(9) If failed, did the treated road section fail too or did only the road treatment fail?

(10)After this road treatment failed, what did you do (failure aftermath)?

\begin{tabular}{|c|c|c|l|}
\hline$(1)$ & Fire name & Blackerby Fire & \\
\hline$(2)$ & Fire year & 2005 & \\
\hline$(3)$ & Fire/BAER location & Grangeville, ID & \\
\hline$(4)$ & When storm/runoff? & 19 May 06 & \\
\hline$(5)$ & Storm magnitude (inch) & 0.78 inch for 30 min & \\
\hline$(6)$ & Runoff magnitude (cfs) & $\begin{array}{l}71 c^{c f s}\left(56 c f s \text { mi }^{-2}\right) \text { for } \\
\text { flood flow; } 620 \text { cfs }(492 \\
\left.c f \text { mi }^{-2}\right) \text { for debris flow } \\
\text { Storm flow failed to pass }\end{array}$ & \\
\hline$(7)$ & Fail/Hold & $\begin{array}{c}\text { Exceeding culvert } \\
\text { capacity (35 cfs) }\end{array}$ & \\
\hline$(8)$ & $\begin{array}{c}\text { Reason for failure } \\
\text { Only treatment }\end{array}$ & \\
\hline$(9)$ & $\begin{array}{c}\text { Road section failed/only } \\
\text { treatment? }\end{array}$ & $\begin{array}{c}\text { Failure aftermath } \\
\text { Cleanout }\end{array}$ & \\
\hline
\end{tabular}




\section{Appendix B-List of Gray Literature from BAER Interviews}

\section{Region 1}

Nick Gerhardt

Gerhardt, Nick. 2005. [Personal notes on file with author.] September 2. China 10Flow calculations using USGS regression method.

Gerhardt, Nick. 2006. [Personal notes on file with author.] June 26. NRCS post-fire stormflow model, step-by-step.

Gerhardt, Nick. 2006. [Personal notes on file with author.] December 18. Characterization of a post-fire debris flow and flood, Blackerby Fire, Idaho.

Parrett, Charles; Johnson, D. R. 2004. Methods for estimating flood frequency in Montana based on data through water year 1998. Water-Resources Investigations Report 03-4308. Denver, CO: U.S. Geological Survey. 101 p.

\section{Richard Jones}

Cahoon, Joel. (2005, August 11-last update). Circular Culvert Design Spreadsheet [Online]. Available: http://www.wti.montana.edu/Documents/Reports/PDF/CMP Hydraulics.xls [2008, July 8].

Cerrelli, G. A. 2005. FIRE HYDRO, a simplified method for predicting peak discharges to assist in the design of flood protection measures for western wildfires. In: Moglen, Glenn E., eds. Proceedings: 2005 watershed management conferencemanaging watersheds for human and natural impacts: engineering, ecological, and economic challenges; 2005 July 19-22; Williamsburg, VA. Alexandria, VA: American Society of Civil Engineers: 935-941.

Jones, Richard. 1996. [Personal notes on file with author.] January 1. The CLWFLOOD program predicts flood frequencies using eight procedures (revised).

Jones, Richard. 2000. September 11. BAER report, Crooked Fire, Clearwater National Forest, Idaho. Orofino, ID: U.S. Department of Agriculture, Forest Service, Northern Region, Clearwater National Forest. 15 p.

Jones, Richard; Mital, James. 2003. September 26. Burned area report, Beaver Lakes Complex, Clearwater National Forest, Idaho. Orofino, ID: U.S. Department of Agriculture, Forest Service, Northern Region, Clearwater National Forest. 11 p.

Jones, Richard; Mital, James. 2003. September 26. BAER report, Hopeful 2 Fire, Clearwater National Forest, Idaho. Orofino, ID: U.S. Department of Agriculture, Forest Service, Northern Region, Clearwater National Forest. 10 p.

Jones, Richard; Mital, James. 2003. September 26. BAER report, Bear's Oil, Wendover, Pleasant, and Rhodes Fires, Clearwater National Forest, Idaho. Orofino, ID: U.S. Department of Agriculture, Forest Service, Northern Region, Clearwater National Forest. $12 \mathrm{p}$.

Mital, James. 2000. October 16. BAER report, Snow Creek Fire, Clearwater National Forest, Idaho. Orofino, ID: U.S. Department of Agriculture, Forest Service, Northern Region, Clearwater National Forest. 12 p. 
Mital, James. 2000. October 16. BAER report, Elizabeth Fire, Clearwater National Forest, Idaho. Orofino, ID: U.S. Department of Agriculture, Forest Service, Northern Region, Clearwater National Forest. 10 p.

Mital, James. 2001. September 17. BAER report, Walton Fire, Clearwater National Forest, Idaho. Orofino, ID: U.S. Department of Agriculture, Forest Service, Northern Region, Clearwater National Forest. 11 p.

Snook, Ed; Jones, Richards [and others]. 2006. September 13. Burned area report, Gash Creek Incident Fire, Bitterroot National Forest, Montana. Hamilton, MT: U.S. Department of Agriculture, Forest Service, Northern Region, Bitterroot National Forest. $13 \mathrm{p}$.

\section{Rick Patten}

Patten, Rick. 2006. October 31. Burned area report, Ulm Peak Fire, Idaho Panhandle National Forests, Idaho. Coeur d'Alene, ID: U.S. Department of Agriculture, Forest Service, Northern Region, Idaho Panhandle National Forests. 27 p.

\section{Dean Sirucek}

Gardner, Beth; Boelman, Shawn. 2004. [Personal notes on file with author.] February 17. Crazy Horse BAER-modifications on item C. of the original BAER specsinstall corrugated metal pipe. $29 \mathrm{p}$.

Interagency Burned Area Emergency Response Team. 2003. August 29. Interagency Burned Area Emergency Stabilization and Rehabilitation Plan, Robert and Trapper Creek Fires, Water Resource Assessment. Hungry Horse and West Glacier, MT: U.S. Department of Agriculture, Forest Service, Northern Region, Flathead National Forest, and National Park Service, Glacier National Park. 20 p.

Sirucek, Dean; Olson, Dennis; Butterfly, Henry; Johnson, Steve. 2006. Interagency burned area emergency stabilization \& rehabilitation plan, Red Eagle Fire, watershed resource assessment, hydrology and soils. $24 \mathrm{p}$.

\section{Mark Story}

Cahoon, Joel. (2005, August 11-last update). Circular Culvert Design Spreadsheet [Online]. Available: http://www.wti.montana.edu/Documents/Reports/PDF/CMP_ Hydraulics.xls [2008, July 8].

Story, Mark; Johnson, Steve; Stuart, Bo; Hickenbottom, Jennifer; Thatcher, Ron; Swartz, Scott. 2006. September. BAER specialist report, hydrology and roads, Derby Fire. Bozeman, MT: U.S. Department of Agriculture, Forest Service, Northern Region, Gallatin National Forest. 17 p.

Story, Mark. 2003. [Personal notes on file with author.] September. Stormflow methods.

\section{Bo Stuart}

Story, Mark; Johnson, Steve; Stuart, Bo; Hickenbottom, Jennifer; Thatcher, Ron; Swartz, Scott. 2006. September. BAER specialist report, hydrology and roads, Derby Fire. Bozeman, MT: U.S. Department of Agriculture, Forest Service, Northern Region, Gallatin National Forest. 17 p.

Stuart, Bo. 2000. September 26. Maudlow Fire, Burned Area Emergency Rehabilitation (BAER) plan. Helena, MT: U.S. Department of Agriculture, Forest Service, Northern Region, Helena National Forest.

Stuart, Bo. 2003. September 22. Snow-Talon Fire Burned Area Emergency Rehabilitation (BAER) Plan. Helena, MT: U.S. Department of Agriculture, Forest Service, Northern Region, Helena National Forest. 57 p. 


\section{Region2}

\section{Greg Bevenger}

Johnson, Steve; Gould, Jessica. 2003. Burned area emergency stabilization and rehab plan, Blackfoot Complex Fires, Flathead NF, watershed resource assessment. Libby, MT: U.S. Department of Agriculture, Forest Service, Northern Region, Kootenai National Forest. $10 \mathrm{p}$.

Solt, Adam; Muir, Mark. 2006. July 8. Warm Fire-hydrology and watershed report. Richfield, UT: U.S. Department of Agriculture, Forest Service, Intermountain Region, Fishlake National Forest. 9 p.

Souders, Charles. 2006. July 8. Warm Fire burned area, Kaibab NF, Burned Area Emergency Response assessment, soil resource conditions. Silver City, NM: U.S. Department of Agriculture, Forest Service, Southwest Region, Gila National Forest. 9 p.

\section{Region 3}

\section{Robert Lefevre}

Eychaner, James H. 1984. Estimation of magnitude and frequency of floods in Pima County, Arizona, with comparisons of alternative methods. Water-Resources Investigations Report 84-4142. Denver, CO: U.S. Geological Survey. 69 p.

Furniss, Michael J. (2002-last update). The six-D system for effective waterbars [Online]. Available: http://www.fs.fed.us/r5/baer/six-d.html [2008, July 13].

Lefevre, Robert. [Personal notes on file with author.] Greg's Curve Number thoughts.

Lefevre, Robert; [and others]. 2002. June 18. BAER report, Bullock Fire, Coronado National Forest, Arizona. Tucson, AZ: U.S. Department of Agriculture, Forest Service, Southwestern Region, Coronado National Forest. 14 p.

Pearthree, Philip A.; Youberg, Ann. 2006. Recent debris flows and floods in southern Arizona. Arizona Geology 36(3). 6 p.

Roeske, R. N. 1978. Methods for estimating the magnitude and frequency of floods in Arizona. Arizona Department of Transportation report: ADOT-RS-15(121) final report. Phoenix, AZ: U.S. Department of Transportation, Federal Highway Administration. $82 \mathrm{p}$.

Solomon, Rhey; Maxwell, Jim; Shaw, Doug; Schmidt, Larry. 1981. June 18. Watershed condition hydrology overview. Hydrology Notes. Albuquerque, NM: U.S. Department of Agriculture, Forest Service, Southwestern Region.

Wildland Fire Lessons Learned Center. 2006. Burned Area Emergency Response (BAER) Lessons Learned. Scratchline, Issue 15. 6 p.

U.S. Forest Service Coronado National Forest. 2003. Aspen Fire, Coronado National Forest, BAER hydrology report. Tucson, AZ: U.S. Department of Agriculture, Forest Service, Southwestern Region, Coronado National Forest: 24-30.

\section{Greg Kuyumajian}

Gallaher, Bruce M.; Koch, Richard J. 2004. September. Cerro Grande Fire impacts to water quality and stream flow near Los Alamos National Laboratory: results of four years of monitoring. LA-14177. Springfield, VA: U.S. Department of Commerce, National Technical Information Service. $195 \mathrm{p}$.

Johnson, Ada Suzanne. 2003. Aspen Fire 2003 treatment success monitoring report. Tucson, AZ: U.S. Department of Agriculture, Forest Service, Southwest Region, Coronado National Forest. 21 p.

Kuyumajian, Greg. 2007. [Personal notes on file with author.] April 24. BAER design storms, FY 2000-2003, southwestern region, USDA Forest Service. 


\section{Grant Loomis}

Baldys, Stanley III; Hjalmarson, H. W. 1994. Effects of controlled burning of chaparral on streamflow and sediment characteristics, East Fork Sycamore Creek, central Arizona. Water-Resources Investigations Report 93-4102. Denver, CO: U.S. Geological Survey. 33 p.

Reed, William B.; Schaffner, Mike. 2007. Effects of wildfire in the mountainous terrain of southeast Arizona: an empirical formula to estimate 5-year peak discharge from small post-burn watersheds. NOAA Technical Memorandum NWS WR-279. Springfield, VA: U.S. Department of Commerce, National Technical Information Service. $22 \mathrm{p}$.

Reneau, Steven L.; Kuyumajian, Gregory A. 2004. December. Rainfall-runoff relations in Pueblo Canyon, New Mexico, after the Cerro Grande Fire. Los Alamos National Laboratory Report LA-UR-04-8810. Los Alamos, NM: Los Alamos National Laboratory. $32 \mathrm{p}$.

Schaffner, Mike; Reed, William B. 2005. (2005-last update). Effects of wildfire in the mountainous terrain of southeast Arizona: post-burn hydrologic response of nine watersheds [Homepage of 2005 Technical Attachments 05-01], [Online]. Available: http://www.wrh.noaa.gov/wrh/TA05.php [2008, July 25].

White, William D. 1994. Geomorphic response of six headwater basins fifteen years after the La Mesa Fire, Bandelier National Monument. In: Allen, Craig D, ed. Fire effects in southwestern forests: proceedings of the second La Mesa Fire symposium; 1994 March 29-31; Los Alamos, NM. Proc. RM-GTR-286. Fort Collins, CO: U.S. Department of Agriculture, Forest Service, Rocky Mountain Research Station: 95-113.

\section{Region 4}

\section{Mike Dixon}

Dixon, Mike. 2008. [Personal notes on file with author.] March 17. 100 year flood flow culvert analysis.

\section{Terry Hardy and John Thorton}

Schmidt, Larry J. 1987. Calculated risk: a tool for improving design decisions. In: 18th International Erosion Control Association Conference; 1987 February 26-27; Reno, NV. Proc. Steamboat Springs, CO: International Erosion Control Association: 279-283. Stream Notes; 1998 October. Fort Collins, CO: U.S. Department of Agriculture, Forest Service, Rocky Mountain Research Station. 5 p.

BAER—Burned Area Emergency Response burn severity field data sheet.

\section{Region 5}

\section{Mike Bradshaw}

Frazier, Jim; [and others]. 2005. March 31. BAER report, Cedar Fire, Cleveland National Forest, California. San Diego, CA: U.S. Department of Agriculture, Forest Service, Pacific Southwest Region, Cleveland National Forest. 12 p.

\section{Alex Janicki}

Janicki, Alex [and others]. 2003. July 8. BAER report, Woodlot Fire, Stanislaus National Forest, California. Sonora, CA: U.S. Department of Agriculture, Forest Service, Pacific Southwest Region, Stanislaus National Forest. 12 p. 


\section{Carolyn Napper}

Napper, Carolyn. 2006. June 15. BAER report, Arrastre Fire, San Bernardino National Forest, California. San Bernardino, CA: U.S. Department of Agriculture, Forest Service, Pacific Southwest Region, San Bernardino National Forest. 8 p.

Stamer, Marc [and others]. 2006. January 31. BAER report, Plunge Fire, San Bernardino National Forest, California. San Bernardino, CA: U.S. Department of Agriculture, Forest Service, Pacific Southwest Region, San Bernardino National Forest. $11 \mathrm{p}$.

\section{Gregory Napper}

Napper, Gregory S. 1999. [Unpublished BAER course material on file with author.] May 3-7. Burned Area Emergency Rehabilitation techniques course.

\section{Mike Parenti}

Parenti, M. [and others]. 2002. [Unpublished hydrology report on file with author.] June 11. Hydrologist Report, Arrowhead Fire, San Bernardino National Forest.

Parenti, M. [and others]. 2003. [Unpublished guideline on file with author.] May 1. Modified Rational GIS flow model users guide 1.0.

Parenti, M. [and others]. 2003. [Unpublished guideline on file with author.] May 1. Revised Universal Soil Loss Equation GIS model users guide 1.0. 


\section{Appendix C_USGS Regression Methods}

The USGS regression methods were developed to estimate peak flow discharge for gaged and ungaged natural flow streams, which were categorized into (1) a gaged site, (2) a site near a gaged site near the same stream, and (3) an ungaged site. StreamStats are available for many states (fig. 1), which is a webbased tool used to obtain streamflow information (http://water.usgs.gov/osw/ streamstats/index.html), and estimate peak flow in a given location. For most other western United States, two USGS regression methods for ungaged sites are available. Thomas and others (1997) developed the USGS regression methods in the southwestern United States (fig. C.1). Additionally, each state has one or more publications of USGS regression methods of its own. This report summarizes the USGS regression methods by Thomas and others (1997) and other state-by-state USGS regression methods for ungaged sites in the western United States. Peak flow discharge for gaged sites and sites near gaged site near stream are estimated by the following methods.

\section{Gaged Sites}

Weighted estimates were considered to be the best estimates of flood frequency at a gaged site, and the following equation was used for the weighted estimate (Sauer 1974):

$$
Q_{T(w)}=\frac{Q_{T(s)} N+Q_{T(r)} E}{N+E}
$$

Where:

$$
\begin{aligned}
& Q_{T(w)}= \begin{array}{l}
\text { weighted discharge, in } \mathrm{ft}^{3} / \mathrm{sec}, \text { for } T \text {-year recurrence } \\
\text { interval }
\end{array} \\
& Q_{T(s)}=\begin{array}{l}
\text { station value of the discharge, in } \mathrm{ft}^{3} / \mathrm{sec}, \text { for } T \text {-year } \\
\text { recurrence interval }
\end{array} \\
& Q_{T(r)=} \begin{array}{l}
\text { regression value of the discharge, in } \mathrm{ft}^{3} / \mathrm{sec}, \text { for } T \text {-year } \\
\text { recurrence interval }
\end{array} \\
& N=\begin{array}{l}
\text { number of years of station data used to compute } Q_{T(s)} \\
E=
\end{array}
\end{aligned}
$$



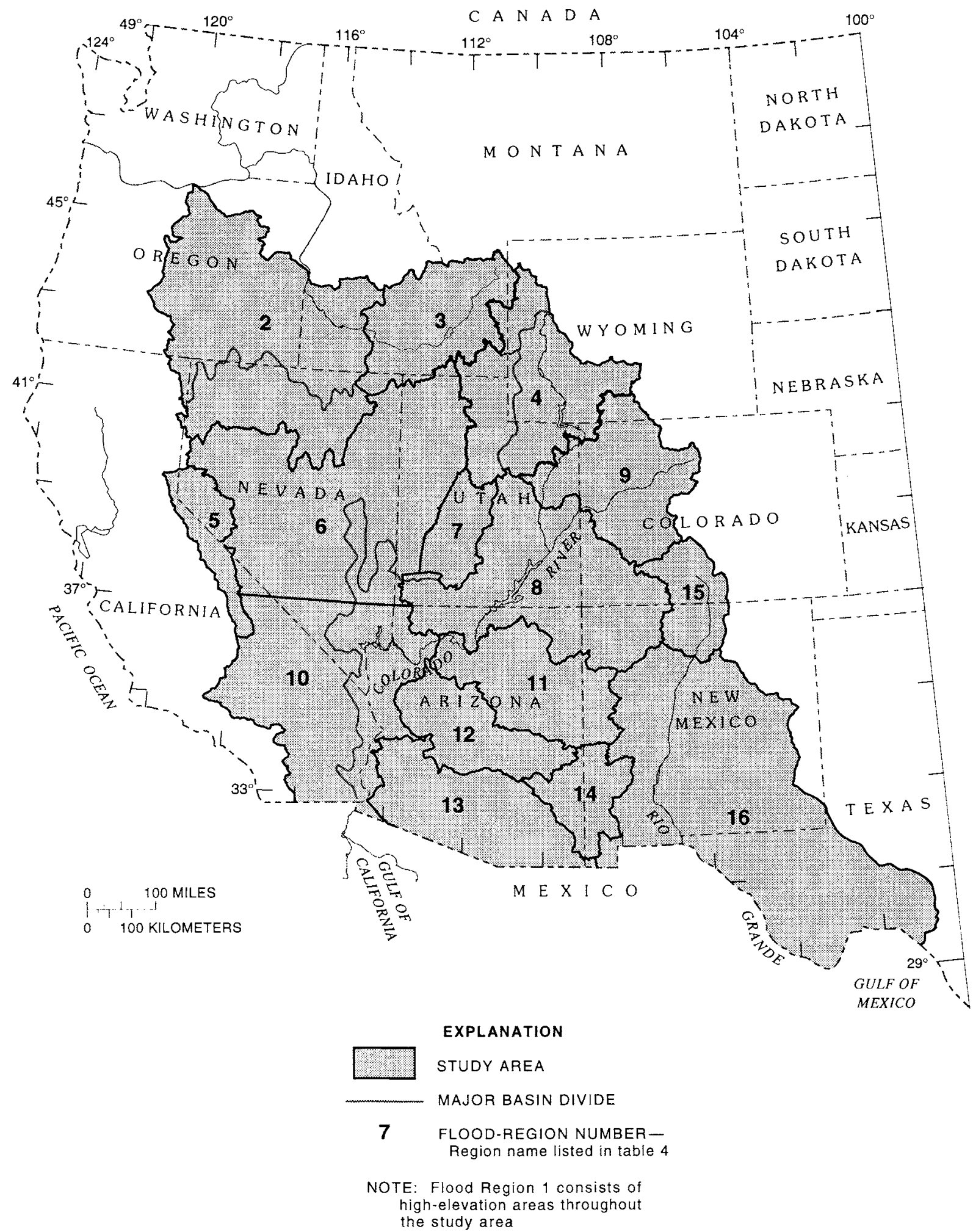

Figure C.1—Flood Regions in the Southwestern United States (Thomas and others 1997). 


\section{Sites Near Gaged Sites on the Same Stream}

Flood-frequency relations at sites near gaged sites on the same stream can be estimated using a ratio of drainage area for the ungaged and gaged sites. The drainage-area ratio should be approximately between 0.5 and 1.5. If ungaged and gaged basins have similar characteristics in topography, geology, and vegetation, and the drainage-area ratio requirement, the following equations can be used for peak flow:

$$
Q_{T(u)}=Q_{T(g)}\left(A_{u} / A_{g}\right)^{x}
$$

Where:

$$
\begin{aligned}
& Q_{T(u)}=\begin{array}{l}
\text { peak flow, in } \mathrm{ft}^{3} / \mathrm{sec} \text {, at ungaged site for } T \text {-year recurrence } \\
\text { interval }
\end{array} \\
& Q_{T(g)}=\text { peak flow, in } \mathrm{ft}^{3} / \mathrm{sec} \text {, at gaged site for } T \text {-year recurrence } \\
& \text { interval } \\
& A_{u}=\text { drainage area, in } \mathrm{mi}^{2} \text {, at ungaged site } \\
& A_{g}=\text { drainage area, in } \mathrm{mi}^{2} \text {, at gaged site } \\
& x=\text { exponent for each flood region as follows: }
\end{aligned}
$$

\begin{tabular}{lcc}
\hline \multicolumn{1}{c}{ Flood region } & & \\
\cline { 1 - 2 } Name & Number & Exponent, $\boldsymbol{x}$ \\
\hline High-Elevation & 1 & 0.8 \\
Northwest & 2 & 0.7 \\
South-Central Idaho & 3 & 0.7 \\
Northeast & 4 & 0.7 \\
Eastern Sierra & 5 & 0.8 \\
Northern Great Basin & 6 & 0.6 \\
South-Central Utah & 7 & 0.5 \\
Four Corners & 8 & 0.4 \\
Western Colorado & 9 & 0.5 \\
Southern Great Basin & 10 & 0.6 \\
Northeastern Arizona & 11 & 0.6 \\
Central Arizona & 12 & 0.6 \\
Southern Arizona & 13 & 0.5 \\
Upper Gila Basin & 14 & 0.5 \\
Upper Rio Grande Basin & 15 & 0.5 \\
Southeast & 16 & 0.4 \\
\hline
\end{tabular}

Applicable when the drainage area ratio $\left(A_{u} / A_{g}\right)$ is between 0.5 and 1.5.

\section{Ungaged Sites}

Flood-frequency relations at ungaged sites were estimated using the regional models of regression equations and developed using basin and climate characteristics as explanatory variables in the flowing section. There are three models in equations C.3 through C.8 to express the relation between peak flow and basin and climate characteristics. The most common relation is in the following form: 


$$
Q_{T}=a \mathrm{~A}^{b} \mathrm{~B}^{c}
$$

The following linear relation is obtained by logarithmic transformation:

$$
\log Q_{T}=\log a+b \log A+c \log B+\ldots,
$$

Where:

$$
\begin{aligned}
Q_{T} & =\text { peak flow, in } \mathrm{ft}^{3} / \mathrm{sec}, \text { for } T \text {-year recurrence interval } \\
A \text { and } B & =\text { explanatory variables } \\
a, b, c & =\text { regression coefficients }
\end{aligned}
$$

Drainage area is the most significant explanatory variable, and in some cases, the relation between the logarithm of peak flow $\left(Q_{T}\right)$ and the logarithm of drainage area is not linear. The following form of equations is used in such cases:

$$
Q_{T}=10^{\left(a+b A R E A^{x}\right)} B^{c}
$$

or the logarithmic transformation:

$$
\log Q_{T}=a+b \mathrm{AREA}^{x}+c \log B+\ldots
$$

Where:

$$
\begin{aligned}
\text { AREA } & =\text { drainage area } \\
B & =\text { other basin or climatic characteristic } \\
x & =\begin{array}{l}
\text { exponent for AREA for which the relation is made } \\
\text { linear }
\end{array}
\end{aligned}
$$

The third form of equations is another method to account for a nonlinear relation between the logarithm of $Q_{T}$ and the logarithm of drainage area.

$$
Q_{T}=a \operatorname{AREA}^{b}(B-d)^{c},
$$

or the logarithmic transformation:

$$
\log Q_{T}=\log a+b \log \mathrm{AREA}+c \log (B-d)+\ldots,
$$

Where:

$$
\begin{aligned}
d= & \text { a constant, which is less than the minimum value } \\
& \text { of } B \text {, for which the relation is made linear }
\end{aligned}
$$

\section{Explanatory Variables}

For the purpose of the report by Thomas and others (1997), six basin and climate characteristics are referred to as explanatory variables and are used as terms in the model equations. The abbreviation for each variable and method of measuring the variable are as follows:

1. AREA is the drainage area, in square miles, and is determined by planimetering the contributing drainage area on the largest scale topographic map available. 
2. ELEV is the mean basin elevation, in feet above sea level, and is determined by placing a transparent grid over the drainage-basin area, which is drawn on the largest scale topographic map available. The elevations of a minimum of 20 equally spaced points are determined, and the average of the points is taken. As many as 100 points may be needed for large basins.

3. PREC is the mean annual precipitation, in inches, and is determined by placing a transparent grid over an isohyetal map of mean annual precipitation. The drainage-area boundary is drawn on the map, the mean annual precipitation is determined at each grid intersection, and the values are averaged for the basin.

4. EVAP is the mean annual free water-surface evaporation, in inches, and was determined for gages sites by linear interpolation between the isolines of map 3 from Farnsworth and others (1982). The value used for the regression equations was the value at the gaged-site location; therefore, in the application of the regression equations, the study-site location should be used. To use the methods from the report by Thomas and others (1997), EVAP should be estimated for the study site by linear interpolation between the isolines of EVAP shown in figures C.2, C.7, and C.22.

5. LAT is the latitude of the gaged site, in decimal degree, and is determined using the largest scale topographic map available. The value used for the regression equations was the value at the gaged-site location; therefore, in the application of the regression equations, the study-site location should be used. Decimal degrees are the minutes and seconds of the latitude converted to a decimal.

6. LONG is the longitude of the gaged site, in decimal degrees, and is determined using the largest scale topographic map available. The value used for the regression equations was the value at the gaged-site location; therefore, in the application of the regression equations, the study-site location should be used. Decimal degrees are the minutes and seconds of the longitude converted to a decimal.

The USGS regression methods for regions developed by Thomas and others (1997) are shown in fig. C.1 and tables C.1 to C.16. Additionally, other state-bystate USGS regression methods for ungaged sites in the western United States follow in the form of tables and figures arranged in alphabetical order. 


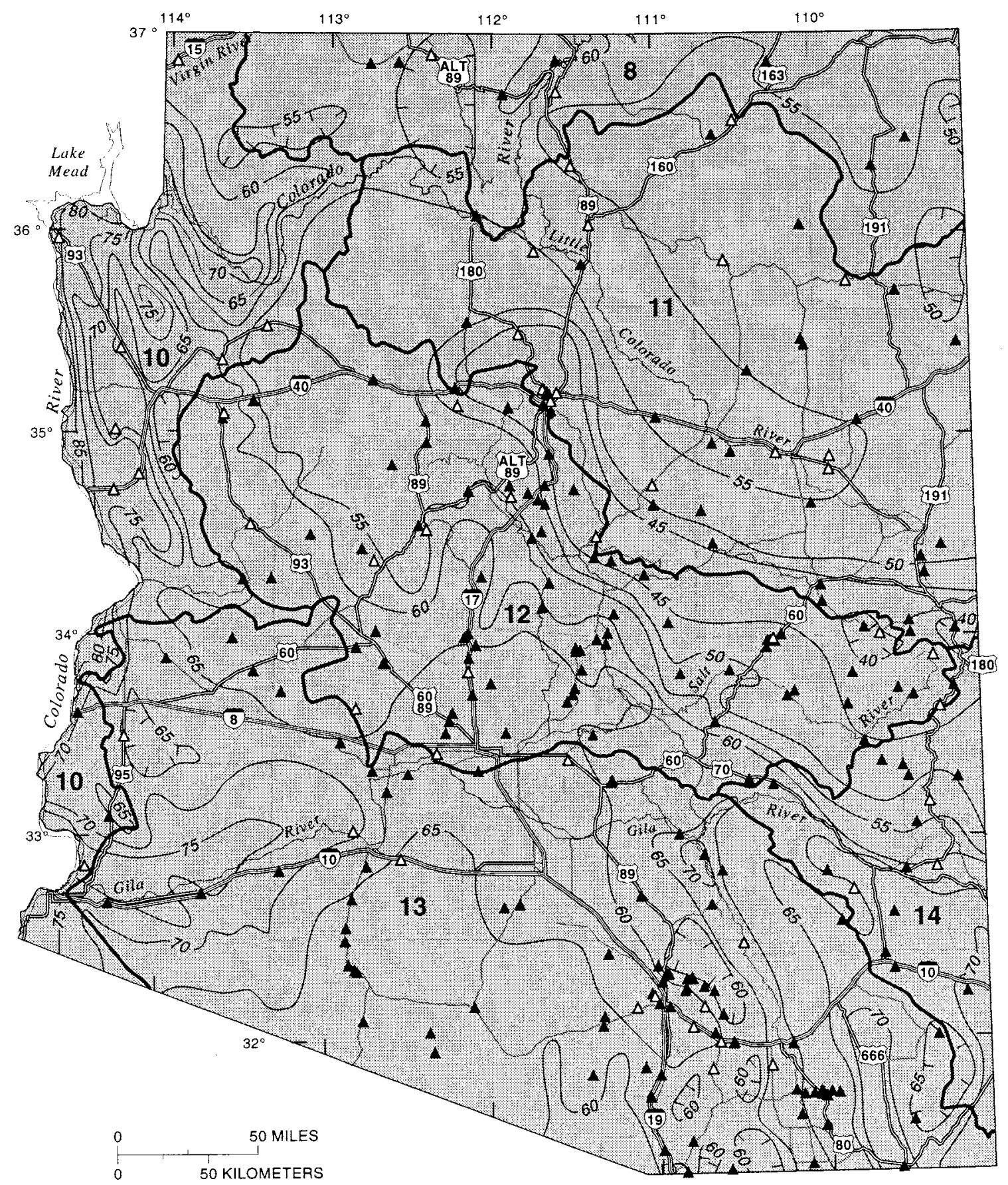

EXPLANATION

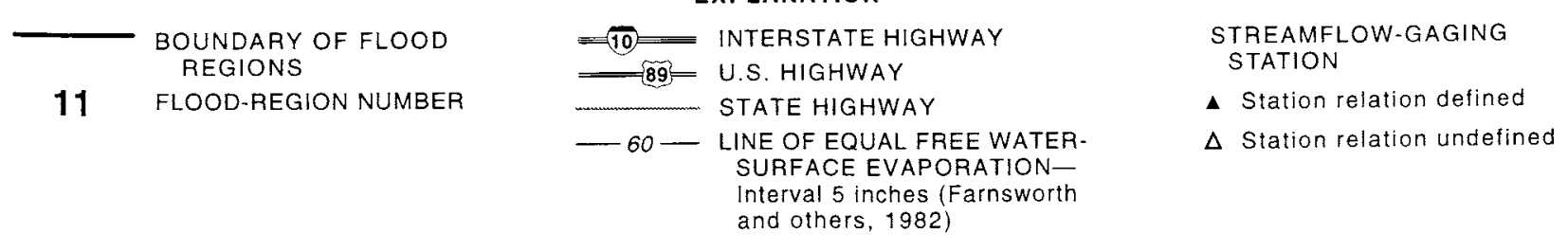

Figure C.2-Free water-surface evaporation for Arizona (Farnsworth and others 1982; Thomas and others 1997). 


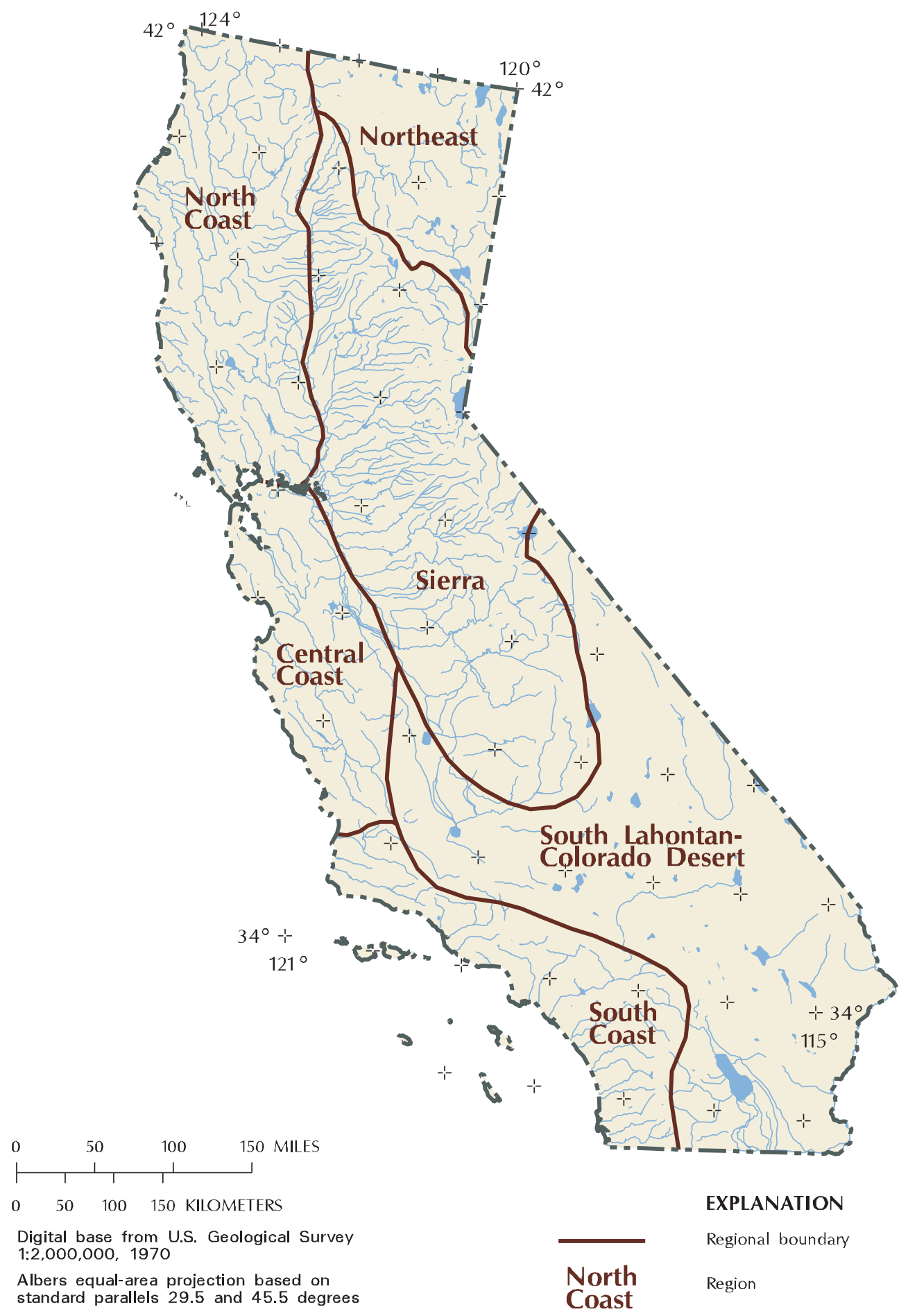

Figure C.3-Hydrologic Regions of California (Jennings and others 1994; Waananen and Crippen 1977). 


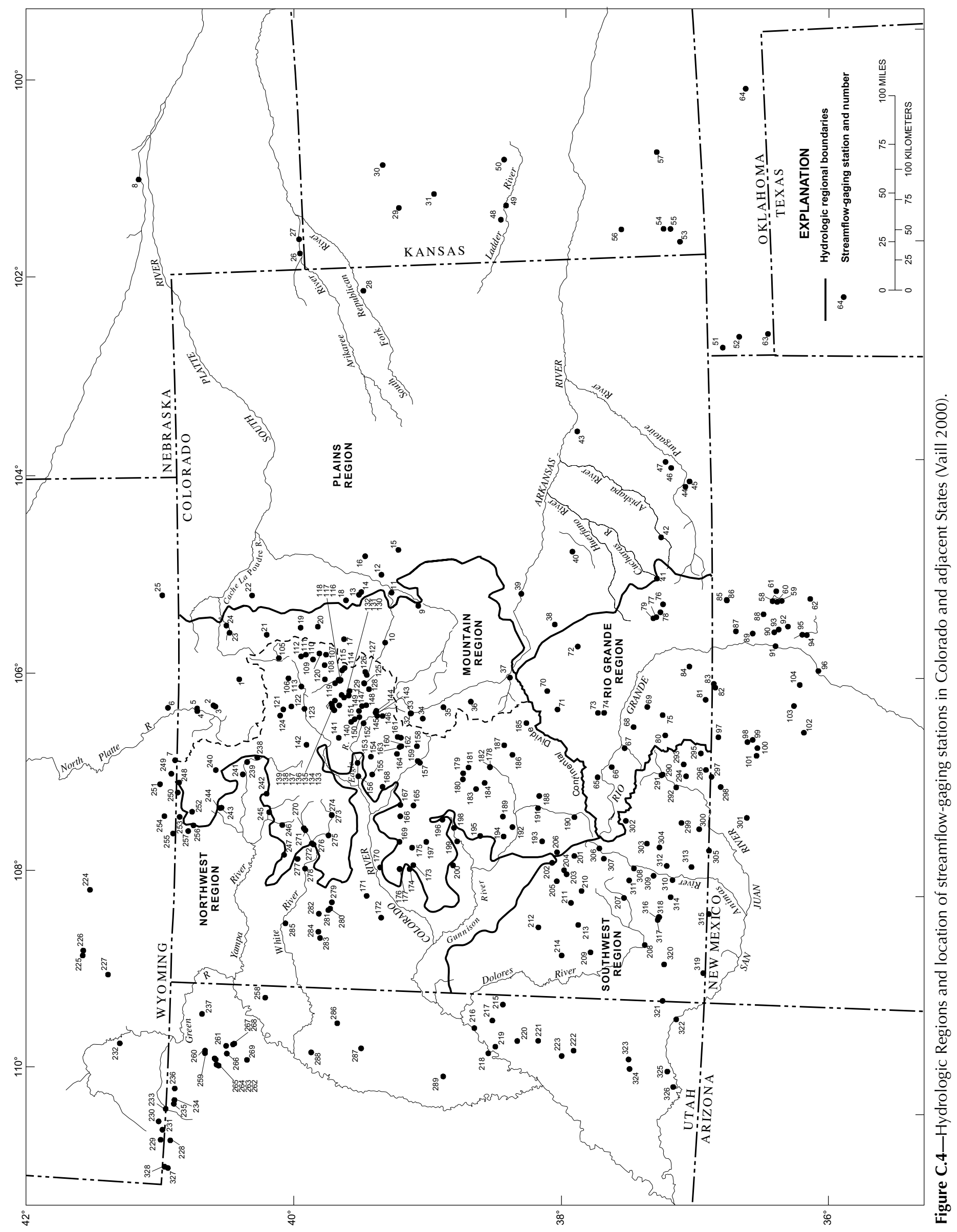




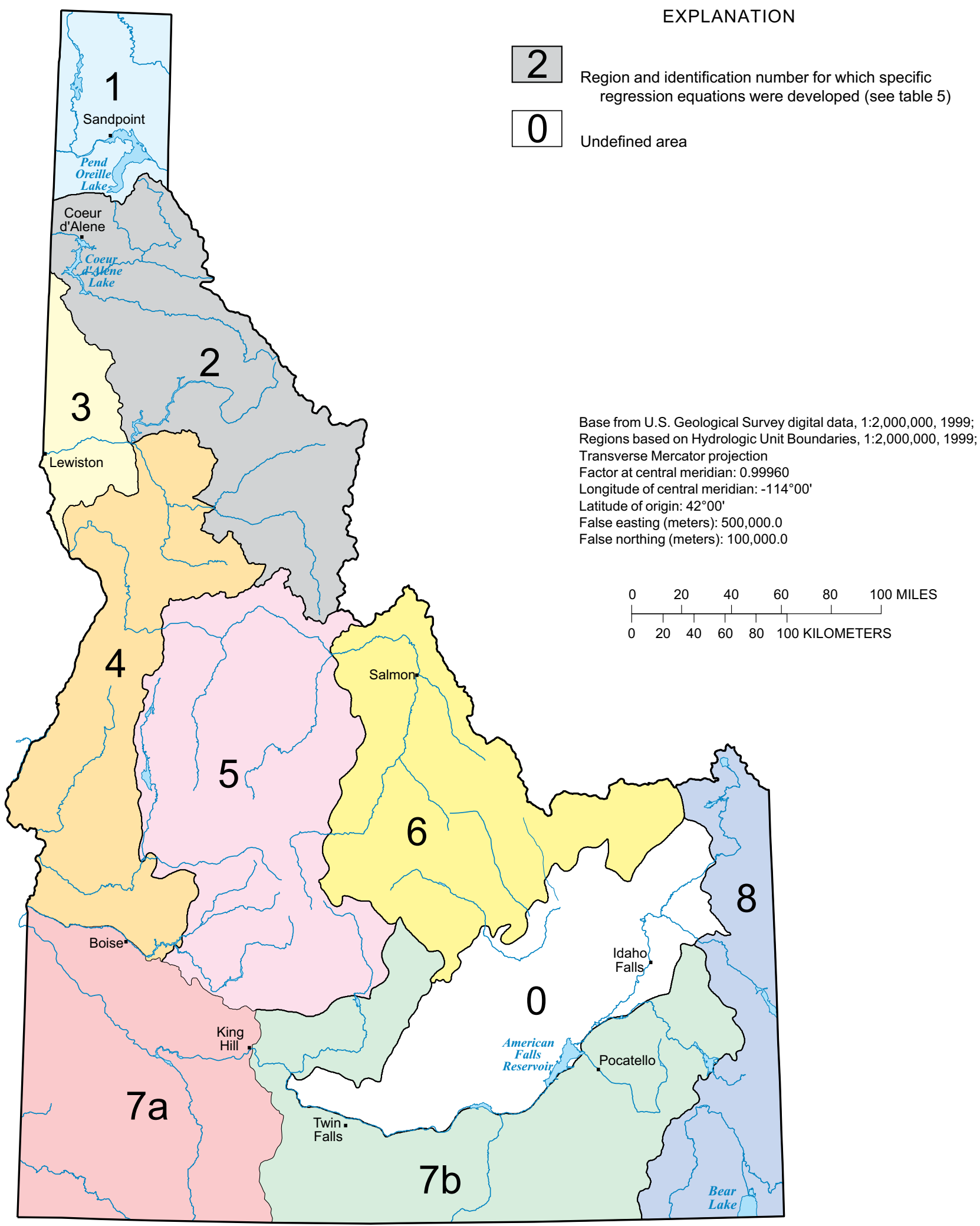

Figure C.5-Hydrologic Regions of Idaho (Berenbrock 2002). 


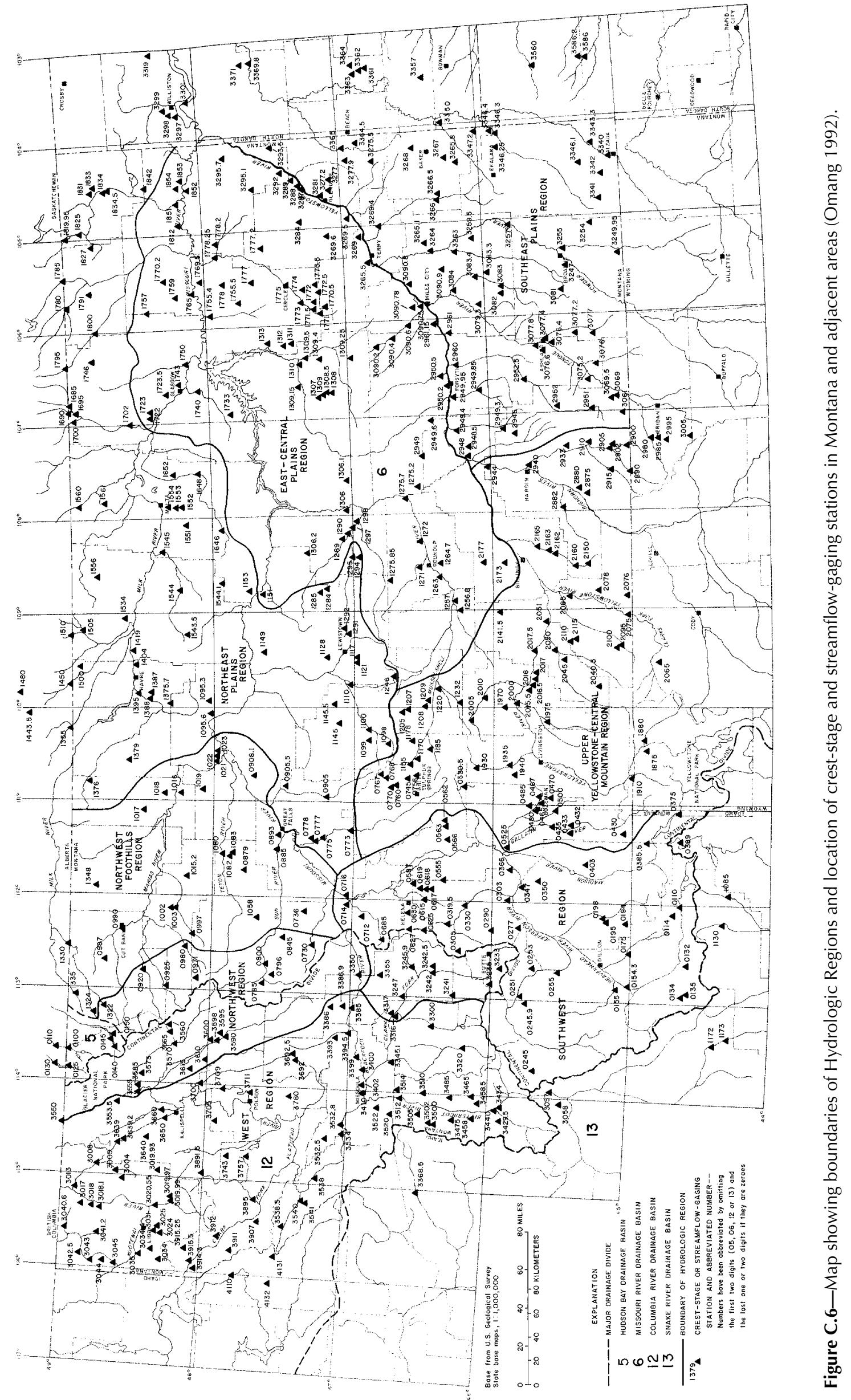




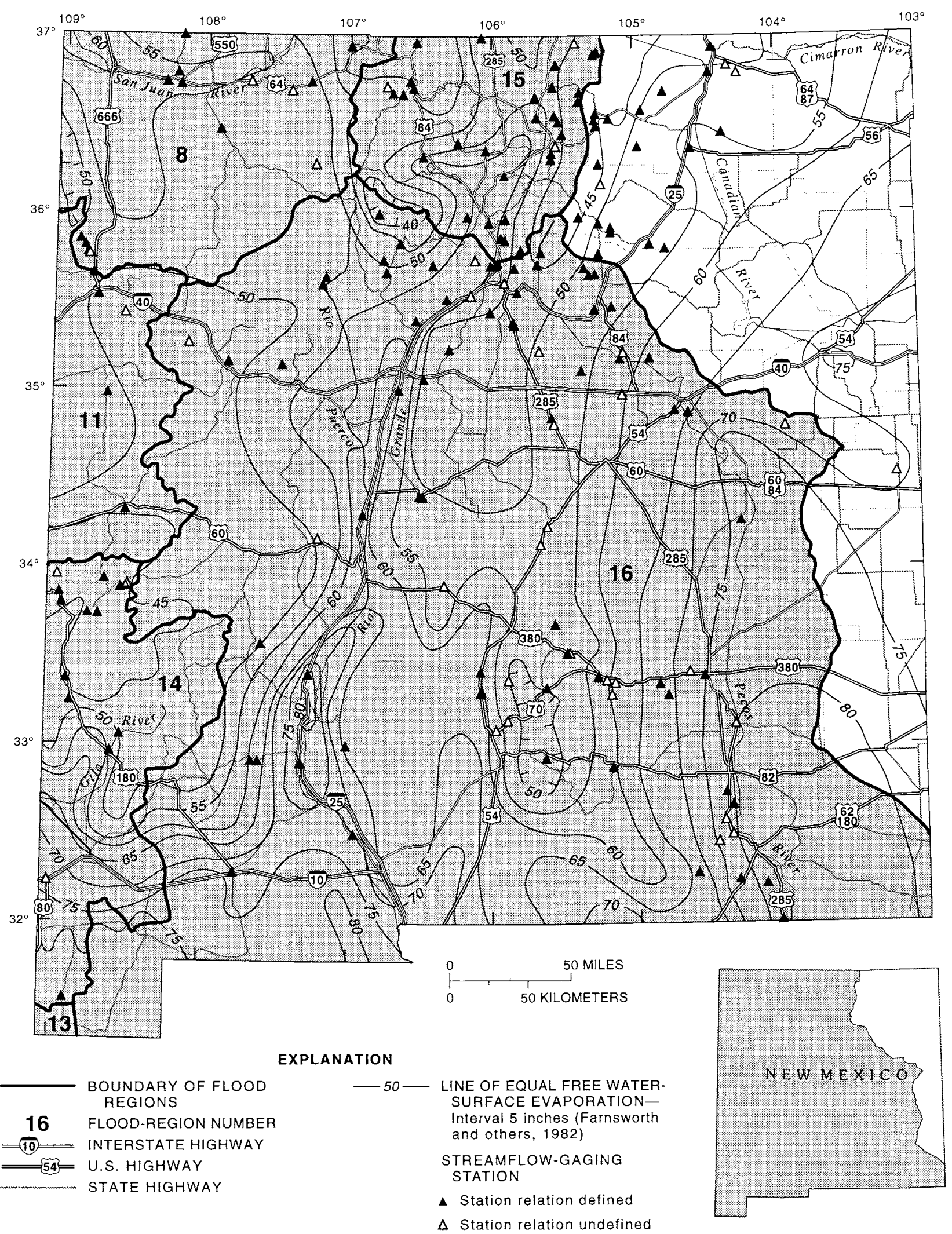

Figure C.7-Free water-surface evaporation for New Mexico (Farnsworth and others 1982; Thomas and others 1997). 


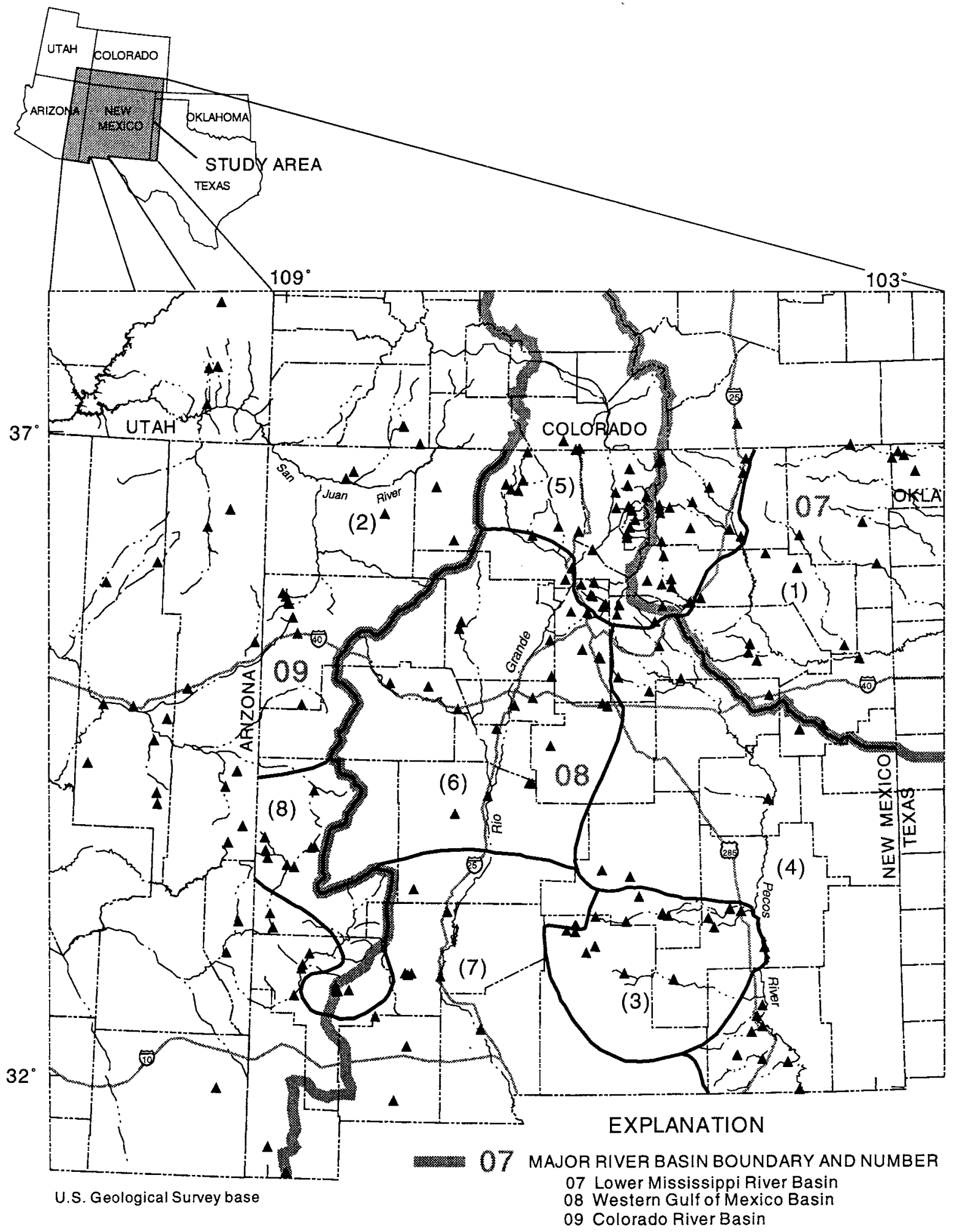

(3) PHYSIOGRAPHIC REGION BOUNDARY AND NUMBER (From Waltemeyer, 1986)

$\begin{array}{ll}\text { (1)-Northeast plains region } & \text { (5)-Northern mountain region }\end{array}$

(2)-Northwest plateau region $\quad$ (6)-Central mountain valley region

(3)-Southeast mountain region (7)-Southwest desert region

(4)-Southeast plains region $\quad$ (8)-Southwest mountain region

- GAGING STATION

Figure C.8-Hydrologic Regions of New Mexico (Waltemeyer 1996). 

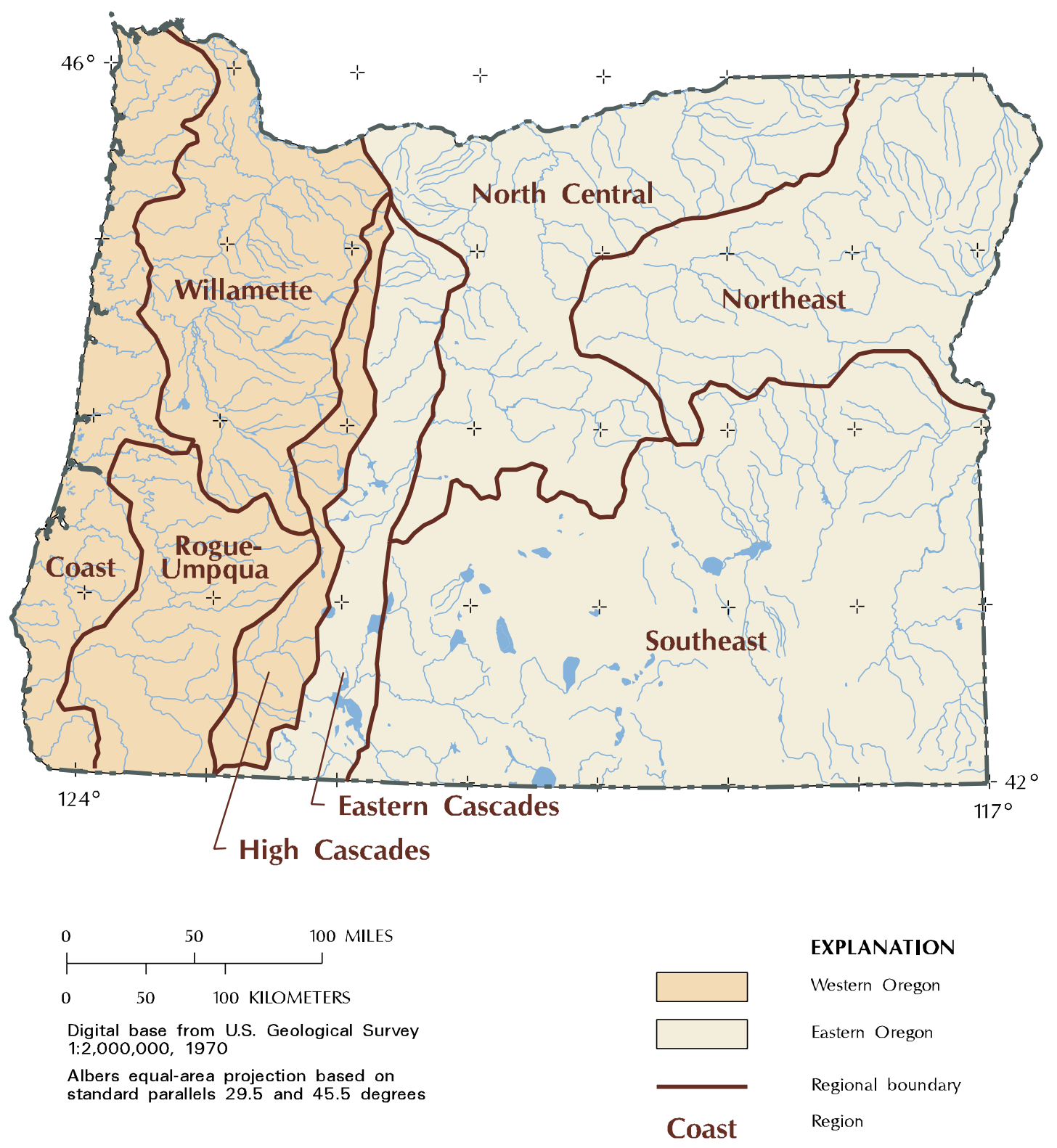

Figure C.9-Hydrologic Regions of Oregon (Jennings and others 1994). 

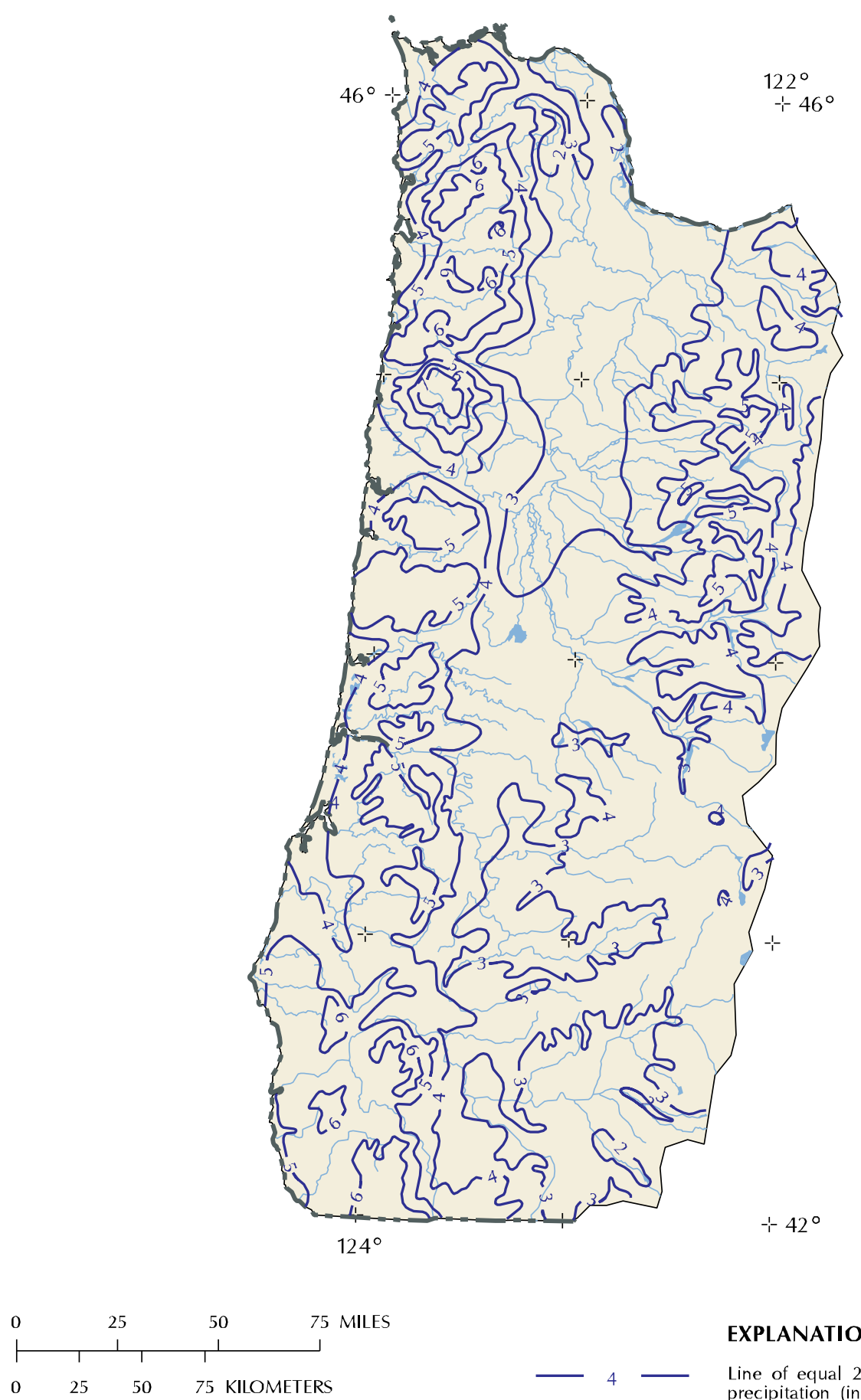

EXPLANATION

Digital base from U.S. Geological Survey 1:2,000,000, 1970

Albers equal-area projection based on standard parallels 29.5 and 45.5 degrees

Figure C.10-The 2-year, 24-hour rainfall intensities in western Oregon (Jennings and others 1994). 


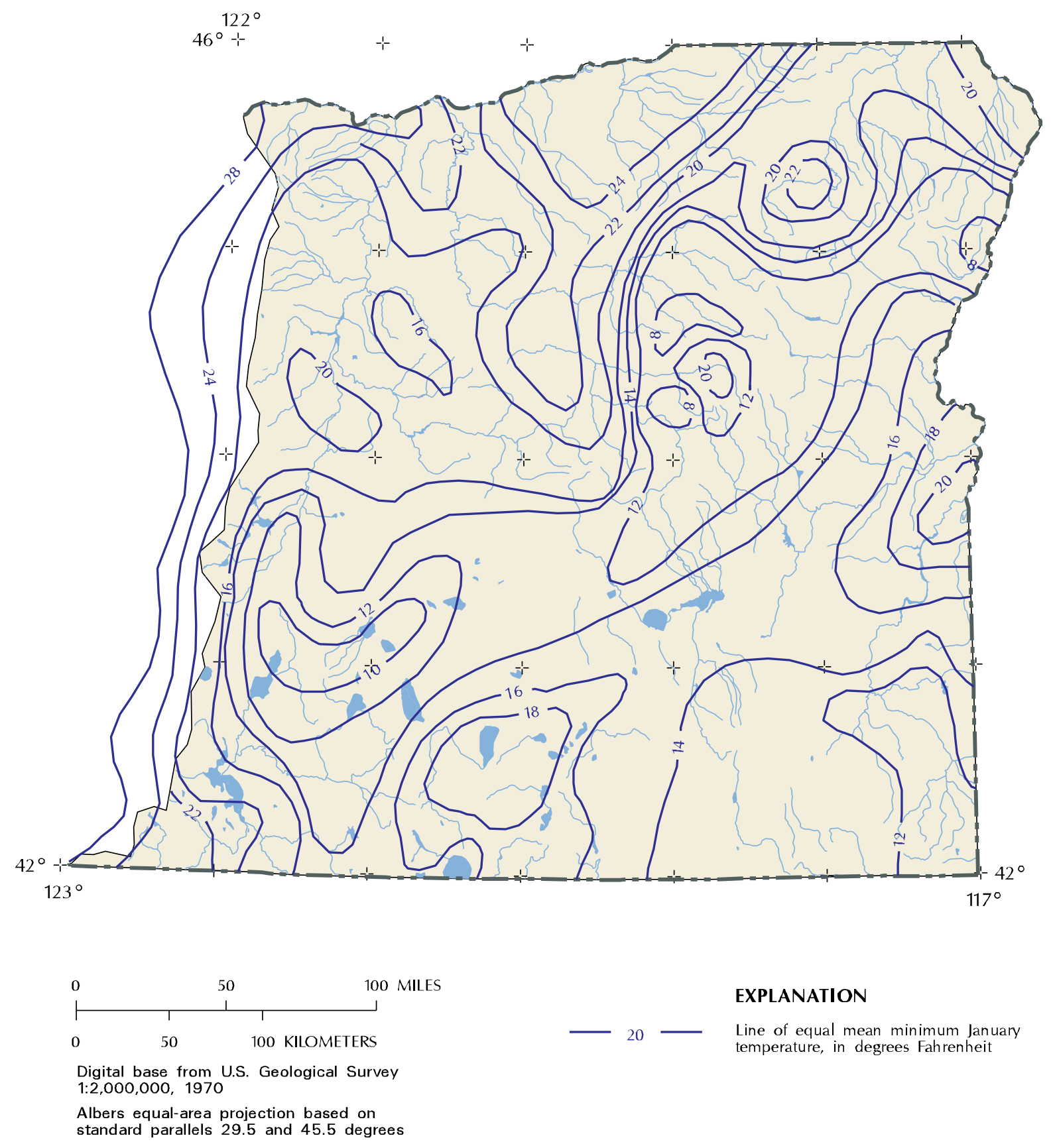

Figure C.11-Mean daily minimum January temperature in eastern Oregon (Jennings and others 1994). 


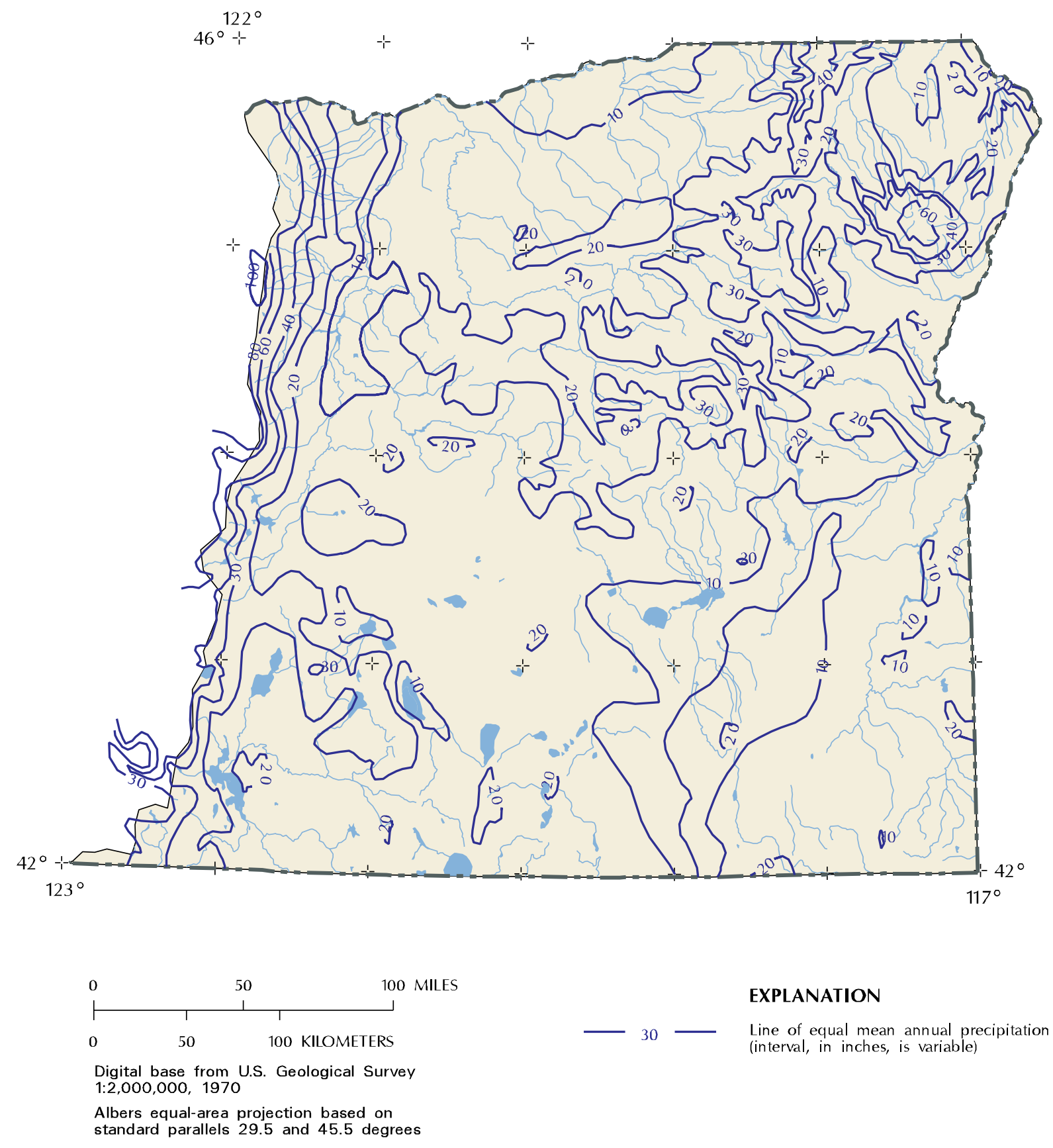

Figure C.12-Mean annual precipitation in eastern Oregon (Jennings and others 1994). 


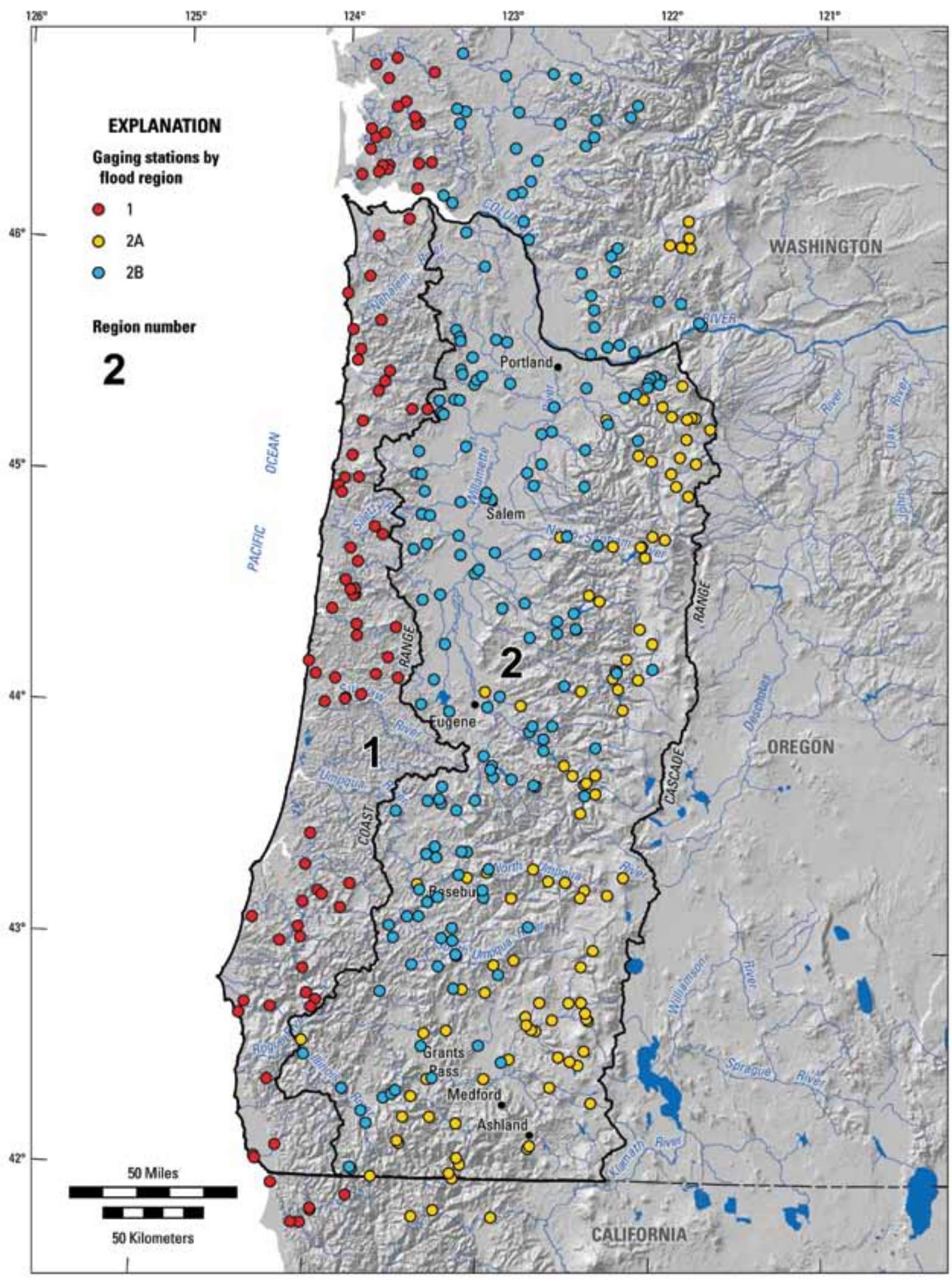

Figure C.13-Hydrologic regions of western Oregon (Cooper 2005). Regions 2A and 2B cannot be separated into discrete areas and shown together as Region 2; however, the gaging stations associated with Regions $2 \mathrm{~A}$ and $2 \mathrm{~B}$ give a rough approximation of the areal extent of each Region. 


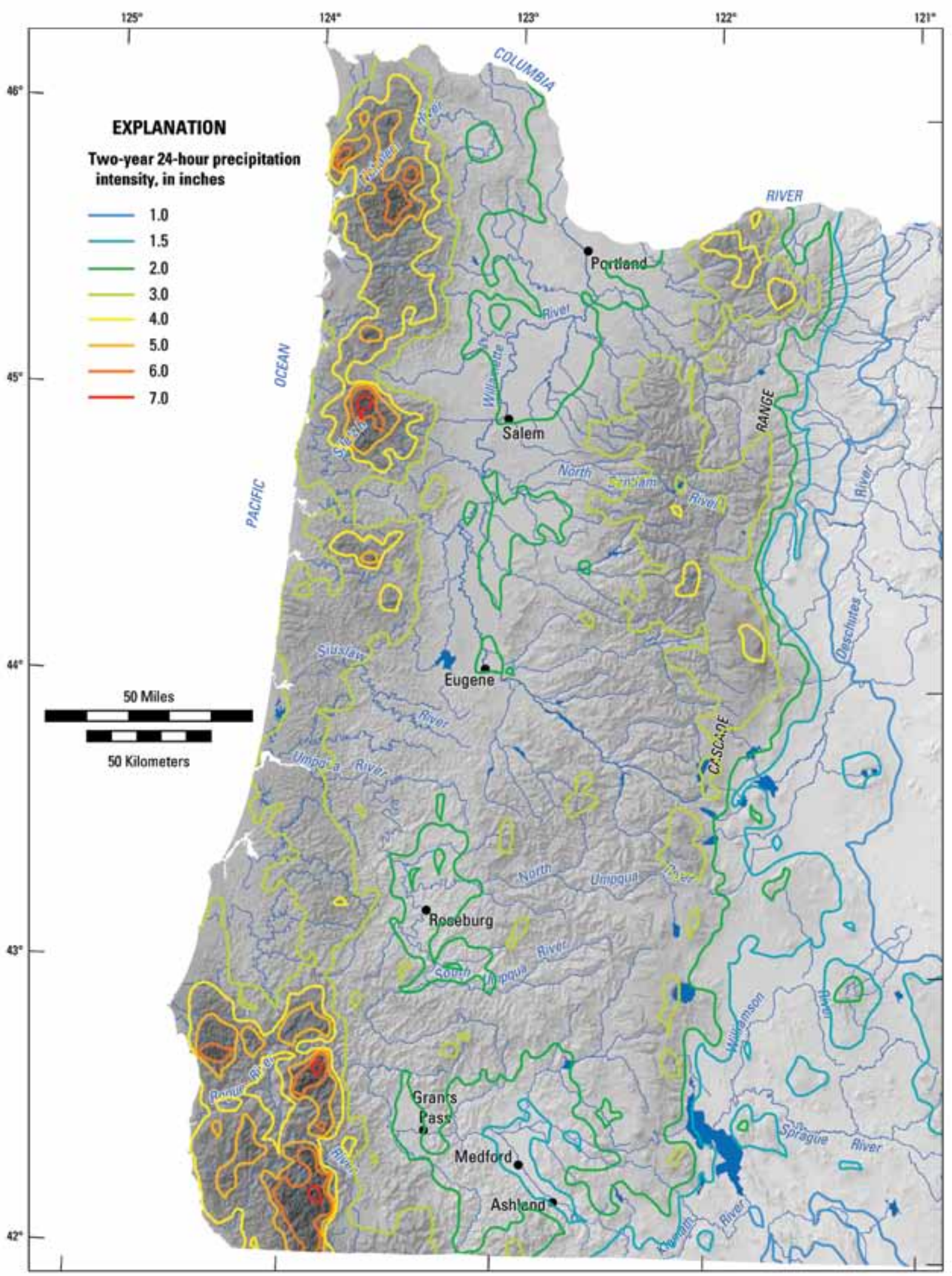

Figure C.14-The 2-year, 24-hour rainfall intensity of western Oregon (1961 to 1990; Cooper 2005). The isolines are superimposed on both a shaded relief map of elevation and the Geographic Information System grid of the 2-year, 24-hour precipitation intensities on which the isolines are based. Darker areas represent higher precipitation intensities. 


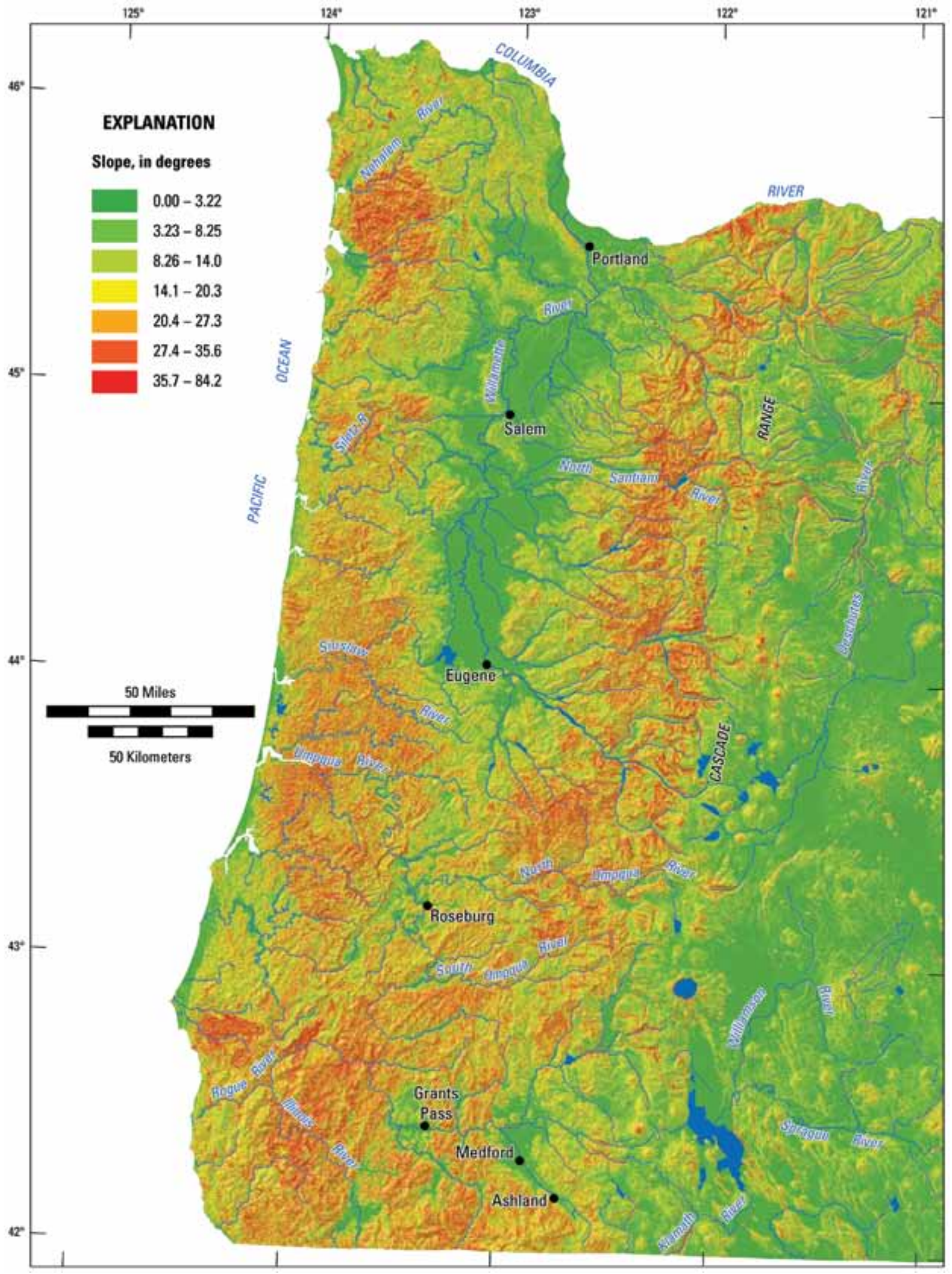

Figure C.15-Areal distribution of basin slope in western Oregon (Cooper 2005). 


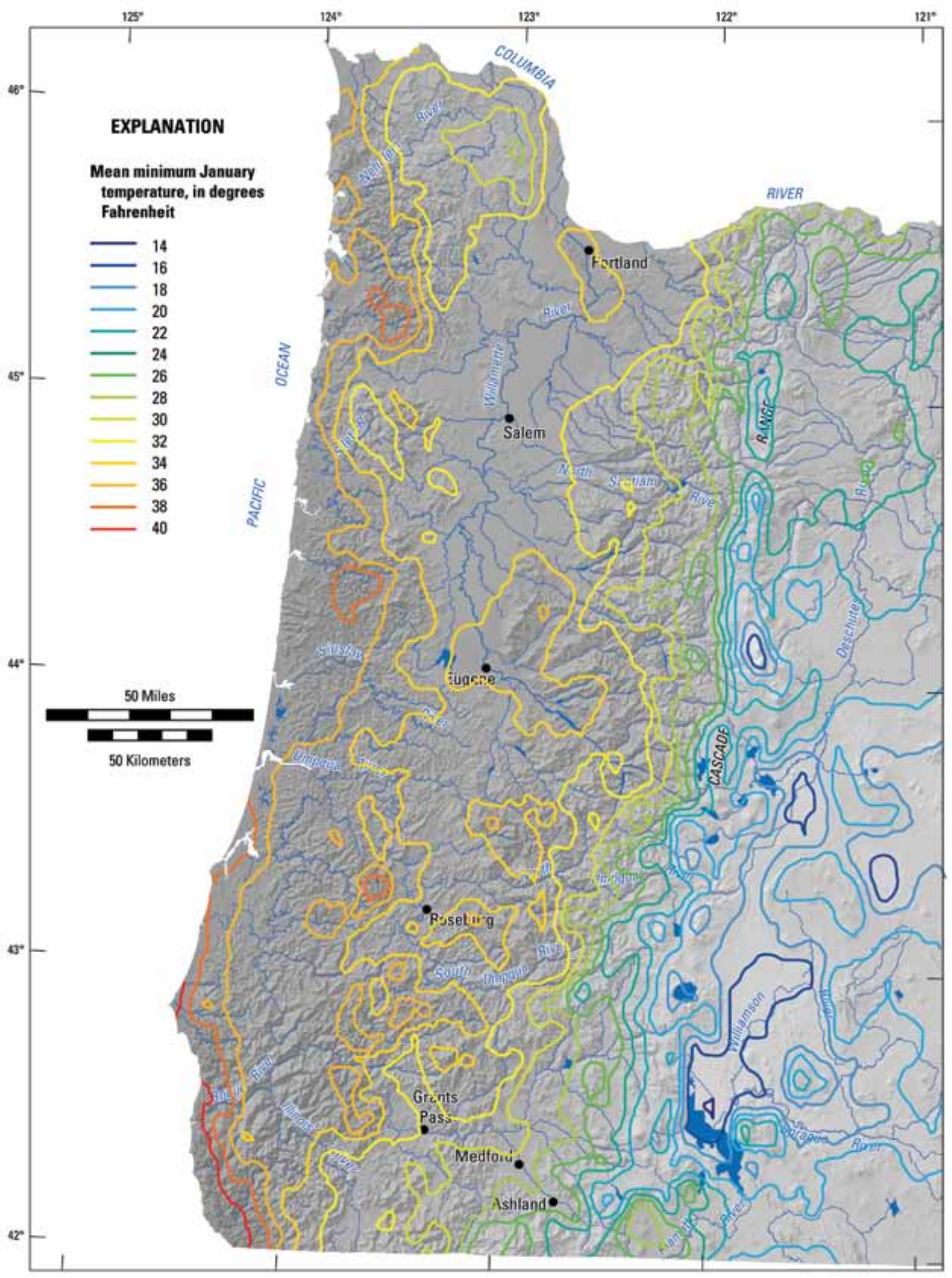

Figure C.16-Mean minimum January temperature of western Oregon (1961 to 1990; Cooper 2005). The isolines are superimposed on both a shaded relief map of elevation and the Geographic Information System grid of the mean minimum January temperatures on which the isolines are based. Darker areas represent higher temperatures. 


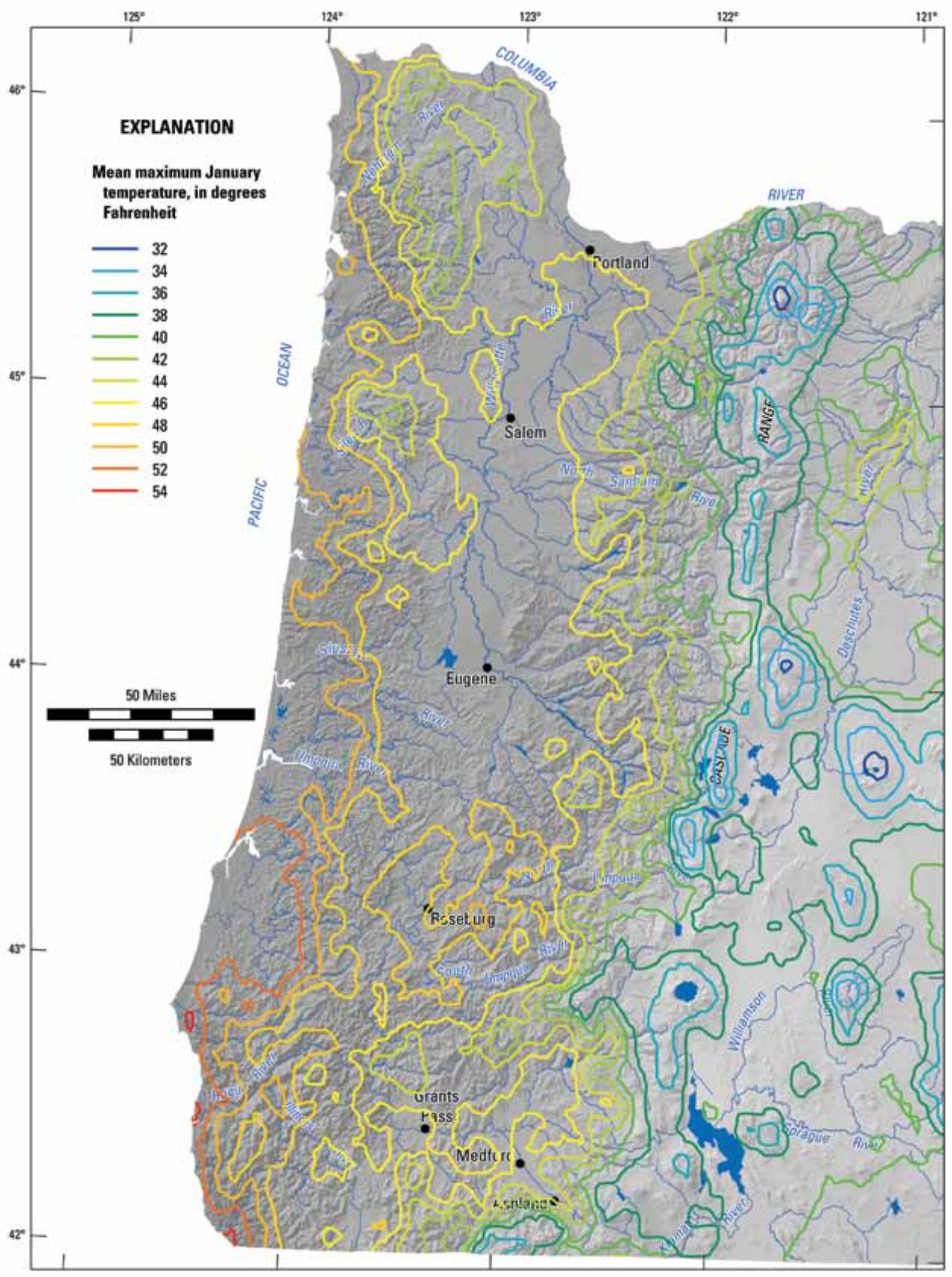

Figure C.17-Mean maximum January temperature of western Oregon (1961 to 1990; Cooper 2005). The isolines are superimposed on both a shaded relief map of elevation and the Geographic Information System grid of the mean maximum January temperatures on which the isolines are based. Darker areas represent higher temperatures. 


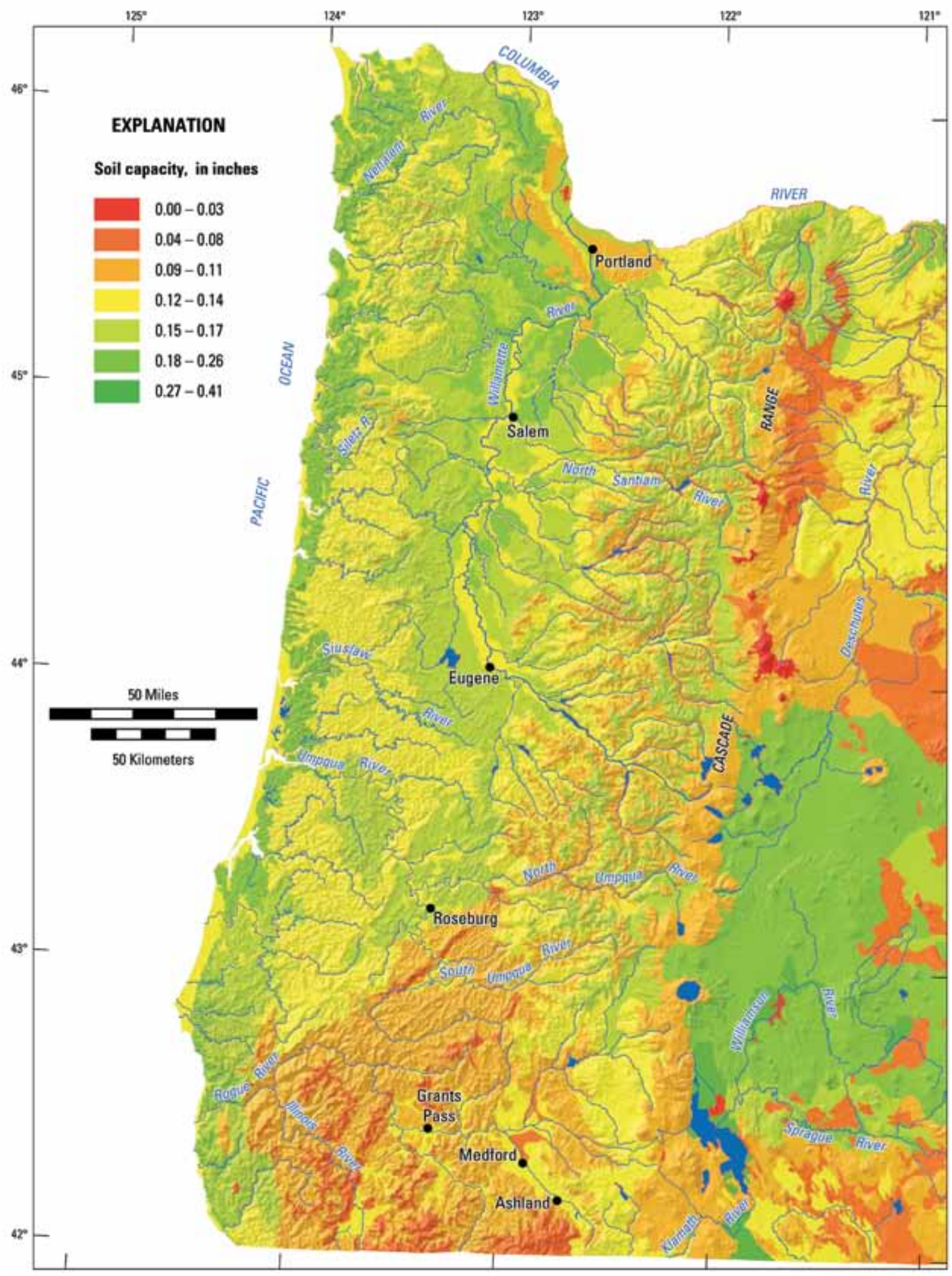

Figure C.18-Areal distribution of soil storage capacity in western Oregon (Cooper 2005). 


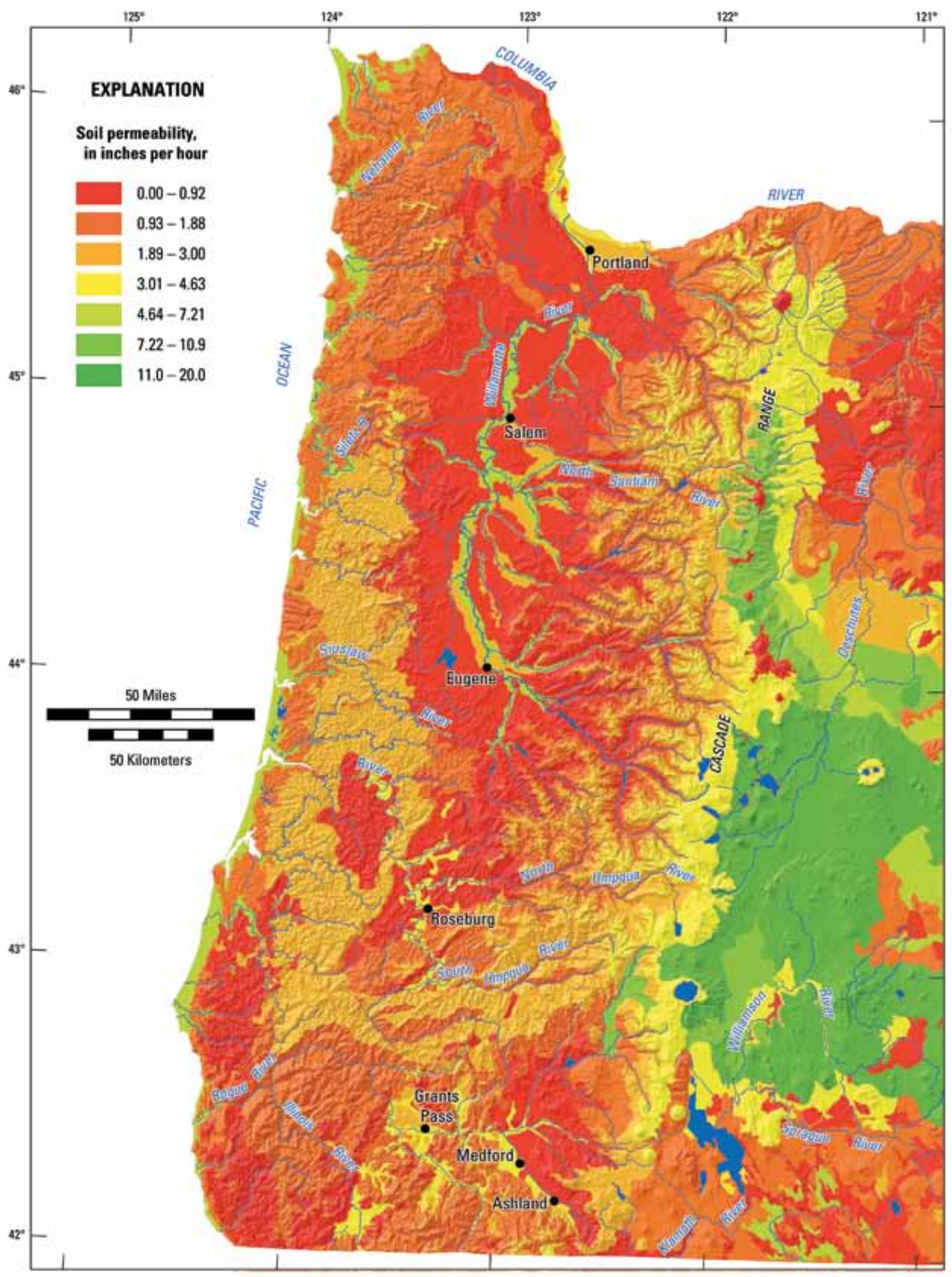

Figure C.19_Areal distribution of soil permeability in western Oregon (Cooper 2005). 


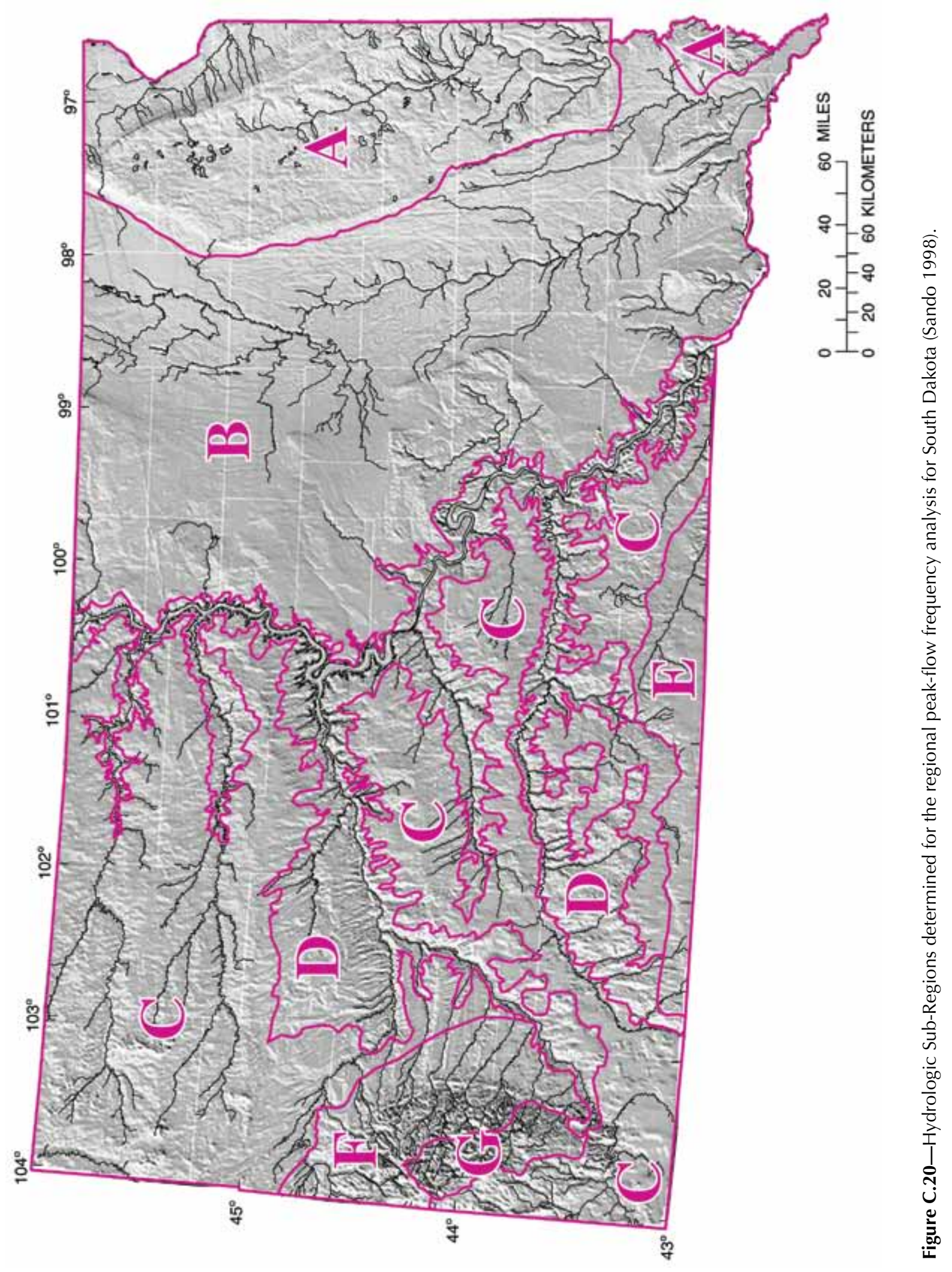




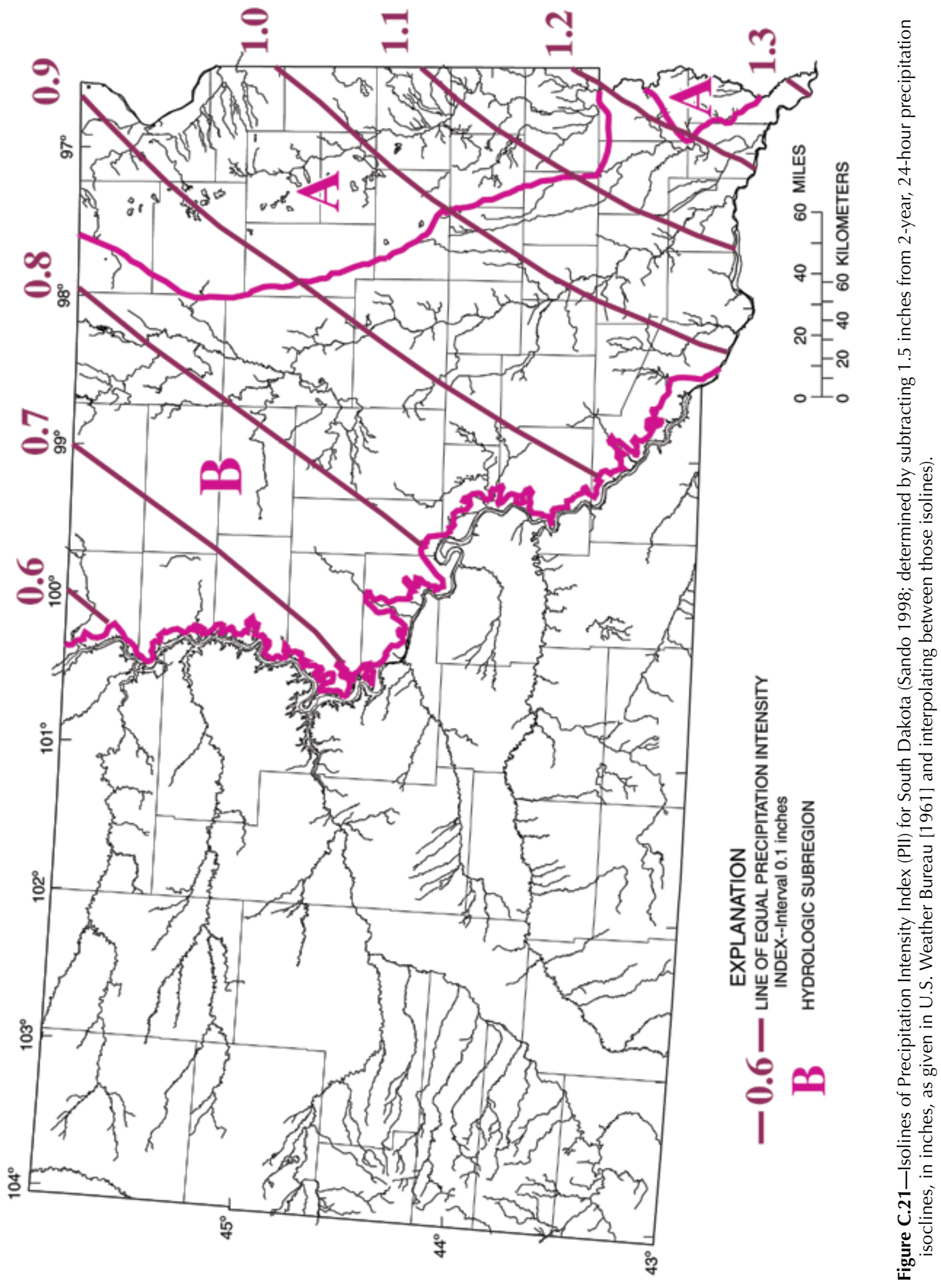




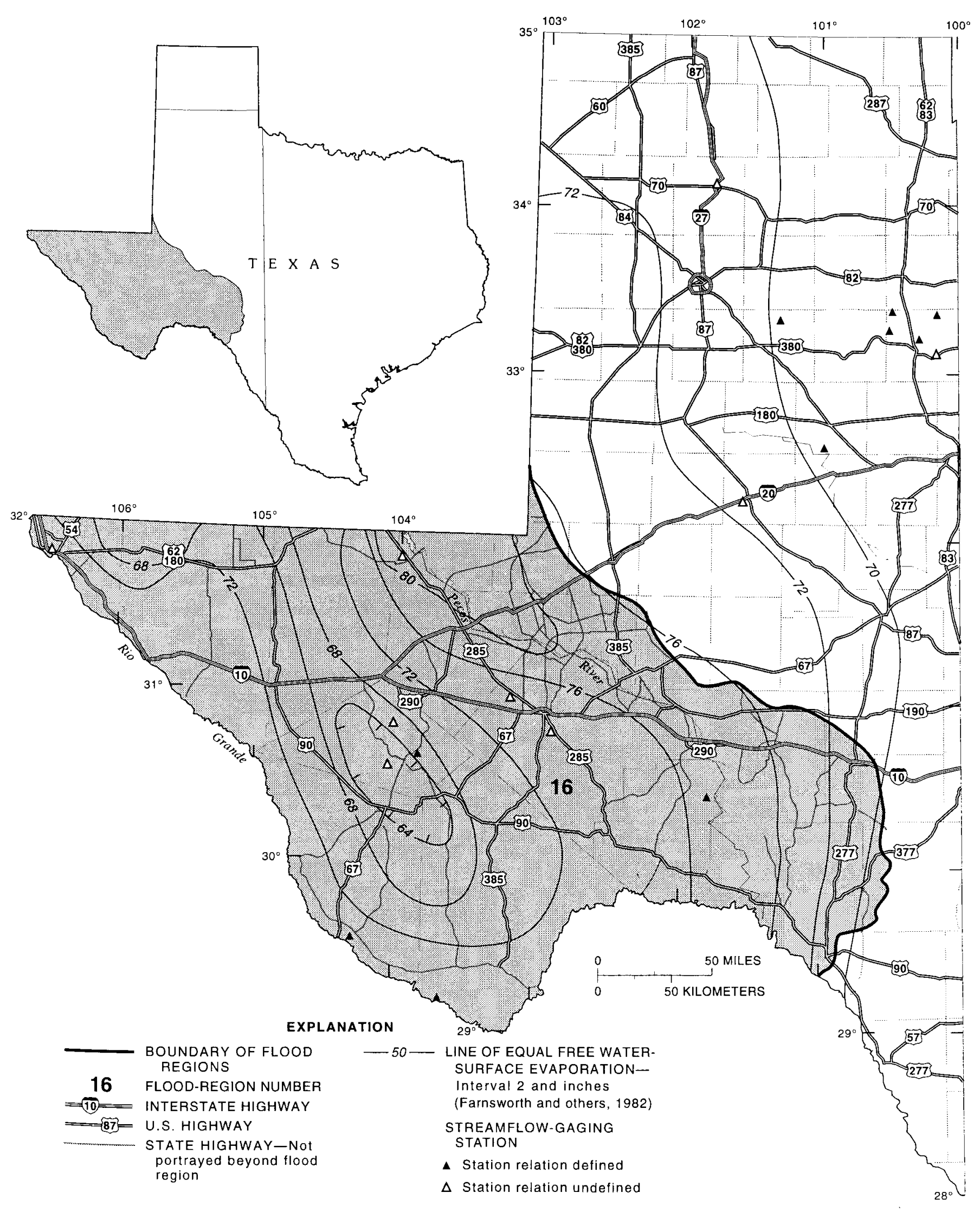

Figure C.22-Free water-surface evaporation for Texas (Farnsworth and others 1982; Thomas and others 1997). 


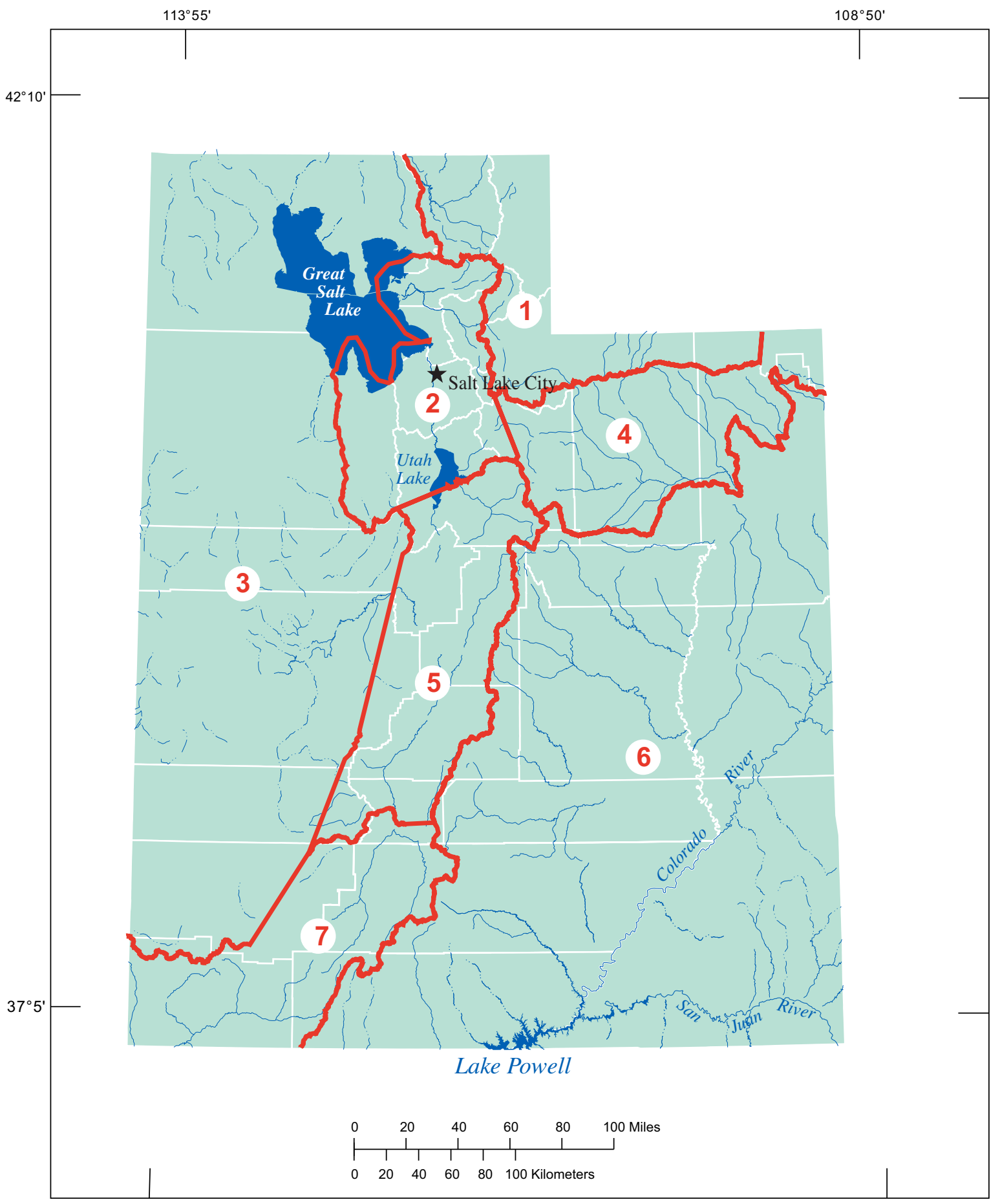

Figure C.23-Geohydrologic Regions of Utah (Kenney and others 2007). 


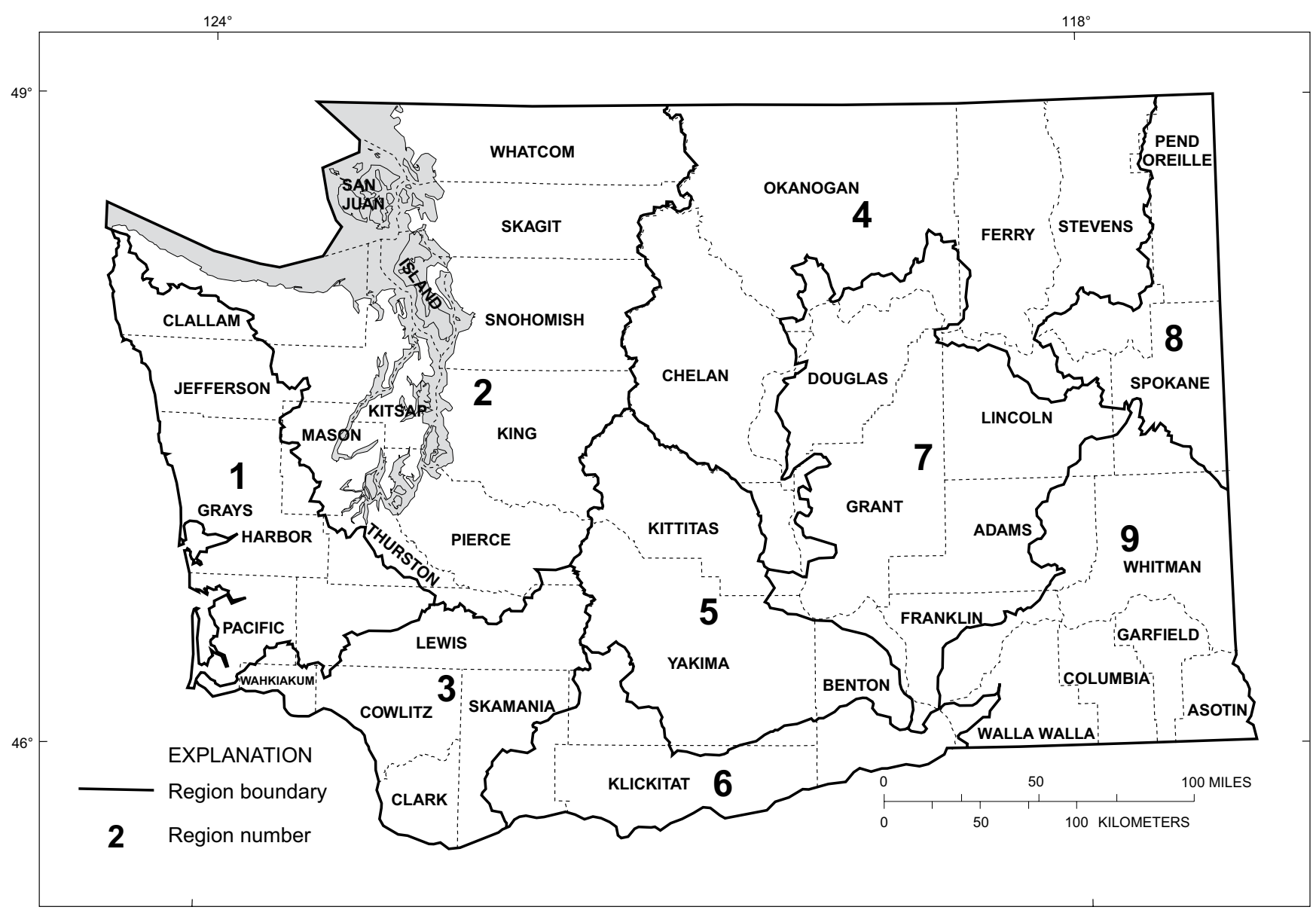

Figure C.24-Hydrologic Regions of Washington (Knowles and Sumioka 2001; Seaber and others 1987; Sumioka and others 1998). 

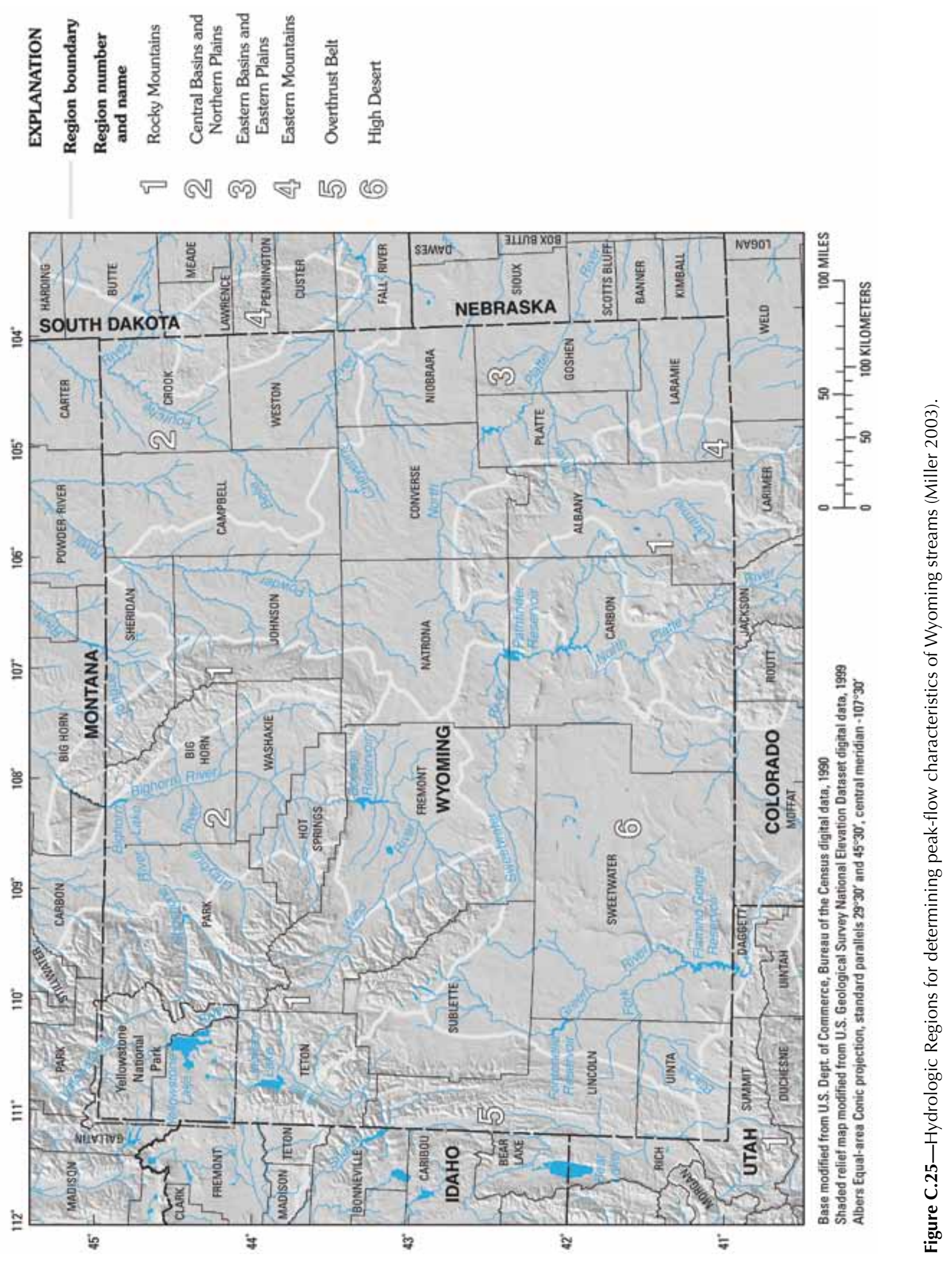


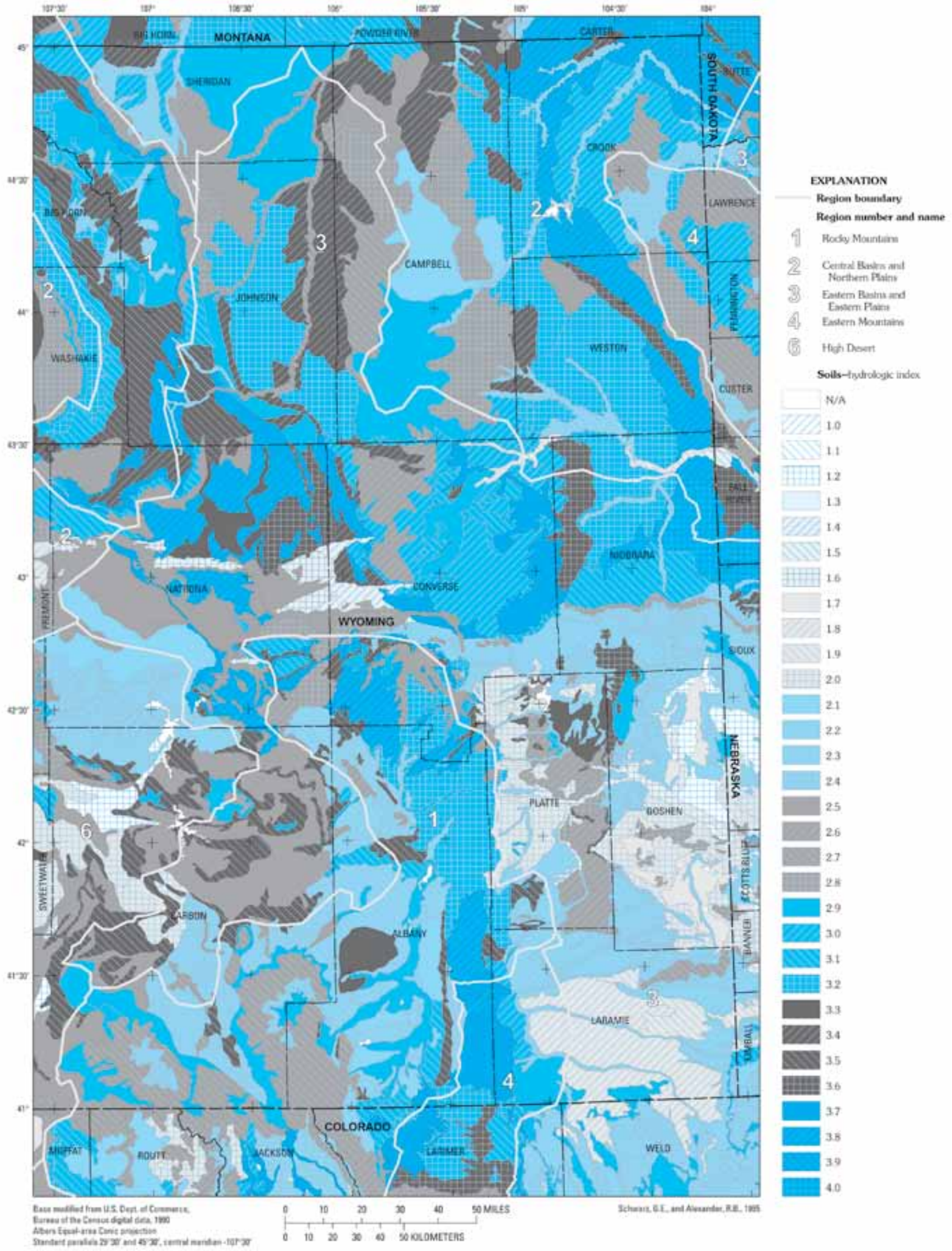

Figure C.26-Soil Hydrologic Index for Wyoming (Miller 2003). 

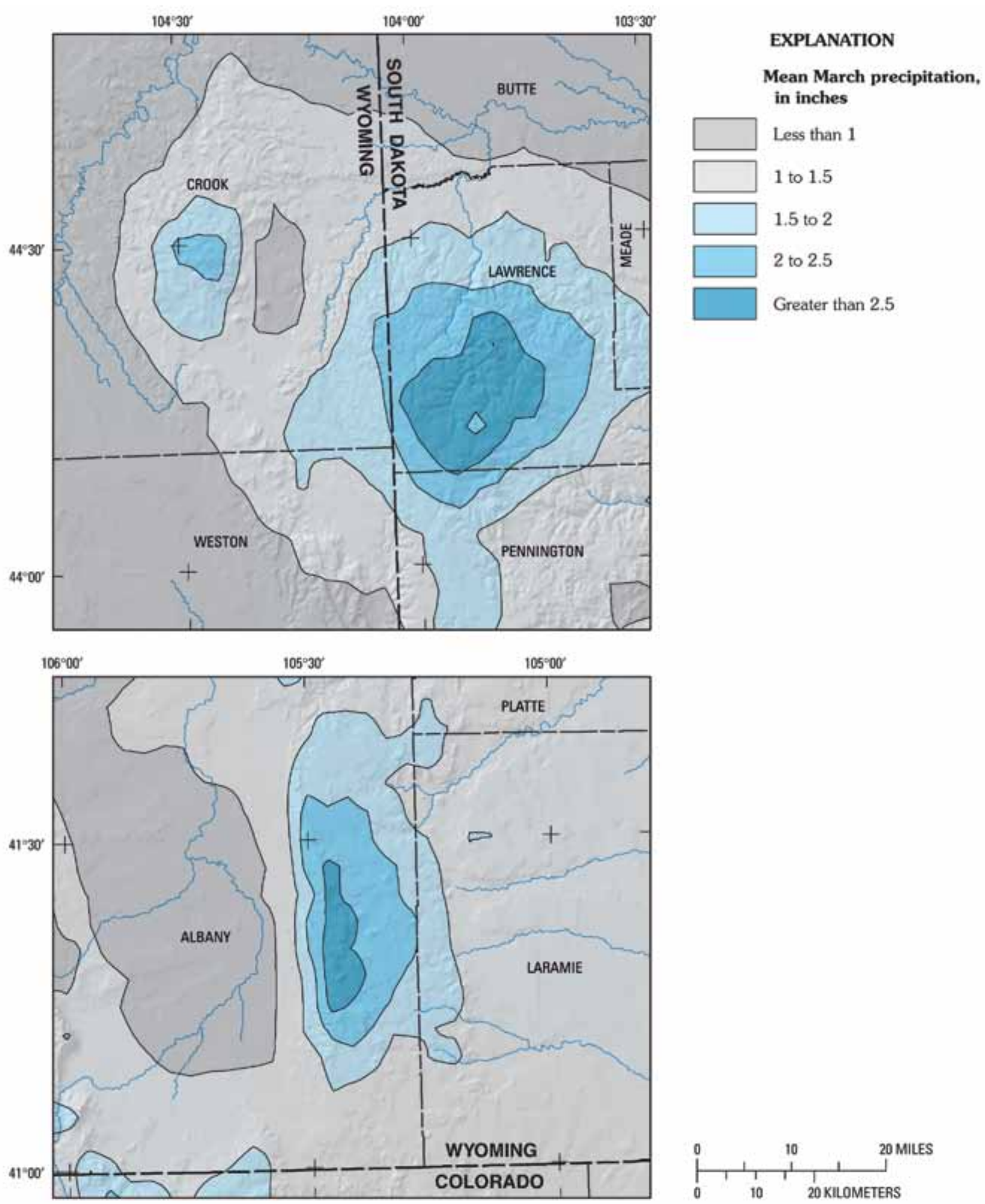

Base modified from U.S. Dept. of Commerce,

Oregon Climate Service, 19986

Bureau of the Census digital data, 1990

Shaded relief map modified from U.S. Geological

Survey National Elevation Dataset digital data, 1999

Albers Equal-area Conic projection

Standard parallels $29^{\circ} 30^{\prime}$ and $45^{\circ} 30^{\circ}$, central meridian $-107^{\circ} 30^{\circ}$

Figure C.27-Mean March precipitation, Eastern Mountains Region, Wyoming (Miller 2003). 


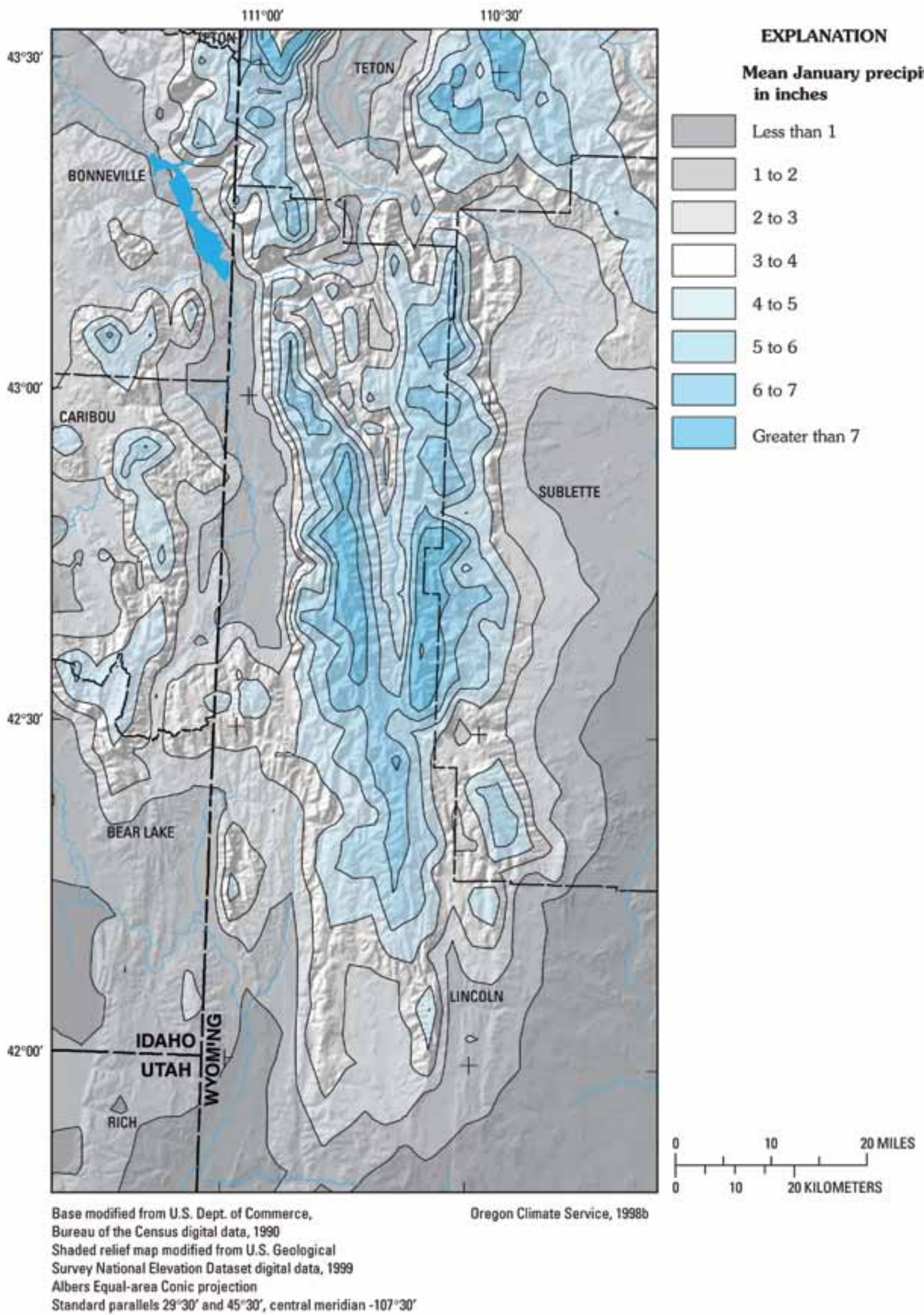

Figure C.28-Mean January precipitation, Overthrust Belt Region, Wyoming (Miller 2003). 
Table C.1-Generalized least-squares regression equations for estimating regional flood-frequency relations for the High-Elevation Region 1 (Thomas and others 1997). Data were based on 165 stations. Average number of years of systematic record is 28 .

\begin{tabular}{cccc}
\hline $\begin{array}{c}\text { Recurrence } \\
\text { interval }(\mathbf{y r})\end{array}$ & Equation $^{\mathbf{a}}$ & $\begin{array}{c}\text { Average standard } \\
\text { error of prediction (\%) }\end{array}$ & $\begin{array}{c}\text { Equivalent years } \\
\text { of record }\end{array}$ \\
\hline 2 & $Q=0.124$ AREA $^{0.845} \mathrm{PREC}^{1.44}$ & 59 & 0.16 \\
5 & $Q=0.629 \mathrm{AREA}^{0.807} \mathrm{PREC}^{1.12}$ & 52 & 0.62 \\
10 & $Q=1.43 \mathrm{AREA}^{0.786} \mathrm{PREC}^{0.958}$ & 48 & 1.34 \\
25 & $Q=3.08 \mathrm{AREA}^{0.768} \mathrm{PREC}^{0.811}$ & 46 & 2.50 \\
50 & $\mathrm{Q}=4.75 \mathrm{AREA}^{0.758} \mathrm{PREC}^{0.732}$ & 46 & 3.37 \\
100 & $Q=6.78 \mathrm{AREA}^{0.750} \mathrm{PREC}^{0.668}$ & 46 & 4.19 \\
\hline
\end{tabular}

${ }^{a}$ Equation: $Q$, peak flow, in $\mathrm{ft}^{3} \mathrm{sec}^{-1}$; AREA, drainage area, in $\mathrm{mi}^{2}$; PREC, mean annual precipitation, in inches

Table C.2-Generalized least-squares regression equations for estimating regional flood-frequency relations for the Northwest Region 2 (Thomas and others 1997). Data were based on 108 stations. Average number of years of systematic record is 26 .

\begin{tabular}{cccc}
$\begin{array}{c}\text { Recurrence } \\
\text { interval (yr) }\end{array}$ & Equation $^{\mathbf{a}}$ & $\begin{array}{c}\text { Average standard } \\
\text { error of prediction (\%) }\end{array}$ & $\begin{array}{c}\text { Equivalent years } \\
\text { of record }\end{array}$ \\
\hline 2 & $Q=13.1 \mathrm{AREA}^{0.713}$ & 72 & 0.96 \\
5 & $Q=22.4 \mathrm{AREA}^{0.723}$ & 66 & 1.80 \\
10 & $Q=55.7 \mathrm{AREA}^{0.727}\left(\mathrm{ELEV}^{0} / 1,000\right)^{-0.353}$ & 61 & 3.07 \\
25 & $Q=84.7 \mathrm{AREA}^{0.737}(\mathrm{ELEV} / 1,000)^{-0.438}$ & 61 & 4.64 \\
50 & $Q=113 \mathrm{AREA}^{0.746}(\mathrm{ELEV} / 1,000)^{-0.511}$ & 64 & 5.47 \\
100 & $Q=148 \mathrm{AREA}^{0.752}(\mathrm{ELEV} / 1,000)^{-0.584}$ & 68 & 6.05 \\
\hline
\end{tabular}

a Equation: $Q$, peak flow, in $\mathrm{ft}^{3} \mathrm{sec}^{-1} ; \mathrm{AREA}$, drainage area, in $\mathrm{mi}^{2}$; ELEV, mean basin elevation, in $\mathrm{ft}$

Table C.3-Generalized least-squares regression equations for estimating regional flood-frequency relations for the South-Central Idaho Region 3 (Thomas and others 1997). Data were based on 35 stations. Average number of years of systematic record is 32 .

\begin{tabular}{cccc}
$\begin{array}{c}\text { Recurrence } \\
\text { interval }(\mathbf{y r})\end{array}$ & Equation $^{\mathbf{a}}$ & $\begin{array}{c}\text { Average standard } \\
\text { error of prediction (\%) }\end{array}$ & $\begin{array}{c}\text { Equivalent years } \\
\text { of record }\end{array}$ \\
\hline 2 & $Q=0.444 \mathrm{AREA}^{0.649} \mathrm{PREC}^{1.15}$ & 86 & 0.29 \\
5 & $Q=1.21 \mathrm{AREA}^{0.639} \mathrm{PREC}^{0.995}$ & 83 & 0.49 \\
10 & $Q=1.99 \mathrm{AREA}^{0.633} \mathrm{PREC}^{0.924}$ & 80 & 0.77 \\
25 & $Q=3.37 \mathrm{AREA}^{0.627} \mathrm{PREC}^{0.849}$ & 78 & 1.23 \\
50 & $Q=4.70 \mathrm{AREA}^{0.625} \mathrm{PREC}^{0.802}$ & 77 & 1.57 \\
100 & $Q=6.42 \mathrm{AREA}^{0.621} \mathrm{PREC}^{0.757}$ & 78 & 1.92 \\
\hline
\end{tabular}

${ }^{a}$ Equation: $Q$, peak flow, in $\mathrm{ft}^{3} \mathrm{sec}^{-1}$; AREA, drainage area, in $\mathrm{mi}^{2}$; PREC, mean annual precipitation, in inches

Table C.4-Generalized least-squares regression equations for estimating regional flood-frequency relations for the Northeast Region 4 (Thomas and others 1997). Data were based on 108 stations. Average number of years of systematic record is 28 .

\begin{tabular}{lccc}
\hline $\begin{array}{l}\text { Recurrence } \\
\text { interval }(\mathbf{y r})\end{array}$ & Equation $^{\mathbf{a}}$ & $\begin{array}{c}\text { Average standard } \\
\text { error of prediction (\%) }\end{array}$ & $\begin{array}{c}\text { Equivalent years } \\
\text { of record }\end{array}$ \\
\hline 2 & $Q=0.0405 \mathrm{AREA}^{0.701}(\mathrm{ELEV} / 1,000)^{2.91}$ & 64 & 0.39 \\
5 & $Q=0.408 \mathrm{AREA}^{0.683}(\mathrm{ELEV} / 1,000)^{2.05}$ & 57 & 0.95 \\
10 & $\mathrm{Q}=1.26 \mathrm{AREA}^{0.674}(\mathrm{ELEV} / 1,000)^{1.64}$ & 53 & 1.76 \\
25 & $Q=3.74 \mathrm{AREA}^{0.667}(\mathrm{ELEV} / 1,000)^{1.24}$ & 51 & 3.02 \\
50 & $Q=7.04 \mathrm{AREA}^{0.664}(\mathrm{ELEV} / 1,000)^{1.02}$ & 52 & 3.89 \\
100 & $Q=11.8 \mathrm{AREA}^{0.662}(\mathrm{ELEV} / 1,000)^{0.835}$ & 53 & 4.65 \\
\hline
\end{tabular}

\footnotetext{
${ }^{a}$ Equation: $Q$, peak flow, in $\mathrm{ft}^{3} \mathrm{sec}^{-1}$; AREA, drainage area, in $\mathrm{mi}^{2}$; ELEV, mean basin elevation, in $\mathrm{ft}$
} 
Table C.5-Generalized least-squares regression equations for estimating regional flood-frequency relations for the Eastern Sierras Region 5 (Thomas and others 1997). Data were based on 37 stations. Average number of years of systematic record is 31 .

\begin{tabular}{clcc}
\hline $\begin{array}{c}\text { Recurrence } \\
\text { interval }(\mathbf{y r})\end{array}$ & \multicolumn{1}{c}{ Equation $^{\mathbf{a}}$} & $\begin{array}{c}\text { Average standard } \\
\text { error of prediction (\%) }\end{array}$ & $\begin{array}{c}\text { Equivalent years } \\
\text { of record }\end{array}$ \\
\hline & $Q=0.0333 \mathrm{AREA}^{0.853}(\mathrm{ELEV} / 1,000)^{2.68}[(\mathrm{LAT}-28) / 10]^{4.1}$ & 135 & 0.21 \\
5 & $Q=2.42 \mathrm{AREA}^{0.823}\left(\mathrm{ELEV}^{4} / 1,000\right)^{1.01}[(\mathrm{LAT}-28) / 10]^{4.1}$ & 101 & 0.73 \\
10 & $Q=28.0 \mathrm{AREA}^{0.826}[(\mathrm{LAT}-28) / 10]^{4.3}$ & 84 & 1.69 \\
25 & $Q=426 \mathrm{AREA}^{0.812}(\mathrm{ELEV} / 1,000)^{-1.10}[(\mathrm{LAT}-28) / 10]^{4.3}$ & 87 & 2.62 \\
50 & $Q=2,030 \mathrm{AREA}^{0.798}(\mathrm{ELEV} / 1,000)^{-1.71}[(\mathrm{LAT}-28) / 10]^{4.4}$ & 91 & 3.26 \\
100 & $Q=7,000 \mathrm{AREA}^{0.782}\left(\mathrm{ELEV}^{4} / 1,000\right)^{-2.18}[(\mathrm{LAT}-28) / 10]^{4.6}$ & 95 & 3.80 \\
\hline
\end{tabular}

${ }^{a}$ Equation: $Q$, peak flow, in $\mathrm{ft}^{3} \mathrm{sec}^{-1}$; AREA, drainage area, in $\mathrm{mi}^{2}$; ELEV, mean basin elevation, in $\mathrm{ft}$; LAT, latitude of site, in decimal degrees

Table C.6-Hybrid equations for estimating regional flood-frequency relations for the Northern Great Basin Region 6 (Thomas and others 1997). Data were based on 80 stations. Average number of years of systematic record is 19.

\section{Recurrence interval (yr)}

\section{Estimated average standard error of regression ${ }^{b}$ (log units)}

Equivalent years of record

\begin{tabular}{|c|c|c|c|}
\hline 2 & $Q=0$ & $-^{c}$ & - \\
\hline 5 & $Q=32 \operatorname{AREA}^{0.80}(E L E V / 1,000)^{-0.66}$ & 1.47 & 0.233 \\
\hline 10 & $Q=590 \operatorname{AREA}^{0.62}(\mathrm{ELEV} / 1,000)^{-1.6}$ & 1.12 & 0.748 \\
\hline 25 & $Q=3,200$ AREA $^{0.62}\left(E_{L E V} / 1,000\right)^{-2.1}$ & 0.796 & 2.52 \\
\hline 50 & $Q=5,300$ AREA $^{0.64}\left(E_{L E V} / 1,000\right)^{-2.1}$ & 1.10 & 1.75 \\
\hline 100 & $Q=20,000$ AREA $^{0.51}(E L E V / 1,000)^{-2.3}$ & 1.84 & 0.794 \\
\hline
\end{tabular}

a Equation: $Q$, peak flow, in $\mathrm{ft}^{3} \mathrm{sec}^{-1}$; AREA, drainage area, in $\mathrm{mi}^{2}$; ELEV, mean basin elevation, in $\mathrm{ft}$

${ }^{b}$ Estimated average standard error of regression for the hybrid method includes much of the within-station residual variance and therefore is not comparable to standard error of estimate from an ordinary least-squares regression.

${ }^{\mathrm{c}}$ No data

Table C.7-Generalized least-squares regression equations for estimating regional flood-frequency relations for the South-Central Utah Region 7 (Thomas and others 1997). Data were based on 28 stations. Average number of years of systematic record is 23 .

\begin{tabular}{cccc}
$\begin{array}{c}\text { Recurrence } \\
\text { interval (yr) }\end{array}$ & \multicolumn{1}{c}{ Equation $^{\mathbf{a}}$} & $\begin{array}{c}\text { Average standard } \\
\text { error of prediction (\%) }\end{array}$ & $\begin{array}{c}\text { Equivalent years } \\
\text { of record }\end{array}$ \\
\hline 2 & $Q=0.0150 \mathrm{AREA}^{0.697}(\mathrm{ELEV} / 1,000)^{-3.16}$ & 56 & 0.25 \\
5 & $Q=0.306 \mathrm{AREA}^{0.590}(\mathrm{ELEV} / 1,000)^{-2.22}$ & 45 & 1.56 \\
10 & $Q=1.25 \mathrm{AREA}^{0.526}(\mathrm{ELEV} / 1,000)^{-1.83}$ & 45 & 3.07 \\
25 & $Q=122 \mathrm{AREA}^{0.440}$ & 49 & 4.60 \\
50 & $Q=183 \mathrm{AREA}^{0.390}$ & 53 & 5.27 \\
100 & $Q=264 \mathrm{AREA}^{0.344}$ & 59 & 5.68 \\
\hline
\end{tabular}

${ }^{a}$ Equation: $Q$, peak flow, in $\mathrm{ft}^{3} \mathrm{sec}^{-1}$; AREA, drainage area, in $\mathrm{mi}^{2}$; ELEV, mean basin elevation, in $\mathrm{ft}$ 
Table C.8-Generalized least-squares regression equations for estimating regional flood-frequency relations for the Four Corners Region 8 (Thomas and others 1997). Data were based on 108 stations. Average number of years of systematic record is 27.

\begin{tabular}{clcc}
$\begin{array}{c}\text { Recurrence } \\
\text { interval }(\mathbf{y r})\end{array}$ & \multicolumn{1}{c}{ Equation $^{\mathbf{a}}$} & $\begin{array}{c}\text { Average standard error } \\
\text { of prediction (\%) }\end{array}$ & $\begin{array}{c}\text { Equivalent years } \\
\text { of record }\end{array}$ \\
\hline 2 & $Q=598 \mathrm{AREA}^{0.501}(\mathrm{ELEV} / 1,000)^{-1.02}$ & 72 & 0.37 \\
5 & $Q=2,620 \mathrm{AREA}^{0.449}(\mathrm{ELEV} / 1,000)^{-1.28}$ & 62 & 1.35 \\
10 & $Q=5,310 \mathrm{AREA}^{0.425}(\mathrm{ELEV} / 1,000)^{-1.40}$ & 57 & 2.88 \\
25 & $Q=10,500 \mathrm{AREA}^{0.403}(\mathrm{ELEV} / 1,000)^{-1.49}$ & 54 & 5.45 \\
50 & $Q=16,000 \mathrm{AREA}^{0.390}(\mathrm{ELEV} / 1,000)^{-1.54}$ & 53 & 7.45 \\
100 & $Q=23,300 \mathrm{AREA}^{0.377}(\mathrm{ELEV} / 1,000)^{-1.59}$ & 53 & 9.28 \\
\hline
\end{tabular}

${ }^{a}$ Equation: $Q$, peak flow, in $\mathrm{ft}^{3} \mathrm{sec}^{-1}$; AREA, drainage area, in $\mathrm{mi}^{2}$; ELEV, mean basin elevation, in $\mathrm{ft}$

Table C.9-Generalized least-squares regression equations for estimating regional flood-frequency relations for the Western Colorado Region 9 (Thomas and others 1997). Data were based on 43 stations. Average number of years of systematic record is 28 .

\begin{tabular}{clcc}
$\begin{array}{c}\text { Recurrence } \\
\text { interval }(\mathbf{y r})\end{array}$ & \multicolumn{1}{c}{ Equation $^{\mathbf{a}}$} & $\begin{array}{c}\text { Average standard error } \\
\text { of prediction (\%) }\end{array}$ & $\begin{array}{c}\text { Equivalent years } \\
\text { of record }\end{array}$ \\
\hline 2 & $Q=0.0204 \mathrm{AREA}^{0.606}(\mathrm{ELEV} / 1,000)^{-3.5}$ & 68 & 0.14 \\
5 & $Q=0.181 \mathrm{AREA}^{0.515}(\mathrm{ELEV} / 1,000)^{-2.9}$ & 55 & 0.77 \\
10 & $Q=1.18 \mathrm{AREA}^{0.488}(\mathrm{ELEV} / 1,000)^{-2.2}$ & 52 & 1.70 \\
25 & $\mathrm{Q}=18.2 \mathrm{AREA}^{0.465}(\mathrm{ELEV} / 1,000)^{-1.1}$ & 53 & 2.81 \\
50 & $Q=248 \mathrm{AREA}^{0.449}$ & 57 & 3.36 \\
100 & $Q=292 \mathrm{AREA}^{0.444}$ & 59 & 3.94 \\
\hline
\end{tabular}

a Equation: $Q$, peak flow, in $\mathrm{ft}^{3} \mathrm{sec}^{-1}$; AREA, drainage area, in $\mathrm{mi}^{2}$; ELEV, mean basin elevation, in $\mathrm{ft}$

Table C.10-Hybrid equations for estimating regional flood-frequency relations for the Southern Great Basin Region 10 (Thomas and others 1997). Data were based on 104 stations. Average number of years of systematic record is 21.

\begin{tabular}{cccc}
$\begin{array}{c}\text { Recurrence } \\
\text { interval }(\mathbf{y r})\end{array}$ & Equation $^{\mathbf{a}}$ & $\begin{array}{c}\text { Estimated average standard error } \\
\text { of regression }\end{array}$ & $\begin{array}{c}\text { Equivalent years } \\
\text { of reg units) }\end{array}$ \\
\hline 2 & $Q=12 \mathrm{AREA}^{0.58}$ & 1.14 & 0.618 \\
5 & $Q=85 \mathrm{AREA}^{0.59}$ & 0.602 & 3.13 \\
10 & $Q=200 \mathrm{AREA}^{0.62}$ & 0.675 & 3.45 \\
25 & $Q=400 \mathrm{AREA}^{0.65}$ & 0.949 & 2.49 \\
50 & $Q=590 \mathrm{AREA}^{0.67}$ & 0.928 & 3.22 \\
100 & $Q=850 \mathrm{AREA}^{0.69}$ & 1.23 & 2.22 \\
\hline
\end{tabular}

a Equation: $Q$, peak flow, in $\mathrm{ft}^{3} \mathrm{sec}^{-1}$; AREA, drainage area, in $\mathrm{mi}^{2}$

${ }^{b}$ Estimated average standard error of regression for the hybrid method includes much of the within-station residual variance and therefore is not comparable to standard error of estimate from an ordinary least-squares regression.

Table C.11-Hybrid equations for estimating regional flood-frequency relations for the Northeastern Arizona Region 11 (Thomas and others 1997). Data were based on 46 stations. Average number of years of systematic record is 20.

\begin{tabular}{clcc}
$\begin{array}{c}\text { Recurrence } \\
\text { interval }(\mathbf{y r})\end{array}$ & \multicolumn{1}{c}{ Equation $^{\mathbf{a}}$} & $\begin{array}{c}\text { Estimated average standard error } \\
\text { of regression }\end{array}$ & $\begin{array}{c}\text { Equivalent years } \\
\text { (log units) } \\
\text { of record }\end{array}$ \\
\hline 2 & $Q=26$ AREA $^{0.62}$ & 0.609 & 0.428 \\
5 & $Q=130$ AREA $^{0.56}$ & 0.309 & 2.79 \\
10 & $Q=0.10$ AREA $^{0.52}$ EVAP $^{2.0}$ & 0.296 & 4.63 \\
25 & $Q=0.17$ AREA $^{0.52}$ EVAP $^{2.0}$ & 0.191 & 17.1 \\
50 & $Q=0.24$ AREA $^{0.54}$ EVAP $^{2.0}$ & 0.294 & 9.20 \\
100 & $Q=0.27$ AREA $^{0.58}$ EVAP $^{2.0}$ & 0.863 & 1.32 \\
\hline
\end{tabular}

${ }^{a}$ Equation: $Q$, peak flow, in $\mathrm{ft}^{3} \mathrm{sec}^{-1}$; AREA, drainage area, in $\mathrm{mi}^{2}$; EVAP, mean annual evaporation, in inches

${ }^{b}$ Estimated average standard error of regression for the hybrid method includes much of the within-station residual variance and therefore is not comparable to standard error of estimate from an ordinary least-squares regression. 
Table C.12-Generalized least-squares regression equations for estimating regional flood-frequency relations for the Central Arizona Region 12 (Thomas and others 1997). Data were based on 68 stations. Average number of years of systematic record is 21 .

\begin{tabular}{clcc}
$\begin{array}{c}\text { Recurrence } \\
\text { interval (yr) }\end{array}$ & \multicolumn{1}{c}{ Equation $^{\mathbf{a}}$} & $\begin{array}{c}\text { Average standard error } \\
\text { of prediction (\%) }\end{array}$ & $\begin{array}{c}\text { Equivalent years } \\
\text { of record }\end{array}$ \\
\hline 2 & $Q=41.1 \mathrm{AREA}^{0.629}$ & 105 & 0.23 \\
5 & $Q=238 \mathrm{AREA}^{0.687}(\mathrm{ELEV} / 1,000)^{-0.358}$ & 68 & 1.90 \\
10 & $Q=479 \mathrm{AREA}^{0.661}(\mathrm{ELEV} / 1,000)^{-0.398}$ & 52 & 6.24 \\
25 & $Q=942 \mathrm{AREA}^{0.630}(\mathrm{ELEV} / 1,000)^{-0.383}$ & 40 & 17.8 \\
50 & $Q=10^{\left(7.36-4.17 \mathrm{AREA}^{-0.08}\right)}(\mathrm{ELEV} / 1,000)^{-0.440}$ & 37 & 27.5 \\
100 & $Q=10^{\left(6.55-3.17 \text { AREA }^{-0.11}\right)(E L E V / 1,000)^{-0.454}}$ & 39 & 32.1 \\
\hline
\end{tabular}

${ }^{a}$ Equation: $Q$, peak flow, in $\mathrm{ft}^{3} \mathrm{sec}^{-1}$; AREA, drainage area, in $\mathrm{mi}^{2}$; ELEV, mean basin elevation, in $\mathrm{ft}$

Table C.13-Generalized least-squares regression equations for estimating regional flood-frequency relations for the Southern Arizona Region 13 (Thomas and others 1997). Data were based on 73 stations. Average number of years of systematic record is 21 .

\begin{tabular}{cccc}
$\begin{array}{c}\text { Recurrence } \\
\text { interval (yr) }\end{array}$ & Equation $^{\mathbf{a}}$ & $\begin{array}{c}\text { Average standard error } \\
\text { of prediction (\%) }\end{array}$ & $\begin{array}{c}\text { Equivalent years } \\
\text { of record }\end{array}$ \\
\hline 2 & $Q=10^{\left(6.38-4.29 A R E A^{-0.06}\right)}$ & 57 & 2.0 \\
5 & $Q=10^{\left(5.78-3.31 A R E A^{-0.08}\right)}$ & 40 & 6.25 \\
10 & $Q=10^{\left(5.68-3.02 A R E A^{-0.09}\right)}$ & 37 & 11.1 \\
25 & $Q=10^{\left(5.64-2.78 A R E A^{-0.10}\right)}$ & 39 & 15.0 \\
50 & $Q=10^{\left(5.57-2.59 A R E A^{-0.11}\right)}$ & 43 & 15.9 \\
100 & $Q=10^{\left(5.52-2.42 A R E A^{-0.12}\right)}$ & 48 & 16.1 \\
\hline
\end{tabular}

a Equation: Q, peak flow, in $\mathrm{ft}^{3} \mathrm{sec}^{-1}$; AREA, drainage area, in $\mathrm{mi}^{2}$

Table C.14-Generalized least-squares regression equations for estimating regional flood-frequency relations for the Upper Gila Basin Region 14 (Thomas and others 1997). Data were based on 22 stations. Average number of years of systematic record is 26 .

\begin{tabular}{clcc}
\hline $\begin{array}{c}\text { Recurrence } \\
\text { interval (yr) }\end{array}$ & \multicolumn{1}{c}{ Equation $^{\mathbf{a}}$} & $\begin{array}{c}\text { Average standard error } \\
\text { of prediction (\%) }\end{array}$ & $\begin{array}{c}\text { Equivalent years } \\
\text { of record }\end{array}$ \\
\hline 2 & $Q=583 \mathrm{AREA}^{0.588}(\mathrm{ELEV} / 1,000)^{-1.3}$ & 74 & 1.69 \\
5 & $Q=618 \mathrm{AREA}^{0.524}(\mathrm{ELEV} / 1,000)^{-0.70}$ & 63 & 3.54 \\
10 & $Q=361 \mathrm{AREA}^{0.464}$ & 65 & 4.95 \\
25 & $Q=581 \mathrm{AREA}^{0.462}$ & 63 & 7.75 \\
50 & $Q=779 \mathrm{AREA}^{0.462}$ & 64 & 9.65 \\
100 & $Q=1,010 \mathrm{AREA}^{0.463}$ & 66 & 11.2 \\
\hline
\end{tabular}

a Equation: $Q$, peak flow, in $\mathrm{ft}^{3} \mathrm{sec}^{-1}$; AREA, drainage area, in $\mathrm{mi}^{2}$; ELEV, mean basin elevation, in $\mathrm{ft}$ 
Table C.15-Generalized least-squares regression equations for estimating regional flood-frequency relations for the Upper Rio Grande Basin Region 15 (Thomas and others 1997). Data were based on 17 stations. Average number of years of systematic record is 35 .

\begin{tabular}{|c|c|c|c|}
\hline $\begin{array}{l}\text { Recurrence } \\
\text { interval (yr) }\end{array}$ & Equation $^{\mathrm{a}}$ & $\begin{array}{c}\text { Average } \\
\text { standard error } \\
\text { of prediction (\%) }\end{array}$ & $\begin{array}{c}\text { Equivalent } \\
\text { years } \\
\text { of record }\end{array}$ \\
\hline 2 & $Q=18,700$ AREA $^{0.730}\left(\right.$ ELEV $/ 1,000^{-2.86}\left[\left(\right.\right.$ LONG-99)/10] ${ }^{2.8}$ & 64 & 0.13 \\
\hline 5 & 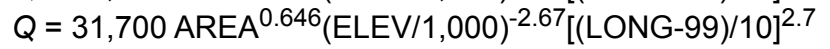 & 66 & 0.64 \\
\hline 10 & $Q=26,000$ AREA $^{0.582}(\text { ELEV } / 1,000)^{-2.27}\left[(\text { LONG-99) } / 10]^{2.7}\right.$ & 68 & 1.24 \\
\hline 25 & $Q=34,800$ AREA $^{0.532}(\text { ELEV } / 1,000)^{-2.15}\left[(\text { LONG-99) } / 10]^{2.6}\right.$ & 71 & 2.04 \\
\hline 50 & $Q=44,200$ AREA $^{0.501}(\text { ELEV } / 1,000)^{-2.11}\left[(\text { LONG-99) } / 10]^{2.5}\right.$ & 73 & 2.60 \\
\hline 100 & $Q=91,800$ AREA $^{0.439}(\text { ELEV } / 1,000)^{-2.22}\left[(\text { LONG-99)/10] }]^{2.5}\right.$ & 76 & 3.12 \\
\hline
\end{tabular}

${ }^{a}$ Equation: $Q$, peak flow, in $\mathrm{ft}^{3} \mathrm{sec}^{-1}$; AREA, drainage area, in $\mathrm{mi}^{2}$; ELEV, mean basin elevation, in $\mathrm{ft}$; LONG, longitude of site, in decimal degrees

Table C.16-Hybrid equations for estimating regional flood-frequency relations for the Southeast Region 16 (Thomas and others 1997). Data were based on 120 stations. Average number of years of systematic record is 30.

\begin{tabular}{|c|c|c|c|}
\hline $\begin{array}{l}\text { Recurrence } \\
\text { interval (yr) }\end{array}$ & Equation $^{a}$ & $\begin{array}{l}\text { Estimated average standard } \\
\text { error of regression }{ }^{\mathrm{b}} \text { (log units) }\end{array}$ & $\begin{array}{l}\text { Equivalent years } \\
\text { of record }\end{array}$ \\
\hline 2 & $Q=14$ AREA $^{0.51}\left(\text { EVAP- }^{2} 2\right)^{0.55}$ & 0.664 & 0.410 \\
\hline 5 & $Q=37$ AREA $^{0.48}\left(\text { EVAP- }^{2} 2\right)^{0.63}$ & 0.269 & 3.77 \\
\hline 10 & $Q=52$ AREA $^{0.47}\left(\right.$ EVAP-32 $^{0.67}$ & 0.177 & 12.6 \\
\hline 25 & $Q=70$ AREA $^{0.48}\left(\text { EVAP- }^{2} 2\right)^{0.74}$ & 0.425 & 3.20 \\
\hline 50 & $Q=110$ AREA $^{0.47}\left(\text { EVAP }^{2} 34\right)^{0.74}$ & 0.367 & 5.38 \\
\hline 100 & $Q=400$ AREA $^{0.50}\left(\text { EVAP }^{2} 37\right)^{0.45}$ & 0.442 & 4.54 \\
\hline
\end{tabular}

a Equation: $Q$, peak flow, in $\mathrm{ft}^{3} \mathrm{sec}^{-1}$; AREA, drainage area, in $\mathrm{mi}^{2}$; EVAP, mean annual evaporation, in inches

${ }^{b}$ Estimated average standard error of regression for the hybrid method includes much of the within-station residual variance and therefore is not comparable to standard error of estimate from an ordinary least-squares regression. 
Table C.17-Regression equations for estimating magnitude and frequency of floods for ungaged sites in California (Jennings and others 1994; Mann and others 2004; Waananen and Crippen 1977).

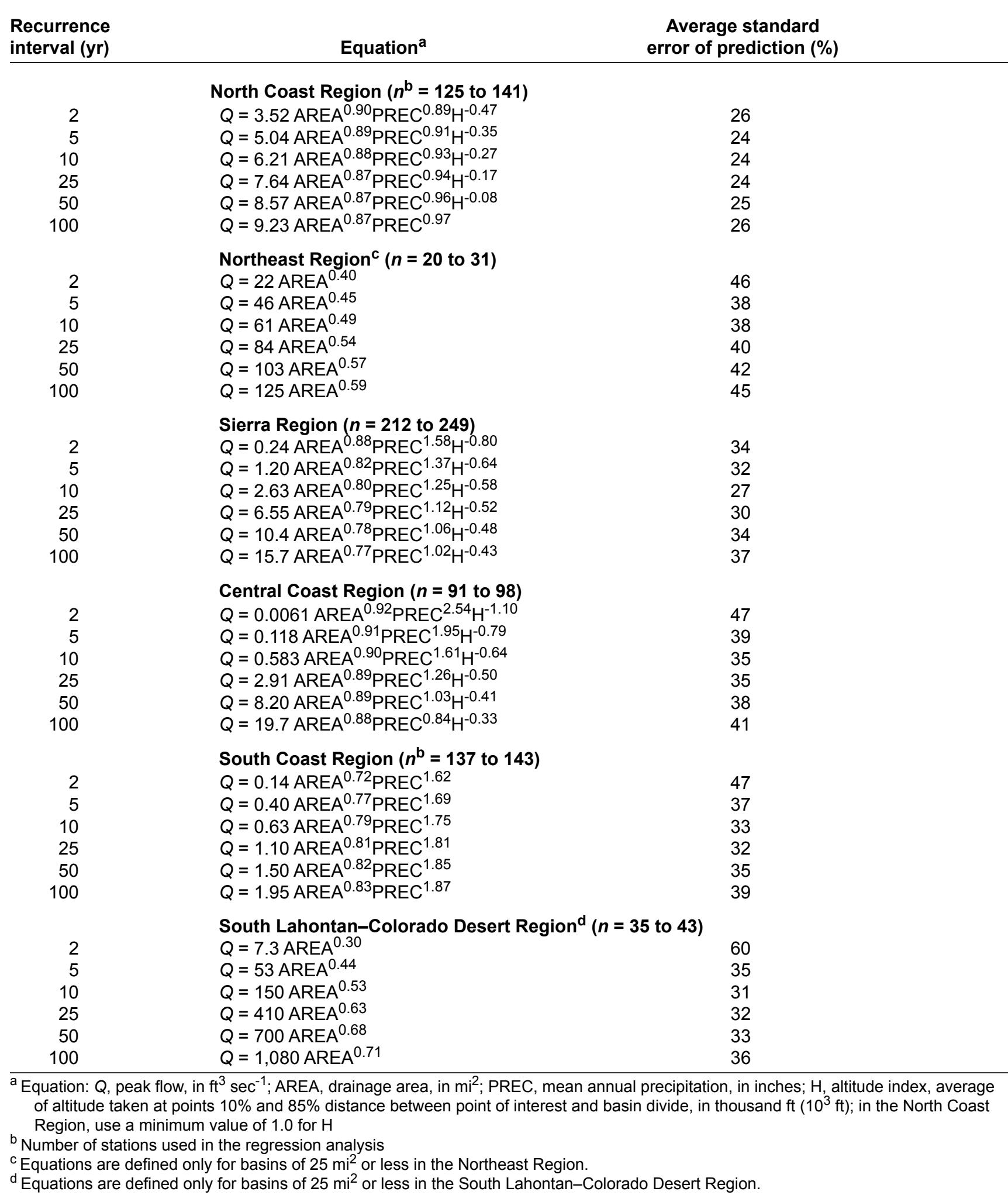


Table C.18-Exponent coefficients for estimation of peak flow of ungaged sites near gaged sites on the same stream in Colorado (Vaill 2000). Flood-frequency relations at sites near gaged sites on the same stream can be estimated using a ratio of drainage area for the ungaged and gaged sites $(A u / A g)$ if the drainage area ratio is between 0.5 and 1.5 .

\begin{tabular}{cc} 
Hydrologic Region & Exponent, $\boldsymbol{x}$ \\
\hline Mountains & 0.69 \\
Rio Grande & 0.88 \\
Southwest & 0.71 \\
Northwest & 0.64 \\
Plains & 0.40 \\
\hline
\end{tabular}

Table C.19-Regional flood-frequency equations for Colorado (Vaill 2000).

\begin{tabular}{|c|c|c|}
\hline $\begin{array}{l}\text { Recurrence } \\
\text { interval (yr) }\end{array}$ & Equation $^{\mathrm{a}}$ & $\begin{array}{l}\text { Average standard error } \\
\text { of prediction (\%) }\end{array}$ \\
\hline $\begin{array}{r}2 \\
5 \\
10 \\
25 \\
50 \\
100 \\
200 \\
500\end{array}$ & $\begin{array}{l}\text { Mountain Region } \\
Q=11.0 \text { AREA }^{0.663}(\mathrm{BS}+1.0)^{3.465} \\
Q=17.9 \text { AREA }^{0.677}(\mathrm{BS}+1.0)^{2.739} \\
Q=23.0 \text { AREA }^{0.685}(\mathrm{BS}+1.0)^{2.364} \\
Q=29.4 \text { AREA }^{0.695}(\mathrm{BS}+1.0)^{2.004} \\
Q=34.5 \text { AREA }^{0.700}(\mathrm{BS}+1.0)^{1.768} \\
Q=39.5 \text { AREA }^{0.706}(\mathrm{BS}+1.0)^{1.577} \\
Q=44.6 \text { AREA }^{0.710}(\mathrm{BS}+1.0)^{1.408} \\
Q=51.5 \text { AREA }^{0.715}(\mathrm{BS}+1.0)^{1.209}\end{array}$ & $\begin{array}{l}52 \\
47 \\
45 \\
44 \\
44 \\
44 \\
45 \\
47\end{array}$ \\
\hline $\begin{array}{r}2 \\
5 \\
10 \\
25 \\
50 \\
100 \\
200 \\
500\end{array}$ & $\begin{array}{l}\text { Rio Grande Region } \\
Q=0.03 \text { AREA }{ }^{0.979} \text { PREC }^{1.615} \\
Q=0.12 \text { AREA }^{0.940} \text { PREC }^{1.384} \\
Q=0.25 \text { AREA }^{0.914} \text { PREC }^{1.277} \\
Q=0.52 \text { AREA }^{0.884} \text { PREC }^{1.1117} \\
Q=0.81 \text { AREA }^{0.864} \text { PREC }^{1.121} \\
Q=1.19 \text { AREA }^{0.846} \text { PREC }^{1.074} \\
Q=1.67 \text { AREA }^{0.828} \text { PREC }^{1.036} \\
Q=2.48 \text { AREA }^{0.808} \text { PREC }^{0.995}\end{array}$ & $\begin{array}{l}61 \\
55 \\
53 \\
51 \\
50 \\
49 \\
49 \\
49\end{array}$ \\
\hline $\begin{array}{r}2 \\
5 \\
10 \\
25 \\
50 \\
100 \\
200 \\
500\end{array}$ & $\begin{array}{l}\text { Southwest Region } \\
Q=28.7 \text { AREA }^{0.699} \\
Q=50.5 \text { AREA }^{0.693} \\
Q=66.0 \text { AREA }^{0.697} \\
Q=86.3 \text { AREA }^{0.704} \\
Q=102.0 \text { AREA }^{0.709} \\
Q=118.4 \text { AREA }^{0.715} \\
Q=135.5 \text { AREA }^{0.720} \\
Q=159.4 \text { AREA }^{0.728}\end{array}$ & $\begin{array}{l}62 \\
58 \\
57 \\
57 \\
58 \\
59 \\
60 \\
62\end{array}$ \\
\hline $\begin{array}{r}2 \\
5 \\
10 \\
25 \\
50 \\
100 \\
200 \\
500\end{array}$ & $\begin{array}{l}\text { Northwest Region } \\
Q=0.39 \text { AREA }^{0.684} \text { PREC }^{1.304} \\
Q=2.84 \text { AREA }^{0.674} \text { PREC }^{0.833} \\
Q=7.56 \text { AREA }^{0.671} \text { PREC }^{0.601} \\
Q=20.6 \text { AREA }^{0.669} \text { PREC }^{0.362} \\
Q=38.8 \text { AREA }^{0.667} \mathrm{PREC}^{0.210} \\
Q=104.7 \text { AREA }^{0.624} \\
Q=118.5 \text { AREA }^{0.624} \\
Q=137.6 \text { AREA }^{0.623}\end{array}$ & $\begin{array}{l}62 \\
58 \\
56 \\
56 \\
56 \\
59 \\
60 \\
61\end{array}$ \\
\hline
\end{tabular}


Table C.19-Continued.

\begin{tabular}{clc}
$\begin{array}{c}\text { Recurrence } \\
\text { interval (yr) }\end{array}$ & \multicolumn{1}{c}{ Equation $^{\mathbf{a}}$} & $\begin{array}{c}\text { Average standard error } \\
\text { of prediction (\%) }\end{array}$ \\
\hline & Plains Region & \\
2 & $Q=39.0$ AREA & \\
5 & $Q=195.48$ AREA $^{0.399}$ & 93 \\
10 & $Q=364.6$ AREA $^{0.400}$ & 89 \\
25 & $Q=725.3$ AREA $^{0.395}$ & 90 \\
50 & $Q=1116$ AREA $^{0.392}$ & 92 \\
100 & $Q=1640$ AREA $^{0.388}$ & 95 \\
200 & $Q=2324$ AREA $^{0.385}$ & 96 \\
500 & $Q=3534$ AREA $^{0.380}$ & 98 \\
\hline
\end{tabular}

a Equation: $Q$, peak flow, in $\mathrm{ft}^{3} \mathrm{sec}^{-1}$; AREA, drainage area, in $\mathrm{mi}^{2}$; PREC, mean annual precipitation, in inches; $\mathrm{BS}$, mean drainage-basin slope, in foot per foot

Table C.20-Exponent coefficients for estimation of peak flow of ungaged sites near gaged sites on the same stream in Idaho (Berenbrock 2002). Flood-frequency relations at sites near gaged sites on the same stream can be estimated using a ratio of drainage area for the ungaged and gaged sites $(\mathrm{Au} / \mathrm{Ag})$ if the drainage area ratio is between 0.5 and 1.5.

\begin{tabular}{cc}
\hline Hydrologic Region & Exponent, $\boldsymbol{x}$ \\
\hline 1 & 0.65 \\
2 & 0.88 \\
3 & 0.84 \\
4 & 0.85 \\
5 & 0.94 \\
6 & 0.80 \\
$7 \mathrm{a}$ & 0.77 \\
$7 \mathrm{~b}$ & 0.65 \\
8 & 0.90 \\
\hline
\end{tabular}


Table C.21-Flood-peak flow regression equations and associated statistics for ungaged sites on unregulated and undiverted streams in Idaho (Berenbrock 2002).

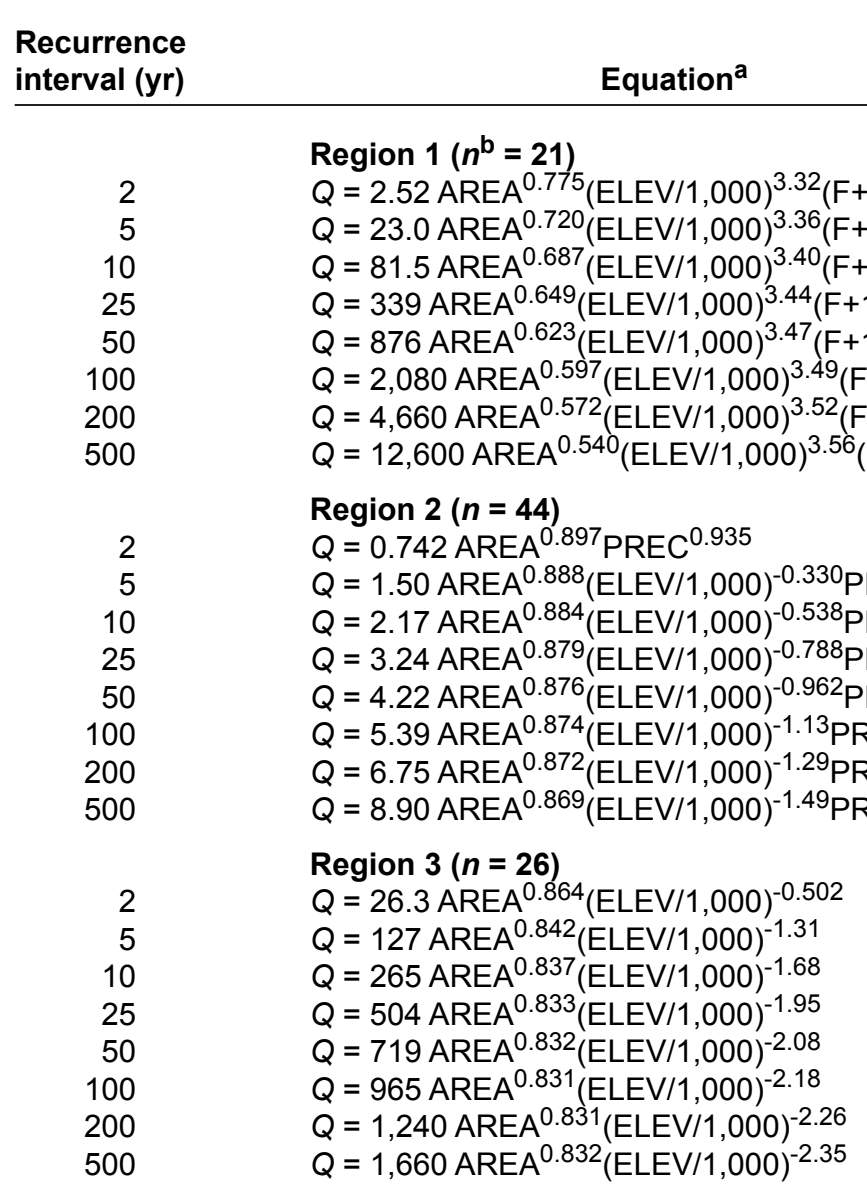

Average standard error of prediction (\%)

$\begin{array}{rl}2 & Q=16.3 \operatorname{AREA}^{0.893}(E L E V / 1,000)^{-0.121} \\ 5 & Q=46.3 \operatorname{AREA}^{0.874}(E L E V / 1,000)^{-0.459} \\ 10 & Q=79.2 \operatorname{AREA}^{0.863}(E L E V / 1,000)^{-0.628} \\ 25 & Q=139 \operatorname{AREA}^{0.852}(E L E V / 1,000)^{-0.801} \\ 50 & Q=198 \operatorname{AREA}^{0.844}(E L E V / 1,000)^{-0.910} \\ 100 & Q=273 \operatorname{AREA}^{0.837}(E L E V / 1,000)^{-1.01} \\ 200 & Q=365 \operatorname{AREA}^{0.831}(E L E V / 1,000)^{-1.10} \\ 500 & Q=521 \operatorname{AREA}^{0.822}(E L E V / 1,000)^{-1.20}\end{array}$

\section{Region $3\left(n^{\mathrm{b}}=\mathbf{6 0}\right)$}

\section{Region 5 ( $n=46)$}

+78.4 to -43.9

+61.1 to -37.9

+56.8 to -36.2

+57.1 to -36.3

+60.1 to -37.6

+64.8 to -39.3

+70.8 to -41.4

+80.1 to -44.5

+64.2 to -39.1

+64.3 to -39.1

+65.8 to -39.7

+68.7 to -40.7

+71.4 to -41.6

+74.1 to -42.6

+77.1 to -43.5

+81.3 to -44.8

+86.4 to -46.4 +58.6 to -36.9

+51.8 to -34.1

+50.3 to -33.5

+51.9 to -34.2

+55.1 to -35.5

+59.4 to -37.3

+66.2 to -39.8

+83.5 to -45.5

+69.1 to -40.9

+63.6 to -38.9

+59.5 to -37.3

+57.7 to -36.6

+56.9 to -36.3

+56.6 to -36.1

+56.9 to -36.3

+46.7 to -31.8

+44.8 to -30.9

+45.0 to -31.1

+46.0 to -31.5

+47.1 to -32.0

+48.4 to -32.6

+49.8 to -33.2

+51.9 to -34.2

\section{Region 6 ( $n=31)$}

$Q=0.000258$ AREA $^{0.893} \mathrm{PREC}^{3.15}$

$Q=0.00223$ AREA $^{0.846}$ PREC $^{2.68}$

$Q=0.00632$ AREA $^{0.824}$ PREC $^{2.45}$

$Q=0.0181$ AREA 0.801 PREC $^{2.22}$

$Q=0.0346$ AREA $^{0.787}$ PREC $^{2.08}$

$Q=0.0607$ AREA $^{0.775}$ PREC $^{1.96}$

$Q=0.100$ AREA $^{0.763}$ PREC $^{1.85}$

$Q=0.180$ AREA $^{0.750}$ PREC $^{1.73}$
+76.5 to -43.4

+68.8 to -40.8

+67.9 to -40.4

+68.8 to -40.8

+70.2 to -41.2

+71.8 to -41.8

+73.8 to -42.4

+76.5 to -43.3 
Table C.21-Continued.

\begin{tabular}{|c|c|c|}
\hline $\begin{array}{l}\text { Recurrence } \\
\text { interval (yr) }\end{array}$ & Equation $^{a}$ & $\begin{array}{c}\text { Average standard error } \\
\text { of prediction (\%) }\end{array}$ \\
\hline $\begin{array}{r}2 \\
5 \\
10 \\
25 \\
50 \\
100 \\
200 \\
500\end{array}$ & 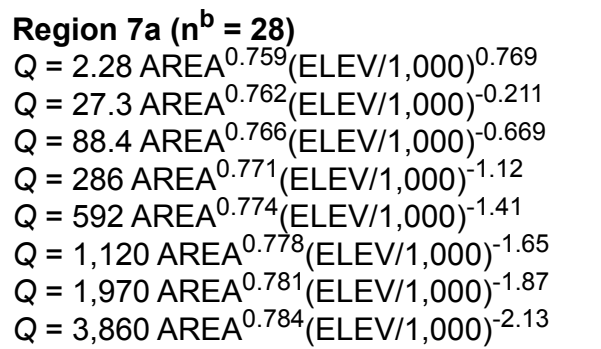 & $\begin{array}{l}+82.3 \text { to }-45.2 \\
+66.6 \text { to }-40.0 \\
+62.2 \text { to }-38.3 \\
+60.6 \text { to }-37.7 \\
+61.4 \text { to }-38.0 \\
+63.3 \text { to }-38.8 \\
+66.2 \text { to }-39.8 \\
+71.1 \text { to }-41.5\end{array}$ \\
\hline $\begin{array}{r}2 \\
5 \\
10 \\
25 \\
50 \\
100 \\
200 \\
500\end{array}$ & $\begin{array}{l}\text { Region } \mathbf{7 b}(\mathbf{n}=\mathbf{1 7}) \\
Q=10.2 \operatorname{AREA}^{0.611} \\
Q=17.1 \operatorname{AREA}^{0.624} \\
Q=22.4 \operatorname{AREA}^{0.633} \\
Q=29.9 \operatorname{AREA}^{0.644} \\
Q=35.7 \operatorname{AREA}^{0.653} \\
Q=41.6 \operatorname{AREA}^{0.662} \\
Q=47.5 \operatorname{AREA}^{0.672} \\
Q=55.5 \operatorname{AREA}^{0.686}\end{array}$ & $\begin{array}{l}+143 \text { to }-58.8 \\
+104 \text { to }-50.9 \\
+86.9 \text { to }-46.5 \\
+73.5 \text { to }-42.3 \\
+68.0 \text { to }-40.5 \\
+66.1 \text { to }-39.8 \\
+66.9 \text { to }-40.1 \\
+71.8 \text { to }-41.8\end{array}$ \\
\hline $\begin{array}{r}2 \\
5 \\
10 \\
25 \\
50 \\
100 \\
200 \\
500\end{array}$ & 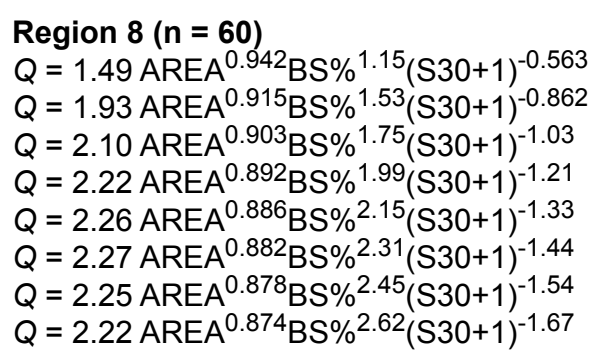 & $\begin{array}{l}+86.9 \text { to }-46.5 \\
+79.8 \text { to }-44.4 \\
+78.3 \text { to }-43.9 \\
+78.2 \text { to }-43.9 \\
+78.9 \text { to }-44.1 \\
+79.9 \text { to }-44.4 \\
+81.2 \text { to }-44.8 \\
+83.2 \text { to }-45.4\end{array}$ \\
\hline
\end{tabular}

Table C.22-Exponent coefficients for estimation of peak flow of ungaged sites near gaged sites on the same stream in Montana (Omang 1992). Flood-frequency relations at sites near gaged sites on the same stream can be estimated using a ratio of drainage area for the ungaged and gaged sites $(A u / A g)$ if the drainage area ratio is between 0.5 and 1.5.

Hydrologic Regions of Montana

\begin{tabular}{|c|c|c|c|c|c|c|c|c|}
\hline $\mathrm{Ta}(\mathrm{yr})$ & West & Northwest & Southwest & $\begin{array}{c}\text { Upper } \\
\text { Yellowstone } \\
\text { Central } \\
\text { Mountain }\end{array}$ & $\begin{array}{c}\text { Northwest } \\
\text { Foothills }\end{array}$ & $\begin{array}{c}\text { Northeast } \\
\text { Plains }\end{array}$ & $\begin{array}{l}\text { East- } \\
\text { Central } \\
\text { Plains }\end{array}$ & $\begin{array}{c}\text { Southeast } \\
\text { Plains }\end{array}$ \\
\hline 2 & 0.94 & 0.94 & 0.87 & 0.85 & 0.49 & 0.69 & 0.55 & 0.55 \\
\hline 5 & 0.90 & 0.87 & 0.82 & 0.79 & 0.48 & 0.65 & 0.53 & 0.53 \\
\hline 10 & 0.89 & 0.84 & 0.78 & 0.77 & 0.47 & 0.63 & 0.52 & 0.52 \\
\hline 100 & 0.85 & 0.74 & 0.68 & 0.70 & 0.48 & 0.59 & 0.49 & 0.50 \\
\hline 500 & 0.83 & 0.67 & 0.64 & 0.65 & 0.50 & 0.57 & 0.47 & 0.49 \\
\hline
\end{tabular}

a Recurrence interval 
Table C.23-Regional flood-frequency equations for Montana based on drainage-basin characteristics (Omang 1992).

\begin{tabular}{|c|c|c|c|}
\hline $\begin{array}{l}\text { Recurrence } \\
\text { interval (yr) }\end{array}$ & Equation $^{a}$ & $\begin{array}{c}\text { Average standard error } \\
\text { of prediction }(\%)\end{array}$ & $\begin{array}{c}\text { Equivalent years } \\
\text { of record }\end{array}$ \\
\hline $\begin{array}{r}2 \\
5 \\
10 \\
25 \\
50 \\
100 \\
500\end{array}$ & $\begin{array}{l}\text { West Region } \\
Q=0.042 \text { AREA }^{0.94} \text { PREC }^{1.49} \\
Q=0.140 \text { AREA }^{0.90} \text { PREC }^{1.31} \\
Q=0.235 \text { AREA }^{0.89} \text { PREC }^{1.25} \\
Q=0.379 \text { AREA }^{0.87} \text { PREC }^{1.19} \\
Q=0.496 \text { AREA }^{0.86} \text { PREC }^{1.17} \\
Q=0.615 \text { AREA }^{0.85} \text { PREC }^{1.15} \\
Q=0.874 \text { AREA }^{0.83} \text { PREC }^{1.14}\end{array}$ & $\begin{array}{l}52 \\
47 \\
45 \\
45 \\
46 \\
48 \\
55\end{array}$ & $\begin{array}{l}1 \\
2 \\
2 \\
3 \\
3 \\
4 \\
4\end{array}$ \\
\hline $\begin{array}{r}2 \\
5 \\
10 \\
25 \\
50 \\
100 \\
500\end{array}$ & $\begin{array}{l}\text { Northwest Region } \\
Q=0.266 \text { AREA } \\
Q=2.94 \text { PREC }^{1.12} \\
Q=7.84 \text { AREA }^{0.87} \text { PREC }^{0.84} \text { PREC }^{0.54} \\
Q=23.1 \text { AREA }^{0.81} \text { PREC }^{0.40} \\
Q=25.4 \text { AREA }^{0.79} \text { PREC }^{0.46} \\
Q=38.9 \text { AREA }^{0.74} \text { PREC }^{0.50} \\
Q=87.1 \text { AREA }^{0.67} \text { PREC }^{0.49}\end{array}$ & $\begin{array}{l}44 \\
34 \\
31 \\
27 \\
26 \\
38 \\
59\end{array}$ & $\begin{array}{r}2 \\
8 \\
13 \\
26 \\
39 \\
24 \\
18\end{array}$ \\
\hline $\begin{array}{r}2 \\
5 \\
10 \\
25 \\
50 \\
100 \\
500\end{array}$ & $\begin{array}{l}\text { Southwest Region } \\
Q=2.48 \operatorname{AREA}^{0.87}(\mathrm{HE}+10)^{0.19} \\
Q=24.8 \operatorname{AREA}^{0.82}(\mathrm{HE}+10)^{-0.16} \\
Q=81.5 \operatorname{AREA}^{0.78}(\mathrm{HE}+10)^{-0.32} \\
Q=297 \operatorname{AREA}^{0.72}(\mathrm{HE}+10)^{-0.49} \\
Q=695 \operatorname{AREA}^{0.70}(\mathrm{HE}+10)^{-0.62} \\
Q=1,520 \operatorname{AREA}^{0.68}(\mathrm{HE}+10)^{-0.74} \\
Q=7,460 \operatorname{AREA}^{0.64}(\mathrm{HE}+10)^{-0.99}\end{array}$ & $\begin{array}{l}88 \\
69 \\
63 \\
60 \\
63 \\
66 \\
80\end{array}$ & $\begin{array}{l}1 \\
2 \\
3 \\
4 \\
5 \\
5 \\
5\end{array}$ \\
\hline $\begin{array}{r}2 \\
5 \\
10 \\
25 \\
50 \\
100 \\
500\end{array}$ & 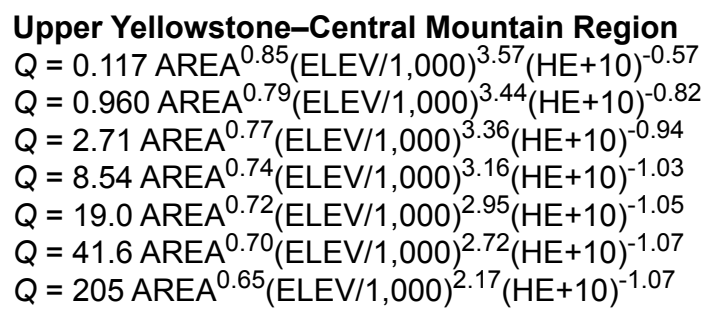 & $\begin{array}{l}72 \\
53 \\
46 \\
44 \\
46 \\
50 \\
63\end{array}$ & $\begin{array}{r}2 \\
7 \\
12 \\
14 \\
14 \\
14 \\
15\end{array}$ \\
\hline $\begin{array}{r}2 \\
5 \\
10 \\
25 \\
50 \\
100 \\
500\end{array}$ & 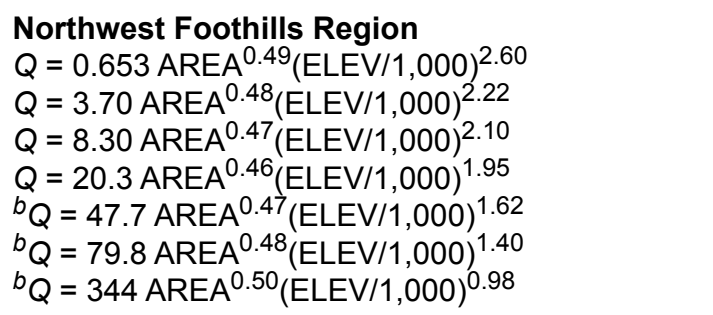 & $\begin{array}{l}88 \\
52 \\
48 \\
50 \\
54 \\
62 \\
75\end{array}$ & $\begin{array}{r}4 \\
13 \\
19 \\
25 \\
28 \\
28 \\
31\end{array}$ \\
\hline $\begin{array}{r}2 \\
5 \\
10 \\
25 \\
50 \\
100 \\
500\end{array}$ & 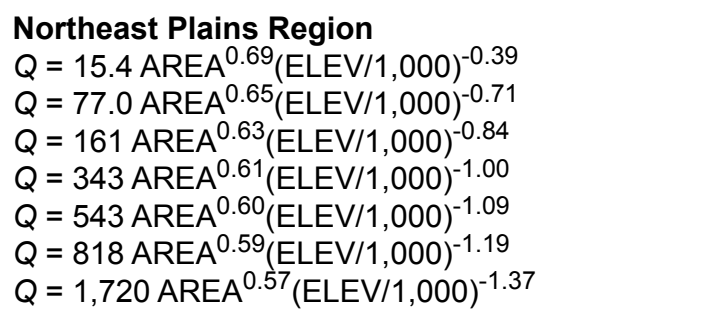 & $\begin{array}{l}85 \\
63 \\
56 \\
53 \\
53 \\
56 \\
68\end{array}$ & $\begin{array}{r}3 \\
6 \\
10 \\
14 \\
17 \\
18 \\
18\end{array}$ \\
\hline $\begin{array}{r}2 \\
5 \\
10 \\
25 \\
50 \\
100 \\
500\end{array}$ & 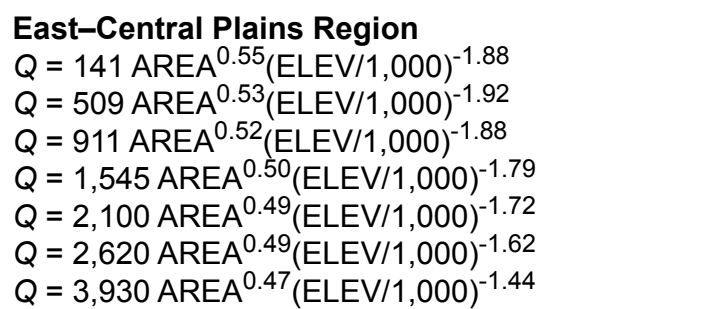 & $\begin{array}{l}99 \\
75 \\
66 \\
62 \\
62 \\
65 \\
75\end{array}$ & $\begin{array}{r}3 \\
5 \\
8 \\
11 \\
14 \\
15 \\
16\end{array}$ \\
\hline
\end{tabular}


Table C.23-Continued.

\begin{tabular}{|c|c|c|c|}
\hline $\begin{array}{l}\text { Recurrence } \\
\text { interval (yr) }\end{array}$ & Equation $^{\mathrm{a}}$ & $\begin{array}{c}\text { Average standard error } \\
\text { of prediction (\%) }\end{array}$ & $\begin{array}{c}\text { Equivalent years } \\
\text { of record }\end{array}$ \\
\hline & Southeast Plains Region & & \\
\hline 2 & $Q=537$ AREA $^{0.55}(E L E V / 1,000)^{-2.91}$ & 134 & 1 \\
\hline 5 & $Q=1,350$ AREA $^{0.53}(\text { ELEV } / 1,000)^{-2.75}$ & 88 & 3 \\
\hline 10 & $Q=2,050$ AREA $^{0.52}\left(E^{2} E V / 1,000\right)^{-2.64}$ & 73 & 5 \\
\hline 25 & $Q=3,240$ AREA $^{0.51}\left({\text { ELEV } / 1,000)^{-2.55}}^{-2.5}\right.$ & 63 & 9 \\
\hline 50 & $Q=4,160$ AREA $^{0.50}(\text { ELEV } / 1,000)^{-2.47}$ & 59 & 12 \\
\hline 100 & $Q=5,850$ AREA $^{0.50}(\mathrm{ELEV} / 1,000)^{-2.51}$ & 62 & 13 \\
\hline 500 & $Q=8,250$ AREA $^{0.49}(\text { ELEV } / 1,000)^{-2.33}$ & 67 & 15 \\
\hline
\end{tabular}

a Equation: $Q$, peak flow, in $\mathrm{ft}^{3} \mathrm{sec}^{-1}$; AREA, drainage area, in $\mathrm{mi}^{2}$; PREC, mean annual precipitation, in inches; ELEV, mean basin elevation, in $\mathrm{ft}$; $\mathrm{HE}$, percentage of basin above $6,000 \mathrm{ft}$ elevation

${ }^{b}$ Equation is not valid if the ungaged stream originates in the Northwest Region

Table C.24-Exponent coefficients for estimation of peak flow of ungaged sites near gaged sites on the same stream in Montana (Parrett and Johnson 2004). Flood-frequency relations at sites near gaged sites on the same stream can be estimated using a ratio of drainage area for the ungaged and gaged sites $(\mathrm{Au} / \mathrm{Ag})$ if the drainage area ratio is between 0.5 and 1.5 .

\section{Hydrologic Regions of Montana}

\begin{tabular}{|c|c|c|c|c|c|c|c|c|}
\hline $\mathrm{T}^{\mathrm{a}}(\mathrm{yr})$ & $\begin{array}{c}\text { West } \\
\text { Region }\end{array}$ & $\begin{array}{c}\text { Northwest } \\
\text { Region }\end{array}$ & $\begin{array}{c}\text { Northwest } \\
\text { Foothills } \\
\text { Region }\end{array}$ & $\begin{array}{c}\text { Northeast } \\
\text { Plains } \\
\text { Region }\end{array}$ & $\begin{array}{l}\text { East- } \\
\text { Central } \\
\text { Plains } \\
\text { Region }\end{array}$ & $\begin{array}{c}\text { Southeast } \\
\text { Plains } \\
\text { Region }\end{array}$ & $\begin{array}{l}\text { Upper } \\
\text { Yellowstone } \\
\text { Central } \\
\text { Mountain } \\
\text { Region }\end{array}$ & $\begin{array}{c}\text { Southwest } \\
\text { Region }\end{array}$ \\
\hline 2 & 0.851 & 0.884 & 0.609 & 0.620 & 0.464 & 0.516 & 0.877 & 0.894 \\
\hline 5 & 0.818 & 0.822 & 0.587 & 0.564 & 0.459 & 0.478 & 0.768 & 0.776 \\
\hline 10 & 0.798 & 0.789 & 0.577 & 0.536 & 0.454 & 0.458 & 0.712 & 0.720 \\
\hline 25 & 0.776 & 0.747 & 0.566 & 0.506 & 0.446 & 0.433 & 0.656 & 0.661 \\
\hline 50 & 0.761 & 0.722 & 0.560 & 0.486 & 0.439 & 0.418 & 0.618 & 0.622 \\
\hline 100 & 0.747 & 0.700 & 0.555 & 0.469 & 0.432 & 0.403 & 0.587 & 0.585 \\
\hline 200 & 0.734 & 0.685 & 0.551 & 0.453 & 0.426 & 0.389 & 0.557 & 0.550 \\
\hline 500 & 0.717 & 0.665 & 0.547 & 0.433 & 0.417 & 0.371 & 0.523 & 0.510 \\
\hline
\end{tabular}

\footnotetext{
a Recurrence interval
} 
Table C.25-Regression equations for Montana based on basin characteristics (Parrett and Johnson 2004).

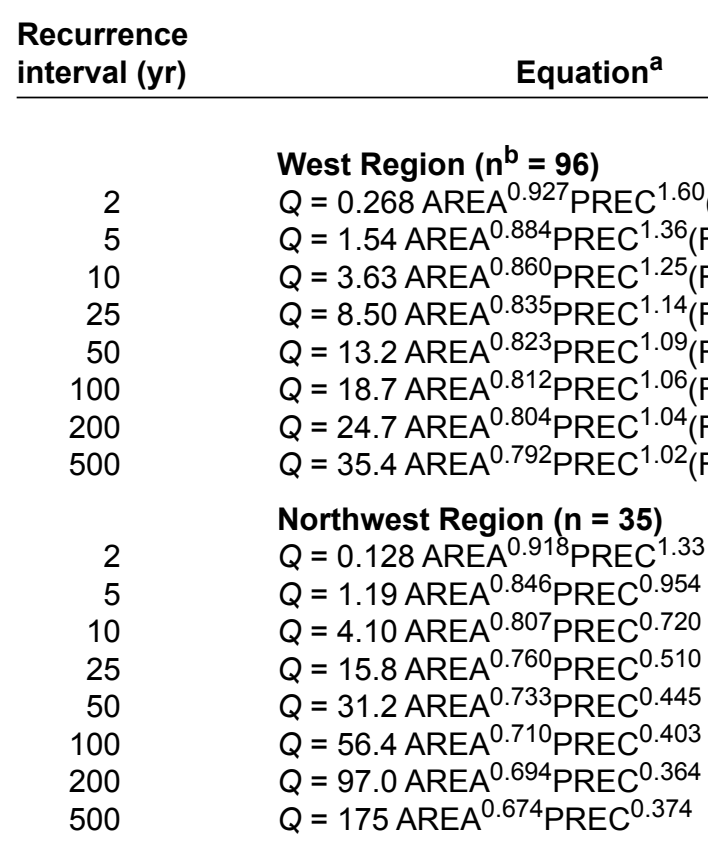

\section{Northwest Foothills Region $(\mathbf{n}=\mathbf{2 4})$}

$Q=14.2$ AREA 0.598

$Q=53.6$ AREA 0.546

$Q=105$ AREA $^{0.546}$

$Q=208$ AREA 0.538

$Q=318$ AREA 0.536

$Q=462$ AREA 0.537

$Q=649$ AREA 0.540

$Q=977$ AREA $^{0.544}$

Northeast Plains Region $\left(\mathrm{n}^{\mathrm{b}}=\mathbf{5 7}\right)$

$Q=30.5$ AREA $^{0.601}(\text { ELEV } / 1,000)^{-0.913}$

$Q=143$ AREA $^{0.547}\left(\text { ELEV }^{0} 1,000\right)^{-1.12}$

$Q=293 \operatorname{AREA}^{0.520}\left(\text { ELEV }^{0} / 1,000\right)^{-1.19}$

$Q=579 \operatorname{AREA}^{0.493}(E L E V / 1,000)^{-1.21}$

$Q=860$ AREA $^{0.477}(\text { ELEV } / 1,000)^{-1.21}$

$Q=1,190$ AREA $^{0.462}\left(\text { ELEV }^{0} 1,000\right)^{-1.20}$

$Q=1,570$ AREA $^{0.450}(\text { ELEV } / 1,000)^{-1.17}$

$Q=2,130$ AREA $^{0.435}(\text { ELEV } / 1,000)^{-1.13}$

\section{East-Central Plains Region $(\mathbf{n}=\mathbf{8 5})$}

$Q=141$ AREA $^{0.495}\left(\mathrm{ELEVV}^{0} / 1,000\right)^{-1.85}$

$Q=661$ AREA $^{0.490}(\mathrm{ELEV} / 1,000)^{-2.09}$

$Q=1,300$ AREA $^{0.482}\left(\text { ELEV }^{0} 1,000\right)^{-2.11}$

$Q=2,360$ AREA $^{0.470}\left(\text { ELEV }^{0} / 1,000\right)^{-2.05}$

$Q=3,240$ AREA $^{0.462}(\text { ELEV } / 1,000)^{-1.96}$

$Q=4,120$ AREA $^{0.454}\left(\text { ELEV }^{0} / 1,000\right)^{-1.84}$

$Q=4,950$ AREA $^{0.446}\left({\text { ELEV } / 1,000)^{-1.72}}^{0.45}\right.$

$Q=5,940$ AREA $^{0.435}(\text { ELEV } / 1,000)^{-1.53}$

Southeast Plains Region $(\boldsymbol{n}=\mathbf{6 9})$

$$
\begin{aligned}
& Q=29.0 \text { AREA }^{0.600}(F+1)^{-0.424} \\
& Q=83.1 \text { AREA }^{0.547}(F+1)^{-0.352} \\
& Q=142 \text { AREA }^{0.517}(\mathrm{~F}+1)^{-0.309} \\
& Q=249 \text { AREA }^{0.483}(\mathrm{~F}+1)^{-0.264} \\
& Q=355 \text { AREA }^{0.461}(\mathrm{~F}+1)^{-0.236} \\
& Q=486 \text { AREA }^{0.441}(\mathrm{~F}+1)^{-0.212} \\
& Q=645 \text { AREA }^{0.422}(\mathrm{~F}+1)^{-0.190} \\
& Q=905 \text { AREA }^{0.401}(\mathrm{~F}+1)^{-0.166}
\end{aligned}
$$

Average standard error of prediction (\%)
Equivalent years

of record

$\begin{array}{lr}60.5 & 0.9 \\ 55.4 & 1.4 \\ 54.3 & 1.9 \\ 54.6 & 2.7 \\ 56.0 & 3.1 \\ 58.5 & 3.4 \\ 62.2 & 3.6 \\ 67.9 & 3.7 \\ & \\ 49.2 & -c \\ 39.2 & - \\ 38.4 & - \\ 38.4 & - \\ 37.4 & - \\ 40.2 & - \\ 46.0 & - \\ 56.9 & - \\ & \\ 99.5 & \\ 59.6 & 2.7 \\ 51.3 & 8.7 \\ 50.8 & 15.5 \\ 55.0 & 22.2 \\ 61.0 & 23.8 \\ 68.2 & 23.8 \\ 79.0 & 23.1 \\ & 21.8\end{array}$

$\begin{array}{ll}91.0 & 3.0\end{array}$

$80.3 \quad 4.3$

$81.3 \quad 5.5$

$87.2 \quad 6.6$

$\begin{array}{ll}93.9 & 7.2\end{array}$

$\begin{array}{ll}101.4 & 7.5\end{array}$

$\begin{array}{ll}109.9 & 7.7\end{array}$

$\begin{array}{ll}123.2 & 7.7\end{array}$

$\begin{array}{ll}99.9 & 3.1\end{array}$

$\begin{array}{ll}76.0 & 5.7 \\ 71.4\end{array}$

$\begin{array}{lr}71.4 & 8.3\end{array}$

$\begin{array}{ll}73.4 & 10.7\end{array}$

$\begin{array}{ll}78.6 & 11.6\end{array}$

$85.7 \quad 12.0$

$94.3 \quad 11.9$

$\begin{array}{ll}107.8 & 11.6\end{array}$

$134.1 \quad 1.5$

$103.9+2.6$

$94.3 \quad 4.0$

$88.9 \quad 6.0$

$\begin{array}{ll}89.1 & 7.3\end{array}$

$91.6 \quad 8.3$

$96.1 \quad 9.0$

$105.5 \quad 9.3$ 
Table C.25-Continued.

\begin{tabular}{|c|c|c|c|}
\hline $\begin{array}{l}\text { Recurrence } \\
\text { interval (yr) }\end{array}$ & Equation ${ }^{\mathrm{a}}$ & $\begin{array}{c}\text { Average standard error } \\
\text { of prediction }(\%)\end{array}$ & $\begin{array}{c}\text { Equivalent years } \\
\text { of record }\end{array}$ \\
\hline & \multicolumn{3}{|c|}{ Upper Yellowstone-Central Mountain Region $\left(n^{b}=92\right)$} \\
\hline 2 & $Q=5.84 \operatorname{AREA}^{0.832}(\mathrm{HE}+1)^{0.098}$ & 94.9 & 1.5 \\
\hline 5 & $Q=21.7 \operatorname{AREA}^{0.782}(\mathrm{HE}+1)^{-0.0295}$ & 72.7 & 3.2 \\
\hline 10 & $Q=42.3$ AREA $^{0.758}(\mathrm{HE}+1)^{0.0915}$ & 63.4 & 5.6 \\
\hline 25 & $Q=82.6 \operatorname{AREA}^{0.733}(\mathrm{HE}+1)^{-0.148}$ & 57.1 & 9.5 \\
\hline 50 & $Q=126 \operatorname{AREA}^{0.716}(\mathrm{HE}+1)^{-0.182}$ & 55.9 & 12.2 \\
\hline 100 & $Q=181 \operatorname{AREA}^{0.702}(\mathrm{HE}+1)^{-0.211}$ & 56.8 & 14.2 \\
\hline 200 & $Q=252 \operatorname{AREA}^{0.689}(\mathrm{HE}+1)^{-0.238}$ & 59.5 & 15.4 \\
\hline \multirow[t]{2}{*}{500} & $Q=375 \operatorname{AREA}^{0.674}(\mathrm{HE}+1)^{-0.271}$ & 65.2 & 15.9 \\
\hline & \multicolumn{3}{|l|}{ Southwest Region ( $n=44)$} \\
\hline 2 & $Q=3.02 \mathrm{AREA}^{0.881}(\mathrm{HE}+1)^{0.0981}$ & 94.4 & 0.9 \\
\hline 5 & $Q=17.1 \mathrm{AREA}^{0.800}(\mathrm{HE}+1)^{-0.104}$ & 79.0 & 1.7 \\
\hline 10 & $Q=41.9 \mathrm{AREA}^{0.765}(\mathrm{HE}+1)^{-0.214}$ & 75.9 & 2.4 \\
\hline 25 & $Q=109 \operatorname{AREA}^{0.728}(\mathrm{HE}+1)^{-0.332}$ & 75.6 & 3.4 \\
\hline 50 & $Q=201 \mathrm{AREA}^{0.704}(\mathrm{HE}+1)^{-0.408}$ & 77.4 & 4.0 \\
\hline 100 & $Q=351 \operatorname{AREA}^{0.682}(\mathrm{HE}+1)^{-0.476}$ & 80.3 & 4.5 \\
\hline 200 & $Q=582 \operatorname{AREA}^{0.660}(\mathrm{HE}+1)^{-0.537}$ & 83.8 & 4.9 \\
\hline 500 & $Q=1,060$ AREA $^{0.636}(\mathrm{HE}+1)^{-0.611}$ & 89.9 & 5.3 \\
\hline
\end{tabular}

a Equation: $\mathrm{Q}$, peak flow, in $\mathrm{ft}^{3} \mathrm{sec}^{-1}$; AREA, drainage area, in $\mathrm{mi}^{2}$; PREC, mean annual precipitation, in inches; ELEV, mean basin elevation, in $\mathrm{ft}$; $\mathrm{HE}$, percentage of basin above $6,000 \mathrm{ft}$ elevation; F, percentage of basin covered by forest

${ }^{b}$ Number of stations used in the regression analysis

${ }^{\mathrm{c}}$ Not applicable 
Table C.26-Exponent coefficients for estimation of peak flow of ungaged sites near gaged sites on the same stream in New Mexico (Mason and others 2000; Waltemeyer 1996). Flood-frequency relations at sites near gaged sites on the same stream can be estimated using a ratio of drainage area for the ungaged and gaged sites $\left(A_{u} / A_{q}\right)$ if the drainage area ratio is between 0.5 and 1.5 .

\begin{tabular}{|c|c|c|c|c|c|c|c|c|c|}
\hline \multirow[b]{2}{*}{$\begin{array}{l}\text { Recurrence } \\
\text { interval (yr) }\end{array}$} & \multicolumn{9}{|c|}{ Hydrologic Regions of New Mexico } \\
\hline & $\begin{array}{c}\text { Region } 1 \\
\text { Northeast } \\
\text { Plains } \\
\end{array}$ & $\begin{array}{c}\text { Region } 2 \\
\text { Northwest } \\
\text { Plateau } \\
\end{array}$ & $\begin{array}{l}\text { Region } 3 \\
\text { Southeast } \\
\text { Mountain }\end{array}$ & $\begin{array}{c}\text { Region } 4 \\
\text { Southeast } \\
\text { Plains } \\
\end{array}$ & $\begin{array}{l}\text { Region } 5 \\
\text { Northern } \\
\text { Mountain }\end{array}$ & $\begin{array}{c}\text { Region } 6 \\
\begin{array}{c}\text { Central Valley } \\
\text { Mountain }\end{array} \\
\end{array}$ & $\begin{array}{c}\text { Region } 7 \\
\text { Southwest } \\
\text { Desert }\end{array}$ & $\begin{array}{c}\text { Region } 8 \\
\text { Southwest } \\
\text { Mountain }\end{array}$ & $\begin{array}{c}\text { Statewide } \\
\text { small } \\
\text { basin }^{\mathbf{a}}\end{array}$ \\
\hline 2 & 0.53 & 0.47 & 0.60 & 0.51 & 0.83 & 0.50 & 0.46 & 0.19 & 0.39 \\
\hline 5 & 0.50 & 0.46 & 0.67 & 0.54 & 0.81 & 0.47 & 0.48 & 0.23 & 0.42 \\
\hline 10 & 0.49 & 0.46 & 0.70 & 0.55 & 0.81 & 0.46 & 0.49 & 0.25 & 0.43 \\
\hline 25 & 0.48 & 0.45 & 0.75 & 0.57 & 0.80 & 0.44 & 0.50 & 0.27 & 0.44 \\
\hline 50 & 0.48 & 0.45 & 0.78 & 0.58 & 0.80 & 0.43 & 0.51 & 0.29 & 0.45 \\
\hline 100 & 0.48 & 0.45 & 0.81 & 0.59 & 0.80 & 0.42 & 0.52 & 0.30 & 0.46 \\
\hline 500 & 0.48 & 0.45 & 0.87 & 0.62 & 0.80 & 0.40 & 0.55 & 0.32 & 0.47 \\
\hline
\end{tabular}

a Statewide small basin has basin size of $10 \mathrm{mi}^{2}$ or less, and mean basin elevation of less than $7,500 \mathrm{ft}$

Table C.27-Flood-peak flow regression equations and associated statistics for streams that drain rural areas in New Mexico (Mason and others 2000; Waltemeyer 1996).

\begin{tabular}{|c|c|c|}
\hline $\begin{array}{l}\text { Recurrence } \\
\text { interval (yr) } \\
\end{array}$ & Equation $^{a}$ & $\begin{array}{c}\text { Average standard error } \\
\text { of prediction (\%) }\end{array}$ \\
\hline & Northeast Plains Region (Hydrologic Region 1 in New Mexico) & \\
\hline 2 & $Q=114 A_{R E A}^{0.53}$ & 96 \\
\hline 5 & $Q=307$ AREA $^{0.50}$ & 78 \\
\hline 10 & $Q=508$ AREA $^{0.49}$ & 75 \\
\hline 25 & $Q=853 \mathrm{AREA}^{0.48}$ & 72 \\
\hline 50 & $Q=1,180$ AREA $^{0.48}$ & 72 \\
\hline 100 & $Q=1,580$ AREA $^{0.48}$ & 75 \\
\hline \multirow[t]{2}{*}{500} & $Q=2,800$ AREA $^{0.48}$ & 82 \\
\hline & Northwest Plateau Region (Hydrologic Region 2 in New Mexico) & \\
\hline 2 & $Q=84.7$ AREA $^{0.47}$ & 111 \\
\hline 5 & $Q=197$ AREA $^{0.46}$ & 82 \\
\hline 10 & $Q=306$ AREA $^{0.46}$ & 72 \\
\hline 25 & $Q=486$ AREA $^{0.45}$ & 66 \\
\hline 50 & $Q=654 \mathrm{AREA}^{0.45}$ & 63 \\
\hline 100 & $Q=853$ AREA $^{0.45}$ & 63 \\
\hline \multirow[t]{2}{*}{500} & $Q=1,450$ AREA $^{0.45}$ & 66 \\
\hline & Southeast Mountain Region (Hydrologic Region 3 in New Mexico) & \\
\hline 2 & $Q=8,540,000$ AREA $^{0.60}(\text { ELEV } / 1,000)^{-5.96}$ & 36 \\
\hline 5 & $Q=71,400,000$ AREA $^{0.67}\left(E_{L E V} / 1,000\right)^{-6.69}$ & 38 \\
\hline 10 & $Q=160,000,000$ AREA $^{0.70}(\text { ELEV } / 1,000)^{-6.94}$ & 41 \\
\hline 25 & $Q=304,000,000$ AREA $^{0.75}(\text { ELEV } / 1,000)^{-7.10}$ & 43 \\
\hline 50 & $Q=415,000,000$ AREA $^{0.78}(\text { ELEV } / 1,000)^{-7.16}$ & 46 \\
\hline 100 & $Q=521,000,000$ AREA $^{0.81}(\text { ELEV } / 1,000)^{-7.19}$ & 49 \\
\hline \multirow[t]{2}{*}{500} & $Q=711,000,000$ AREA $^{0.87}(\text { ELEV } / 1,000)^{-7.20}$ & 60 \\
\hline & Southeast Plains Region (Hydrologic Region 4 in New Mexico) & \\
\hline 2 & $Q=81.7$ AREA $^{0.51}$ & 192 \\
\hline 5 & $Q=236$ AREA $^{0.54}$ & 124 \\
\hline 10 & $Q=407$ AREA $^{0.55}$ & 103 \\
\hline 25 & $Q=721$ AREA $^{0.57}$ & 88 \\
\hline 50 & $Q=1,040$ AREA $^{0.58}$ & 78 \\
\hline 100 & $Q=1,430$ AREA $^{0.59}$ & 72 \\
\hline 500 & $Q=2,720$ AREA $^{0.62}$ & 66 \\
\hline
\end{tabular}


Northern Mountain Region (Hydrologic Region 5 in New Mexico)

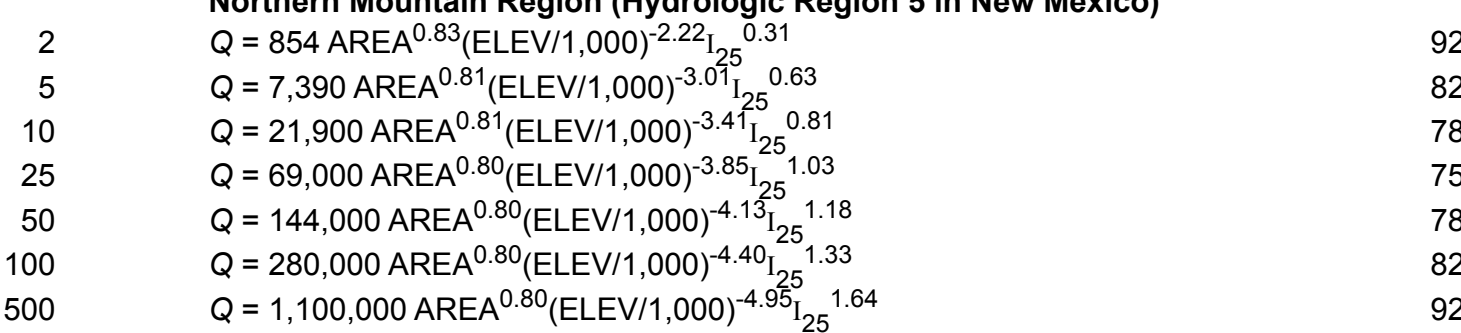

Central Mountain Valley Region (Hydrologic Region 6 in New Mexico)

$Q=747,000 \operatorname{AREA}^{0.50}(\mathrm{CE} / 1,000)^{-5.28} \mathrm{I}_{10} 1.18$

$Q=257,000$ AREA $^{0.47}(\mathrm{CE} / 1,000)^{-4.49} \mathrm{I}_{10} 1.76$

$Q=153,000$ AREA $^{0.46}(\mathrm{CE} / 1,000)^{-4.09} \mathrm{I}_{10} 2.06$

$Q=88,900 \operatorname{AREA}^{0.44}(\mathrm{CE} / 1,000)^{-3.67} \mathrm{I}_{10} 2.37$

57

25

$Q=61,100 \operatorname{AREA}^{0.43}(\mathrm{CE} / 1,000)^{-3.38} \mathrm{I}_{10}{ }^{2.57}$

46

$Q=41,800 \operatorname{AREA}^{0.42}(\mathrm{CE} / 1,000)^{-3.09} \mathrm{I}_{10}, 2.74$

43

100

$Q=17,800 \operatorname{AREA}^{0.40}(\mathrm{CE} / 1,000)^{-2.45} \mathrm{I}_{10} 3.03$

Southwest Desert Region (Hydrologic Region 7 in New Mexico)

$Q=128$ AREA $^{0.46}$

$Q=246$ AREA $^{0.48}$

$Q=345$ AREA $^{0.49}$

$Q=491$ AREA $^{0.50}$

$Q=615$ AREA $^{0.51}$

$Q=751$ AREA $^{0.52}$

$Q=1,120$ AREA $^{0.55}$

Southwest Mountain Region (Hydrologic Region 8 in New Mexico)

$\begin{array}{lr}Q=25,800,000 \operatorname{AREA}^{0.19}(\mathrm{CE} / 1,000)^{-6.10} & 88 \\ Q=14,900,000 \operatorname{AREA}^{0.23}(\mathrm{CE} / 1,000)^{-5.53} & 85 \\ Q=10,300,000 \mathrm{AREA}^{0.25}(\mathrm{CE} / 1,000)^{-5.19} & 85 \\ Q=6,530,000 \mathrm{AREA}^{0.27}(\mathrm{CE} / 1,000)^{-4.80} & 88 \\ Q=4,690,000 \mathrm{AREA}^{0.29}(\mathrm{CE} / 1,000)^{-4.52} & 92 \\ Q=3,400,000 \operatorname{AREA}^{0.30}(\mathrm{CE} / 1,000)^{-4.25} & 96 \\ Q=1,660,000 \operatorname{AREA}^{0.32}(\mathrm{CE} / 1,000)^{-3.68} & 116\end{array}$

Statewide small basin, less than $10 \mathrm{mi}^{2}$ and less than $7,500 \mathrm{ft}$ mean basin elevation

$\begin{array}{lr}Q=107 \text { AREA }^{0.39} & 120 \\ Q=243 \text { AREA }^{0.42} & 88 \\ Q=374 \text { AREA }^{0.43} & 75 \\ Q=591 \text { AREA }^{0.44} & 69 \\ Q=792 \text { AREA }^{0.45} & 66 \\ Q=1,030 \text { AREA }^{0.46} & 63 \\ Q=1,730 \text { AREA }^{0.47} & 63\end{array}$

a Equation: $\mathrm{Q}$, peak flow, in $\mathrm{ft}^{3} \mathrm{sec}^{-1}$; AREA, drainage area, in $\mathrm{mi}^{2}$; ELEV, mean basin elevation, in $\mathrm{ft}$; CE, average channel elevation, in $\mathrm{ft}$ above sea level; $I_{10}$, maximum precipitation intensity, 24-hour precipitation intensity, in inches, with a recurrence interval of 10 years; $\mathrm{I}_{25}$, maximum precipitation intensity, 24-hour precipitation intensity, in inches, with a recurrence interval of 25 years 
Table C.28-Regression equations for estimating magnitude and frequency of floods for ungaged sites in western Oregon (Harris and others 1979; Jennings and others 1994).

\begin{tabular}{|c|c|c|}
\hline $\begin{array}{l}\text { Recurrence } \\
\text { interval (yr) }\end{array}$ & Equation $^{\mathrm{a}}$ & $\begin{array}{c}\text { Average standard error } \\
\text { of prediction (\%) }\end{array}$ \\
\hline & Coast Region $\left(n^{b}=40\right)$ & \\
\hline 2 & $Q=4.59 \operatorname{AREA}^{0.96}(\mathrm{ST}+1)^{-0.45} \mathrm{I}_{2}{ }^{1.91}$ & 33 \\
\hline 5 & 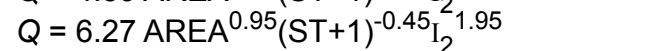 & 32 \\
\hline 10 & $\mathrm{Q}=7.32 \mathrm{AREA}^{0.94}(\mathrm{ST}+1)^{-0.45_{\mathrm{I}}{ }^{2} 1.97}$ & 33 \\
\hline 25 & $Q=8.71 \mathrm{AREA}^{0.93}(\mathrm{ST}+1)^{-0.45_{\mathrm{I}_{2}}{ }^{1.99}}$ & 34 \\
\hline 50 & $Q=9.73 \operatorname{AREA}^{0.93}(\mathrm{ST}+1)^{-0.44} \mathrm{I}_{2}^{2.01}$ & 35 \\
\hline \multirow[t]{2}{*}{100} & $Q=10.7 \operatorname{AREA}^{0.92}(\mathrm{ST}+1)^{-0.44} \mathrm{I}_{2}^{2} 2.02$ & 37 \\
\hline & Willamette Region $(n=111)$ & \\
\hline 2 & $Q=8.70$ AREA $^{0.87} \mathrm{I}_{2}^{1.71}$ & 33 \\
\hline 5 & $Q=15.6 \operatorname{AREA}^{0.88_{\mathrm{I}_{2}}{ }^{2}}$ & 33 \\
\hline 10 & $Q=21.5 \operatorname{AREA}^{0.88} \mathrm{I}_{2} 1.46$ & 33 \\
\hline 25 & $Q=30.3$ AREA $^{0.88}{ }_{I_{2}}{ }^{2} .37$ & 34 \\
\hline 50 & $Q=38.0 \operatorname{AREA}^{0.88}{ }_{\mathrm{I}_{2}}^{2}{ }^{1.31}$ & 36 \\
\hline \multirow[t]{2}{*}{100} & $Q=46.9 \operatorname{AREA}^{0.88} \mathrm{I}_{2}{ }^{1.25}$ & 37 \\
\hline & Rogue-Umpqua Region $(n=60)$ & \\
\hline 2 & $Q=24.2 \operatorname{AREA}^{0.86}(\mathrm{ST}+1)^{-1.16} \mathrm{I}_{2}{ }^{1.15}$ & 44 \\
\hline 5 & $Q=36.0$ AREA $^{0.88}(\mathrm{ST}+1)^{-1.25} \mathrm{I}_{2}{ }^{2} .15$ & 43 \\
\hline 10 & $Q=44.8 \operatorname{AREA}^{0.88}(\mathrm{ST}+1)^{-1.28} \mathrm{I}_{2}{ }^{1.14}$ & 44 \\
\hline 25 & $Q=56.9 \operatorname{AREA}^{0.89}(\mathrm{ST}+1)^{-1.31} \mathrm{I}_{2} 1.12$ & 46 \\
\hline 50 & $Q=66.7 \operatorname{AREA}^{0.90}(\mathrm{ST}+1)^{-1.33} \mathrm{I}_{2} 1.10$ & 49 \\
\hline \multirow[t]{2}{*}{100} & $Q=77.3 \operatorname{AREA}^{0.90}(\mathrm{ST}+1)^{-1.34} \mathrm{I}_{2}{ }^{2} 1.08$ & 51 \\
\hline & High Cascades Region $(n=28)$ & \\
\hline 2 & $Q=4.75 \operatorname{AREA}^{0.90}(\mathrm{ST}+1)^{-0.62}(101-\mathrm{F})^{0.11} \mathrm{I}_{2}{ }^{1.17}$ & 55 \\
\hline 5 & $Q=8.36 \operatorname{AREA}^{0.86}(\mathrm{ST}+1)^{-0.81}(101-\mathrm{F})^{0.08} \mathrm{I}_{2}{ }^{1.30}$ & 50 \\
\hline 10 & $Q=11.3 \operatorname{AREA}^{0.85}(\mathrm{ST}+1)^{-0.92}(101-\mathrm{F})^{0.07} \mathrm{I}_{2}{ }^{1.37}$ & 53 \\
\hline 25 & $Q=15.4 \operatorname{AREA}^{0.83}(\mathrm{ST}+1)^{-1.03}(101-\mathrm{F})^{0.05} \mathrm{I}_{2}{ }^{1.46}$ & 59 \\
\hline 50 & $Q=18.8 \operatorname{AREA}^{0.82}(\mathrm{ST}+1)^{-1.10}(101-\mathrm{F})^{0.04} \mathrm{I}_{2}^{1.52}$ & 66 \\
\hline 100 & $Q=22.6 \operatorname{AREA}^{0.81}(\mathrm{ST}+1)^{-1.17}(101-\mathrm{F})^{0.03} \mathrm{I}_{2}{ }^{1.57}$ & 72 \\
\hline
\end{tabular}

${ }^{a}$ Equation: $Q$, peak flow, in $\mathrm{ft}^{3} \mathrm{sec}^{-1}$; AREA, drainage area, in $\mathrm{mi}^{2}$; ST, storage, area of lakes and ponds, in percent; $\mathrm{I}_{2}$, maximum precipitation intensity, 24-hour precipitation intensity, in inches, with a recurrence interval of 2 years (fig. C.14); F, percentage of basin covered by forest

${ }^{b}$ Number of stations used in the regression analysis

Table C.29—Regression equations for estimating magnitude and frequency of floods for ungaged sites in eastern Oregon (Harris and Hubbard 1983; Jennings and others 1994).

Recurrence interval (yr)
Average standard error of prediction (\%)

\begin{tabular}{|c|c|}
\hline 2 & $\begin{array}{l}\text { North Central Region } \\
Q=0.00013 \text { AREA }{ }^{0.80} P R E\end{array}$ \\
\hline 5 & $Q=0.00068$ AREA $^{0.76} \mathrm{PRE}$ \\
\hline 10 & $Q=0.00134 \mathrm{AREA}^{0.74} \mathrm{PRE}$ \\
\hline 25 & $Q=0.00325$ AREA $^{0.72} \mathrm{PR}$ \\
\hline 50 & $Q=0.00533 \mathrm{AREA}^{0.70} \mathrm{PR}$ \\
\hline 100 & $Q=0.00863$ AREA ${ }^{0.69} P R$ \\
\hline 2 & $\begin{array}{l}\text { East Cascade Region } \\
Q=0.017 \mathrm{CL}^{1.72} \mathrm{PREC}^{1.32}\end{array}$ \\
\hline 5 & $Q=0.118 C L^{1.59}$ PREC $^{1.01}$ \\
\hline 10 & $Q=0.319 C L^{1.53} P R E C^{0.85}$ \\
\hline 25 & $Q=0.881 \mathrm{CL}^{1.46} \mathrm{PREC}^{0.68}$ \\
\hline 50 & $Q=1.67 \mathrm{CL}^{1.42} \mathrm{PREC}^{0.58}$ \\
\hline 100 & $Q=2.92 \mathrm{CL}^{1.39} \mathrm{PREC}^{0.49}$ \\
\hline
\end{tabular}

41 to 51

41 to 51 


\begin{tabular}{cc}
$\begin{array}{c}\text { Recurrence } \\
\text { interval (yr) }\end{array}$ & \multicolumn{1}{c}{ Equation $^{\mathbf{a}}$} \\
\hline & \\
& Southeast Region \\
2 & $Q=0.105 \mathrm{AREA}^{0.79} \mathrm{MnJT}^{1.67}$ \\
5 & $\mathrm{Q}=0.328 \mathrm{AREA}^{0.77} \mathrm{MnJT}^{1.52}$ \\
10 & $\mathrm{Q}=0.509 \mathrm{AREA}^{0.77} \mathrm{MnJT}^{1.50}$ \\
25 & $\mathrm{Q}=0.723 \mathrm{AREA}^{0.75} \mathrm{MnJT}^{1.52}$ \\
50 & $\mathrm{Q}=0.872 \mathrm{AREA}^{0.76} \mathrm{MnJT}^{1.52}$ \\
100 & $\mathrm{Q}=0.960 \mathrm{AREA}^{0.75} \mathrm{MnJT}^{1.57}$
\end{tabular}

\section{Northeast Region}

$Q=0.508$ AREA $^{0.82} \operatorname{PREC}^{1.36}(1+\mathrm{F})^{-0.27}$

$Q=2.44$ AREA $^{0.79}$ PREC $^{1.09}(1+\mathrm{F})^{-0.30}$

$Q=5.28$ AREA $^{0.78}$ PREC $^{0.96}(1+F)^{-0.32}$

$Q=11.8$ AREA $^{0.77}$ PREC $^{0.83}(1+F)^{-0.35}$

$Q=19.8$ AREA $^{0.76}$ PREC $^{0.75}(1+\mathrm{F})^{-0.36}$

$Q=30.7 \operatorname{AREA}^{0.76} \operatorname{PREC}^{0.68}(1+\mathrm{F})^{-0.38}$
Average standard error

of prediction (\%)
41 to 51

41 to 51

${ }^{a}$ Equation: $Q$, peak flow, in $\mathrm{ft}^{3} \mathrm{sec}^{-1}$; AREA, drainage area, in $\mathrm{mi}^{2}$; PREC, mean annual precipitation, in inches; MnJT, mean minimum January air temperature, in degrees Fahrenheit; $C L$, main channel length, in miles; F, percentage of basin covered by forest

Table C.30—Prediction equations for estimating peak flow for ungaged watershed in western Oregon (Cooper 2005).

\begin{tabular}{|c|c|c|c|}
\hline $\begin{array}{l}\text { Recurrence } \\
\text { interval (yr) }\end{array}$ & Equation $^{\mathrm{a}}$ & $\begin{array}{c}\text { Average } \\
\text { prediction } \\
\text { error (\%) }\end{array}$ & $\begin{array}{c}\text { Equivalent } \\
\text { years } \\
\text { of record }\end{array}$ \\
\hline & \multicolumn{3}{|l|}{ Region 1: Coastal watersheds } \\
\hline 2 & $Q=0.05056$ AREA $^{0.9489} \mathrm{I}_{2}{ }^{1.360} \mathrm{MxJT}^{1.280} \mathrm{SC}^{-0.4421} \mathrm{SP}^{-0.1576}$ & 26.8 & 2.4 \\
\hline 5 & $Q=0.01316$ AREA $^{0.9385} \mathrm{I}_{2}{ }^{1.272} \mathrm{MxJT}^{1.738} \mathrm{SC}^{-0.5026} \mathrm{SP}^{-0.2234}$ & 25.3 & 3.7 \\
\hline 10 & $Q=0.008041$ AREA $^{0.9324} \mathrm{I}_{2}{ }^{1.226} \mathrm{MxJT}^{1.926} \mathrm{SC}^{-0.5267} \mathrm{SP}^{-0.2552}$ & 25.6 & 5.0 \\
\hline 25 & 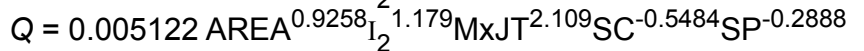 & 26.6 & 6.4 \\
\hline 50 & $Q=0.003888$ AREA $^{0.9215^{2}}{ }_{2}^{1.151} \mathrm{MxJT}^{2.223} \mathrm{SC}^{-0.5605} \mathrm{SP}^{-0.3111}$ & 27.8 & 7.2 \\
\hline 100 & $Q=0.003048$ AREA $^{0.9176}{ }_{\mathrm{I}_{2}}{ }^{1.126} \mathrm{MxJT}^{2.325} \mathrm{SC}^{-0.5701} \mathrm{SP}^{-0.3319}$ & 29.1 & 7.9 \\
\hline \multirow[t]{2}{*}{500} & 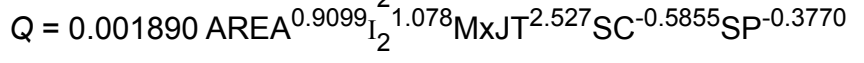 & 32.6 & 8.9 \\
\hline & \multicolumn{3}{|c|}{ Region 2A: Western interior watersheds with mean elevations greater than $3,000 \mathrm{ft}$} \\
\hline 2 & $Q=0.003119$ AREA $^{1.021} \mathrm{BS}_{\mathrm{o}}^{0.8124} \mathrm{I}_{2}{ }^{2.050} \mathrm{MnJT}^{3.541} \mathrm{MxJT} T^{-1.867}$ & 38.7 & 2.2 \\
\hline 5 & $Q=0.007824$ AREA $^{1.020} \mathrm{BS}_{\mathrm{o}}^{0.9022} \mathrm{I}_{2}{ }^{1.649} \mathrm{MnJT}^{3.611} \mathrm{MxJT}^{-2.017}$ & 33.8 & 4.2 \\
\hline 10 & $Q=0.01546$ AREA $^{1.021} \mathrm{BS}_{\mathrm{o}}^{0.9506} \mathrm{I}_{2}{ }^{1.471} \mathrm{MnJT}^{3.620} \mathrm{MxJT}^{-2.137}$ & 32.5 & 6.1 \\
\hline 25 & $Q=0.03353 \mathrm{AREA}^{1.021} \mathrm{BS}_{\mathrm{o}}^{0.9930} \mathrm{I}_{2}^{2}{ }^{1.321} \mathrm{MnJT}^{3.624} \mathrm{MxJT}^{-2.278}$ & 32.5 & 8.6 \\
\hline 50 & $Q=0.05501 \mathrm{AREA}^{1.022} \mathrm{BS}_{\mathrm{O}}{ }^{1.014} \mathrm{I}_{2}{ }^{1.243} \mathrm{MnJT}^{3.624} \mathrm{MxJT}^{-2.366}$ & 33.2 & 10.3 \\
\hline 100 & $Q=0.08492$ AREA $^{1.022} \mathrm{BS}_{\mathrm{O}}{ }^{1.030} \mathrm{I}_{2}{ }^{1.182} \mathrm{MnJT}^{3.621} \mathrm{MxJT}^{-2.440}$ & 34.4 & 11.6 \\
\hline \multirow[t]{2}{*}{500} & $Q=0.1974 \mathrm{AREA}^{1.023} \mathrm{BS}_{\mathrm{O}}{ }^{1.053} \mathrm{I}_{2}{ }^{1.079} \mathrm{MnJT}^{3.601} \mathrm{MxJT}^{-2.566}$ & 37.9 & 13.6 \\
\hline & \multicolumn{3}{|c|}{ Region 2B: Western interior watersheds with mean elevations less than $3,000 \mathrm{ft}$} \\
\hline 2 & $Q=9.136$ AREA $^{0.9004} \mathrm{BS}_{0}^{0.4695} \mathrm{I}_{2} 0.8481$ & 32.6 & 2.0 \\
\hline 5 & $Q=14.54$ AREA $^{0.9042} \mathrm{BS}_{0}^{0.4735_{\mathrm{I}_{2}}}{ }^{0.7355}$ & 32.4 & 2.8 \\
\hline 10 & $Q=18.49$ AREA $^{0.9064} \mathrm{BS}_{0}^{0.4688_{\mathrm{I}_{2}}}{ }^{0.6937}$ & 33.0 & 3.6 \\
\hline 25 & $Q=23.72$ AREA $^{0.9086} \mathrm{BS}_{0}^{0.4615_{\mathrm{I}_{2}}{ }^{0}}{ }^{0.6578}$ & 34.1 & 4.8 \\
\hline 50 & $Q=27.75$ AREA $^{0.9101} \mathrm{BS}_{\mathrm{o}}^{0.4559_{\mathrm{I}_{2}}{ }^{2} 0.6390}$ & 35.1 & 5.5 \\
\hline 100 & $Q=31.85 \operatorname{AREA}^{0.9114} \mathrm{BS}_{\mathrm{o}}^{0.4501} \mathrm{I}_{2}{ }^{0.6252}$ & 36.2 & 6.2 \\
\hline 500 & $Q=41.72$ AREA $^{0.9141} \mathrm{BS}_{0}^{0.4365}{ }_{\mathrm{I}_{2}}^{2} 0.6059$ & 39.1 & 7.5 \\
\hline
\end{tabular}

${ }^{a}$ Equation: $Q$, peak flow, in $\mathrm{ft}^{3} \mathrm{sec}^{-1}$; AREA, drainage area, in $\mathrm{mi}^{2}$; $\mathrm{BS}_{\mathrm{o}}$, average basin slope, in degrees (fig. C. 15); $\mathrm{I}_{2}$, maximum precipitation intensity, 24-hour precipitation intensity, in inches, with a recurrence interval of 2 years (fig. C.14); MnJT, mean minimum January temperature, in degrees Fahrenheit (fig. C.16); MxJT, mean maximum January temperature, in degrees Fahrenheit (fig. C.17); SC, soil storage capacity, in inches (fig. C.18); SP, soil permeability, in inches per hour (fig. C.19)

${ }^{\mathrm{b}}$ Number of stations used in the regression analysis 
Table C.31-Exponent coefficients and description of hydrologic sub-regions for estimation of peak flow of ungaged sites near gaged sites on the same stream in South Dakota (Sando 1998). Flood-frequency relations at sites near gaged sites on the same stream can be estimated using a ratio of drainage area for the ungaged and gaged sites $\left(A_{u} / A_{g}\right)$ if the drainage area ratio is between 0.75 and 1.5 .

\begin{tabular}{|c|c|c|}
\hline Sub-region & Description & Exponent, $x$ \\
\hline A & $\begin{array}{l}\text { Minnesota-Red River Lowland, Coteau des Prairies, and eastern part of the } \\
\text { Southern Plateaus physical divisions of Flint (1955). }\end{array}$ & 0.529 \\
\hline B & $\begin{array}{l}\text { Lake Dakota Plain, James River Lowland and Highlands, and Coteau du } \\
\text { Missouri physical divisions of Flint (1955); part of the Coteau du Missouri } \\
\text { in central South Dakota that has topography typical of Great Plains "breaks" } \\
\text { sites was excluded from this sub-region. }\end{array}$ & 0.615 \\
\hline C & $\begin{array}{l}\text { Great Plains physiographic division of Fenneman (1946), excluding the } \\
\text { Sand Hills influenced area in south-central South Dakota, and areas with } \\
\text { topography typical of "breaks" sites, primarily in Cheyenne, Bad, and } \\
\text { White River basins. }\end{array}$ & 0.569 \\
\hline D & $\begin{array}{l}\text { Includes areas in the Great Plains physiographic division of Fenneman } \\
\text { (1946) with topography typical of "breaks" sites. }\end{array}$ & 0.545 \\
\hline $\mathrm{E}$ & Generally corresponds to the Sand Hills physical division of Flint (1955). & 0.691 \\
\hline $\mathrm{F}$ & $\begin{array}{l}\text { Generally corresponds to the northeast exterior part of the Black Hills } \\
\text { physical division of Flint (1955). }\end{array}$ & 0.654 \\
\hline G & $\begin{array}{l}\text { Generally corresponds to the southwest interior part of the Black Hills } \\
\text { physical division of Flint (1955). }\end{array}$ & 0.689 \\
\hline
\end{tabular}

Table C.32-Regional regression equations for South Dakota based on basin and climate characteristics (Sando 1998).

\begin{tabular}{|c|c|c|c|}
\hline $\begin{array}{l}\text { Recurrence } \\
\text { interval (yr) }\end{array}$ & Equation $^{\mathrm{a}}$ & $\begin{array}{c}\text { Average } \\
\text { standard error } \\
\text { of prediction (\%) }\end{array}$ & $\begin{array}{l}\text { Equival } \\
\text { years of re }\end{array}$ \\
\hline & Sub-region $A\left(n^{b}=55\right)$ & & \\
\hline 2 & $Q=30.9$ AREA $^{0.513} \mathrm{I}_{\mathrm{III}} 6.14$ & 59 & 4.5 \\
\hline 5 & $Q=85.5$ AREA $\left.^{0.509}\right|_{\text {II }} 5.45$ & 54 & 6.1 \\
\hline 10 & $Q=137 \operatorname{AREA}^{0.510} \mathrm{I}_{\mathrm{II}}^{11} 5.12$ & 54 & 7.8 \\
\hline 25 & $Q=218 \operatorname{AREA}^{0.513} \|^{4.80}$ & 56 & 9.8 \\
\hline 50 & $Q=287 \operatorname{AREA}^{\left.0.517\right|_{I I} 4.62}$ & 58 & 11.0 \\
\hline 100 & $Q=\left.362 \operatorname{AREA}^{0.521}\right|_{I I} 4.47$ & 61 & 11.9 \\
\hline \multirow[t]{2}{*}{500} & $Q=\left.553 \operatorname{AREA}^{0.531}\right|_{I I} 4.22$ & 69 & 13.0 \\
\hline & Sub-region $B(n=43)$ & & \\
\hline 2 & $Q=18.6$ AREA $^{0.425} \mathrm{I}_{\mathrm{II}}{ }^{1.10}$ & 67 & 5.4 \\
\hline 5 & $Q=51.6$ AREA $\left.^{0.508}\right|_{\text {III }} 0.835$ & 64 & 7.1 \\
\hline 10 & $Q=86.8$ AREA $\left.^{0.546}\right|_{\text {II }} 0.764$ & 67 & 8.7 \\
\hline 25 & $Q=148$ AREA $\left.^{0.584}\right|_{\text {II }} 0.730$ & 72 & 10.6 \\
\hline 50 & $Q=206$ AREA $\left.^{0.606}\right|_{I I} 0.728$ & 76 & 11.6 \\
\hline 100 & $Q=275$ AREA $\left.^{0.625}\right|_{\mathrm{II}} ^{0.742}$ & 81 & 12.4 \\
\hline \multirow[t]{2}{*}{500} & $Q=\left.480 \operatorname{AREA}^{0.661}\right|_{\mathrm{II}} 0.811$ & 93 & 13.6 \\
\hline & Sub-region C & & \\
\hline 2 & $Q=25.0 \operatorname{AREA}^{0.569}(n=48)$ & 108 & 1.8 \\
\hline 5 & $Q=72.5 \operatorname{AREA}^{0.578}(n=48)$ & 67 & 4.8 \\
\hline 10 & $Q=125 \operatorname{AREA}^{0.579}(\mathrm{n}=48)$ & 58 & 8.3 \\
\hline 25 & $Q=207 \operatorname{AREA}^{0.573}(n=46)$ & 53 & 12.0 \\
\hline 50 & $Q=286 \operatorname{AREA}^{0.570}(\mathrm{n}=46)$ & 53 & 14.9 \\
\hline 100 & $Q=379 \operatorname{AREA}^{0.566}(\mathrm{n}=46)$ & 55 & 16.5 \\
\hline 500 & $Q=664 \operatorname{AREA}^{0.556}(\mathrm{n}=46)$ & 65 & 16.6 \\
\hline
\end{tabular}




\begin{tabular}{|c|c|c|c|}
\hline $\begin{array}{l}\text { Recurrence } \\
\text { interval (yr) }\end{array}$ & Equation $^{a}$ & $\begin{array}{c}\text { Average } \\
\text { standard error } \\
\text { of prediction (\%) }\end{array}$ & $\begin{array}{c}\text { Equivalent } \\
\text { years of record }\end{array}$ \\
\hline & Sub-region $D\left(n^{b}=17\right)$ & & \\
\hline 2 & $Q=78.5$ AREA $^{0.357}$ & 109 & 2.3 \\
\hline 5 & $Q=230$ AREA $^{0.455}$ & 61 & 7.4 \\
\hline 10 & $Q=395$ AREA $^{0.515}$ & 44 & 17.9 \\
\hline 25 & $Q=676$ AREA $^{0.585}$ & 34 & 39.1 \\
\hline 50 & $Q=944$ AREA $^{0.627}$ & 33 & 52.5 \\
\hline 100 & $Q=1,270$ AREA $^{0.663}$ & 34 & 59.2 \\
\hline 500 & $Q=2,300$ AREA $^{0.732}$ & 41 & 57.5 \\
\hline & Sub-region $E(n=10)$ & & \\
\hline 2 & $Q=12.1 \mathrm{AREA}^{0.555}$ & 44 & 4.3 \\
\hline 5 & $Q=18.9 A R E A^{0.611}$ & 28 & 16.0 \\
\hline 10 & $Q=22.6$ AREA $^{0.653}$ & 26 & 27.0 \\
\hline 25 & $Q=27.0$ AREA $^{0.702}$ & 30 & 30.2 \\
\hline 50 & $Q=30.3$ AREA $^{0.737}$ & 36 & 27.4 \\
\hline 100 & $Q=33.6$ AREA $^{0.769}$ & 42 & 24.2 \\
\hline 500 & $Q=41.4 \mathrm{AREA}^{0.840}$ & 60 & 18.5 \\
\hline 2 & $\begin{array}{l}\text { Sub-region } \mathbf{F}(\mathbf{n}=\mathbf{1 7}) \\
Q=0.937 \mathrm{AREA} \mathrm{A}^{0.676} \mathrm{CS}^{0.447}\end{array}$ & & \\
\hline 5 & $Q=0.591$ AREA $^{0.779} \mathrm{CS}^{0.745}$ & $\begin{array}{r}107 \\
83\end{array}$ & $\begin{array}{l}2.6 \\
60\end{array}$ \\
\hline 10 & $Q=0.471$ AREA $^{0.832} \mathrm{CS}^{0.907}$ & $\begin{array}{l}03 \\
73\end{array}$ & $\begin{array}{r}0.0 \\
10.5\end{array}$ \\
\hline 25 & $Q=0.406$ AREA $^{0.888} \mathrm{CS}^{1.06}$ & 66 & 18.4 \\
\hline 50 & $Q=0.381 \mathrm{AREA}^{0.925} \mathrm{CS}^{1.16}$ & 64 & 24.6 \\
\hline 100 & $Q=0.352$ AREA $^{0.960} \mathrm{CS}^{1.25}$ & 64 & 29.4 \\
\hline 500 & $Q=0.243$ AREA $^{1.04} \mathrm{CS}^{1.47}$ & 78 & 31.2 \\
\hline & Sub-region $G\left(n^{b}=7\right)$ & & \\
\hline 2 & $Q=3.46$ AREA $^{0.650}$ & 51 & 3.9 \\
\hline 5 & $Q=7.70 \mathrm{AREA}^{0.654}$ & 71 & 3.2 \\
\hline 10 & $Q=11.3 \operatorname{AREA}^{0.673}$ & 87 & 3.2 \\
\hline 25 & $Q=16.5 \operatorname{AREA}^{0.704}$ & 108 & 3.3 \\
\hline 50 & $Q=21.0 \mathrm{AREA}^{0.731}$ & 126 & 3.3 \\
\hline 100 & $Q=25.8 A_{R E A} 0.759$ & 144 & 3.4 \\
\hline 500 & $Q=38.5 A R E A^{0.826}$ & 193 & 3.5 \\
\hline
\end{tabular}

${ }^{a}$ Equation: $Q$, peak flow, in $\mathrm{ft}^{3} \mathrm{sec}^{-1}$; AREA, drainage area, in $\mathrm{mi}^{2} ; \mathrm{I}_{\mathrm{II}}$, precipitation intensity index, 24-hour precipitation intensity, in inches, with a recurrence interval of 2 years (fig. C.21; estimated from U.S. Weather Bureau 1961)

${ }^{b}$ Number of stations used in the regression analysis

Table C.33-Exponent coefficients for estimation of peak flow of ungaged sites near gaged sites on the same stream in Utah (Kenney and others 2007). Flood-frequency relations at sites near gaged sites on the same stream can be estimated using a ratio of drainage area for the ungaged and gaged sites $\left(A_{u} / A_{g}\right)$ if the drainage area ratio is between 0.5 and 1.5 .

\begin{tabular}{cc}
\hline Hydrologic Region & Exponent, $\mathbf{x}$ \\
\hline 1 & 0.49 \\
2 & 0.51 \\
3 & 0.21 \\
4 & 0.84 \\
5 & 0.53 \\
6 & 0.31 \\
7 & 0.45 \\
\hline
\end{tabular}


Table C.34-Predictive regression equations and their associated uncertainty in estimating peak flows for natural streams in Utah (Kenney and others 2007).

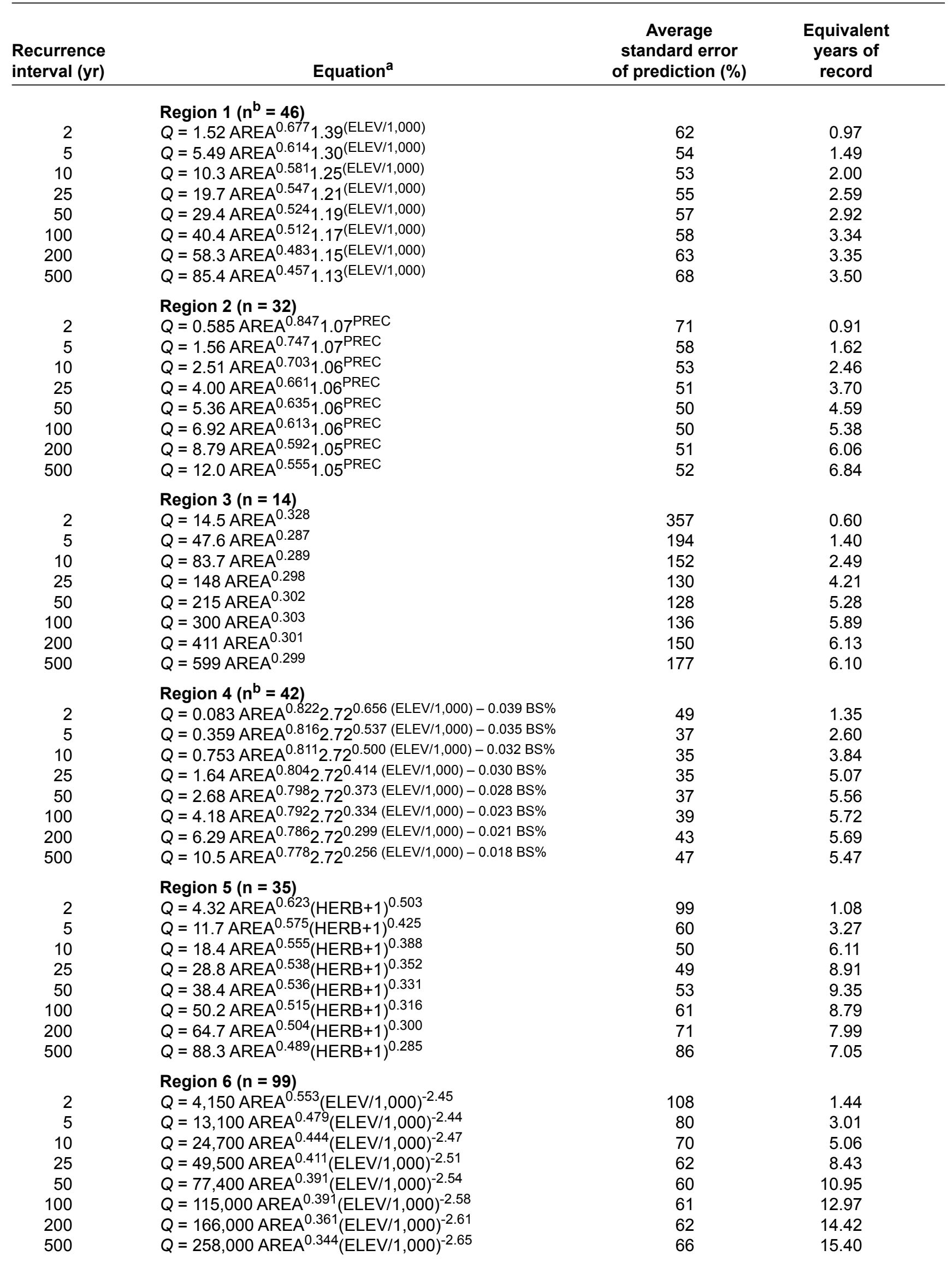


Table C.34-Continued.

\begin{tabular}{|c|c|c|c|}
\hline $\begin{array}{l}\text { Recurrence } \\
\text { interval (yr) }\end{array}$ & Equation $^{a}$ & $\begin{array}{c}\text { Average } \\
\text { standard error } \\
\text { of prediction (\%) }\end{array}$ & $\begin{array}{l}\text { Equivalent } \\
\text { years of } \\
\text { record }\end{array}$ \\
\hline 2 & $\begin{array}{l}\text { Region } 7\left(\mathbf{n}^{\mathbf{b}}=\mathbf{2 5}\right) \\
0=184 \mathrm{RF}\end{array}$ & & 271 \\
\hline $\begin{array}{l}2 \\
5\end{array}$ & $Q=67.4$ AREA $A^{0.539}$ & 95 & 2.46 \\
\hline 10 & $Q=134 \mathrm{AREA}^{0.487}$ & 110 & 2.62 \\
\hline 25 & $Q=278$ AREA $^{0.429}$ & 132 & 2.85 \\
\hline 50 & $Q=446$ AREA $^{0.390}$ & 149 & 2.99 \\
\hline 100 & $Q=683$ AREA $^{0.355}$ & 166 & 3.13 \\
\hline 200 & $Q=1,010$ AREA $^{0.321}$ & 185 & 3.23 \\
\hline 500 & $Q=1,620$ AREA $^{0.280}$ & 211 & 3.35 \\
\hline
\end{tabular}

a Equation: $Q$, peak flow, in $\mathrm{ft}^{3} \mathrm{sec}^{-1}$; AREA, drainage area, in $\mathrm{mi}^{2}$; ELEV, mean basin elevation, in $\mathrm{ft}$; PREC, mean annual precipitation, in inches; $\mathrm{BS}_{\%}$, average basin slope, in percent; HERB, area covered by herbaceous upland, in percent

${ }^{b}$ Number of stations used in the regression analysis

Table C.35-Exponent coefficients for estimation of peak flow of ungaged sites near gaged sites on the same stream in Washington (Knowles and Sumioka 2001; Sumioka and others 1998). Flood-frequency relations at sites near gaged sites on the same stream can be estimated using a ratio of drainage area for the ungaged and gaged sites $\left(A_{u} / A_{g}\right)$ if the drainage area ratio is between 0.5 and 1.5 .

Hydrologic Regions of Washington

\begin{tabular}{|c|c|c|c|c|c|c|c|c|c|}
\hline $\begin{array}{l}\text { Recurrence } \\
\text { interval (yr) }\end{array}$ & Region 1 & Region 2 & Region 3 & Region 4 & Region 5 & Region 6 & Region 7 & Region 8 & Region 9 \\
\hline 2 & 0.923 & 0.877 & 0.877 & 0.880 & 0.815 & 0.719 & 0.629 & 0.761 & 0.672 \\
\hline 10 & 0.921 & 0.868 & 0.875 & 0.856 & 0.787 & 0.716 & 0.587 & 0.706 & 0.597 \\
\hline 25 & 0.921 & 0.864 & 0.874 & 0.850 & 0.779 & 0.714 & 0.574 & 0.687 & 0.570 \\
\hline 50 & 0.921 & 0.862 & 0.872 & 0.845 & 0.774 & 0.713 & 0.566 & 0.676 & 0.553 \\
\hline 100 & 0.922 & 0.861 & 0.871 & 0.842 & 0.769 & 0.713 & 0.558 & 0.666 & 0.538 \\
\hline
\end{tabular}


Table C.36—Flood-peak flow regression equations and associated statistics for hydrologic regions in Washington (Knowles and Sumioka 2001; Sumioka and others 1998).

\begin{tabular}{|c|c|c|c|}
\hline $\begin{array}{l}\text { Recurrence } \\
\text { interval (yr) }\end{array}$ & Equation $^{a}$ & $\begin{array}{c}\text { Standard error } \\
\text { of prediction (\%) }\end{array}$ & $\begin{array}{l}\text { Equivalent years } \\
\text { of record }\end{array}$ \\
\hline $\begin{array}{r}2 \\
10 \\
25 \\
50 \\
100\end{array}$ & $\begin{array}{l}\text { Region } 1\left(\mathbf{n}^{\mathbf{b}}=\mathbf{6 1}\right) \\
Q=0.350 \text { AREA }^{0.923} \text { PREC }^{1.24} \\
Q=0.502 \text { AREA }^{0.921} \text { PREC }^{1.26} \\
Q=0.590 \text { AREA }^{0.921} \text { PREC }^{1.26} \\
Q=0.666 \text { AREA }^{0.921} \text { PREC }^{1.26} \\
Q=0.745 \text { AREA }^{0.922} \text { PREC }^{1.26}\end{array}$ & $\begin{array}{l}32 \\
33 \\
34 \\
36 \\
37\end{array}$ & $\begin{array}{l}1 \\
2 \\
3 \\
3 \\
4\end{array}$ \\
\hline $\begin{array}{r}2 \\
10 \\
25 \\
50 \\
100\end{array}$ & $\begin{array}{l}\text { Region } \mathbf{2}(\mathbf{n}=\mathbf{2 0 2}) \\
Q=0.090 \text { AREA } \\
Q=0.877 \text { PREC }^{1.51} \\
Q=0.148 \text { AREA }^{0.868} \text { PREC }^{1.8 .864} \text { PREC }^{1.59} \\
Q=0.161 \text { AREA }^{0.862} \text { PREC }^{1.61} \\
Q=0.174 \text { AREA }^{0.861} \text { PREC }^{1.62}\end{array}$ & $\begin{array}{l}56 \\
53 \\
53 \\
53 \\
54\end{array}$ & $\begin{array}{l}1 \\
1 \\
2 \\
2 \\
3\end{array}$ \\
\hline $\begin{array}{r}2 \\
10 \\
25 \\
50 \\
100\end{array}$ & $\begin{array}{l}\text { Region } 3(\mathbf{n}=\mathbf{6 3}) \\
Q=0.817 \text { AREA }^{0.877} \text { PREC }^{1.02} \\
Q=0.845 \text { AREA }^{0.875} \text { PREC }^{1.14} \\
Q=0.912 \text { AREA }^{0.874} \text { PREC }^{1.17} \\
Q=0.808 \text { AREA }^{0.872} \text { PREC }^{1.23} \\
Q=0.801 \text { AREA }^{0.871} \text { PREC }^{1.26}\end{array}$ & $\begin{array}{l}57 \\
55 \\
54 \\
54 \\
55\end{array}$ & $\begin{array}{l}1 \\
1 \\
2 \\
2 \\
3\end{array}$ \\
\hline $\begin{array}{r}2 \\
10 \\
25 \\
50 \\
100\end{array}$ & $\begin{array}{l}\text { Region } 4(\mathbf{n}=\mathbf{6 0}) \\
Q=0.025 \text { AREA } \\
Q=0.880 \text { PREC }^{1.70} \\
Q=0.179 \text { AREA } \\
Q=0.856 \text { PREC }^{1.37} \\
Q=0.505 \text { AREA }^{0.850} \text { PREC }^{0.845} \text { PREC }^{1.26} \\
Q=0.703 \text { AREA }^{0.842} \text { PREC }^{1.15}\end{array}$ & $\begin{array}{l}82 \\
84 \\
87 \\
90 \\
92\end{array}$ & $\begin{array}{l}1 \\
1 \\
1 \\
2 \\
2\end{array}$ \\
\hline $\begin{array}{r}2 \\
10 \\
25 \\
50 \\
100\end{array}$ & $\begin{array}{l}\text { Region } \mathbf{5}\left(\mathbf{n}^{\mathbf{b}}=\mathbf{1 9}\right) \\
Q=14.7 \text { AREA }^{0.815} \\
Q=35.2 \text { AREA }^{0.787} \\
Q=48.2 \text { AREA }^{0.779} \\
Q=59.1 \text { AREA }^{0.774} \\
Q=71.2 \text { AREA }^{0.769}\end{array}$ & $\begin{array}{l}96 \\
63 \\
56 \\
53 \\
52\end{array}$ & $\begin{array}{l}1 \\
2 \\
3 \\
5 \\
6\end{array}$ \\
\hline $\begin{array}{r}2 \\
10 \\
25 \\
50 \\
100\end{array}$ & $\begin{array}{l}\text { Region } \mathbf{6}(\mathbf{n}=\mathbf{2 3}) \\
Q=2.24 \mathrm{AREA}^{0.719} \mathrm{PREC}^{0.833} \\
Q=17.8 \mathrm{AREA}^{0.716} \mathrm{PREC}^{0.487} \\
Q=38.6 \mathrm{AREA}^{0.714} \mathrm{PREC}^{0.359} \\
Q=63.6 \mathrm{AREA}^{0.713} \mathrm{PREC}^{0.276} \\
Q=100 \mathrm{AREA}^{0.713} \mathrm{PREC}^{0.201}\end{array}$ & $\begin{array}{l}63 \\
69 \\
72 \\
74 \\
77\end{array}$ & $\begin{array}{l}1 \\
2 \\
2 \\
3 \\
3\end{array}$ \\
\hline $\begin{array}{r}2 \\
10 \\
25 \\
50 \\
100\end{array}$ & $\begin{array}{l}\text { Region } 7(\mathbf{n}=17) \\
Q=8.77 \text { AREA }^{0.629} \\
Q=50.9 \text { AREA }^{0.587} \\
Q=91.6 \text { AREA }^{0.574} \\
Q=131 \text { AREA }^{0.566} \\
Q=179 \text { AREA }^{0.558}\end{array}$ & $\begin{array}{r}128 \\
63 \\
54 \\
53 \\
56\end{array}$ & $\begin{array}{r}2 \\
7 \\
12 \\
15 \\
16\end{array}$ \\
\hline $\begin{array}{r}2 \\
10 \\
25 \\
50 \\
100\end{array}$ & $\begin{array}{l}\text { Region } \mathbf{8}(\mathbf{n}=\mathbf{2 3}) \\
Q=12.0 \text { AREA }^{0.761} \\
Q=32.6 \text { AREA }^{0.706} \\
Q=46.2 \text { AREA }^{0.687} \\
Q=57.3 \text { AREA }^{0.676} \\
Q=69.4 \text { AREA }^{0.666}\end{array}$ & $\begin{array}{l}133 \\
111 \\
114 \\
119 \\
126\end{array}$ & $\begin{array}{r}<1 \\
1 \\
1 \\
1 \\
1\end{array}$ \\
\hline $\begin{array}{r}2 \\
10 \\
25 \\
50 \\
100\end{array}$ & $\begin{array}{l}\text { Region } 9\left(\mathbf{n}^{\mathbf{b}}=\mathbf{3 6}\right) \\
Q=0.803 \text { AREA }^{0.672} \text { PREC }^{1.16} \\
Q=15.4 \text { AREA }^{0.597} \mathrm{PREC}^{0.662} \\
Q=41.1 \text { AREA }^{0.570} \text { PREC }^{0.508} \\
Q=74.7 \text { AREA }^{0.553} \mathrm{PREC}^{0.420} \\
Q=126 \text { AREA }^{0.538} \text { PREC }^{0.344}\end{array}$ & $\begin{array}{l}80 \\
57 \\
55 \\
55 \\
56\end{array}$ & $\begin{array}{r}2 \\
6 \\
8 \\
10 \\
12\end{array}$ \\
\hline
\end{tabular}

a Equation: $Q$, peak flow, in $\mathrm{ft}^{3} \mathrm{sec}^{-1}$; AREA, drainage area, in $\mathrm{mi}^{2}$; PREC, mean annual precipitation, in inches

${ }^{b}$ Number of stations used in the regression analysis 
Table C.37-Exponent coefficients for estimation of peak flow of ungaged sites near gaged sites on the same stream in Wyoming (Miller 2003). Flood-frequency relations at sites near gaged sites on the same stream can be estimated using a ratio of drainage area for the ungaged and gaged sites $\left(A_{u} / A_{q}\right)$ if the drainage area ratio is between 0.75 and 1.5 .

Hydrologic Regions of Wyoming

\begin{tabular}{ccccccc} 
Recurrence & $\begin{array}{c}\text { Region 1 } \\
\text { Rocky } \\
\text { interval (yr) }\end{array}$ & $\begin{array}{c}\text { Region 2 } \\
\text { Central } \\
\text { Basins and } \\
\text { Northern } \\
\text { Plains }\end{array}$ & $\begin{array}{c}\text { Region 3 } \\
\text { Eastern } \\
\text { Basins and } \\
\text { Eastern } \\
\text { Plains }\end{array}$ & $\begin{array}{c}\text { Region 4 } \\
\text { Eastern } \\
\text { Mountains }\end{array}$ & $\begin{array}{c}\text { Region 5 } \\
\text { Overthrust } \\
\text { Belt }\end{array}$ & $\begin{array}{c}\text { Region 6 } \\
\text { High } \\
\text { Desert }\end{array}$ \\
\hline 1.5 & 0.885 & 0.486 & 0.401 & 0.518 & 0.871 & 0.626 \\
2 & 0.866 & 0.475 & 0.402 & 0.506 & 0.869 & 0.608 \\
2.33 & 0.858 & 0.470 & 0.403 & 0.503 & 0.868 & 0.600 \\
5 & 0.829 & 0.455 & 0.407 & 0.506 & 0.864 & 0.567 \\
10 & 0.810 & 0.447 & 0.410 & 0.518 & 0.861 & 0.544 \\
25 & 0.790 & 0.439 & 0.416 & 0.536 & 0.857 & 0.520 \\
50 & 0.776 & 0.434 & 0.423 & 0.549 & 0.853 & 0.504 \\
100 & 0.764 & 0.430 & 0.432 & 0.562 & 0.850 & 0.489 \\
200 & 0.752 & 0.427 & 0.441 & 0.573 & 0.847 & 0.476 \\
500 & 0.738 & 0.425 & 0.454 & 0.585 & 0.842 & 0.459 \\
\hline
\end{tabular}


Table C.38-Regression equations for Wyoming based on basin characteristics (Miller 2003).

\begin{tabular}{|c|c|c|c|c|}
\hline $\begin{array}{l}\text { Recurrence } \\
\text { interval (yr) }\end{array}$ & & Equation $^{a}$ & $\begin{array}{c}\text { Average } \\
\text { standard error } \\
\text { of prediction (\%) }\end{array}$ & $\begin{array}{c}\text { Equivale } \\
\text { years } \\
\text { of recorc }\end{array}$ \\
\hline & \multicolumn{4}{|c|}{ Rocky Mountains (Region 1) } \\
\hline 1.5 & $Q=0.126$ AREA $^{0.885}$ & $\left(\frac{E L E V-3,000}{1,000}\right)^{2.56}(\text { LONG-100 })^{0.032}$ & 56 & 1.0 \\
\hline 2 & $Q=0.313 A R E A^{0.866}$ & $\left(\frac{E L E V-3,000}{1,000}\right)^{2.32}(\text { LONG-100) })^{-0.069}$ & 50 & 1.2 \\
\hline 2.33 & $Q=0.458$ AREA $^{0.858}$ & $\left(\frac{E L E V-3,000}{1,000}\right)^{2.22}(\text { LONG-100) })^{-0.110}$ & 47 & 1.3 \\
\hline 5 & $Q=1.89 \operatorname{AREA}^{0.829}$ & $\left(\frac{E L E V-3,000}{1,000}\right)^{1.85}(\text { LONG-100 })^{-0.262}$ & 39 & 2.4 \\
\hline 10 & $Q=4.71 \mathrm{AREA}^{0.810}$ & $\left(\frac{E L E V-3,000}{1,000}\right)^{1.60}(\text { LONG-100) })^{-0.357}$ & 36 & 3.8 \\
\hline 25 & $Q=12.1 \operatorname{AREA}^{0.790}$ & $\left(\frac{E L E V-3,000}{1,000}\right)^{1.34}(\text { LONG-100) })^{-0.451}$ & 35 & 5.4 \\
\hline 50 & $Q=22.3 \operatorname{AREA}^{0.776}$ & $\left(\frac{E L E V-3,000}{1,000}\right)^{1.16}(\text { LONG-100) })^{-0.510}$ & 36 & 6.3 \\
\hline 100 & $Q=38.6$ AREA $^{0.764}$ & $\left(\frac{E L E V-3,000}{1,000}\right)^{1.00}(\text { LONG-100) })^{-0.562}$ & 38 & 6.9 \\
\hline 200 & $Q=64.3 \operatorname{AREA}^{0.752}$ & $\left(\frac{E L E V-3,000}{1,000}\right)^{0.857} \quad(\text { LONG-100) })^{-0.611}$ & 40 & 7.2 \\
\hline \multirow[t]{2}{*}{500} & $Q=120$ AREA $^{0.738}$ & $\left(\frac{E L E V-3,000}{1,000}\right)^{0.674}($ LONG-100)-0.670 & 43 & 7.3 \\
\hline & \multicolumn{4}{|c|}{ Central Basins and Northern Plains (Hydrologic Region 2 in Wyoming) } \\
\hline 1.5 & $Q=17.8$ AREA $^{0.486}$ & & 135 & 1.4 \\
\hline 2 & $Q=29.9$ AREA $^{0.475}$ & & 113 & 1.6 \\
\hline 2.33 & $Q=37.1$ AREA $^{0.470}$ & & 105 & 1.7 \\
\hline 5 & $Q=80.9$ AREA $^{0.455}$ & & 81 & 3.4 \\
\hline 10 & $Q=134$ AREA $^{0.447}$ & & 69 & 5.9 \\
\hline 25 & $Q=225$ AREA $^{0.439}$ & & 60 & 10.4 \\
\hline 50 & $Q=311 \mathrm{AREA}^{0.434}$ & & 57 & 13.9 \\
\hline 100 & $Q=415$ AREA $^{0.430}$ & & 56 & 16.9 \\
\hline 200 & $Q=536$ AREA $^{0.427}$ & & 57 & 19.0 \\
\hline 500 & $Q=728$ AREA $^{0.425}$ & & 61 & 20.1 \\
\hline & \multicolumn{4}{|c|}{ Eastern Basins and Eastern Plains (Hydrologic Region 3 in Wyoming) } \\
\hline 1.5 & $Q=1.12$ AREA $^{0.401} \mathrm{~S}$ & $\mathrm{SHI}$ & 127 & 2.0 \\
\hline 2 & $Q=2.28 A R E A^{0.402} S$ & $\mathrm{SHI}^{2.90}$ & 98 & 2.6 \\
\hline 2.33 & $Q=3.10 \operatorname{AREA}^{0.403} \mathrm{~S}$ & $\mathrm{SHI}^{2.84}$ & 89 & 3.1 \\
\hline 5 & $Q=10.1 \mathrm{AREA}^{0.407} \mathrm{~S}$ & $\mathrm{SH}^{2.60}$ & 61 & 7.7 \\
\hline 10 & $Q=21.9 \operatorname{AREA}^{0.410} \mathrm{~S}$ & $\mathrm{SHI}^{2.44}$ & 51 & 14.4 \\
\hline 25 & $Q=48.8 \mathrm{AREA}^{0.416} \mathrm{~S}$ & $\mathrm{SHI}^{2.27}$ & 46 & 23.6 \\
\hline 50 & $Q=80.9$ AREA $^{0.423} S$ & $\mathrm{SHI} \mathrm{I}^{2.16}$ & 48 & 28.0 \\
\hline 100 & $Q=127 \mathrm{AREA}^{0.432} \mathrm{SI}$ & $\mathrm{HI}^{2.05}$ & 51 & 29.5 \\
\hline 200 & $Q=193 \mathrm{AREA}^{0.441} \mathrm{~S}$ & $\mathrm{SHI} \mathbf{1}^{1.94}$ & 56 & 28.9 \\
\hline 500 & $Q=323$ AREA $^{0.454} S$ & $3 \mathrm{HI}^{1.80}$ & 66 & 26.6 \\
\hline
\end{tabular}




\begin{tabular}{|c|c|c|c|}
\hline $\begin{array}{l}\text { Recurrence } \\
\text { interval (yr) }\end{array}$ & Equation $^{\mathrm{a}}$ & $\begin{array}{c}\text { Average } \\
\text { standard error } \\
\text { of prediction (\%) }\end{array}$ & $\begin{array}{c}\text { Equivalent } \\
\text { years } \\
\text { of record } \\
\end{array}$ \\
\hline & Eastern Mountains (Hydrologic Region 4 in Wyoming) & & \\
\hline 1.5 & $Q=4.27$ AREA $^{0.518}$ MAR $^{1.42}(\text { LAT- } 40)^{-0.435}$ & 53 & 3.4 \\
\hline 2 & $Q=6.26$ AREA $^{0.506}$ MAR $^{1.33}(\text { LAT- } 40)^{-0.315}$ & 53 & 3.2 \\
\hline 2.33 & $Q=7.27$ AREA $^{0.503}$ MAR $^{1.30}(\text { LAT-40) })^{-0.262}$ & 53 & 3.3 \\
\hline 5 & $Q=12.2$ AREA $^{0.506}$ MAR $^{1.19}(\text { LAT- } 40)^{-0.048}$ & 53 & 4.6 \\
\hline 10 & $Q=16.9$ AREA $^{0.518}$ MAR $^{1.12}(\text { LAT-40) })^{0.107}$ & 54 & 6.3 \\
\hline 25 & $Q=23.5$ AREA $^{0.536} \mathrm{MAR}^{1.05}(\text { LAT-40) })^{0.283}$ & 54 & 8.9 \\
\hline 50 & $Q=29.1$ AREA $^{0.549}$ MAR $^{1.01}(\text { LAT-40) })^{0.403}$ & 54 & 11.0 \\
\hline 100 & $Q=35.3$ AREA $^{0.562}$ MAR $^{0.963}(\text { LAT- }-40)^{0.517}$ & 54 & 13.1 \\
\hline 200 & $Q=42.2$ AREA $^{0.573}$ MAR $^{0.922}(\text { LAT-40 })^{0.626}$ & 55 & 15.1 \\
\hline \multirow[t]{2}{*}{500} & $Q=52.5$ AREA $^{0.585} \mathrm{MAR}^{0.873}(\text { LAT-40 })^{0.766}$ & 56 & 17.5 \\
\hline & Overthrust Belt (Hydrologic Region 5 in Wyoming) & & \\
\hline 1.5 & $Q=2.08$ AREA $^{0.871} \mathrm{JAN}^{1.02}$ & 63 & 0.8 \\
\hline 2 & $Q=3.07$ AREA $^{0.869} \mathrm{JAN}^{0.884}$ & 61 & 0.7 \\
\hline 2.33 & $Q=3.58$ AREA $^{0.868} \mathrm{JAN}^{0.831}$ & 61 & 0.6 \\
\hline 5 & $Q=6.19$ AREA $^{0.864} \mathrm{JAN}^{0.643}$ & 61 & 0.8 \\
\hline 10 & $Q=8.71$ AREA $^{0.861} \mathrm{JAN}^{0.529}$ & 62 & 1.0 \\
\hline 25 & $Q=12.3$ AREA $^{0.857} \mathrm{JAN}^{0.415}$ & 64 & 1.2 \\
\hline 50 & $Q=15.2$ AREA $^{0.853} \mathrm{JAN}^{0.346}$ & 66 & 1.4 \\
\hline 100 & $Q=18.3$ AREA $^{0.850} \mathrm{JAN}^{0.287}$ & 68 & 1.6 \\
\hline 200 & $Q=21.6$ AREA $^{0.847} \mathrm{JAN}^{0.235}$ & 69 & 1.7 \\
\hline \multirow[t]{2}{*}{500} & $Q=26.2$ AREA $^{0.842} \mathrm{JAN}^{0.176}$ & 72 & 1.9 \\
\hline & High Desert (Hydrologic Region 6 in Wyoming) & & \\
\hline 1.5 & $Q=12.7$ AREA $^{0.626}\left(\text { LAT }^{-40}\right)^{-1.18}$ & 72 & 3.2 \\
\hline 2 & $Q=22.2$ AREA $^{0.608}(\text { LAT- } 40)^{-1.24}$ & 66 & 3.2 \\
\hline 2.33 & $Q=28.1$ AREA $^{0.600}(\text { LAT }-40)^{-1.26}$ & 64 & 3.3 \\
\hline 5 & $Q=66.4 \operatorname{AREA}^{0.567}(\text { LAT- } 40)^{-1.35}$ & 59 & 4.7 \\
\hline 10 & $Q=116 \operatorname{AREA}^{0.544}(\text { LAT- } 40)^{-1.40}$ & 57 & 6.4 \\
\hline 25 & $Q=204$ AREA $^{0.520}(\text { LAT-40 })^{-1.44}$ & 58 & 8.5 \\
\hline 50 & $Q=290$ AREA $^{0.504}(\text { LAT- } 40)^{-1.46}$ & 60 & 9.7 \\
\hline 100 & $Q=394$ AREA $^{0.489}(\text { LAT-40 })^{-1.47}$ & 63 & 10.4 \\
\hline 200 & $Q=519$ AREA $^{0.476}(\text { LAT-40 })^{-1.48}$ & 67 & 10.9 \\
\hline 500 & $Q=719$ AREA $^{0.459}(\text { LAT- } 40)^{-1.49}$ & 73 & 11.1 \\
\hline
\end{tabular}

${ }^{a}$ Equation: $Q$, peak flow, in $\mathrm{ft}^{3} \mathrm{sec}^{-1}$; AREA, drainage area, in $\mathrm{mi}^{2}$; ELEV, mean basin elevation, in $\mathrm{ft}$; LONG, longitude of basin outlet location, in decimal degrees; LAT, latitude of basin outlet location, in decimal degrees; SHI, mean basin Soils Hydrologic Index (fig. C.26), unitless; JAN, mean January precipitation, in inches; MAR, mean March precipitation, in inches 


\section{Appendix D—NRCS Curve Number Method}

The curve number method was developed by the U.S. Department of Agriculture Natural Resources Conservation Service (NRCS), formerly the Soil Conservation Service (SCS), to estimate runoff and peak flow. The following steps were modified from SCS Engineering Field Handbook: Chapter 2-Estimating Runoff (USDA SCS 1991) and used to apply the NRCS curve number method for estimation of post-fire peak flow.

1. Determine rainfall type among type I, IA, II, and III (fig. 4) and design storm recurrence interval (e.g., 2-, 5-, 10-, 25-, 50-, and 100-year), based on the location of the watershed. The rainfall amount $(\mathrm{P})$ is determined using NOAA Atlas (NOAA 2008).

2. Classify the watershed soil among soil groups (A, B, C, and D) (table 14).

3. Determine the average watershed slope, which is the slope of the land, not the water course. The following relationship can be used, or any adequate method can be used:

$$
Y=\frac{100 C I}{A}
$$

Where:

$$
\begin{aligned}
Y & =\text { average watershed slope in percent } \\
C & =\text { total contour length in feet } \\
I & =\text { contour interval in feet } \\
A & =\text { drainage area in square feet }
\end{aligned}
$$

4. Determine the runoff curve number $(\mathrm{CN})$, based on cover type, treatment, hydrologic conditions, and hydrologic soil group determined above (table D.2; table D.3; fig. D.1). A representative curve number for a watershed can be estimated by area weighting with different curve numbers.

5. Estimate time of concentration using the following empirical relationship:

$$
T_{c}=\frac{\left[\left(\frac{1000}{C N}\right)-9\right]^{0.7}}{1140 Y^{0.5}}
$$

Where:

$$
\begin{aligned}
T_{c} & =\text { time of concentration in hours } \\
l & =\text { flow length in feet } \\
C N & =\text { runoff curve number } \\
Y & =\text { average watershed slope in percent }
\end{aligned}
$$


6. Calculate potential maximum retention after runoff begins, in inches (S), using the following relationship:

$$
S=\frac{1000}{C N}-10
$$

7. Calculate the runoff $(\mathrm{Q})$ in inches, with a given total rainfall amount $(\mathrm{P})$ in inches, and the S-value calculated above using figure D.2 or the following relationship:

$$
Q=\frac{(P-0.2 S)^{2}}{P+0.8 S}
$$

8. Calculate initial abstraction $\left(\mathrm{I}_{\mathrm{a}}\right)$ in inches, which includes the portion of the rainfall that is not available for either infiltration or runoff and is used to wet surfaces prior to reaching the ground (interception). The initial abstraction is generally returned to the atmosphere by evaporation (Chin 2000). The initial abstraction is found to be approximated by table D.4 or the following equation:

$$
\mathrm{I}_{\mathrm{a}}=0.2 \mathrm{~S}
$$

9. Calculate $\mathrm{I}_{\mathrm{a}} / \mathrm{P}$ using the values determined above.

10. Determine unit peak flow $\left(\mathrm{q}_{\mathrm{u}}\right)$ in cfs/acre/inch, using $\mathrm{T}_{\mathrm{c}}$ and $\mathrm{I}_{\mathrm{a}} / \mathrm{P}$ in figure D.3 to D.6.

11. Estimate peak flow $\left(\mathrm{q}_{\mathrm{p}}\right)$ using the following relationship:

$$
q_{p}=\frac{q_{u} \times A \times Q}{43,560}
$$

Where:

$$
\begin{aligned}
q_{p} & =\text { peak flow in cfs } \\
q_{u} & =\text { unit peak flow in cfs/ac/in } \\
A & =\text { drainage area in square feet } \\
Q & =\text { runoff in inches }
\end{aligned}
$$

Limitations and notations for using the NRCS curve number method are as follows:

- This method only considers rainfall-generated runoff, and not runoff generated from snowmelt. Runoff and peak flow from snowmelt or rain on frozen ground cannot be estimated.

- The watershed drainage area must be greater than 1.0 acre and less than 2,000 acres $\left(3.1 \mathrm{mi}^{2}\right)$.

- The watershed must be hydrologically similar; i.e., able to represented by a weighted $\mathrm{CN}$. Land use, soils, and cover are distributed uniformly throughout the watershed. The land use must be primarily rural. The NRCS curve number method is not applicable if urban conditions represent more than 10 percent of the watershed.

- The computed time of concentration $\left(\mathrm{T}_{\mathrm{c}}\right)$ should be less than 10 hours. If the computed $\mathrm{T}_{\mathrm{c}}$ is less than 0.1 hour, 0.1 hour is used. 
- The flow length $(l)$ should be greater than $200 \mathrm{ft}$ and less than $26,000 \mathrm{ft}$.

- Potholes (storage) should be less than one third of the total drainage area and should not intercept the drainage.

- The average watershed slope should be greater than 0.5 percent and less than 64 percent.

- The weighted CN should be greater than 40 and less than 98 .

- If $\mathrm{I}_{\mathrm{a}} / \mathrm{P}$ is less than $0.1,0.1$ is used; if $\mathrm{I}_{\mathrm{a}} / \mathrm{P}$ is greater than $0.5,0.5$ is used.

Table D.1-Runoff depth for selected CN/s and rainfall amounts ${ }^{\mathrm{a}}$ (USDA SCS 1991).

\begin{tabular}{|c|c|c|c|c|c|c|c|c|c|c|c|c|}
\hline \multirow[b]{2}{*}{ Rainfall } & \multicolumn{12}{|c|}{ Runoff $(Q)$ for curve number of } \\
\hline & 40 & 45 & 50 & 55 & 60 & 65 & 70 & 75 & 80 & 85 & 90 & 95 \\
\hline \multicolumn{13}{|c|}{ 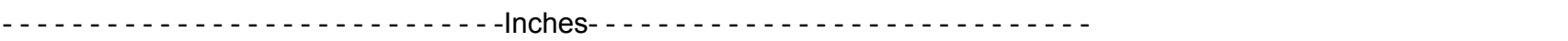 } \\
\hline 1.0 & 0.00 & 0.00 & 0.00 & 0.00 & 0.00 & 0.00 & 0.00 & 0.03 & 0.08 & 0.17 & 0.32 & 0.56 \\
\hline 1.2 & .00 & .00 & .00 & .00 & .00 & .00 & .03 & .07 & .15 & .27 & .46 & .74 \\
\hline 1.4 & .00 & .00 & .00 & .00 & .00 & .02 & .06 & .13 & .24 & .39 & .61 & .92 \\
\hline 1.6 & .00 & .00 & .00 & .00 & .01 & .05 & .11 & .20 & .34 & .52 & .76 & 1.11 \\
\hline 1.8 & .00 & .00 & .00 & .00 & .03 & .09 & .17 & .29 & .44 & .65 & .93 & 1.29 \\
\hline 2.0 & .00 & .00 & .00 & .02 & .06 & .14 & .24 & .38 & .56 & .80 & 1.09 & 1.48 \\
\hline 2.5 & .00 & .00 & .02 & .08 & .17 & .30 & .46 & .65 & .89 & 1.18 & 1.53 & 1.96 \\
\hline 3.0 & .00 & .02 & .09 & .19 & .33 & .51 & .71 & .96 & 1.25 & 1.59 & 1.98 & 2.45 \\
\hline 3.5 & .02 & .08 & .20 & .35 & .53 & .75 & 1.01 & 1.30 & 1.64 & 2.02 & 2.45 & 2.94 \\
\hline 4.0 & .06 & .18 & .33 & .53 & .76 & 1.03 & 1.33 & 1.67 & 2.04 & 2.46 & 2.92 & 3.43 \\
\hline 4.5 & .14 & .30 & .50 & .74 & 1.02 & 1.33 & 1.67 & 2.05 & 2.46 & 2.91 & 3.40 & 3.92 \\
\hline 5.0 & .24 & .44 & .69 & .98 & 1.30 & 1.65 & 2.04 & 2.45 & 2.89 & 3.37 & 3.88 & 4.42 \\
\hline 6.0 & .50 & .80 & 1.14 & 1.52 & 1.92 & 2.35 & 2.81 & 3.28 & 3.78 & 4.30 & 4.85 & 5.41 \\
\hline 7.0 & .84 & 1.24 & 1.68 & 2.12 & 2.60 & 3.10 & 3.62 & 4.15 & 4.69 & 5.25 & 5.82 & 6.41 \\
\hline 8.0 & 1.25 & 1.74 & 2.25 & 2.78 & 3.33 & 3.89 & 4.46 & 5.04 & 5.63 & 6.21 & 6.81 & 7.40 \\
\hline 9.0 & 1.71 & 2.29 & 2.88 & 3.49 & 4.10 & 4.72 & 5.33 & 5.95 & 6.57 & 7.18 & 7.79 & 8.40 \\
\hline 10.0 & 2.23 & 2.89 & 3.56 & 4.23 & 4.90 & 5.56 & 6.22 & 6.88 & 7.52 & 8.16 & 8.78 & 9.40 \\
\hline 11.0 & 2.78 & 3.52 & 4.26 & 5.00 & 5.72 & 6.43 & 7.13 & 7.81 & 8.48 & 9.13 & 9.77 & 10.39 \\
\hline 12.0 & 3.38 & 4.19 & 5.00 & 5.79 & 6.56 & 7.32 & 8.05 & 8.76 & 9.45 & 10.11 & 10.76 & 11.39 \\
\hline 13.0 & 4.00 & 4.89 & 5.76 & 6.61 & 7.42 & 8.21 & 8.98 & 9.71 & 10.42 & 11.10 & 11.76 & 12.39 \\
\hline 14.0 & 4.65 & 5.62 & 6.55 & 7.44 & 8.30 & 9.12 & 9.91 & 10.67 & 11.39 & 12.08 & 12.75 & 13.39 \\
\hline 15.0 & 5.33 & 6.36 & 7.35 & 8.29 & 9.19 & 10.04 & 10.85 & 11.63 & 12.37 & 13.07 & 13.74 & 14.39 \\
\hline
\end{tabular}

a Interpolate the values shown to obtain runoff depths for CN's or rainfall amounts not shown. 
Table D.2-Runoff curve numbers for other agricultural lands ${ }^{a}$ (USDA SCS 1991).

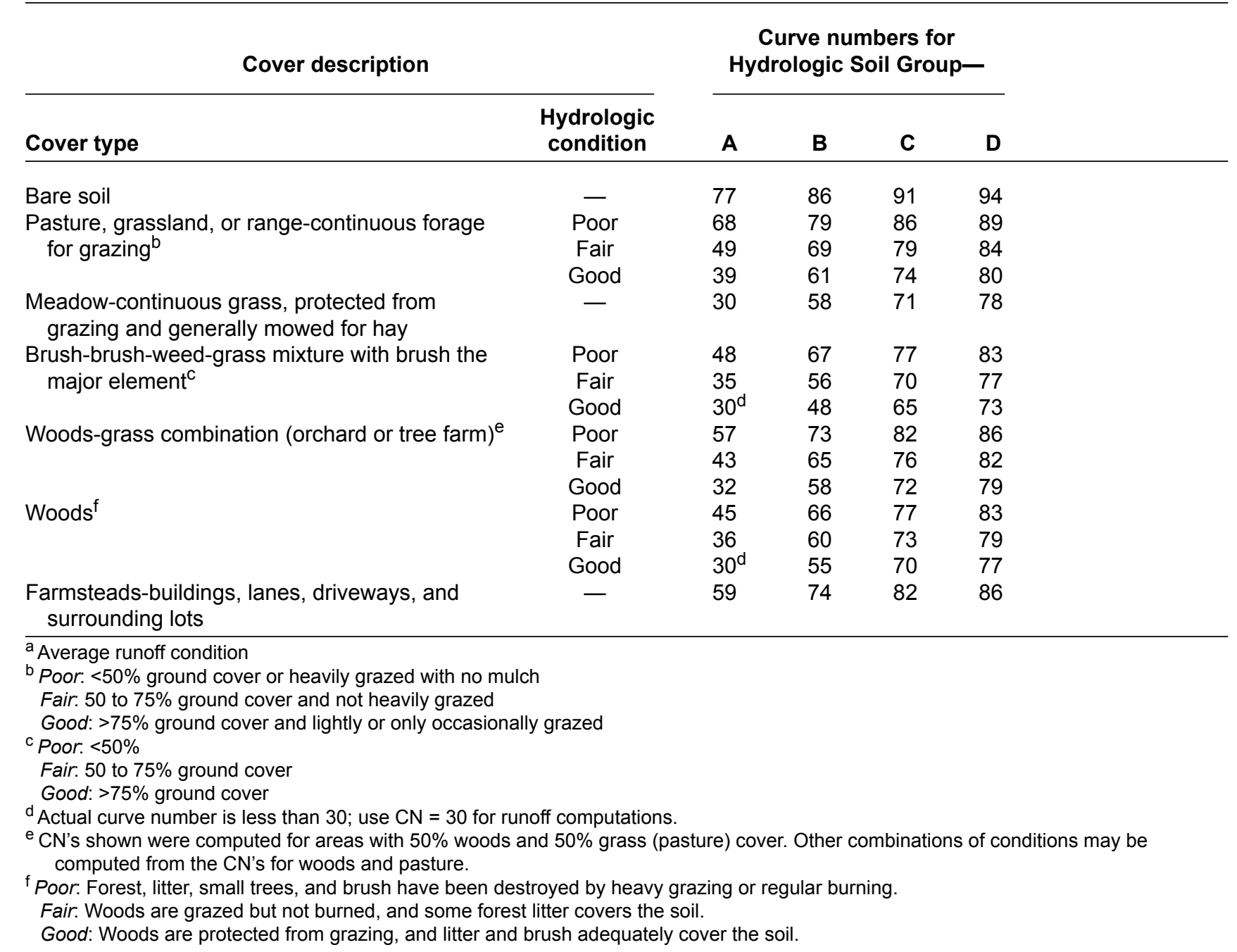


Table D.3-Runoff curve numbers for arid and semiarid rangelands ${ }^{a}$ (USDA SCS 1991).

\begin{tabular}{|c|c|c|c|c|}
\hline \multicolumn{3}{|c|}{ Cover description } & \multicolumn{2}{|c|}{$\begin{array}{l}\text { Curve nu } \\
\text { Hydrologic }\end{array}$} \\
\hline \multicolumn{2}{|l|}{ Cover type } & $\begin{array}{l}\text { Hydrologic } \\
\text { Condition }\end{array}$ & $A^{c}$ & B \\
\hline \multicolumn{2}{|c|}{$\begin{array}{l}\text { Herbaceous-mixture of grass, weeds, and low-growing brush, } \\
\text { with brush the minor element }\end{array}$} & $\begin{array}{l}\text { Poor } \\
\text { Fair } \\
\text { Good }\end{array}$ & & $\begin{array}{l}80 \\
71 \\
62\end{array}$ \\
\hline \multicolumn{2}{|c|}{$\begin{array}{l}\text { Oak-aspen-mountain brush mixture of oak brush, aspen, } \\
\text { mountain mahogany, bitter brush, maple, and other brush }\end{array}$} & $\begin{array}{l}\text { Poor } \\
\text { Fair } \\
\text { Good }\end{array}$ & & $\begin{array}{l}66 \\
48 \\
30\end{array}$ \\
\hline \multicolumn{2}{|c|}{ Pinyon-juniper-pinyon, juniper, or both; grass understory } & $\begin{array}{l}\text { Poor } \\
\text { Fair } \\
\text { Good }\end{array}$ & & $\begin{array}{l}75 \\
58 \\
41\end{array}$ \\
\hline \multicolumn{2}{|l|}{ Sagebrush with grass understory } & $\begin{array}{l}\text { Poor } \\
\text { Fair } \\
\text { Good }\end{array}$ & & $\begin{array}{l}67 \\
51 \\
35\end{array}$ \\
\hline \multicolumn{2}{|c|}{$\begin{array}{l}\text { Desert shrub-major plants include saltbush greasewood, } \\
\text { creosotebush, blackbrush, bursage, palo verde, mesquite, } \\
\text { and cactus }\end{array}$} & $\begin{array}{l}\text { Poor } \\
\text { Fair } \\
\text { Good }\end{array}$ & $\begin{array}{l}63 \\
55 \\
49\end{array}$ & $\begin{array}{l}77 \\
72 \\
68\end{array}$ \\
\hline \multicolumn{5}{|c|}{$\begin{array}{l}\text { a Average runoff condition. For rangelands in humid regions, use table } \\
\text { b Poor: }<30 \% \text { ground cover (litter, grass, and brush overstory) } \\
\text { Fair: } 30 \text { to } 70 \% \text { ground cover } \\
\text { Good: }>70 \% \text { ground cover } \\
{ }^{c} \text { Curve numbers for group A were developed only for desert shrub. }\end{array}$} \\
\hline \multirow[t]{2}{*}{ Curve number } & $\mathbf{I}_{\mathbf{a}}$ & Curve number & \multicolumn{2}{|l|}{$\mathbf{I}_{\mathbf{a}}$} \\
\hline & (inch) & & \multicolumn{2}{|l|}{ (inch) } \\
\hline 40 & 3.000 & 68 & \multicolumn{2}{|l|}{0.941} \\
\hline 41 & 2.878 & 69 & \multicolumn{2}{|l|}{0.899} \\
\hline 42 & 2.762 & 70 & \multicolumn{2}{|l|}{0.857} \\
\hline 43 & 2.651 & 71 & \multicolumn{2}{|l|}{0.817} \\
\hline 44 & 2.545 & 72 & \multicolumn{2}{|l|}{0.778} \\
\hline 45 & 2.444 & 73 & \multicolumn{2}{|l|}{0.740} \\
\hline 46 & 2.348 & 74 & \multicolumn{2}{|l|}{0.703} \\
\hline 47 & 2.255 & 75 & \multicolumn{2}{|l|}{0.667} \\
\hline 48 & 2.167 & 76 & \multicolumn{2}{|l|}{0.632} \\
\hline 49 & 2.082 & 77 & \multicolumn{2}{|l|}{0.597} \\
\hline 50 & 2.000 & 78 & \multicolumn{2}{|l|}{0.564} \\
\hline 51 & 1.922 & 79 & \multicolumn{2}{|l|}{0.532} \\
\hline 52 & 1.846 & 80 & \multicolumn{2}{|l|}{0.500} \\
\hline 53 & 1.774 & 81 & \multicolumn{2}{|l|}{0.469} \\
\hline 54 & 1.704 & 82 & \multicolumn{2}{|l|}{0.439} \\
\hline 55 & 1.636 & 83 & \multicolumn{2}{|l|}{0.410} \\
\hline 56 & 1.571 & 84 & 0.381 & \\
\hline 57 & 1.509 & 85 & 0.353 & \\
\hline 58 & 1.448 & 86 & 0.326 & \\
\hline 59 & 1.390 & 87 & 0.299 & \\
\hline 60 & 1.333 & 88 & 0.273 & \\
\hline 61 & 1.279 & 89 & 0.247 & \\
\hline 62 & 1.226 & 90 & 0.222 & \\
\hline 63 & 1.175 & 91 & 0.198 & \\
\hline 64 & 1.125 & 92 & 0.174 & \\
\hline 65 & 1.077 & 93 & 0.151 & \\
\hline 66 & 1.030 & 94 & 0.128 & \\
\hline 67 & 0.985 & 95 & 0.105 & \\
\hline
\end{tabular}




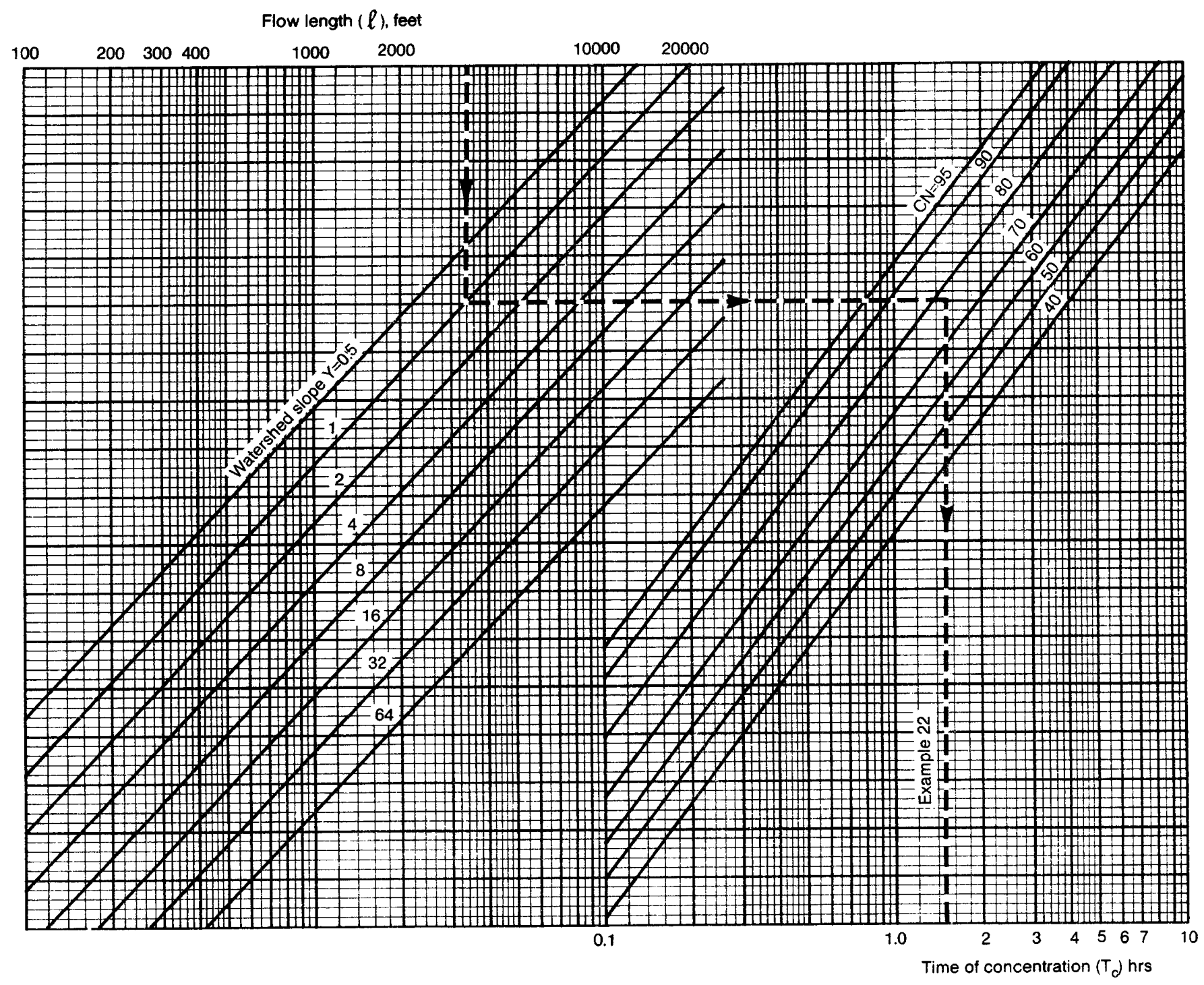

Figure D.1-Time of concentration (TC) nomograph (USDA SCS 1991). 


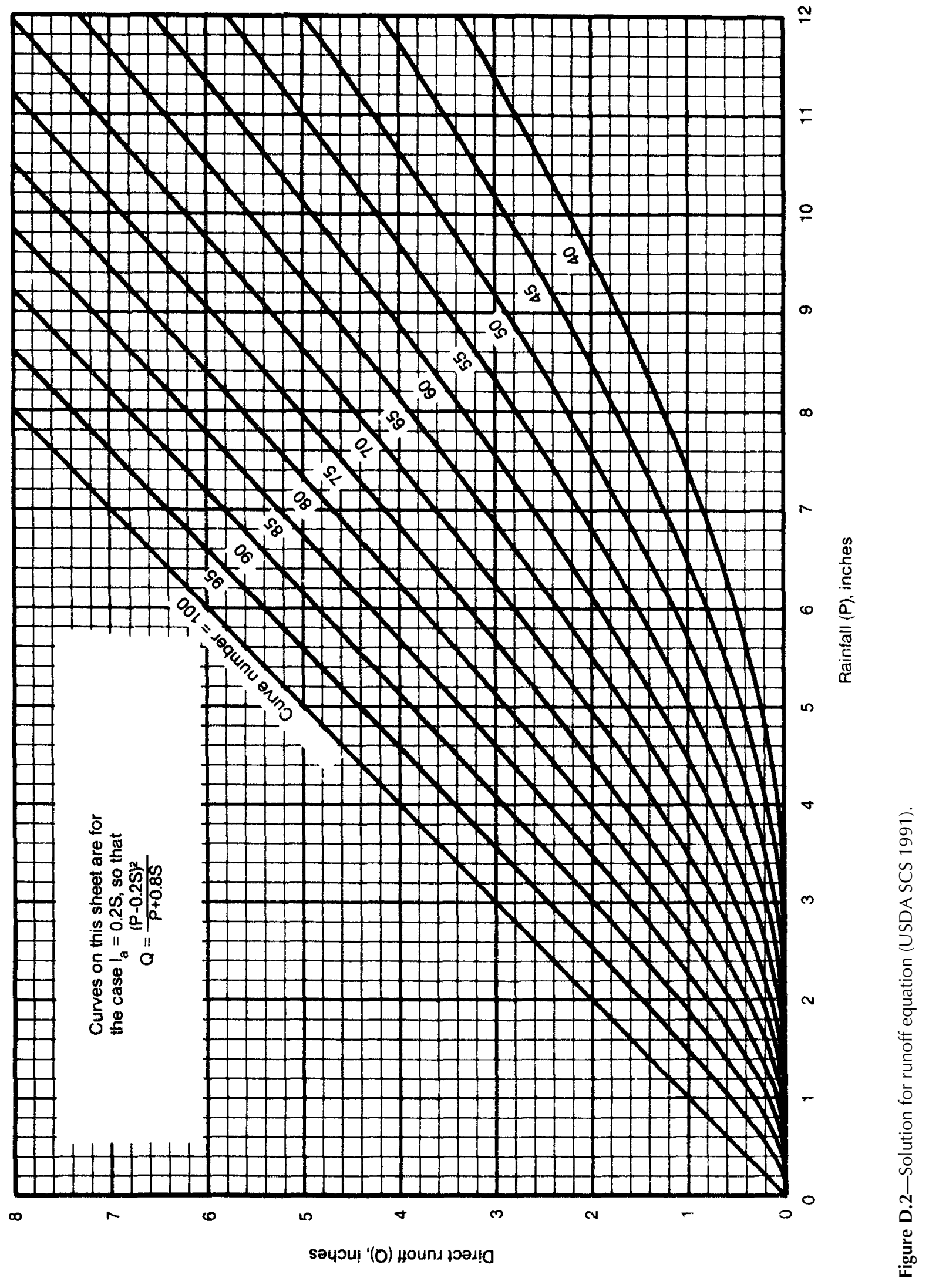




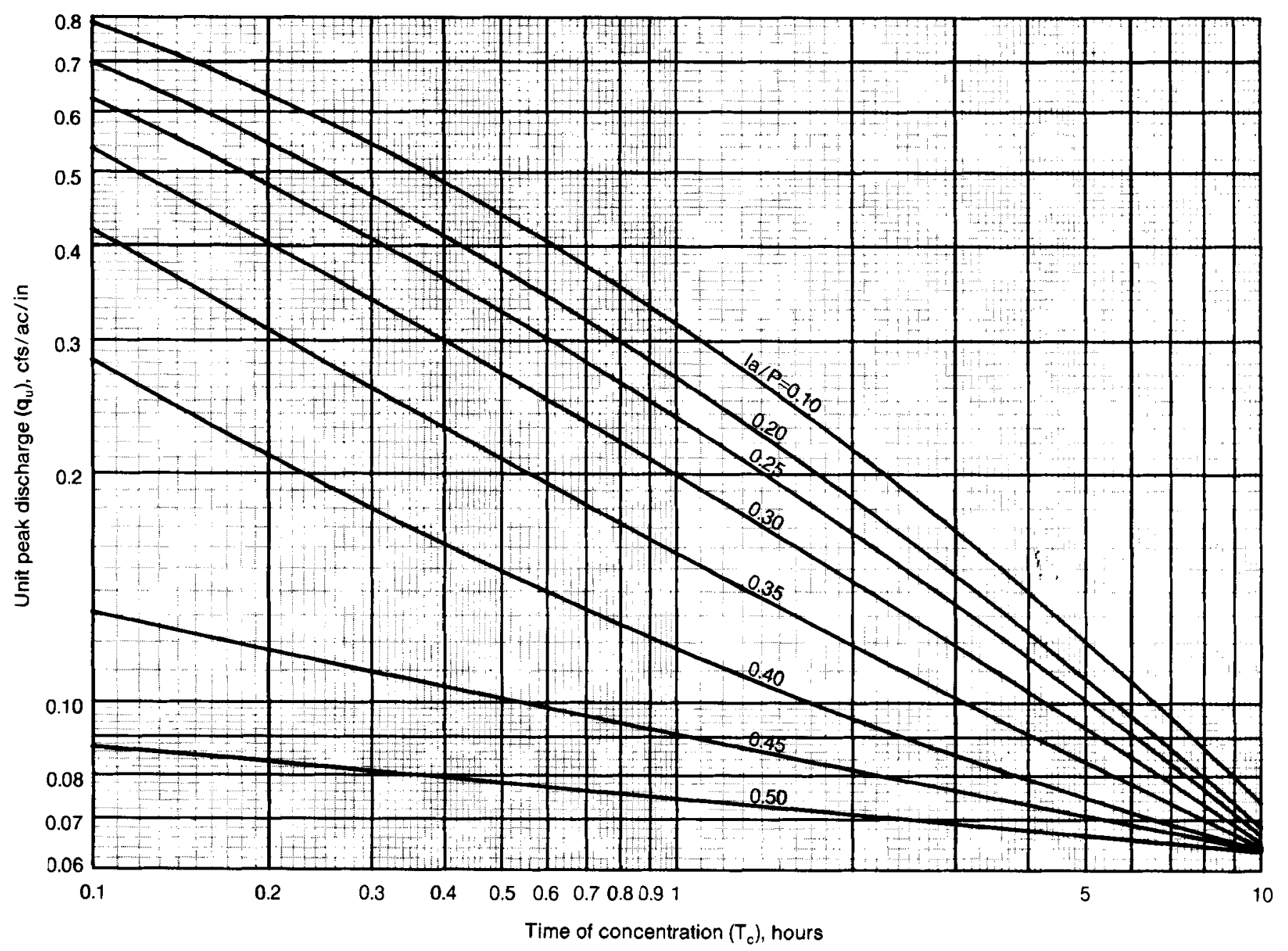

Figure D.3-Unit peak flow (qu) for SCS Type I rainfall distribution (USDA SCS 1991). 


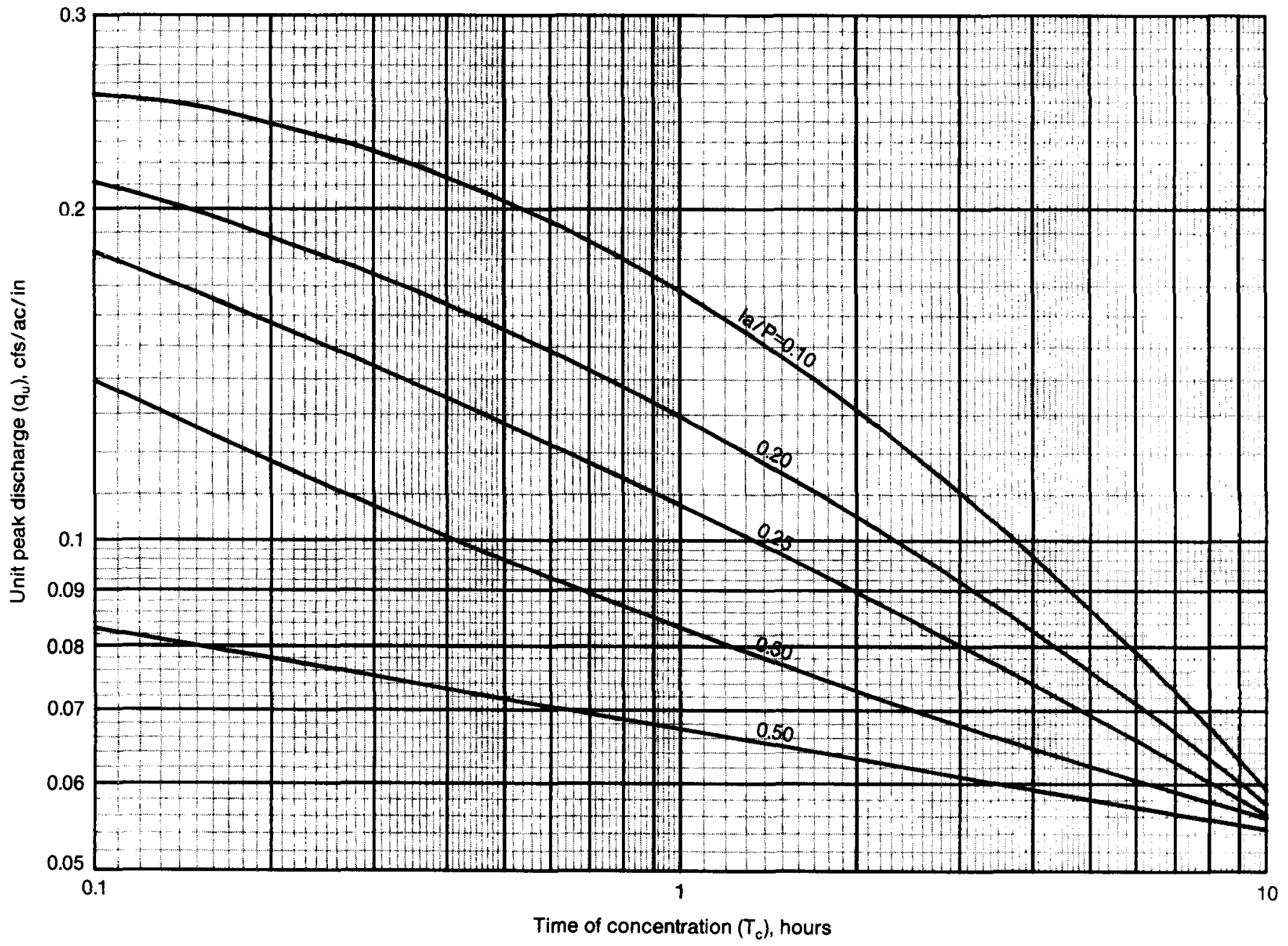

Figure D.4-Unit peak flow (qu) for SCS Type IA rainfall distribution (USDA SCS 1991). 


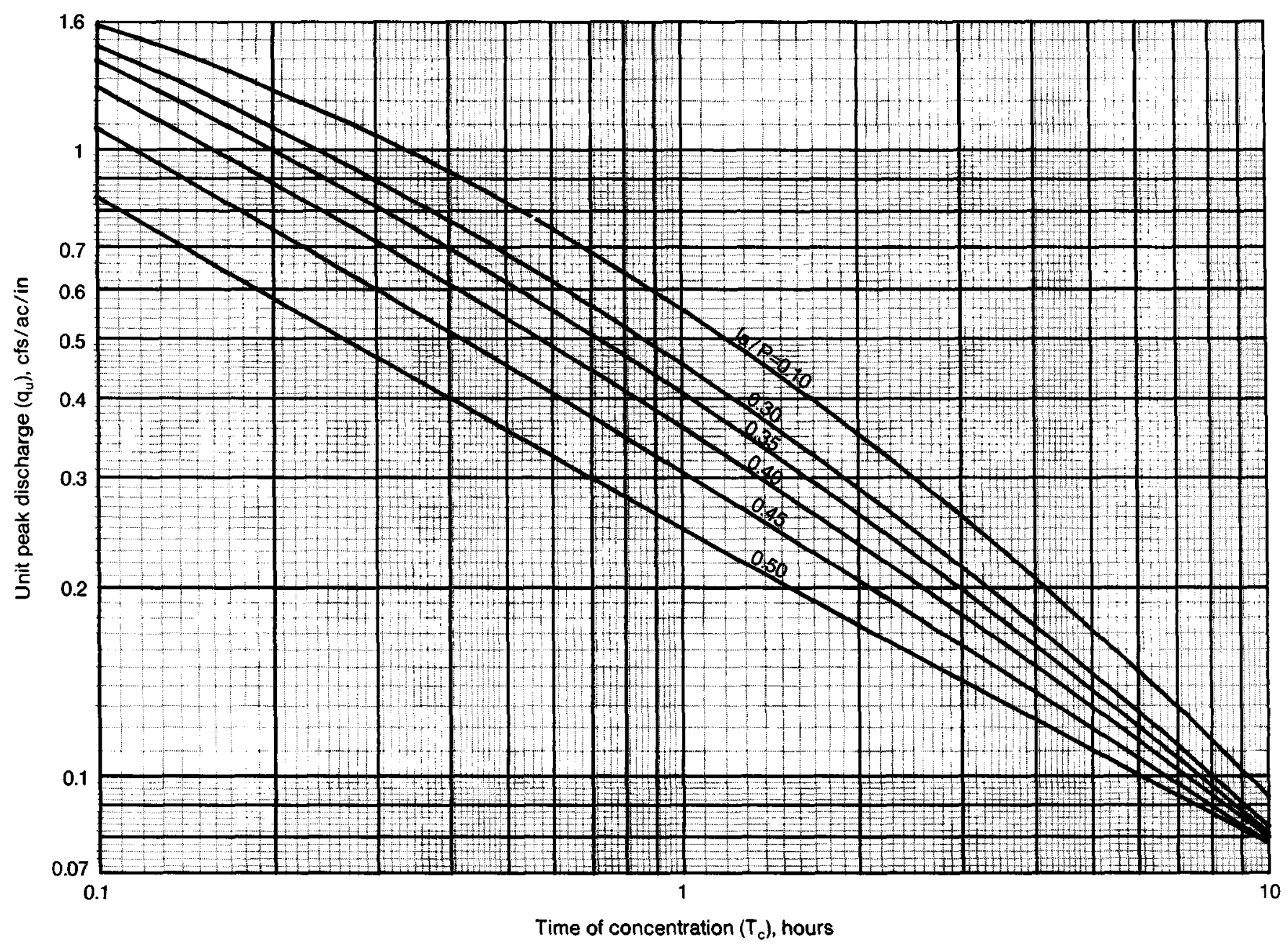

Figure D.5-Unit peak flow (qu) for SCS Type II rainfall distribution (USDA SCS 1991). 


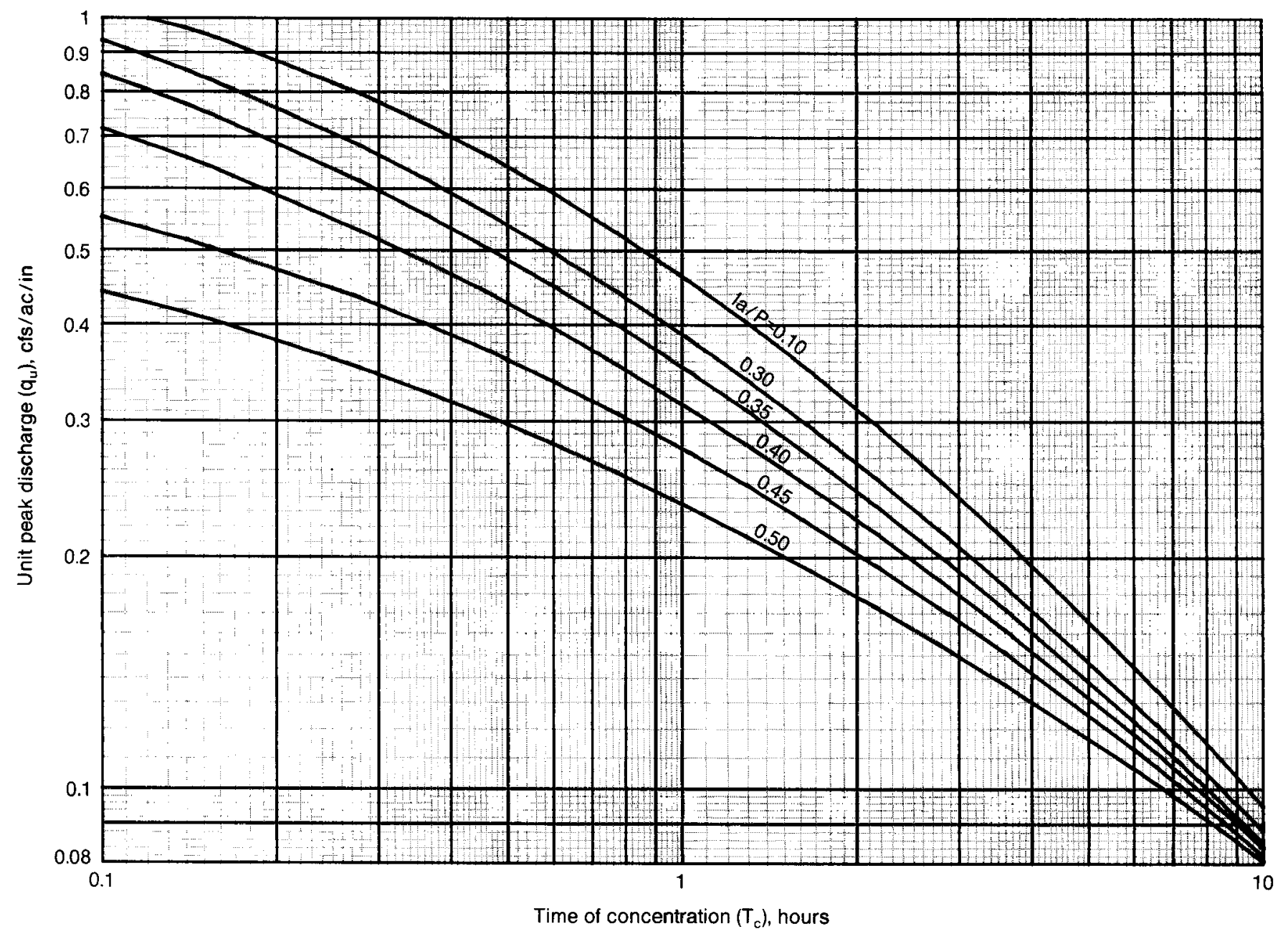

Figure D.6-Unit peak flow (qu) for SCS Type III rainfall distribution (USDA SCS 1991). 


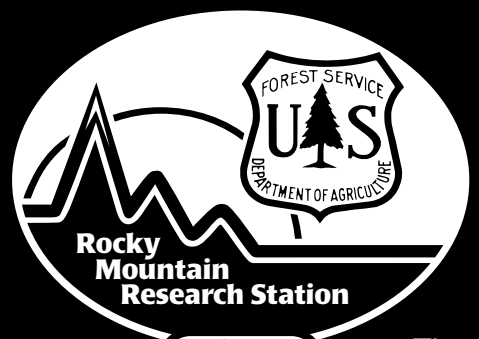

The Rocky Mountain Research Station develops scientific information and technology to improve management, protection, and use of the forests and rangelands. Research is designed to meet the needs of the National Forest managers, Federal and State agencies, public and private organizations, academic institutions, industry, and individuals. Studies accelerate solutions to problems involving ecosystems, range, forests, water, recreation, fire, resource inventory, land reclamation, community sustainability, forest engineering technology, multiple use economics, wildlife and fish habitat, and forest insects and diseases. Studies are conducted cooperatively, and applications may be found worldwide.

\author{
Station Headquarters \\ Rocky Mountain Research Station \\ 240 W Prospect Road \\ Fort Collins, CO 80526
}

(970) $498-1100$

\title{
Research Locations
}

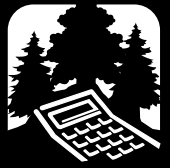

Flagstaff, Arizona

Fort Collins, Colorado

Boise, Idaho

Moscow, Idaho

Bozeman, Montana

Missoula, Montana
Reno, Nevada

Albuquerque, New Mexico

Rapid City, South Dakota

Logan, Utah

Ogden, Utah

Provo, Utah

The U.S. Department of Agriculture (USDA) prohibits discrimination in all its programs and activities on the basis of race, color, national origin, age, disability, and where applicable, sex, marital status, familial status, parental status, religion, sexual orientation, genetic information, political beliefs, reprisal, or because all or part of an individual's income is derived from any public assistance program. (Not all prohibited bases apply to all programs.) Persons with disabilities who require alternative means for communication of program information (Braille, large print, audiotape, etc.) should contact USDA's TARGET Center at (202) 720-2600 (voice and TDD). To file a complaint of discrimination, write to USDA, Director, Office of Civil Rights, 1400 Independence Avenue, S.W., Washington, DC 20250-9410, or call (800) 795-3272 (voice) or (202) 720-6382 (TDD). USDA is an equal opportunity provider and employer. 